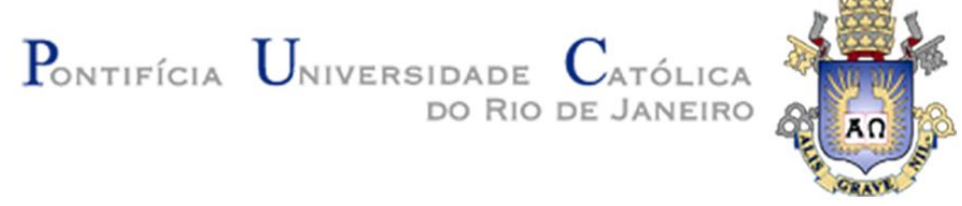

Eunice de Castro e Silva

\begin{abstract}
Usos e Autoria de Recursos Educacionais Digitais: um estudo de caso com os professores do Paraná
\end{abstract}

Tese de Doutorado

Tese apresentada ao Programa de Pós-graduação em Educação da PUC-Rio como requisito para obtenção do grau de Doutora em Educação.

Orientadora: Prof ${ }^{a}$. Magda Pischetola Coorientadora: Profa . Maria João Loureiro

Rio de Janeiro

Fevereiro de 2020 


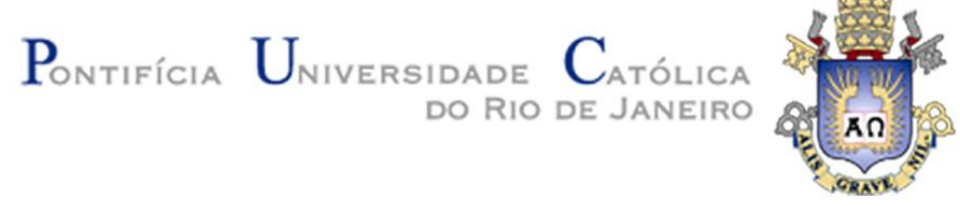

Eunice de Castro e Silva

\title{
Usos e Autoria de Recursos Educacionais \\ Digitais: um estudo de caso com os professores do Paraná
}

Tese apresentada como requisito parcial para obtenção do grau de Doutor pelo Programa de Pós-graduação em Educação do Departamento de Educação do Centro de Teologia e Ciências Humanas da PUC-Rio. Aprovada pela Comissão Examinadora abaixo assinada.

\author{
Profa. Magda Pischetola \\ Orientadora \\ Departamento de Educação - PUC-Rio \\ Profa. Maria João Loureiro \\ Coorientadora \\ Universidade de Aveiro \\ Prof ${ }^{a}$. Giselle Martins dos Santos Ferreira \\ Departamento de Educação - PUC-Rio \\ Prof ${ }^{a}$. Rosália Duarte \\ Departamento de Educação - PUC-Rio \\ Prof. Tel Amiel \\ Universidade de Brasília \\ Prof. Tiago Ribeiro \\ Instituto Nacional de Educação de Surdos
}

Rio de Janeiro, 18 de Fevereiro de 2020 
Todos os direitos reservados. É proibida a reprodução total ou parcial do trabalho sem autorização da universidade, da autora e do orientador.

\section{Eunice de Castro e Silva}

Graduou-se em Licenciatura em Pedagogia na UERJ (Universidade do Estado do Rio de Janeiro) em 2009. Cursou o Mestrado em Educação na PUC-Rio. É pedagoga na Universidade Federal Fluminense e coordenadora de didática do curso de Pedagogia no consórcio CEDERJUENF. Integrante do grupo de pesquisa Formação Docente e Tecnologias (FORTEC), pesquisando educação, didáticas e tecnologias.

Ficha Catalográfica

Silva, Eunice de Castro e

Usos e autoria de recursos educacionais digitais : um estudo de caso com os professores do Paraná / Eunice de Castro e Silva ; orientadora: Magda Pischetola ; coorientadora: Maria João Loureiro. - 2020.

280 f. : il. ; $30 \mathrm{~cm}$

Tese (doutorado)-Pontifícia Universidade Católica do Rio de Janeiro, Departamento de Educação, 2020.

Inclui bibliografia

1. Educação - Teses. 2. Recursos educacionais digitais. 3. Práticas pedagógicas. 4. Autoria docente. 5. TIC. 6. Professores. I. Pischetola, Magda. II. Loureiro, Maria João. III. Pontifícia Universidade Católica do Rio de Janeiro. Departamento de Educação. IV. Título. 
Dedicado à minha avó Maria Elvira (in memorian), que nunca mediu esforços para que eu estudasse, nem orgulho, não importa por onde caminhasse.

Dedico também ao Rone, o vento que mudou o rumo do meu barco - me impulsionou para longe. Obrigada! 


\section{Agradecimentos}

À minha orientadora Magda Pischetola, pela escuta sensível, compartilhamento, estímulo e parceria durante todo o processo desta jornada.

À minha coorientadora Maria João Loureiro, por tudo que me ensinou durante o período em que estive na Universidade de Aveiro, pelo acolhimento e acompanhamento ao meu trabalho. Senti-me em casa, obrigada!

À minha família, pela força, apoio e confiança. Obrigada por todas as vezes que me levantaram quando eu achava que não seria possível.

À minha amiga Keite, que nunca deixou minha peteca cair. Obrigada pelos incentivos, pelas leituras, pela doçura, bom humor e alegria que tornaram esse percurso muito mais leve.

À minha amiga Rosemary, que me acompanha e me incentiva nessa caminhada desde 2008. Eternamente grata por toda a sua ajuda em meus tempos mais difíceis.

À minha equipe de trabalho. Obrigada por segurarem as pontas tantas vezes ao longo destes quatro anos, especialmente nos últimos meses para a conclusão da pesquisa.

À Universidade Federal Fluminense, por ter me concedido licença para o meu período de estudos na Universidade de Aveiro.

Ao grupo de pesquisa FORTEC, por todas as discussões calorosas em nossos encontros. Obrigada pelas trocas, indicações de leituras e avaliações críticas que contribuíram para a elaboração da tese.

Aos professores da PUC, que contribuíram de forma ímpar para a minha construção profissional durante os seis anos que por aqui estive. Um agradecimento especial para a Prof ${ }^{a}$. Rosália, que foi presente em todos os momentos, desde a minha banca de seleção para o mestrado até à banca de defesa do doutorado. Hoje fechamos um ciclo, obrigada.

À PUC-Rio, pela isenção de mensalidades e por toda infraestrutura de apoio no decorrer do curso.

À Secretaria Estadual de Educação do Paraná que aceitou participar da pesquisa.

Aos professores inspiradores que aceitaram conceder entrevistas, muitas vezes após um longo dia de trabalho. Aprendi muito com cada um de vocês e espero que esta pesquisa esteja à altura do valor inestimável do trabalho que vocês constroem em suas escolas e comunidades. 
Aos meus colegas do doutorado, por toda a rede de colaboração que formamos ao longo do curso.

O presente trabalho foi realizado com apoio da Coordenação de Aperfeiçoamento de Pessoal de Nivel Superior - Brasil (CAPES) - Código de Financiamento 001.

A todos que de forma direta ou indiretamente contribuíram para a realização deste trabalho. 


\section{Resumo}

Silva, Eunice de Castro; Pischetola, Magda. Usos e Autoria de Recursos Educacionais Digitais: um estudo de caso com os professores do Paraná. Rio de Janeiro, 2020. 280p. Tese de Doutorado- Departamento de Educação, Pontifícia Universidade Católica do Rio de Janeiro.

O presente estudo teve como foco as práticas pedagógicas com os recursos educacionais digitais (RED) realizadas pelos professores do estado do Paraná. O objetivo geral da investigação foi descrever e compreender se e como os recursos educacionais digitais são utilizados pelos professores para o desenvolvimento de práticas autorais em seus contextos profissionais. Para se compreender o contexto da pesquisa, realizou-se uma revisão bibliográfica sobre os recursos educacionais digitais, autoria docente e competências digitais dos professores. A pesquisa tem como abordagem metodológica um estudo de caso de natureza qualitativa, de cunho descritivo e exploratório e contou com os instrumentos de um survey formado por questões fechadas e uma questão aberta e entrevistas com professores. O questionário teve o alcance de 712 respostas, sendo entrevistados, posteriormente, 6 professores. Para análise, utilizou-se a triangulação dos dados, realizando um tratamento estatístico descritivo e inferencial para os resultados das questões fechadas e a análise de conteúdo com o auxílio do software WebQDA da questão aberta e das entrevistas. Os resultados mostraram que (i) os tipos de usos que os professores fazem dos RED podem variar conforme a formação pedagógica, didática e metodológica do professor, abarcando o RED desde ilustração de conteúdo ao desenvolvimento de atividades educativas contextualizadas; ii) a motivação do docente para sua utilização perpassa pela crença de que o uso dos RED contribui para a elaboração de aulas mais interessantes, promoção de novas oportunidades de aprendizagem para os alunos, aumento da motivação para aprender, o desenvolvimento de práticas e estratégias metodológicas e inserção da escola na cultura digital; (iii) as competências digitais desenvolvidas pelos docentes com o uso do RED são menos complexas, inseridas no letramento informacional e voltadas para o planejamento pedagógico, desenvolvimentos de avaliação e atividades e compartilhamento de conteúdos; (iv) a autoria docente 
precisa estar internalizada na prática do professor para que ele consiga criar práticas mais significativas com os RED, não sendo verificados indícios que o uso dos RED pelos docentes contribui para o surgimento da autoria docente. Acredita-se que este estudo é relevante por contribuir para a ampliação das discussões sobre como os RED são utilizados pelos docentes.

\section{Palavras-chave}

Recursos Educacionais Digitais; práticas pedagógicas; autoria docente; TIC; professores, competências digitais. 


\section{Abstract}

Silva, Eunice de Castro; Pischetola, Magda (Advisor). Uses and Authoring of Digital Educational Resources: a case study with teachers from Paraná. Rio de Janeiro, 2020. 280p. Tese de Doutorado- Departamento de Educação, Pontifícia Universidade Católica do Rio de Janeiro.

This study is focused on pedagogical practices with digital educational resources (DER) carried out by teachers in the state of Paraná. The general aim of the investigation is to describe and understand whether and how digital educational resources are used by teachers to develop authorial practices in their professional contexts. To understand the context of the research, a bibliographic review was carried out about digital educational resources, teacher authorship and digital skills of teachers. The researches have as a methodological approach a case study of qualitative studies, a descriptive and exploratory, and it was adopted the instruments of a survey formed by closed questions and an open question and interviews with teachers. The survey received 712 responses, and 6 teachers were interviewed later. For the analysis, the data triangulation was used, performing a descriptive and inferential statistical treatment for the results of the closed questions and the content analysis with the help of the WebQDA software of the open question and the interviews. The results showed that (i) the types of uses that teachers make of RED can vary according to the pedagogical, didactic and methodological training of the teacher, including RED from content illustration to the development of contextualized educational activities; ii) the teacher's motivation for its uses goes through the belief that the use of RED contributes to the elaboration of more interesting classes, the promotion of new learning opportunities for students and increased motivation to learn, the development of methodological practices and strategies and insertion of the school in the digital culture; (iii) the digital skills developeded by teachers with the use of RED are less complex, within information literacy and focused on pedagogical planning, evaluation developments, and activities and content sharing; (iv) teaching authorship needs to be internalized in the teacher's practice so that he can create more meaningful practices with RED, with no evidence that the use of RED by teachers contributes to the emergence of teaching authorship. It is believed that this 
study is relevant for contributing to the expansion of discussions about how RED is used by teachers.

\section{Keywords}

Digital Educational Resources; pedagogical practices; teaching authorship; ICT; teachers, digital competencies. 


\section{Sumário}

$\begin{array}{ll}\text { 1. Introdução } & 17\end{array}$

$\begin{array}{ll}\text { 1.1. Interesses pessoais ao tema da tese } & 17\end{array}$

1.2. Contextualização do Problema 19

1.3. Objetivos e questões de estudo $\quad 24$

1.4. Opções metodológicas $\quad 25$

1.5. Organização da tese 25

2. Enquadramento do Estudo 27

2.1. Tecendo o background: contexto social e tecnológico 28

2.2. Dos objetos de aprendizagem aos RED 35

2.2.1. Recursos Educacionais Abertos 38

2.2.2. Pesquisas sobre o uso de RED na educação 42

2.3. Perspectivas sobre os processos autorais dos docentes 51

2.3.1. Autoria $\quad 51$

2.3.2. Síntese das pesquisas sobre autoria $\quad 57$

2.3.3. Origens da Autoria Docente 62

2.4. Do conceito de competência digital $\quad 75$

3. Metodologia $\quad 82$

3.1. O fazer ciência e o percurso da pesquisa 82

3.2. Natureza da pesquisa: um estudo de caso 85

3.3. Caracterização dos respondentes ao questionário 91

3.4. Instrumentos de Pesquisa 93

3.4.1. Questionário 95

3.4.2. Entrevistas 102

3.4.2.1 Concepção do roteiro 104

3.5. Procedimentos para Análise de Dados 105

3.5.1. Análise Estatística e Inferencial 105

3.5.2. Análise de Conteúdo 108

3.5.2.1 Procedimentos adotados na análise de conteúdo 110 
4. Descrição dos dados 116

4.1. Questionário on-line aplicado aos professores do Paraná 116

4.1.1. Bloco "Perfil dos respondentes" 117

4.1.2. Bloco "Contexto profissional e tecnológico" 120

4.1.3. Bloco "Recursos Educacionais Digitais" 130

4.1.4 Análise de correlação entre os construtos 143

4.2. Análise de conteúdo da questão aberta 147

4.2.1. Aprendizagem 149

4.2.2. Desenvolvimento profissional docente 157

4.2.3. Inserção na Cultura Digital 162

4.3. Análise de conteúdo das entrevistas 166

4.3.1. Concepções sobre autoria 169

4.3.2. Percurso para a autoria docente 185

4.3.3. Relações da autoria docente com as tecnologias 192

5. Bricolagens instituídas na pesquisa: autoria e práticas docentes com RED

5.1. Utilização dos RED por professores em seus contextos profissionais

5.2. Motivação dos professores para a utilização dos RED 212

5.3. Relação entre as competências digitais e os usos dos RED 218

5.4. Desenvolvimento de práticas autorais do professor e o uso de RED

Apêndice

Apêndice I - Termo de Consentimento Livre e Esclarecido

Apêndice II - Questionário

Apêndice III - Estatística Descritiva 250

Apêndice IV - Análises Bivariadas 259

Apêndice V - Protocolo para o Grupo Focal On-line 272

Apêndice VI - Roteiro para GFO após avaliação 276

Apêndice VII - Adaptação do Roteiro para Entrevista 280 


\section{Lista de tabelas}

Tabela 1 - Mapeamento de Repositório de RED

Tabela 2 - Docentes participantes do grupo focal

Tabela 3 - Exemplo de formação de construto

Tabela 4 - Tecnologias acessíveis para os professores na instituição em que atuam

Tabela 5A - Recursos Educacionais mais utilizados 132

Tabela 5B - Recursos Educacionais mais utilizados 133

Tabela 6 - Descritores para análise da entrevista 167 


\section{Lista de quadros}

Quadro 1 - Síntese da metotodologia empregada 90

Quadro 2 - Revisão de literatura para a construção do questionário $\quad 98$

Quadro 3 - Síntese do questionário 101

Quadro 4 - Sistema de Categorias da questão aberta 112

Quadro 5 - Sistema de Categorias das entrevistas $\quad 114$

Quadro 6 - Correlação entre os construtos 144

Quadro 7 - Teste de significância entre os construtos 147

Quadro 8 - Referências por categorias 149

Quadro 9 - Referências por categorias na análise das entrevistas $\quad 168$

Quadro 10 - Tipos de usos dos RED 212 


\section{Lista de gráficos}

Gráfico 1 - Faixa salarial dos professores $\quad 117$

Gráfico 2 - Segmento de atuação dos professores 118

Gráfico 3 - Área do conhecimento em que é docente 119

Gráfico 4 - Maior titulação de formação 119

Gráfico 5 - Frequência de uso de tecnologias no cotidiano 123

Gráfico 6A - Práticas e atividades tecnológicas 124

Gráfico 6B - Atividades pedagógicas com o uso das tecnologias $\quad 127$

Gráfico 7 - Relação entre o contexto de trabalho e tecnologia 129

Gráfico 8 - Atitude em relação aos RED 136

Gráfico 9 - Práticas de compartilhamento de RED 139

Gráfico 10 - Práticas autorais com RED 140

Gráfico 11 - Correlação entre os construtos 147 


\section{Lista de figuras}

Figura 1 - Inserção dos Recursos Educacionais Abertos 38

Figura 2 - Formação da Autoria Docente $\quad 72$

Figura 3 - Quadro DigCompEdu $\quad 79$

Figura 4 - Desenho da Pesquisa 84

Figura 5 - Critérios adotados para a escolha dos participantes para o grupo focal 92

Figura 6 - Triangulação de instrumentos $\quad 95$

Figura 7 - Procedimentos para a análise de conteúdo 115

Figura 8 - Grupos de competências digitais 126

Figura 9 - Grupo de práticas pedagógicas com TIC 128

Figura 10 - Fases de práticas autorais com RED 143

Figura 11 - Nuvem de palavras - questão aberta 148

Figura 12 - Resultados da categoria aprendizagem 155

Figura 13 - Resultados da categoria desenvolvimento profissional 161

Figura 14 - Resultados da categoria inserção na cultura digital $\quad 166$

Figura 15 - Nuvem de palavras - entrevistas 168

Figura 16 - Resultados da categoria "Concepções sobre a Autoria" 184

Figura 17 - Resultados da categoria "Percursos para a Autoria Docente" 192

Figura 18 - Resultados da categoria "Relações da Autoria Docente com as Tecnologias" 


\section{Introdução}

Este capítulo apresenta a introdução da tese, traçando um diálogo entre os interesses pessoais que me motivaram a pesquisar o tema dos recursos educacionais digitais e autoria docente, situando este estudo no contexto das pesquisas e políticas educacionais que perpassam esse tema e apresentando os objetivos e questões de estudo que foram respondidos ao longo da tese.

\section{1}

\section{Interesses pessoais ao tema da tese.}

Independentemente da modalidade ou do nível de ensino em que o profissional da educação atue, ele irá se deparar, pelo menos algumas vezes, com os recursos educacionais disponibilizados na internet. Foi dessa forma que durante minha trajetória profissional precisei pesquisar, adaptar, consumir e criar recursos educacionais que pudessem ter o potencial de ressignificar e ampliar as experiências de aprendizagens que eu propunha em minha prática, como descrevo seguidamente.

Durante o ano de 2012, como orientadora pedagógica responsável pela formação continuada de professores do primeiro e segundo segmento do ensino fundamental, diversas vezes, ao fazer o planejamento das reuniões pedagógicas, pesquisava vídeos, textos, imagens, entre outras mídias, que, ao meu julgamento, ajudariam os professores a ampliar a perspectiva do tema debatido. Também como docente em turmas de cursos de licenciatura na Universidade Estadual Norte Fluminense (UENF) era comum levar para sala de aula Recursos Educacionais Digitais (RED). Ainda como coordenadora da disciplina de didática de um curso a distância, ao elaborar o desenho didático no ambiente virtual de aprendizagem (AVA), adaptei, empreguei, criei e reproduzi diferentes RED.

Em qualquer um dos contextos acima referidos, o uso feito dos RED era isento de maiores questionamentos. Guiava-me a assunção de que, se os RED 
estavam disponibilizados na internet, o professor estaria livre para utilizá-los e modificar da forma que julgasse mais apropriada. Editar vídeos para que pudessem ser trabalhados pedagogicamente, modificar textos adequando-os ao contexto educativo, mixar imagens criando uma nova para que pudesse ser utilizada em um AVA, entre outros, eram práticas realizadas sem que houvesse uma reflexão sobre esses usos e seus impactos no processo de ensino e de aprendizagem.

Ponderar sobre tais práticas levou-me a indagar meu processo formativo em tecnologias digitais e a educação. Através da troca com meus pares percebi que desenvolver uma prática didática explorando as tecnologias da informação e comunicação (TIC), em maior ou menor grau, relaciona- se com a utilização de RED. Assim, por que debatemos tão pouco sobre os RED se eles são utilizados tão abertamente? Os cursos de formação de professores ao discutir sobre a integração das TIC estariam abordando o tema dos RED e os outros recursos que são abertos?

Em um primeiro momento, percebi que se eu quisesse compreender e problematizar o uso que professores fazem dos RED precisava entender como a informação se dissemina pela rede, que relações se estabelecem entre o uso dos RED, a cultura digital e a circulação de ideias. Posteriormente, conceitos como a lógica da ação conectiva (BENNETT; SEGERBERG, 2013) e os commons (LESSIG, 2001) me levaram a questionar como o consumo, a adaptação e a criação de RED se concatenavam com a forma com a qual as pessoas constroem bens comuns, assim como tudo isso se conectava ao movimento da educação aberta, somando-se ao conceito de remix, como configuração da cultura digital (MANOVICH, 2005; LEMOS, 2009).

Tendo em conta o exposto, propus-me aprofundar o assunto e desenvolver um projeto de doutoramento na área. Nas seções seguintes abordo o problema do estudo, procuro clarificar o conceito de RED e problematizo e situo o objeto de estudo da investigação: o uso e autoria de RED por professores do estado do Paraná. 


\section{2}

\section{Contextualização do Problema}

Formar professores para as demandas do século XXI, especialmente no que se refere às práticas pedagógicas com as TIC, está presente nas pautas das pesquisas e programas educacionais dos últimos anos. O documento da Organização das Nacões Unidas para a Educação, a Ciência e Cultura (UNESCO) (2014) “Tecnologias para a transformação da Educação", direcionado aos países latinoamericanos, defende que a tecnologia ocupa um importante espaço no processo de repensar o currículo, a didática e o processo de ensino e de aprendizagem, visando atender às demandas de uma sociedade pautada cultural, social e economicamente na informação e no conhecimento. No intuito de atender a tais diretrizes, é esperado que os docentes tenham competências profissionais que lhes permitam se apropriar das potencialidades comunicacionais e pedagógicas das TIC gerando mais e melhores oportunidades de aprendizagem (ibidem).

Para compreendermos as competências ou saberes que os docentes devem mobilizar ao atuarem com as TIC, recorremos novamente à UNESCO (2009), mas dessa vez ao documento "Padrões de Competências em TIC para professores" que explicita, dentre outros saberes, que os professores devem ser capazes de:

- Elaborar materiais on-line que apoiem o melhor entendimento dos alunos sobre os principais conceitos e sua aplicação no mundo real;

- Operar vários softwares livres apropriados à área da disciplina;

- Usar as TIC para acessar e compartilhar recursos de apoio às suas atividades e a seu próprio desenvolvimento profissional;

- Elaborar materiais on-line e atividades que envolvam os alunos na solução colaborativa de problemas, pesquisas ou criação artística;

- Usar as TIC para participar nas comunidades profissionais, compartilhar e discutir as melhores práticas de ensino.

Também no contexto brasileiro, as TIC têm um importante papel no desenvolvimento da qualidade da educação. Por exemplo, dentre as competências gerais da Base Nacional Comum Curricular, destacamos a referente a "utilizar as 
tecnologias digitais de comunicação e informação de forma crítica, significativa, reflexiva e ética nas diversas práticas do cotidiano (incluindo as escolares) ao se comunicar, acessar e disseminar informações, produzir conhecimentos e resolver problemas" (BRASIL, 2016). No atual Plano Nacional de Educação (2014 - 2024) percebemos o que é esperado a partir e através das práticas pedagógicas com as TIC. Destacamos algumas das estratégias apresentadas no PNE que se relacionam com as tecnologias:

5.4) fomentar o desenvolvimento de tecnologias educacionais e de práticas pedagógicas inovadoras que assegurem a alfabetização (...)

7.12) incentivar o desenvolvimento, selecionar, certificar e divulgar tecnologias para a educação infantil, o ensino fundamental e o ensino médio e incentivar práticas pedagógicas inovadoras que assegurem a melhoria do fluxo escolar e a aprendizagem, assegurada a diversidade de métodos e propostas pedagógicas, com preferência para softwares livres e recursos educacionais abertos $(\ldots)$

16.4) ampliar e consolidar portal eletrônico para subsidiar a atuação dos professores e professoras da educação básica, disponibilizando gratuitamente materiais didáticos $\mathrm{e}$ pedagógicos suplementares, inclusive aqueles em formato acessível (BRASIL, 2014).

De uma forma geral, tanto as recomendações da UNESCO como as diretrizes nos documentos brasileiros nos permitem inferir que ao utilizar as TIC na prática pedagógica, é esperado que o professor:

- Produza e compartilhe recursos educacionais;

- Desenvolva tecnologias pedagógicas e práticas inovadoras;

- Compartilhe práticas educacionais inovadoras em comunidades profissionais;

- Encontre e utilize materiais didáticos e pedagógicos em portais eletrônicos disponíveis gratuitamente;

- Use software livres;

- Manipule RED.

Analisando as atitudes e habilidades que são esperadas pelos professores percebemos que existe uma grande demanda dos sistemas educativos por um 
docente que desenvolva conteúdos e recursos educacionais, que participe de comunidades de práticas compartilhando experiências inovadoras e recursos educacionais e que saiba encontrar os recursos e ampliar seus conhecimentos e habilidades com as TIC. Pretto (2012) defende que é necessário pensarmos no professor para além de um ator de processos estabelecidos fora de sua realidade, mas como tendo autoria. Assim, os professores "além de atores no sistema educacional passam a ser autores dos processos e, dessa forma, passam a promover enfaticamente a criação" (p. 97). Nesse sentido, considerando o que se espera de um docente ao integrar as TIC em contextos educativos, percebemos que existe um gap entre as expectativas descritas nos documentos de políticas públicas brasileiras e nas recomendações da UNESCO e a garantia de formação adequada, ambiente e estrutura para que essas práticas com os RED possam ser concebidas.

Compreendemos o conceito de RED a partir de Ramos (2012), que os descreve como entidades digitais que são produzidas especificamente para dar suporte ao ensino e à aprendizagem. Os RED incluem recursos variados, como um jogo educativo, um programa informático, um vídeo, um tutorial, um blog, uma apresentação, entre outros. Para o autor, o mais importante é que o recurso esteja em suporte digital e que permita aos professores e alunos uma experiência de aprendizagem que potencialize àquela que poderia ser desenvolvida com meios tradicionais de ensino.

São inúmeras as iniciativas de repositórios de RED que podem ser encontrados na internet (SANTOS, 2012; ROSSINI, 2010; SANTANA, 2012) e, para elucidar e problematizar o uso que professores tem feito destes recursos, apoiamo-nos em alguns resultados da pesquisa TIC Educação ${ }^{1}$.

$\mathrm{Na}$ edição de 2016 verificou-se que os professores utilizam recursos educacionais digitais abertos ou Recursos Educacionais Abertos (REA) em suas práticas educacionais. O estudo mostrou que os recursos mais pesquisados e utilizados pelos professores na preparação de aulas foram questões para avaliações $\left(1^{\circ}\right)$, textos variados $\left(2^{\circ}\right)$, imagens, ilustrações e figuras $\left(3^{\circ}\right)$, notícias $\left(4^{\circ}\right)$, filmes e

\footnotetext{
${ }^{1}$ Essa pesquisa vem sendo realizada anualmente, desde 2010, pelo Comitê Gestor da Internet no Brasil (CGI) e tem o objetivo de identificar os usos e apropriações das TIC nas escolas brasileiras por meio da prática pedagógica e da gestão escolar (CETIC, 2013).
} 
animações $\left(5^{\circ}\right)$. Com relação às plataformas de acessos aos recursos foram apontados os sites de escolas, blogs de professores e o Portal do Professor do MEC. Observou-se, ainda, que apenas $17 \%$ dos professores utilizaram os recursos educacionais sem realizar nenhum tipo de modificação ou alteração no conteúdo, enquanto que $87 \%$ afirmaram ter baixado ou copiado o conteúdo e realizado alterações e $82 \%$ afirmaram já ter criado um conteúdo novo combinando vários materiais obtidos na internet (CETIC, 2017). Tal constatação abre espaço para problematizar as práticas autorais realizadas pelos professores, ou seja, a adaptação, a recombinação ou o remix de RED, suas dinâmicas de produção e compartilhamento.

Na edição de 2017, verificou-se que o acesso aos recursos educacionais digitais de qualidade foi apontado pelos diretores escolares e coordenadores como o principal benefício oferecido pelas tecnologias, seguido pela adoção de novos métodos de ensino. A pesquia aponta ainda que as tecnologias promoveram maior colaboração entre os professores de uma mesma escola e também passaram a ter contato com educadores e especialistas de outras instituições.

Os dados coletados com os professores mostraram que 93\% têm uma percepção favorável aos recursos educacionais digitais e 87\% acreditam que as TIC promovem a adoção de novos métodos de ensino. A pesquisa ainda apontou que 96\% dos professores de escola pública fizeram uso de algum tipo de recurso encontrado na internet para o planejamento de atividades educacionais e que $74 \%$ dos docentes admitem que a tecnologia facilita a colaboração entre os pares.

Os resultados das últimas edições da pesquisa têm evidenciado o crescimento do desenvolvimento de atividades educacionais com os recursos educacionais digitais, deixando uma lacuna para a compreensão de quais seriam os principais usos e práticas pedagógicas criadas com estes recursos.

A contextualização do problema de pesquisa evidencia que existem conhecimentos, habilidades, perspectivas e demandas para a atuação do professor com as TIC; além disso, encontram-se diferentes repositórios de recursos digitais disponibilizados para os professores; e por fim, existem os usos autorais que professores realizam a partir e através desses recursos em seu cotidiano e prática 
pedagógica. Tais elementos nos impõem o desafio de compreender as relações entre as práticas autorais de professores, a tecnologia e os RED.

O interesse por pesquisas voltadas para os RED tem direcionado a atenção de muitos pesquisadores. No campo da educação percebe-se um crescimento, nos últimos anos, dos estudos de doutoramento que tinham como temática os RED e/ou REA, embora ainda seja muito incipiente.

Através de levantamento no banco de teses da Coordenação de Aperfeiçoamento do Ensino Superior (CAPES), que abordou o período de 2009 a 2019, e utilizando-se as palavras-chaves "recursos educacional" e "recursos educacionais digitais", foram encontradas seis teses no campo da educação que versavam sobre essa temática.

Os estudos de Rossini (2015), Amaral (2017), Shimazaki (2017) e Jacques (2017) se voltaram para a sistematização do processo de contrução de RED e de práticas educacionais com estes recursos por professores e alunos no ensino superior. Nessas pesquisas foram desenvolvidas estratégias que privilegiavam o processo autoral do professor nos contextos específicos de cada pesquisa.

Já as pesquisas de Fialho (2016) e Vagula (2014) focam na formação de professores e suas relações com o RED. Fialho (2016) buscou analisar as contribuições dos REA para a formação inicial e continuada dos professores de química, tais como o aprimoramento da prática pedagógica, na cultura do compartilhamento de experiências e o estímulo para produção de outros REA. Na pesquisa de Vagula (2014) procurou-se, por meio da formação continuada de professores, perceber o impacto dos REA em relação às práticas educacionas dos docentes, como o enriquecimento do processo de coaprendizagem e cocriação.

Delineia-se neste contexto um crescimento da demanda para a utilização dos RED nos processos de ensino e aprendizagem e, ao mesmo tempo, uma maior visibilidade das práticas educacionais que estão sendo desenvolvidas pelos docentes. Contudo, ainda são poucos os estudos brasileiros que se debruçaram a compreender os tipos de práticas desenvolvidas pelos professores com os RED. 


\section{3}

\section{Objetivos e questões de estudo}

As pesquisas acima citadas evidenciam que os RED são utilizados e produzidos pelos professores no ensino superior e na educação básica. No entanto, percebe-se nesses estudos que o processo de criação e a utilização desses RED ocorrem durante a pesquisa. É através do contato com o pesquisador e da inserção na pesquisa com abordagem de pesquisa-ação ou pesquisa-formação que os professores-sujeitos passam a criar os RED e a utilizá-los em seu contexto educacional.

Nesse sentido, defendemos que ainda faltam elementos que nos levem a compreender os usos que os professores já fazem dos RED, especialmente quando questionamos se os professores que participaram de tais estudos conseguem direcionar para seus contextos profissionais os conhecimentos e competências agenciados durante o processo de formação de cada um desses estudos.

Destarte, os resultados da pesquisa TIC Educação (CETIC, 2017) apontam que os professores utilizam os RED em seus contextos. Contudo, percebemos um gap com respeito ao aprofundamento que nos leve a compreender os tipos de RED utilizados pelos professores e os tipos de práticas pedagógicas autorais construídas através destes usos.

Este estudo se insere na necessidade de buscar compreender os usos e práticas dos professores com os RED e suas motivações. Acrescenta-se também o entendimento de que as competências digitais se associam com as formas de uso dos RED. Deste modo, partimos do pressuposto de que se um professor constrói práticas educacionais em que a tecnologia tem um papel importante, ele poderá estar mais inclinado a criar, utilizar e compartilhar recursos educacionais digitais.

Diante do exposto, definimos como objetivo deste estudo descrever $e$ compreender se e como os recursos educacionais digitais são utilizados pelos professores para o desenvolvimento de práticas autorais em seus contextos profissionais. 
O objetivo da pesquisa foi desdobrado em algumas questões de estudo que foram respondidas no decorrer da pesquisa, a saber:

- Como são utilizados os recursos educacionais digitais (RED) por professores nos seus contextos profissionais?

- O que motiva os professores a usar RED nos seus contextos profissionais?

- Que correlação existe entre o nível de competência digital dos professores e os tipos ou modos de utilização de RED?

- Em que medida o uso de RED em rede contribui para o desenvolvimento de práticas autorais do professor?

\section{4}

\section{Opções metodológicas}

Esta pesquisa, por suas características e encaminhamentos, constitui-se em um estudo qualitativo, do tipo estudo de caso. Como será explicado posteriormente, o desenho metodológico deste estudo foi realizado a partir dos resultados de uma primeira investida para encontrar os sujeitos da pesquisa

Após uma extensa revisão de bibliografia e delineamento dos objetivos e questões de estudo foi realizado um mapeamento dos repositórios de recursos educacionais digitais brasileiros com objetivo de chegar aos professores que já utilizavam os RED em suas práticas. Foram contatados 31 repositórios de RED aos quais foi apresentado o estudo, sendo que apenas o repositório de RED da Secretaria Estadual de Educação do Paraná (SEED/PR) concordou em participar. É nesse sentido que defendemos que essa pesquisa se tornou um estudo de caso 


\section{5}

\section{Organização da tese}

Esta tese se estrutura em 6 capítulos. No capítulo 1 é apresentada a tese a partir de sua contextualização no campo de estudo, seu objetivo e questões de estudo.

No capítulo 2, "enquadramento do estudo", é realizada uma extensa revisão bibliográfica, buscando apresentar o contexto social e tecnológico em que inserem as práticas dos professores com os RED; mapear os resultados das principais pesquisas sobre os usos que os professores fazem com os RED; compreender as pesquisas já realizadas sobre a autoria docente, propondo elementos que podem se relacionar com as origens da autoria docente; e por fim, apresentar o conceito de competências digitais e suas relações com as práticas pedagógicas construídas pelos professores.

No capítulo 3, "metodologia", apresentamos de forma atenta cada etapa da pesquisa, as escolhas metodológicas realizadas, o processo de construção dos instrumentos utilizados para a coleta de dados e os métodos de análise empregados para cada instrumento e cada fase da pesquisa.

No capítulo 4, "descrição e análise dos dados", expomos os dados provenientes do questionário e das entrevistas. Buscamos no decorrer da descrição realizar um diálogo entre os resultados e os aspectos teóricos levantados na revisão de literatura, buscando situar os achados frente às diferentes pesquisas realizadas anteriormente na temática dos RED e práticas educacionais dos professores.

No capítulo 5, "bricolagens instituídas na pesquisa: autorias e práticas docentes com RED”, procuramos realizar a triangulação dos dados desenvolvidos no capítulo 4, visando responder as questões de estudos propostas na introdução deste trabalho.

Por fim, no capítulo 6, "considerações conclusivas", apresentamos uma proposta de usos e autorias de RED com base em práticas autorais e culturais, os limites da pesquisa e perspectivas futuras de estudo. 


\section{2.}

\section{Enquadramento do estudo}

Estar imerso em um ambiente de cultura digital significa que em diferentes medidas nossas relações sociais são mediadas pelos artefatos tecnológicos presentes em diferentes espaços no nosso cotidiano. A tecnologia está presente desde atividades simples como fazer uma fotografia de férias em família até o desenvolvimento de cidades inteligentes, cibersegurança ou criptomoedas.

Relativamente à qualidade do uso das TIC, permeia entre muitos dos que usam a tecnologia a ideia de que ela não é boa nem má, pois sua qualidade depende do uso que cada um decide fazer dela, concebendo-a como neutra. Também no campo da educação, especialmente na formulação das políticas públicas, prevalece a imagem da tecnologia como ferramenta para o alcance de objetivos educacionais, pautados em sua maioria em discurso cartesiano e racional (HEINSFELD, 2018).

Contrariamente ao exposto, temos como posição que as práticas sociais que desenvolvemos com a tecnologia não são neutras nem descontextualizadas. Já na década de 60, McLuhan (2007) nos alertava que a tecnologia produz uma mudança em termos de relacionamentos sociais que supera o objetivo ou a mensagem dela. Nesse sentido, independente do uso "bom" ou "mal" que possa ser feito da tecnologia, a sua simples presença em um ambiente já produz modificações culturais e sociais nesse meio, sendo improvável considerá-la como neutra. Nas palavras do autor, "os efeitos da tecnologia não ocorrem aos níveis das opiniões e dos conceitos: eles se manifestam nas relações entre os sentidos e nas estruturas da percepção" (MCLUHAN, 2007, p.34).

Tendo em conta o acima referido, um professor ao utilizar a tecnologia em sala de aula não faz um uso neutro, pois, ainda que não tenha plena consciência, esse uso é contextualizado e culturalizado. Partindo desse princípio, ao pesquisar sobre as práticas autorais de professores com recursos educacionais digitais (RED), apontamos a necessidade de discutir e tentar compreender o contexto cultural em 
que estão inseridas as tecnologias, a escola, os professores e suas práticas educacionais com os RED.

Assim, nas seções seguintes apresentamos uma discussão sobre o contexto social do uso da tecnologia e dos RED, em particular, na educação; as principais pesquisas sobre RED e recursos educacionais abertos (REA) em diferentes modalidades e segmentos de ensino; a autoria docente, buscando compreender sua origem e elemento motivadores; e sobre as competências digitais dos professores e suas possíveis relações com as práticas autoriais com os RED.

\section{1}

\section{Tecendo o background: contexto social e tecnológico}

Tecer o background significa conceber que o contexto faz parte do objeto e está em constante interação com os sujeitos e com o pesquisador, formando um sistema. Morin (2000) defende que um fenômeno só é inteligível se for possível restituí-lo em suas condições históricas e sociológicas, ou seja, se for pensado complexamente. Por sua vez, Melucci (2005) fala da importância de compreendermos a pesquisa como um fazer situado que depende das interações interdependentes entre o contexto, sujeitos e observador, formando assim o objeto. Para o autor, é impossível tratarmos um único elemento sem considerar as suas relações com os outros. É sob a perspectiva de compreender o objeto que defendemos a necessidade de refletir sobre a rede contextual em que essa pesquisa é tecida.

Para nós, são indissociáveis enquanto objeto, as atividades que professores realizam com os RED do contexto em que estes atuam. Nesse sentido, conceber o contexto como um sistema complexo é o primeiro passo para que possamos interpretar os liames que se estabelecem entre a autoria, compartilhamento e adaptação de RED e as práticas de exploração destes recursos em contexto educativo. $\mathrm{O}$ contexto em que esta pesquisa acontece passa pelo digital e pelo entendimento da sociedade como rede. 
O conceito de Sociedade em Rede não se estabelece a partir das tecnologias que emergiram na segunda metade do século XX. Essa configuração é inerente à inserção do ser humano na realidade social, sendo tão antiga como o fenômeno humano, visto que tem íntima relação com a formação de uma identidade política e cultural. (PISCHETOLA, 2016). Contudo, defendemos que os avanços comunicacionais e informacionais que presenciamos nas últimas décadas alteraram os modos e a velocidade com que as informações vêm sendo distribuídas socialmente. As alterações sociais ocasionadas pela dinâmica da rede não são encaradas de modo consensual, chegando muitas vezes a serem polarizadas entre aqueles que têm uma visão otimista de como as tecnologias alteraram as relações sociais, culturais e econômicas e os que possuem uma visão apocalíptica sobre tais modificações (ECO, 1979).

Dentre os autores com uma visão integrada ou otimista, Castells (1999) explica que o desenvolvimento econômico pautado nas TIC no final do século XX corroborou para o surgimento de uma nova estrutura social. Segundo o autor, as TIC constituíram o mundo em redes globais, que modificaram de forma substancial a operação e os resultados dos processos produtivos de experiência, poder e cultura. Aprofundando essa noção, Ugarte (2008), em um estudo sobre a lógica social da rede mediada pelas TIC, a identifica como uma rede distribuída. Para o autor, se quisermos compreender os novos fenômenos sociais e políticos, devemos entender como a informação se dissemina pela rede. Para tanto, ele parte da ideia da rede distribuída em que considera os pontos que unem os segmentos como pessoas e instituições e as conexões como as relações entre as pessoas. Visto sob essa ótica, nenhum ponto depende exclusivamente de ninguém para poder levar a qualquer outro sua mensagem, ou seja, se configura como uma rede de iguais.

Os moldes de como a informação se dissemina pela rede distribuída ficam evidentes quando consideramos as práticas culturais que são produzidas, consumidas e compartilhadas na internet. As produções humanas não se limitam apenas à rede, mas a extrapolam trazendo para a cidade suas demandas, suas lutas, suas construções, sua cultura. Bennett e Segerberg (2013) mostram como através de uma lógica da ação conectiva, as pessoas têm se movimentado em coletivos em prol de causas comuns, culminando em movimento de ocupações em cidades de 
todo o mundo. Além disso, é pela lógica da ação conectiva que as pessoas constroem bens comuns e compartilham ideias, conhecida como produção por pares. Nesse modo de produção, os indivíduos atuam como um ativismo cooperativo que, segundo os autores, se dá pela satisfação pessoal que cada ativista tem em participar na construção de um bem comum. Como exemplos, temos a Wikipedia, Wikileaks, o movimento Software Livre, os protestos organizados via rede social, dentre tantas outras práticas sócio culturais que são construídas no cotidiano via mídias digitais.

Atento para as mudanças e implicações sociais e culturais que poderiam derivar dos avanços tecnológicos, Manovich (2001) procura compreender as características ou princípios dessa "nova" mídia. O autor centra a discussão explicando por que a revolução causada pela "nova mídia" é diferente de todas as outras. Segundo ele, diferentemente de outros momentos, com os adventos tecnológicos comunicacionais e informacionais, a produção cultural tem a possibilidade de ser mediada pelas TIC em todo o seu processo (produção, distribuição e comunicação), afetando todos os estágios envolvidos na comunicação (aquisição, manipulação, armazenamento e distribuição) e os diferentes tipos de linguagens (textos, imagens e sons). A partir dessa análise, Manovich (2001) identifica cinco princípios que contribuem para a velocidade das produções culturais no digital: (i) a representação numérica - códigos binários; (ii) a modularidade - objetos que compõem uma mesma mídia, mas que podem ser trabalhados independentemente; (iii) automatização - os dois princípios anteriores permitem a automação de várias operações que envolvem o digital (inteligência artificial, programação e etc), (iv) a variabilidade ou plasticidade - no sentido de usuários modificarem a mídia por meio de remixagem criando diferentes versões; e (v) a transcodificação cultural ou a forma em que hardware e software interagem e afetam as práticas sociais e culturais - modificando a lógica cultural do digital, resultando em uma cultura computacional transcodificada ou uma mistura de significações humanas e computacionais.

Posteriormente, Lemos (2009), ao conceituar a cultura digital, explica que existem leis que são a base dos processos culturais mediados pelas TIC. Entre tais leis ou princípios, destacamos o princípio da liberação do polo emissor que 
possibilitou a qualquer indivíduo produzir e a emitir informações. Contudo, para que essas informações possam ser transmitidas é preciso que elas sejam compartilhadas e conectadas em rede. Para o autor, o uso das redes e das TIC potencializam a criação de vínculos sociais locais e planetários, perfazendo esse o princípio da conexão generalizada. Trazemos também para o diálogo o princípio de reconfiguração da indústria cultural massiva e da sociedade industrial. Este é uma recombinação que, segundo Lemos (2002, p. 41), "acolhe processos bidirecionais, abertos, nos quais prevalece a liberação da emissão sob diversos formatos e modulações, e uma conexão generalizada e planetária por redes telemáticas".

Os princípios da variabilidade e da transcodificação cultural de Manovich e o princípio da liberação do polo de emissão levantado por Lemos podem ser considerados a base da crença de que as tecnologias digitais têm a capacidade de potencializar processos autorais de usuários "digitalmente letrados" (JENKINS, 2006). Essa perspectiva contribuiu para o crescimento da confiança de que a cultura digital pode estimular criações colaborativas, considerando a internet como um ambiente de livre produção cultural.

Segundo Lessig (2005), a internet oportuna a muitos a participação no processo de construção de cultura, diferentemente do modelo da indústria cultural promovida no século XX. Benkler (2015), no livro The Wealth of Networks, realizou um estudo sobre a economia da informação em rede que emerge no século XXI. O autor fez um contraponto entre as formas de produção na indústria cultural e as produções culturais baseadas nas redes informacionais, defendendo que a segunda lógica está pautada em um sistema de produção mais participativo e transparente, ou seja, de liberdade cultural. Esse modelo trouxe algumas consequências para a sociedade, entre tais que:

a economia da informação em rede influencia na capacidade de indivíduos e grupos de participar na produção das ferramentas culturais e nos marcos de compreensão e discursos humanos. Igualmente influencia na maneira em que, como indivíduos e como membros de círculos sociais e políticos, interagimos com a cultura, e através dela, entre nós mesmos. Finalmente faz com que a cultura seja mais transparente para seus habitantes e que o processo de produção 
cultural seja mais participativo, no sentido que mais pessoas pertencentes a dita cultura possam participar ativamente de sua criação. Estamos assistindo ao possível nascimento de uma nova cultura popular, produzida segundo um modelo da cultura tradicional ativamente habitada, no lugar de estar sendo apenas destinada ao consumo passivo das massas. Através destas características gemelares - transparência e participação - a economia da informação em rede cria também um maior espaço para a avaliação crítica dos materiais e ferramentas culturais. A prática de produzir cultura nos converte a todos em leitores, espectadores e ouvintes mais sofisticados, assim como criadores mais comprometidos ${ }^{2}$. (BENKLER, 2015, p. 321, tradução nossa).

As palavras de Benkler sustentam a ideia de que a rede tem o potencial de promover produções culturais mais transparentes e participativas, conclamando a colaborações entre pares.

Contudo, ao mesmo tempo em que os avanços tecnológicos criam oportunidades de participação e de práticas culturais, temos assistido que esse mesmo avanço alimenta o crescimento do controle e manipulação da informação e da opinião pública, revestidos por princípios de livre circulação de ideias e direito de escolha. Um exemplo da dualidade dessa nova configuração da tecnologia e da internet é o Big Data ou o imenso acúmulo de dados produzido por e sobre pessoas, coisas e suas interações, se comportando como um fenômeno cultural e tecnológico, com discursos e usos utópicos e distópicos. Segundo Boyd e Crawford (2012), do lado utópico ele é encarado como uma poderosa ferramenta que poderia contribuir para a solução de diversos males sociais. Destarte, no ponto de vista distópico, o

\footnotetext{
2 "la economía de la información en red influye en la capacidad de los individuos y los grupos de participar en la producción de las herramientas culturales y los marcos de comprensión y discurso humanos. Igualmente influye en la manera en que, como individuos y como miembros de círculos sociales y políticos, interactuamos con la cultura y, a través de ella, entre nosotros. Finalmente hace que la cultura sea más transparente para sus habitantes y que el proceso de producción cultural sea más participativo, en el sentido de que más personas pertenecientes a dicha cultura puedan participar activamente en su creación. Estamos asistiendo al posible nacimiento de una nueva cultura popular, producida según el modelo de la cultura tradicional y activamente habitada, en lugar de estar destinada al consumo pasivo de las masas. A través de esas características gemelas, transparencia y participación, la economía de la información en red crea también un mayor espacio para la evaluación crítica de los materiales y herramientas culturales. La práctica de producir cultura nos convierte a todos en lectores, espectadores y oyentes más sofisticados, así como en creadores más comprometidos" (BENKLER, 2015, p. 321)
} 
controle do Big Data poderia desencadear invasões de privacidade, diminuição de liberdades cívicas, manipulação da opinião pública, influenciar campanhas eleitorais, entre outros.

De acordo com Lessig (2005), embora a internet propicie a participação no processo de construção de cultura, diferentemente do modelo da indústria cultural promovida no século XX, permanece uma disputa pela manutenção, restrição e controle dos direitos de conteúdo, justificando, inclusive, sanções legais mais severas do que as praticadas no século passado. Para o autor, "jamais houve em nossa história um período em que tanto da nossa "cultura" tinha um "dono" como atualmente. E nunca antes houve um período em que a concentração de poder para controlar os usos da cultura foi tão inquestionavelmente aceita como o é atualmente" (LESSIG, 2005, p. 11).

As discussões sobre as utopias e distopias dos avanços tecnológicos ocorrem também no campo da Educação. Selwyn (2017) discute sobre a importância de olhar criticamente para os modos em que a educação está se apropriando da tecnologia. $\mathrm{O}$ autor alerta que a tecnologia educacional tem se tornado um negócio multibilionário para o fornecimento de ações e práticas educacionais locais e tais usos desencadeiam em questões de organização e distribuição de poder, controle, conflitos e resistências, em detrimento de uma verdadeira democratização de acesso à informação. Assim, as pesquisas que permeiam a educação e a tecnologia precisam refletir sobre a natureza política da tecnologia como não neutra, levando em conta o conflito social sobre a distribuição do poder. (SELWYN, 2017).

Wessels (2015) assume que as interfaces digitais criam novas maneiras de se relacionar na sociedade, mas isso também implica no surgimento de novos status que são formados e controlados pelas TIC, contribuindo para determinar a inclusão e exclusão de cidadãos, afetando sua participação na vida social e econômica. Nesse cenário, o acesso à tecnologia digital é a característica chave da dinâmica de inclusão e exclusão. Para Ragnedda e Murchert (2013), a dinâmica da desigualdade digital se refere ao modo em que várias combinações de níveis de acesso e competências digitais com situações de exclusão social resultam em diferentes níveis de experiências individuais de acesso a bens materiais, sociais e digitais. Assim, em vez de democratizar, a tecnologia pode aprofundar as diferenças 
educacionais, culturais e sociais entre os indivíduos, mas de uma forma mais grave estará disfarçada de um discurso otimista em que derruba barreiras e possibilita ao usuário livre criação de conhecimento e emancipação.

Buscando um equilíbrio entre as potencialidades das TIC na educação e ao mesmo tempo estando consciente das desigualdades que esta tecnologia poderia causar, nos situamos entre aqueles que acreditam no potencial da rede. Não por defender que a rede seja transparente ou que naturalmente promova uma cultura participativa, mas por acreditar que também está presente nela uma cultura que resiste e defende a liberdade da autoria, como é o movimento de abertura.

De acordo com Wiley (2014), o movimento de abertura começou nas universidades com a crença e a luta para que a educação e o acesso ao conhecimento fossem concebidos como bens públicos. Inspirados no movimento do Software Livre, Wiley e outros pesquisadores começaram um projeto para o licenciamento e disseminação de conteúdos abertos, visando compartilhar criações intelectuais mais facilmente (GARCIA-PENALVO et al., 2010). Com o desenvolvimento das tecnologias informacionais e da ampliação de alcance dos processos comunicacionais nas redes, o movimento de abertura se ramificou originando outros movimentos, tais como: Open Software, Open Hardware, Open Government Open Acess, Open Science, Open Data, dentre outros.

Pensar o movimento de abertura implica entender a rede como espaço público, ou seja, o conhecimento produzido pode ser compartilhado como bem comum. Em tese, esse conceito implica que o conhecimento pode ser disseminado e compartilhado livremente na Internet para o benefício da sociedade. Para entender a importância de discutir o movimento de abertura nos diferentes espaços, podemos citar por exemplo o caso de materiais didáticos que são criados debaixo de leis de direito autoral tão cerceadas. Segundo Branco (2007), no contexto educativo existe um impasse entre criação, direitos de conteúdos e o livre acesso à educação. Nesse cenário o direito à educação e o acesso democrático ao conhecimento estariam em segundo plano com relação à manutenção dos direitos autorais que, especificamente no Brasil, é uma das mais restritivas do mundo. 
Benkler (2015) ressalta a inevitabilidade de lutarmos para que os recursos necessários para as produções em rede sejam regulados como bens públicos, se apresentando como alternativa aos recursos "disponíveis" na rede sendo, contudo, fechados e endereçados à lógica do mercado. Nesse sentido, acreditamos que essas práticas culturais demandam por um livre acesso para que

qualquer pessoa que use o instrumental amplamente disponível possa utilizar mais ou menos o que desejar do universo cultural existente, cortá-lo, usá-lo, remixá-lo e apropriar-se dele - seja para expressar sua admiração ou repugnância, adoção de certas imagens ou completa rejeição ${ }^{3}$ (BENKLER, 2015, p. 323, tradução nossa).

Trazendo esse conceito para a educação pensamos que esta seria a base para que professores com diferentes níveis de competências digitais possam co-criar, adaptar e compartilhar práticas educacionais e materiais pedagógicos, rompendo com dinâmicas de consumo e reprodução de conteúdos educacionais.

É nesse contexto, com suas dimensões utópicas e distópicas, que investigamos as práticas educacionais e autorais que professores criam através e a partir dos RED. Compreendemos que eles estão situados e culturalizados em um tempo específico, sendo um dos nós no emaranhado das redes.

\section{2}

\section{Dos objetos de aprendizagem aos RED}

Embora o uso de recursos educacionais tenha se expandido majoritariamente após o advento da web 2.0, seu emprego na educação vem desde a década de 1980 e teve, ao passar dos anos, diferentes propostas metodológicas de produção e pedagógicas, quanto aos seus usos. Ramos et al. (2012) explicam que nos últimos 30 anos os usos dos recursos passaram por fases que são diferenciadas e reconhecidas por refletirem o seu contexto histórico específico, assim como o

\footnotetext{
3 "cualquier persona que use el instrumental ampliamente disponible pueda tomar más o menos lo que dese del universo cultural existente, cortarlo, pegarlo, mezclarlo y apropiárselo — sea para expresar su adoración o su repugnancia, su adopción de ciertas imágenes o su rechaz" (BENKLER, 2015, p. 323).
} 
desenvolvimento de novas TIC. Segundo os autores, essas etapas são denominadas como perspectiva da informática, evoluindo para uma perspectiva de conteúdos, e, por fim, chegando a uma perspectiva de aprendizagem e comunidade.

Os autores definem a perspectiva da informática como a fase em que os recursos educacionais caracterizavam-se pelos usos de linguagens e ferramentas de programação. Nessa fase, verificavam-se algumas dificuldades no conhecimento sobre educação, aprendizagem e currículo, assim como também eram notórias as dificuldades dos professores em explorarem os recursos em sala de aula devido às dificuldades com o domínio da ferramenta e com a transposição didática para um novo contexto educativo.

Posteriormente, iniciou-se a perspectiva dos conteúdos, sendo caracterizada pelo desenvolvimento de várias estratégias que visavam a superação das dificuldades enfrentadas na perspectiva informática. Entre as estratégias definidas estavam o enfoque aos conteúdos curriculares estruturados, tendo a tecnologia um papel transmissor ou um formato de manual escolar digital.

Por fim, temos a perspectiva da aprendizagem e da comunidade. Ramos et al. (2012) explicam que nessa fase a tecnologia passa a ser concebida como uma rica ferramenta no processo de aprendizagem dos alunos, apresentando uma elevada participação nesse processo. Como resultado, surgiram inúmeros programas de informática educativa, programas de animação, simulação e modelação matemática. Embora tenham sido recebidos com entusiasmo pelas escolas, os autores argumentam que foi valorizado nesses recursos o lado informacional da tecnologia, refletindo em uma visão informacional da aprendizagem.

Outra vertente sobre a evolução dos recursos educacionais é apresentada por Wiley (2000). Em um primeiro momento, o autor concebe os recursos educacionais como objetos de aprendizagem (OA), definindo-os como qualquer recurso digital que pode ser reutilizado como suporte para a aprendizagem, abordando duas características principais: ser reutilizado em diferentes contextos educacionais e ser compatível a diferentes plataformas e tecnologias. Na visão do autor, os OA são um tipo de aprendizagem mediada por computador que se fundamentam no paradigma 
da ciência computacional orientada ao objeto e priorizando a criação de componentes que podem ser reutilizados. Já Leffa (2016) considera que um objeto de aprendizagem pode ser definido como objetos mínimos de aprendizagem, sendo parte de um elemento maior. Nessa perspectiva, seria possível a combinação desses objetos para se produzir experiências de aprendizagem.

Lane e McAndrew (2010) apresentam que a finalidade dos objetos de aprendizagem era criar experiências de aprendizagem mais efetivas em que fosse possível a configuração e reconfiguração de diferentes elementos (atividades, conteúdos, ferramentas). A ideia era que a criação e o compartilhamento de ferramentas e conteúdos pudessem ser reutilizadas em diferentes contextos, enriquecendo as experiências dos estudantes.

Para compreender esse conceito podemos tomar a metáfora do LEGO. Diferente da peça de um quebra-cabeça que se encaixa apenas em seu elemento original, as peças do LEGO permitem diferentes combinações formando novos elementos ou experiências, produzindo resultados e aprendizagens diferentes de outrora. Por outra ótica, considerando a ideia de que a metáfora do LEGO poderia sugerir que qualquer peça ou OA poderia se encaixar em qualquer proposta de aprendizagem, Willey (2000) propõe a ideia do OA como um átomo, visto que estão implícitas restrições de combinações de objetos, assim como há restrições nas interações de diferentes tipos de átomos.

Com o tempo foram ocorrendo mudanças. De acordo com Leffa (2016), a reusabilidade dos OA foi substituída pelo redirecionamento adaptativo, ou o seu reaproveitamento com a introdução de mudanças. Outro elemento de diferenciação e evolução foi proposto por Recker et al. (2005) ao defender que o termo objeto de aprendizagem daria margens para definições ambíguas, como se a aprendizagem fosse apenas uma propriedade do objeto. Assim, propôs que o termo "recursos educacionais" sugere que a aprendizagem é uma rede constituída pelos recursos, pessoas, práticas e valores que estão implícitos no contexto. Também Hadjerrouit (2012) sustenta o uso do termo recursos de aprendizagem e que esses recursos estão associados com o interesse pedagógico de influenciar o processo de ensino e de aprendizagem, promovendo uma intercessão entre conteúdo, pedagogia e tecnologia. 
Em relação aos avanços dos recursos educacionais abertos com respeito aos objetos de aprendizagem, Lane e McAndrew (2010) explicam que a definição dos REA não adota explicitamente a noção de padronização ou modularidade, mas abarca cursos completos, textos, testes, softwares, módulos, áudios e vídeos.

Diante das perspectivas abordadas, defendemos a adoção do termo RED por acreditar que este se aproxima mais da ideia relacional que se imbrica entre a educação e as práticas culturais digitais de professores e alunos. Ressalta-se aqui a importância de, para além de pensarmos a concepção dos RED, compreendermos o seu papel principal no processo de ensino e de aprendizagem. Nesse sentido, entendemos os RED como os recursos que possibilitam experiências educativas que não poderiam ser vivenciadas com o uso restrito de metodologias analógicas e tradicionais.

Discutida a diferenciação entre objetos de aprendizagem e recursos educacionais, julgamos essencial pontuarmos a conceituação dos recursos educacionais abertos, visto que embora não seja o foco central da pesquisa é uma ramificação importante dos recursos educacionais e se imbrica durante todo o percurso da investigação.

\subsection{1}

\section{Recursos Educacionais Abertos}

O movimento dos recursos educacionais abertos (REA) se insere no movimento de abertura, como podemos observar na figura a seguir:

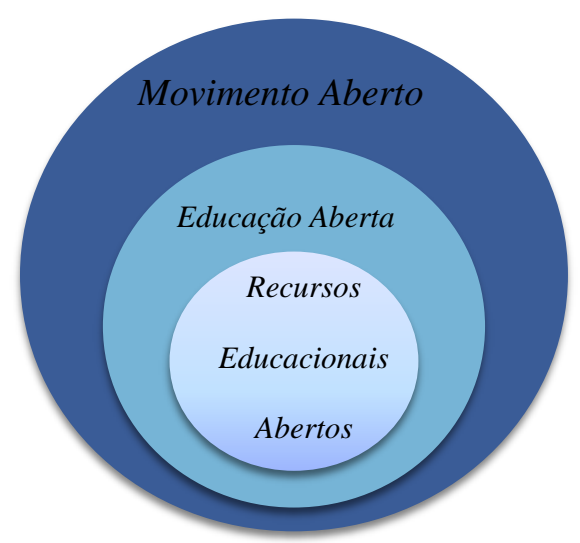

Figura 1 - Inserção dos Recursos Educacionais Abertos. Fonte: Elaboração própria 
A figura 1 nos mostra que os REA estão inseridos em uma filosofia de abertura que atravessa a educação. Segundo Amiel (2012), a Educação Aberta (EA) é uma tentativa de buscar alternativas sustentáveis para algumas das barreiras ao acesso de uma educação de qualidade. Embora o sentido da "abertura" não dependa exclusivamente de aspectos tecnológicos, é através da configuração da lógica de comunicação em rede que a Educação Aberta alcança maior visibilidade e espaço político. $\mathrm{O}$ autor aponta que a viabilidade da EA é suscetível às condições materiais, envolvendo instituições, sistemas e recursos educacionais disponíveis. Ao mesmo tempo depende de práticas abertas e de uma cultura que promova o compartilhamento e a transparência, como fora aludido por Benkler.

É no contexto do movimento da Educação Aberta que se insere os REA. De acordo com Butcher (2011), REA se refere a qualquer material de suporte à educação que pode ser acessado, reutilizado, modificado e compartilhado livremente. O documento explica que os REA são parte de um processo de licenciamento aberto em que conteúdos, especialmente os digitalizados, podem ser copiados e compartilhados sem a necessidade de permissão do autor, possibilitando que tais atividades ocorram dentro de um marco legal mais flexível que o de todos os direitos reservados. Nesse sentido, os recursos podem ser reutilizados e adaptados para contextos educacionais diferentes, ao mesmo tempo em que possibilitam aos autores terem o seu trabalho reconhecido (BUTCHER, 2011).

Hilton III et al. (2010) explicam que o conceito de abertura de um recurso educacional não se reduz a simplesmente ser ou não aberto, mas defendem que existem graus de aberturas de dimensões legais e técnicas. Com respeito aos aspectos legais, os autores apresentam um framework com os tipos de licenças e usos que podem estar implicados nos REA, identificados como 5 'R' de abertura, sendo estes:

- Reter: direito de fazer, possuir e controlar cópias de conteúdo.

- Reusar: o nível mais básico de abertura. Permite que as pessoas façam uso do recurso sem modificações. 
- Redistribuir: além de usar o recurso, as pessoas podem compartilhar cópias dos trabalhos com terceiros.

- Revisar: é permitido adaptações, modificações, traduções e modificações na forma em que o trabalho é apresentado.

- Remixar: criar um novo recurso a partir de combinações do primeiro recurso com outros.

Considerando que um recurso tenha licença aberta, Hilton III et al. (2010) apontam que existem outros fatores que influenciam a abertura, como fatores técnicos que interferem nos graus de abertura de um recurso, como pode ser encontrado no framework $\mathrm{ALMS}^{4}$ desenvolvido por Wiley (2009). Assim, garantir que um REA tenha tanto os 5 'R' como o ALMS é o primeiro passo para que um recurso reflita a filosofia da educação aberta. Ainda poderíamos adicionar a facilidade em encontrar repositórios em que os recursos são disponibilizados, assim como saber avaliar sua qualidade pedagógica.

Com relação a esses aspectos, Atenas e Havermann (2014) realizaram um estudo em que se propuseram a fazer uma revisão de literatura sobre a qualidade dos repositórios de REA. A partir de seu levantamento, os autores definem que a motivação e a cultura subjacentes à criação dos repositórios podem ser categorizadas em busca, compartilhamento, reuso e colaboração. Nesse sentido, os repositórios devem prover "apoio aos educadores na busca de conteúdos, compartilhamento de recursos próprios, reuso, adaptação e avaliação de materiais

\footnotetext{
${ }^{4}$ Acess to editing to? - O REA precisa estar em software de edição que trabalhe em diferentes sistemas operacionais, necessitando que sejam livres ou gratuitos.

Level of expertise required to revise or remix - é necessário que o criador de um REA pense em softwares de fácil utilização no momento de produção de um recurso. Desse modo, o REA terá mais chances de ser adaptado e remixado por outros usuários.

Meaningfully editable - os autores citam o caso de documentos scaneados e transformados em PDF que não podem ser editados. Nesse sentido, defendem que os autores de REA precisam se certificar que o formato do arquivo permita a edição.

Source-file access - se refere à necessidade dos usuários terem acesso aos arquivos fontes de um REA, no caso de arquivos em que a extensão final não é editável como, por exemplo, os arquivos em flash.
} 
desenvolvidos por ou em colaboração com outros membros da comunidade 5 " (ATENAS e HAVERMANN, 2015, p. 5, tradução nossa).

De acordo com os autores existe um gap entre os incentivos profissionais oferecidos pelas instituições educacionais e a cultura de compartilhar e remixar recursos abertamente. Nesse sentido, formar professores para novas práticas educativas é um trabalho contínuo que requer soluções que envolvem mudanças culturais e maior acesso às tecnologias, oferecendo suporte para que essas práticas sejam possibilitadas. Além disso, os pesquisadores assumem que reusar e remixar materiais produzidos por outros professores pode contribuir para fomentar a criatividade de educadores, encorajando-os a refletir sobre o modo como eles ensinam a colaboração na comunidade escolar para melhorar e adaptar recursos.

O aspecto colaborativo no uso dos REA também foi levantado por Littlejohn e Hood (2017) através de uma pesquisa em que se propuseram compreender como os educadores construíam conhecimento e expandiam suas práticas com o uso de recursos abertos. A pesquisa demonstrou que os educadores aprendiam sobre os REA a partir do ambiente, resultando de interações com colegas que também usavam REA, ou seja, "oportunidades de aprendizagem situadas no cotidiano". Nesse sentido, eles destacam a importância da socialização e diálogo como nas situações em que professores aprendiam novas práticas a partir do envolvimento em discussões com colegas sobre um recurso específico. Para os autores, a motivação para o uso de REA também é resultado da prática em uma relação entre o fazer e o pensar. Sendo assim, a aprendizagem ou a formação dos professores era mais efetiva quando estava integrada em um contexto de prática onde desenvolver práticas educacionais abertas ajudava professores a produzirem conhecimento com recursos abertos. A pesquisa também mostrou que a avaliação dos recursos engloba a aprendizagem que ocorre quando os educadores refletem e avaliam o seu engajamento com REA e o impacto desse envolvimento em sua prática.

Cabe ressaltar aqui que os REA, como qualquer outro recurso, não são por si só agentes de mudança. São as práticas que os professores realizam e as trocas

\footnotetext{
5 “to support educators in searching for content, sharing their own resources, reusing and evaluating materials, and adapting materials made by or in collaboration with other members of the community" (ATENAS e HAVERMANN, 2015, p. 5).
} 
com seus pares que possibilitam novas abordagens educacionais com o uso dos recursos. No entanto, para que isso seja possível é necessário que os professores se percebam enquanto autores que produzem sentidos em suas práticas pedagógicas com os RED. Nesse aspecto, entender o professor como um sujeito autoral e praticante da cultura digital é requisito para que docentes possam se apropriar dos recursos educacionais de forma a construir novas práticas pedagógicas.

\subsection{2}

Pesquisas sobre os usos de recursos educacionais digitais na educação

Nos últimos anos têm sido desenvolvidas diferentes pesquisas sobre a utilização dos RED. Ramos et al. (2012) defendem que estes precisam estar atrelados a uma proposta em que seja possível explorar as características da tecnologia, promovendo processos de aprendizagem. Nesse ínterim, espera-se que alterações no contexto educativo, como novos objetivos e metodologias possam ser designados por "recursos educacionais potencialmente inovadores" (RAMOS et al., 2012, p.20).

Nesse tópico nos deteremos a discutir sobre as investigações que perpassam as práticas educacionais de professores com os RED. Para tanto, foi realizado um levantamento bibliográfico, sendo utilizado como critérios de pesquisas as palavras chaves "professores", "recursos educacionais digitais" ou "recursos educacionais abertos", "prática pedagógica" ou prática educacional" e "autoria". Além disso foi considerado também um corte temporal dos estudos publicados entre os anos de 2009 a 2019.

Após a leitura dos resumos dos estudos, elegendo os que eram pertinentes para a presente pesquisa e a partir da leitura posterior dos artigos completos, nos foi possível identificar que as pesquisas levantadas caminhavam em três tendências: (i) as práticas pedagógicas com os RED ou com os REA; (ii) os fatores motivacionais que influenciam o uso de RED ou de REA pelos professores; (iii) e o impacto do uso de RED ou de REA na prática educacional. 


\section{As práticas pedagógicas com o uso de RED e REA}

As pesquisas que se debruçam na temática do uso de RED e de REA na prática pedagógica mostram que os recursos são utilizados no intuito de proporcionar novas experiências de aprendizagem para os alunos, independentemente do contexto ou sistema educacional. Também são apresentadas pesquisas sobre a atuação do professor com os recursos educacionais no que tange ao uso, adaptação e autoria.

Quanto aos tipos de usos que professores da educação básica fazem dos RED, um estudo bibliométrico de teses e dissertações brasileiras constatou que os recursos são levados para a sala de aula com a função pedagógica de fixar conteúdos ou realizar atividades práticas sobre um conteúdo, sendo em sua maioria relacionados a componentes da área de exatas (UEHARA et al, 2017). Na pesquisa de Castro (2014) verificou-se que os principais recursos buscados por docentes eram os multimídias, textos, apresentações e vídeos. A autora atribui especial atenção para os recursos de apresentação como o Powerpoint por acreditar que estes são utilizados de modo a transmitir conteúdo aos alunos de forma tradicional, mas inserindo a tecnologia nessa prática. A mesma perspectiva foi encontrada nos resultados de Uehara et al. (2017). Quanto à apropriação que estes professores fazem dos recursos, o estudo de Castro apontou que os professores, em sua maioria, apenas os consomem, efetuando quase nenhum compartilhamento com os alunos e uma pequena demonstração de compartilhamento com os pares. Embora atribuíssem grande importância para tais práticas no cotidiano escolar.

Também nas pesquisas de Guacaneme-Manecha et al., (2016) e Martinez et al. (2016) verificou-se que os professores utilizam os recursos como suporte aos conteúdos que precisam ser ensinados, tais como introduzir temas, expor conceitos, dar informação geral, realizar avaliações. Além disso, de acordo com Martinez et al. (2016), o trabalho pedagógico com os recursos educacionais contribuiu para que os docentes planejassem, desenhassem, implementassem e monitorassem atividades educativas. 
Já Littlejohn et al. (2008) buscaram identificar quais as características dos recursos educacionais que provocam mudanças no processo de ensino e aprendizagem. Foram mapeadas no estudo doze características principais: fácil localização; durabilidade; garantia de qualidade; livre de restrições legais; relação custo-benefício, acessibilidade; linguagem; reutilização; contextualização; granulosidade; envolvimento do aluno; e reusabilidade em diferentes modelos educacionais.

Os autores demonstraram como as características mapeadas estavam justapostas nos quatro estágios de usos dos recursos, ressaltando, porém, que um recurso não precisa estar estático em uma única categoria, visto que ao ser adaptado a um determinado contexto, suas características podem ser mudadas, acarretando em uma movimentação entre os tipos de uso. Segundo os autores, o estudo contribuiu para que eles pudessem voltar suas atenções para os modos em que os recursos são gerados, circulados e usados, indo além de pensar apenas nos tipos de usos de recursos e onde eles se enquadram.

Outros estudos (CLEMENTS; PAWLOWSKI, 2012; HILTON III; WILEY; LUTZ, 2012; BEAVEN, 2013; VAN ACKER et al., 2014) têm se debruçado sobre a apropriação que os professores fazem dos recursos educacionais digitais, especialmente os que foram desenvolvidos sob a perspectiva da filosofia de abertura, os REA.

As pesquisas de Clements e Pawlowski (2012) e Beaven (2013) se dedicaram a compreender as práticas de uso e reuso de REA pelos professores. No primeiro estudo ficou evidente que os professores usuários de repositórios fazem reusos dos recursos, tais como buscar, avaliar a qualidade, adaptar e usar, mas não compartilham o recurso modificado com os pares. Entre as barreiras para o compartilhamento foram identificados problemas de compatibilidade curricular, com direitos autorais e variação de conteúdo entre os países.

Resultados semelhantes foram encontrados no segundo estudo, em que demonstrou que o professor realiza pequenas adaptações antes de utilizar um recurso. De acordo com Beaven (2013), ainda que não haja nenhuma modificação física, o objetivo pedagógico de um recurso pode ser transformado ao ser trabalhado 
em um contexto diferente do que fora pensado inicialmente. Assim como no primeiro estudo, os docentes não retornam ao repositório com os recursos modificados. Acrescentam-se aos motivos já expostos, a percepção de que tais mudanças são muito pessoais para caber nas propostas de outros professores. Por outro lado, os recursos são compartilhados e reusados por docentes dentro do mesmo contexto educacional.

Resultados semelhantes foram encontrados no trabalho de Van Acker et al. (2014), em que se verificou que os professores eram mais propensos a compartilharem materiais de baixa complexidade como imagens e textos e que isso ocorria duas vezes mais de forma interpessoal com os pares em seu contexto profissional do que em websites como os repositórios.

Lembramos que um dos principais atrativos dos REA é a possibilidade de modificar, compartilhar e reusar em diferentes contextos pedagógicos. Hilton III et al. (2012) desenvolveram uma pesquisa para compreender se os livros didáticos abertos de uma determinada coleção estavam sendo revisados, remixados e reusados em diferentes contextos educacionais. De acordo com os autores, apenas 7,5\% das adoções dos textos apresentaram algum tipo de modificação, sendo entre essas: adições (16.6\%) ou remoções $(60.3 \%)$ de textos ou capítulos, imagens; reordenação (40.5\%) de capítulos ou ordem dos textos e remix (1.7\%), customização do livro com o uso de outros recursos. Os resultados desta pesquisa demonstram um enorme gap entre as potencialidades da filosofia dos recursos abertos e o comportamento dos professores com relação às práticas que sinalizassem algum nível de autoria.

Por outro lado, pesquisas dentro de projetos que incentivam práticas de autoria de RED e REA têm evidenciado que os professores vêm conseguindo construir processos de autoria com os recursos. O trabalho de Hadjerrouit (2010) apresenta uma abordagem para a criação de RED que ao invés de ser focada nas habilidades técnicas do recurso seria focada nas habilidades pedagógicas, isto é, que fossem incorporados ao desenvolvimento de um RED as condições da sala de aula e do contexto educacional. Outra linha foca em projetos para professores em formação inicial desenvolvendo competências tecnológicas e pedagógicas para a criação e/ou adaptação de recursos educacionais (HUGHES e MCKENNA, 2012; 
BAGETTI, MUSSOI e MALLMANN, 2017). Em tais iniciativas os resultados se mostraram positivos quanto às possibilidades de autorias com REA. Também os trabalhos de Leffa (2016) e Sapire e Reed (2011) demostraram que pesquisas dentro de projetos de formação continuada com professores em serviço resultaram em práticas autorais desses professores, seja na adaptação e remix ou na criação de novos recursos digitais.

\section{Fatores motivacionais que influenciam o uso de RED e REA pelos professores}

Uma segunda categoria de pesquisa se voltou a compreender quais são os fatores que contribuem para que os professores utilizem os RED, assim como o que os motivam a compartilhar, adaptar e criar recursos. Como explicitamos acima, ainda são poucas as iniciativas em que são alcançadas todas as potencialidades dos recursos educacionais que se alinham a filosofia da abertura, especialmente no que diz respeito aos aspectos autorais e de compartilhamento. No entanto, ainda que poucas, algumas pesquisas vêm identificando elementos e condições para que os educadores consigam fazer pleno uso dos RED.

Alguns dos fatores que podem aumentar o uso e a criação dos recursos educacionais foram reconhecidos por McKerlich et al. (2013), que os identicaram como: busca pela qualidade acadêmica; tempo gasto para encontrar, revisar e selecionar um recurso; conhecimento que o professor tem sobre recursos educacionais; desejo de reduzir custos para estudantes; facilidade de uso de software e hardware e comprometimento com o seu meio. Com respeito à criação de recursos educacionais, os autores discerniram: a busca pela qualidade acadêmica, o suporte ou apoio da equipe de trabalho, o conhecimento em relação aos recursos, hardware e software e o apoio administrativo.

Os fatores encontrados pelos autores nos ajudam a inferir que tanto o uso como a criação de RED conversam com o tipo de comprometimento que o docente tem com o seu fazer pedagógico, nos levando a crer que o comprometimento pode apresentar um aspecto relevante para tais práticas. Os estudos de Algers e Silva- 
Fletcher (2015) assim como Pirkkalainen, Jokinen e Pawlowski (2014) se dedicaram a compreender as relações entre a motivação e o uso, criação colaborativa e compartilhamento de recursos.

Segundo Algers e Silva-Fletcher (2015) as dimensões das motivações para a adoção de recursos educacionais são complexas e podem estar relacionadas ao campo de ensino do professor. Em relação aos fatores motivacionais que estão ligados aos benefícios de se utilizar REA, foram constatados: outreach reason - ou um comprometimento com a dimensão democrática de se compartilhar o conhecimento, que segundo os autores podem estar relacionado com o altruísmo que fora compreendido como o mais importante fator que pressupõe a intenção de compartilhar; collective reason - que está ligada à satisfação de se compartilhar com os pares as afinidades, preocupações e atividades colaborativas. Para os autores, a dimensão coletiva é explicada pela satisfação em moldar a ação significativa entre os participantes com envolvimento mútuo. Também se verificou que se um recurso compartilhado é usado e apreciado pela comunidade o autor estará mais propenso a compartilhar outros REA no futuro, retroalimentando uma rede colaborativa altamente motivada; expansive reason - o comprometimento com o ensino expansivo ou a crença de que o REA pode contribuir para a expansão da aprendizagem ao longo da vida ou para alcançar novos grupos. Como fatores que se relacionaram às três categorias, os autores encontraram a satisfação pessoal associada à colaboração com os pares e ao compartilhamento do conhecimento e às expectativas internas (práticas modernas de ensino, inovação) e externas (desenvolvimento da própria didática e atração de alunos) sobre o REA.

Já o trabalho de Pirkkalainen, Jokinen e Pawlowski (2014) se concentrou em investigar as barreiras ou a falta de motivação para o uso e o compartilhamento de REA, sendo: (a) a falta de suporte organizacional para o uso de REA, contemplando falta de formação, carência de práticas comuns para o uso de REA; (b) fatores associados a barreiras linguísticas e culturais, tais como distância cultural entre o recurso e o impacto dessa distância em um novo contexto e a falta de informações contextuais sobre a origem de um recurso; e (c) dificuldade de avaliar a qualidade do recurso e sua relevância. De acordo com os autores, a barreira linguística e cultural são as maiores barreiras ou fatores desmotivacionais para o 
uso dos recursos. Nesse sentido, quanto menos dificuldade o professor experimentar com a língua e a cultura de um recurso, maior propensão à adaptação e compartilhamento do mesmo. Resultados similares foram encontrados por Algers e Silva-Fletcher (2015), acrescentando-se a preocupação com a adaptabilidade pedagógica do recurso em um novo contexto, o REA como ameaça à robustez acadêmica e questões de direitos autorais.

Outro fator que pode ser incluído nas barreiras para o compartilhamento de recursos é o apego emocional, estudado por Pirkkalainen, Pawlowski e Pappa (2017). O estudo levanta uma discussão sobre a propriedade emocional das ideias e como isso pode se relacionar com o comportamento do educador em compartilhar e desenvolver recursos colaborativamente com seus pares. Segundo os autores, quanto mais apego o professor tiver com uma ideia, mais hesitante ele será em compartilhar esse conhecimento com outros. Entre os elementos que poderiam fortalecer o engajamento do professor com a colaboração e o compartilhamento foram evidenciadas as experiências prévias de co-criação com os pares, o comprometimento afetivo com a comunidade de prática, a confiança e a segurança.

\section{O impacto do uso de RED e REA na prática educacional}

O terceiro nicho de pesquisas diz respeito aos ganhos que os recursos educacionais têm levado para o processo de aprendizagem. Percebemos que a utilização de RED no ensino está relacionada com o desenvolvimento de novas estratégias de ensino, maior alcance dos objetivos de aprendizagem, aumento do uso da tecnologia em sala de aula e mudanças na relação aluno-material didático.

Os trabalhos de Castro-Filho et al. (2008) e Teruya et al. (2013) mostraram que o professor, ao utilizar os RED, contribui para que o aluno desenvolva novas estratégias para a resolução de problemas. De acordo com Teruya et al. (2013), a presença destes recursos permitiria aos alunos interagirem entre si à medida que se engajam nas atividades propostas, criando uma comunidade de aprendizagem.

Blomgren (2018), em um estudo sobre o uso de REA no ensino superior e na educação básica, verificou que, em ambos os contextos, a utilização de REA 
pelos professores corrobora para a diferenciação e personalização do ensino, o desenvolvimento da criatividade do professor, a contextualização do currículo, o estímulo para que alunos criem conteúdos e para que professores exercitem os $5 \mathrm{Rs}$ da filosofia da abertura (reuso, revisar, remixar, redistribuir e reter $^{6}$ ). Resultados similares foram encontrados nos estudos de Kwak (2017) e Murphy e Woldenfen (2013). A primeira pesquisa revelou que para 92\% dos estudantes a utilização de RED é benéfica em seu processo de aprendizagem e acreditam que a prática pedagógica com recursos estimula os professores a criarem novos planejamentos e estratégias com os mesmos. Já nos estudos de Murphy e Woldenfen (2013) foi demostrado que os REA contribuíram para a mudança no modo de participação dos alunos, que passou a ser mais motivada e autônoma, e para a melhoria da qualidade da aprendizagem dos discentes. Para as autoras, o uso dos REA possibilitou maior integração entre a teoria e prática do conhecimento aprendido e o aluno passou ser encarado como o centro do processo de aprendizagem. Além disso, observaram que os conteúdos ficavam mais atraentes à investigação por parte dos alunos, colaborando para que o valor do conhecimento aprendido fosse além do ambiente escolar.

No estudo de Weller et al. (2015) ficou evidente que o uso de REA pelos professores demonstrou um alcance positivo na percepção dos alunos sobre a aprendizagem, estimulou a reflexão dos professores sobre a prática de adoção de REA e contribuiu para a melhoria da performance discente. Entre os benefícios destacam-se a economia de custos pelos estudantes, acesso ao material pedagógico logo no início do curso, se refletindo na qualidade da aprendizagem e a confirmação dos docentes de que o acesso ao recurso aberto foi benéfico para o rendimento do aluno.

Resultados similares foram encontrados na pesquisa de Bliss et al. (2013), em que através de uma abordagem quantitativa de larga escala procuraram compreender o entendimento de professores e estudantes sobre o alcance do uso de REA na aprendizagem. De acordo com os autores, as principais influências apresentadas foram a redução do custo dos materiais didáticos: aumento do tempo gasto com o planejamento das aulas; aumento do uso da tecnologia em sala de aula;

\footnotetext{
${ }^{6}$ Reuse, revise, remix, redistribute e retain
} 
aumento do engajamento e interesse dos alunos no material didático utilizado; aumento de atividades voltadas ao planejamento pedagógico, avaliações e maior cobertura do conteúdo; criação de mais formas de avaliação e de ferramentas; e estratégias de aprendizagem.

Já a investigação de Mason e Kimmons (2018) realizou um estudo comparativo entre as práticas dos professores antes e depois de adotarem livros didáticos abertos. Semelhantemente ao estudo de Hilton III et al. (2012), a pesquisa mostrou que os professores estavam mais propensos a atribuir leituras, perguntas ou atividades de seus livros abertos do que revisar, adaptar ou colaborar com colegas ou alunos para selecionar e adaptar materiais durante o uso do livro aberto. Quanto aos alcances que o uso do livro aberto provocou, foram percebidos o maior uso de materiais digitais em detrimento de impressos; cobertura mais eficiente dos conteúdos a serem trabalhados; maior uso da tecnologia ou aspectos multimidiáticos inseridos no livro digital aberto; flexibilização e maior possibilidade de estudo independente; aumento da habilidade dos professores em utilizar outros recursos digitais em conjunto com o livro digital aberto; diminuição ou ausência de custo com material didático; maior qualidade do livro aberto, no sentido de se adequar melhor às necessidades dos professores; e incentivo à adaptação e revisão colaborativa entre pares do livro aberto. Com respeito ao último elemento, a pesquisa mostrou que os participantes se sentiram estimulados a revisar e adaptar o material devido à flexibilidade do livro aberto, desencadeando em um trabalho colaborativo com os pares para selecionar, revisar e adaptar materiais instrucionais, provocando maior satisfação dos professores.

Os três eixos de pesquisas previamente discutidos contribuem para o entendimento de onde esta pesquisa se situa. Para além de compreender os tipos de usos que professores fazem com os RED, o estudo se debruça em buscar relacionar o uso dos recursos e o processo de ensino e aprendizagem, assim como o processo de autoria do professor e envolvimento com o uso dos recursos e suas competências digitais. 


\section{3}

\section{Perspectivas sobre os processos autorais dos docentes}

No campo da educação é cada vez mais notável o interesse no tema da autoria. Defende-se que a escola é um espaço de criação autoral e que professores precisam formar alunos autores, necessitando, antes de tudo, que estes se compreendam como um docente autor. Também é recorrente a ideia que os artefatos tecnológicos, assim como estar imerso na cultura digital promovem sujeitos autores.

Algumas pesquisas vêm se debruçando a investigar como as tecnologias digitais potencializam a autoria dos professores (NAUMANN, 2016; VELOSO E BONILLA, 2018; SOUZA et al. 2011; MARTINS, 2012) e vários foram os achados que demonstraram que ser digitalmente letrado influencia positivamente em suas criações. Contudo, essas mesmas pesquisas nos levam a indagações que não têm sido respondidas em suas linhas, remetendo-nos a um passo atrás, no sentido de buscar descortinar o conceito de autoria e sua relação com a docência. Assim, dedicamo-nos neste tópico a discutir o que é autoria e como se define um professor autor.

\subsection{1}

Autoria

Para introduzir o tema da autoria recorremos ao significado etimológico da palavra. Segundo Machado (1967, p 355), o conceito de autor pode ser definido como:

O que aumenta, que faz avançar, produzir; o que aumenta a confiança; fiador; que confirma autoridade, fonte; modelo, senhor, autoridade; fonte histórica; o que obriga a agir; conselheiro, instigador, promotor; criador, iniciador, fundador, autor; o que faz (compõe) uma obra, escritor [...] (grifo nosso) 
Através do enxerto percebemos que o conceito de autor possui relação com o coletivo. Ideias como fazer avançar, autoridade, o que obriga a agir e instigador só fazem sentido se pensarmos que o autor só avança se tiver ponto, ideias e leituras de partida, só se torna modelo ou autoridade se tiver o outro que o perceba assim, e por fim, só obriga a agir ou se torna instigador se existir o leitor, ou aquele que dá sentido à sua obra, ou que age a partir dela. Considerar essa definição de autor nos ajuda a compreender como o conceito de autoria tem sido ressignificado a depender do contexto histórico e social de quem o defende.

Traçando um perfil histórico, a ideia de autoria começa no século XVIII. De acordo com Woodmansee (1984), a noção de "autor" surgiu em decorrência do crescimento de um grupo de escritores que visavam vender suas obras para um novo e crescente público de leitores, mas se viram diante da falta de uma garantia de proteção de seus escritos. A autora explica que em resposta a esse problema e também como uma forma de responder às demandas econômicas à época, grupos de escritores redefiniram a natureza de uma produção escrita, reivindicando o direito de viver de seu trabalho intelectual, refletindo na concepção moderna de autoria. Concordando com Woodmansee, Silva (2015) explica que o conceito de autoria foi criado a partir de ordens judiciais que se relacionavam com a propriedade. Para o autor, "assim como todas as outras formas de representação, a autoria passou a ser operada como uma ferramenta inquestionável na formação da propriedade privada" (p. 97, tradução nossa ${ }^{7}$ ). A consolidação do indivíduo como proprietário de sua obra se deu em 1709 através da primeira legislação referente ao direito autoral, conhecida como "Statute of Anne".

Outra contribuição para o conceito moderno de autoria foi a concepção do autor como gênio criador, ideia amplamente promulgada durante o Romantismo. Martins (2012) explica que tanto na antiga Grécia como na Idade Média o ato de criação estava sempre relacionado com o divino, possuindo um caráter transcendental. Nesse sentido, o poeta ou escritor não produzia a partir de si, mas através de uma inspiração exterior.

\footnotetext{
${ }^{7}$ All forms of human representation, authorship came to be operated as an unquestionable tool in the formation of private property.
} 
Esse entendimento sobre a criação muda quando a subjetividade passa a ser o principal elemento do processo de autoria. $\mathrm{O}$ autor passa a ser concebido como um gênio criador, dono de sua própria inspiração. E como esse indivíduo é cada vez mais creditado por sua genialidade, é transformado em um sujeito único, responsável por um produto uno. Woodmansee (1984) é assertiva ao dizer que o escritor passa de um mero veículo de agências superiores para se tornar autor daquilo que produz.

Com respeito à relação autor-leitor no campo literário, Bennet (2004) compreende a figura do autor como uma presença enigmática e não especificada. O teórico defende que textos literários podem gerar sentimentos de identificação, não somente entre o leitor e a personagem, mas também entre o leitor e o autor. Nesse sentido, o leitor pode sentir o autor como um grande amigo seu, ou imaginar que consegue compreender como ninguém o que o autor realmente quis dizer, ou achar que suas ideias podem expressar as opiniões, pensamentos e sentimentos do leitor, melhor do que ele mesmo poderia expressar. Identificamos na fala de Bennet a autoridade do autor, ou seja, na relação autor-leitor o autor é detentor de todos os significados e/ou interpretações de sua obra.

Arriscamo-nos a dizer que até o século XIX compunha o conceito de autoria a noção de propriedade privada, de gênio criador e do autor como fonte de autoridade. A ideia imaculada sobre o autor só começa a ser questionada com mais intensidade a partir do século XX, especialmente por Barthes e Foucault.

As contribuições desses autores para se pensar autoria docente foram compreendidas e interpretadas como i) a compreensão do texto como espaço de múltiplas dimensões oriundo de mil focos de cultura; ii) as possibilidades infinitas de um texto; iii) o leitor como significado último de um texto; e iv) o autor como um instaurador de discursividades.

A autoridade do autor ou a visão do autor como início, meio e fim das significações de um texto é posta em xeque por Roland Barthes e ganha grande projeção a partir de sua célebre afirmação o Autor está morto. O teórico define o autor como uma personagem moderna, produzida sem dúvida por nossa sociedade que descobriu o prestígio do indivíduo, iniciando assim, o Império do Autor. No 
entanto, esse império começa a ser abalado quando a linguagem passa a ser compreendida como o principal elemento de um texto. É a linguagem quem fala, não o autor.

Para Barthes (2004) foi a partir dos trabalhos de Mallarmé, Valéry e Proust que a linguagem passou a ser concebida como o ator principal em um processo de escrita. Fora da literatura, Barthes aponta que a linguística forneceu um instrumento analítico precioso para a destruição do autor, isto é, mostrando que "a enunciação é um processo vazio que funciona sem que seja necessário preenchê-lo com interlocutores" (BARTHES, 2004 p.62). Para Barthes, linguisticamente o autor nunca é mais do que aquilo que escreve, assim como o "eu" outra coisa não é senão aquele que diz "eu".

Barthes coloca também em xeque o discurso da originalidade e da genialidade do Autor. Ele defende que o texto é um espaço de múltiplas dimensões, uma trama de diferentes escrituras, em que nenhuma é original, ou seja, "um tecido de citações oriundos de mil focos de culturas" (p. 62). Nessa concepção, "o escritor pode apenas imitar um gesto sempre anterior, jamais original; seu único poder está em mesclar as escrituras, em fazê-las contrariar-se umas pelas outras, de modo que nunca se apoie em apenas uma delas" (p. 62).

Outro efeito que a morte do autor tem sobre um texto é que, uma vez que o Autor não mais existe, o anseio de decifrar um texto se torna desnecessário. No discurso de Barthes, quando o texto tem um autor é imposto nele uma trave, ou a necessidade de um significado último. Quando a escrita não tem um Autor, seguindo a ideia do texto com um espaço de múltiplas dimensões, a estrutura de um texto pode ser desfiada "em todas as suas retomadas e em todos os seus estágios, mas não há fundo; o espaço da escritura deve ser percorrido e não penetrado; a escritura propõe sentido sem parar" (p. 63). Outrossim, poderíamos dizer que com a morte do Autor as possibilidades de um texto se tornam infinitas. Como não há um ser único em que se possa atribuir identidade, o texto se torna vivo, disseminando-se ao entrar em contato com outros textos e outras vozes.

Por fim, o último aspecto levantado com relação à morte do Autor é a emergência do leitor. Segundo Barthes, o leitor é o ser total da escritura, pois é nele 
que se reúne toda a multiplicidade de um texto. É no leitor que se inscrevem todas as citações, o destino último de um texto. Nesse sentido, Barthes é assertivo quando diz que "para devolver à escritura o seu futuro, é preciso inverter o mito: o nascimento do leitor deve pagar-se com a morte do Autor" (p. 64). O leitor se torna responsável por dar o significado último a um texto, como se fosse atualizado nele, tornando-o assim também escritor ou co-autor.

Bennet (2004) explica que a intenção de Barthes fora argumentar contra uma das mais comuns atribuições do Autor - sua autoridade enquanto possuidor do início e fim dos significados de um texto. No entanto, segundo esse mesmo estudioso, Barthes não oferece uma solução para esse conflito, pois transfere para o leitor a autoridade de significar um texto.

Outro teórico que traz contribuições significativas para a compreensão dos conceitos de Autor e Autoria é Michel Foucault. O filósofo concorda com Barthes em relação ao desaparecimento do Autor, contudo, acredita que compreender a morte dele não é suficiente. De acordo com Bennet (2004), o trabalho de Foucault consegue ser mais rigoroso e sistemático que o de Barthes, especialmente por trazer a ideia da figura do autor como uma construção histórica, pois acredita que a figura e o significado do autor variam através do tempo, de uma cultura para outra e de um discurso para outro.

Foucault defende a necessidade de "localizar o espaço assim deixado vago pelo desaparecimento do autor, seguir atentamente a repartição das lacunas e das falhas e espreitar os locais, as funções livres que essa desaparição faz aparecer" (FOUCAULT, 2001, p. 11). Buscando compreender os espaços deixados pela morte do Autor, emerge o conceito da função-autor.

Para entender esse caráter histórico de autor e autoria, Foucault explica que o nome do autor pode ter função indicativa, remetendo ao indivíduo autor; função descritiva, sendo esse mesmo nome usado para descrever gêneros ou conceitos; e uma função de designação, a ligação ou obrigação com aquilo que ele nomeia. Nesse sentido, Foucault conclui que o nome do autor não é um nome próprio como os outros, pois exerce um certo papel em relação ao discurso. Por fim, no intuito de diferenciar o nome do autor de um nome próprio qualquer, Foucault argumenta que 
O nome do autor funciona para caracterizar um certo modo de ser do discurso: para um discurso, o fato de haver um nome de autor, o fato de que se possa dizer "isso foi escrito por tal pessoa", ou "tal pessoal é o autor disso" indica que esse discurso não é uma palavra cotidiana, indiferente, uma palavra que se afasta, que flutua e passa, uma palavra imediatamente consumível, mas que se trata de uma palavra que deve ser recebida de uma certa maneira e que deve, em uma dada cultura, receber um certo status. (FOUCAULT, 2001, p. 13)

Como podemos observar, o nome do autor está intimamente relacionado com a função social que ele ocupa e com o seu papel em relação ao discurso, sendo isto parte da função-autor. Foucault explica que a função-autor
está ligada ao sistema jurídico e institucional que contém, determina, articula o universo do discurso; ela nasce se exerce uniformemente e da mesma maneira sobre todos os discursos, em todas as épocas e em todas as formas de civilização; ela não é definida pela atribuição espontânea de um discurso ao seu produtor, mas por uma série de operações específicas e complexas; ela não remete pura e simplesmente a um indivíduo real, ela pode dar lugar simultaneamente a vários egos a várias posições-sujeito que classes diferentes podem vir a ocupar. (FOUCAULT, 2001, p. 20).

Implícita na função-autor está também a relação de apropriação. Ela é similar ao que já fora apresentado por Woodmansee e diz respeito ao sentimento de propriedade que o autor tem pelo seu trabalho. O discurso enquanto objeto de apropriação passou a ser visto como um produto, mostrando assim que seu sentido de propriedade está relacionado em como esse discurso circula em um determinado momento histórico. Outro aspecto implícito é a relação de atribuição como uma projeção daquilo que faz o indivíduo ser designado como autor, e isso inclui o tratamento que se dá aos textos, as aproximações, continuidades e exclusões que se pratica em um texto. Para o teórico, não se constrói um 'autor filosófico' como se constrói um 'poeta', a cada um são dadas atribuições diferentes. 
Outro aspecto importante é a compreensão do autor como o início de um agrupamento do discurso, isto é, a clara noção de que o autor não é um gênio iluminado detentor de um trabalho original, mas um instaurador de discursividades. Assim, a partir do trabalho de sua autoria é viável estabelecer possibilidades infinitas de discursos, ou seja, a função de autor vai além da própria obra. O instaurador de discursividade abre espaço para outras autorias que pertencem ao que ele fundou anteriormente, o que Foucault (2001) chama de “costura enigmática da obra e do autor" (p. 285).

\subsection{2.}

\section{Síntese das pesquisas sobre autoria}

No intuito de compreender como esse conceito vem sendo abordado no campo da educação, realizamos uma pesquisa com as palavras-chave "autoria" e "professor" ou "autoria" e "docente" no catálogo de teses e dissertações da Capes. Foi feita a filtragem pela área de conhecimento "educação" nos últimos dez anos (2008 - 2018), optou-se pelo recorte nas teses de doutorado. Foram encontradas 12 teses que abordaram o tema da autoria, categorizadas em pesquisas sobre a autoria discente; pesquisas sobre a autoria docente; e pesquisas que firmaram um diálogo entre a autoria docente e a cultura digital.

De uma forma geral, percebemos que as pesquisas indicam que a autoria discente pode ser desenvolvida ou aprendida durante o processo de escolarização, apresentando-se em duas categorias: i) atividades escolares escritas, como foi o caso da pesquisa escolar, ou projetos que culminam na produção escrita considerando o contexto dos alunos. Nesta perspectiva estão os trabalhos de Dias (2017), Fuchs (2016) e Fortunato (2009); e ii) atividade escrita que não produz sentido para o aluno, sendo desconectada da experiência discente e tendo apenas o valor instrumental da atividade escolar, como abordou a pesquisa de Aguiar (2010).

A pesquisa de Dias (2017) procurou compreender se nas escolas havia espaço para a construção autoral dos estudantes em seus trabalhos de pesquisa. $\mathrm{O}$ autor, através de entrevistas com professores, alunos e profissionais setorizados, encontrou que existem trabalhos criativos que atendem aos interesses do aluno e 
que a autoria tem sido exercida na pesquisa escolar. De acordo com o autor, existe sim expressão autoral e criativa nas atividades de pesquisa, contudo falta espaço para o ensino pormenorizado e criterioso dessa prática nas escolas estudadas.

Fuchs (2016) procurou pensar a autoria em produções textuais de alunos do ensino médio. A autora partiu do pressuposto de que a noção de autoria vai além do sujeito que assina o texto. Através de um projeto que envolveu toda comunidade em que a escola estava inserida, a autora analisou o processo de autoria na produção textual coletiva dos alunos e as interferências produzidas pela relação escola e comunidade nesse texto, analisando os indícios de autoria na materialidade textual. Dentre os resultados apontados por Fuchs (2016), verificou-se que a escrita do texto coletivo não acontecia por meio da soma de frases, mas que havia uma negociação que antecedia o trabalho da construção textual, ou seja, um processo colaborativo.

Uma pesquisa similar foi realizada por Aguiar (2010), que buscou viabilizar uma discussão sobre as noções de escrita, autor e autoria para se pensar sobre a possibilidade de trabalho com a escrita autoral e a constituição do sujeito-autor no contexto escolar. O estudo examinou o processo de escrita de quatro estudantes e apresentou como resultado que na escola a escrita é valorizada por sua função instrumental ou como um pretexto para o aprendizado de conteúdos e como respostas às demandas escolares. Verificou-se também que a escrita era promovida como uma ação desconectada da experiência subjetiva do ato de escrever, impedindo assim a autoria e a constituição do sujeito-autor.

A pesquisa de Fortunato (2009) parte do princípio que ensinar e escrever textos é ensinar procedimentos de autoria. Assim, procurou-se compreender o processo de composição de escritos e interpretá-lo através das concepções de autoria de Foucault e Bakhtin. O estudo possibilitou a análise dos procedimentos de autoria da produção escrita de estudantes do Ensino Fundamental, descrevendo quais os procedimentos eram utilizados pelos discentes e como eles os utilizavam para a aprendizagem da escrita. Como conclusão, Fortunato (2009) defende que a aprendizagem da escrita requer a prática de composição de textos contínua para o seu desenvolvimento. Para tanto, o docente deve usar um conjunto de procedimentos sugeridos na análise de dados da pesquisa, a saber: procedimento de planejamento, de produção de texto, de revisão e de gestão de processos. 
Os trabalhos levantados sobre a autoria discente indicam que esta é construída a partir de práticas de produção textual durante o processo de escolarização, assim, perguntamo-nos se seria este também o processo de construção da autoria docente. Seria a autoria dos professores constituída através das produções textuais ou multimidiáticas? Como se compreende um docente autor?

Através do levantamento realizado percebemos que as pesquisas sobre a autoria docente sugerem a apresentação de três diferentes linhas: i) a autoria docente ocorrendo através do desenvolvimento profissional do professor na formação inicial (SALES, 2009) e no seu percurso profissional ou formação continuada (MAIA, 2017); ii) a autoria docente relacionada à tecnologia e à cultura digital na formação inicial de professores (MEDEIROS, 2011; HALMANN, 2011; AMARAL, 2014; JACQUES, 2017); e iii) a autoria docente potencializada pela cultura digital no campo de atuação dos professores (VELOSO, 2014; MAIA, 2017).

Sales (2009) investigou a autoria docente tendo como ponto de partida o processo formativo do professor. A intenção da pesquisa foi discutir em que medida o currículo em rede possibilita a autoria do professor em formação ao vivenciar o seu processo formativo, considerando essa autoria como o protagonismo do docente e sua autonomia na aprendizagem.

Também a partir do viés do desenvolvimento profissional, Maia (2017) buscou elaborar um instrumento de análise composto pelos eixos saberes docentes e autoria docente, sendo empregado para investigar o desenvolvimento profissional de professores que cursavam o mestrado profissional em ensino. A pesquisadora compreende o conceito de autoria como aquilo que o sujeito consegue produzir a partir da mobilização dos seus conhecimentos, valores e suas energias. Assim, a autoria se dá a partir da interação do professor com situações de seu processo formativo.

Os autores defendem que a autoria docente ocorre através do desenvolvimento profissional do professor, seja na sua formação inicial (SALES, 2009) ou no seu percurso profissional (MAIA, 2017). Outros trabalhos relacionam 
a autoria docente com as potencialidades das tecnologias da informação e da cultura digital (MEDEIROS, 2011; VELOSO, 2014; HALMANN, 2011; AMARAL, 2014; RODRIGUES, 2017; JAQCUES, 2017).

Medeiros (2011) buscou compreender as relações entre os contextos de autoria e o processo de letramento digital que foram vivenciados pelos sujeitos alunos do curso de pedagogia na modalidade a distância. Após mapear o perfil tecnológico dos estudantes, a pesquisadora pode compreender por meio da escrita on-line como se dava a relação do sujeito com o ambiente virtual. Para a autora, essa relação acontecia por meio da apropriação dos gêneros discursivos e na constituição e consolidação de novos gêneros digitais e acadêmicos.

A pesquisa de Hallmann (2011) voltou-se para o entendimento dos processos autorais na construção de conteúdo digitais e suas implicações para a apropriação científico-tecnológica na formação inicial de professores. O estudo mostrou que a inserção da tecnologia no ambiente educacional não determina os processos que podem ser desencadeados, mas promove condições para construções autorais. Também apresentou que os processos autorais com as tecnologias digitais possibilitam práticas educativas além das reprodutivistas, contribuindo para a apropriação científico-tecnológico do professor em uma perspectiva crítica e que a autoria abre espaço para a construção de sentidos pelo sujeito. Os resultados também atestaram que a autoria de conteúdos digitais possibilitou aos cursistas a desmistificação da verdade absoluta e neutra posta nos livros didáticos, e por fim, identificou a leitura como propulsora de processos autorais e novas escritas.

Amaral (2014) construiu indicadores que potencializassem e promovessem o surgimento de autorias docente e discentes na rede a partir de 'atos de currículo' (MACEDO, 2012 apud AMARAL, 2014). Segundo a autora, os indicadores dimensão integrativa, dimensão formativa, dimensão tecnológica- atuaram como disparadores para o surgimento de autoria em diferentes formas através de uma pesquisa-formação em turmas de licenciandos. Para a autora, na cibercultura a noção de autoria se torna coletiva e pulverizada, ainda que todos os sujeitos sejam potencialmente autores à medida que assumem uma posição responsiva e responsável por aquilo que expressa (AMARAL, 2014). 
Também focando na formação inicial de professores, Jacques (2017) procurou compreender em que medida a performance docente na coautoria de recursos educacionais abertos (REA) no ensino superior potencializaria atos estéticos. De acordo com a autora, a performance docente promove a superação da consciência ingênua, fortalecendo a consciência crítica nas escolhas relacionadas aos REA. Também apresentou que a autoria na docência denota ato ético que reflete na responsabilidade no ensino-aprendizagem, produzindo o desenvolvimento psíquico-intelectual dos envolvidos.

Quanto às investigações que se debruçaram sobre os professores em seus campos de atuações, temos a pesquisa de Veloso (2014) que buscou compreender como ocorre o processo de criação/autoria do professor no contexto da cibercultura. Foram analisadas as práticas pedagógicas de três professoras que participaram do Programa Um Computador por Aluno (PROUCA) e como resultado apontou-se que a ação docente autônoma e intencionada é fundamental para a autoria do professor. A pesquisa também mostrou que o professor 'autor-criador' se constrói na sua experiência, nas práticas e saberes refletidos de forma crítica e que a autoria docente ocorre quando o professor está aberto para inovações. Verificou-se que a autoria é fruto de saberes decorrentes da experiência, do convívio com as pessoas, com o mundo e com a cultura, e por fim, que o professor autor não nasce pronto, isolado em suas escolhas. Sua construção depende da dinâmica organizacional e institucional do contexto em que o professor se insere e das práticas coletivas construídas no cotidiano escolar e com a interlocução com a cultura.

Maia (2017) procurou analisar a produção e veiculação de narrativas digitais de aprendizagem como possibilidade para a criação de um currículo narrativo na formação de professores e sua influência na construção da autoria docente e na apropriação da tecnologia para uso pedagógico, tendo como locus uma disciplina semipresencial de um Programa de Pós-Graduação no Ensino de Ciências. Para a autora, essas narrativas podem ser vistas como potencializadoras da apropriação da função-autor pelos sujeitos e pelo processo de produção e veiculação das narrativas. Além disso, o compartilhamento das narrativas possibilitou um ciclo de autoria coletiva (MAIA, 2017). 
O retrato das pesquisas de doutoramento sobre autoria no âmbito da educação nos trouxe alguns indícios que nos ajudam a compor o conceito de autoria docente que contribuirá na análise dos dados desta pesquisa.

\subsection{3.}

\section{Origens da Autoria Docente}

Assumimos que a análise das teses nos ajudou a refletir sobre a origem da autoria docente e sua conceituação. Compreendemos que o desenvolvimento da autoria docente depende do i) contexto criativo e coletividade e do ii) desenvolvimento profissional do professor.

\section{Contexto Criativo e Coletividade}

O professor, ao estar imerso em um contexto criativo, pode ter aberto a possibilidade de desenvolver e promover a autoria docente. Acreditamos que o contexto afeta a autoria docente, assim como afeta a qualidade das produções ou autorias coletivas que poderiam emergir do diálogo do professor com seus pares.

Para tratar da dimensão contextual da autoria docente nos baseamos na ideia barthesiana de que um autor nunca é original, pois é resultado de múltiplas dimensões e das diferentes experiências culturais do escritor. Nesse sentido, o docente-autor não cria algo inédito sem influência ou leituras prévias, mas tece um novo texto a partir de escrituras anteriores. Para nós, esse contexto do professor é social e histórico, envolve as motivações e causas que levam o docente a ter contato com certas experiências culturais e não outras (OLIVEIRA E ALENCAR, 2014).

Refletindo sobre esse contexto que possibilita a autoria, acreditamos que essa precisa ser impregnada pela criatividade. Nossa intenção ao invocarmos a criatividade como o tipo de contexto precursor da autoria docente não é resgatarmos o ideal romântico do autor como um ser iluminado, revestido da genialidade e originalidade, mas sim apontarmos como o contexto criativo pode influenciar na construção da autoria docente. 
De acordo com Ostrower (1987), a criatividade ou o ato de criar é formar, ou dar forma a algo novo. Para a autora, o homem é um ser formador, ou seja, capaz de estabelecer conexões entre os diferentes eventos que ocorrem dentro dele e em seu contexto, sendo pelo ato de formar que o homem compreende a vida. Ostrower (1987) acredita que a atividade criativa é inerente ao homem como potência de um viver humano e defende que essa natureza ou potência criativa se desenvolve no meio cultural e no centro do indivíduo como ser único.

A definição da autora nos leva a acreditar que a criatividade existe, pelo menos em potência, em todo e qualquer ser humano. No entanto, se acionarmos nossas experiências com a criatividade, facilmente podemos chegar à conclusão que algumas pessoas são mais criativas que outras ou, ainda, que existem pessoas que não são criativas. De acordo com Alencar (1995), o que assinala se um indivíduo é mais criativo que o outro é a qualidade do produto final do processo criativo, considerando os fatores internos e externos que estiveram em jogo durante esse decurso. A autora também acredita que a criatividade pode ser desenvolvida em diferentes níveis, tendo potencial para ser expandida e aprimorada. Wechsler (2005) ratifica que a criatividade pode ser compreendida como um constructo multidimensional que envolve variáveis cognitivas, características da personalidade, aspectos familiares, educacionais, sociais e culturais, em que, interagindo entre si, dão origens aos estilos de pensar e criar em diversas formas.

Nesse sentido, embora existente em todo ser humano, a criatividade pode se manifestar em diferentes formas e níveis a depender do contexto do indivíduo. Sob essa mesma perspectiva, acreditamos que os diferentes níveis e formas de um contexto criativo influenciam na formação do docente autor, assim como na construção de processos autorais criativos no ambiente escolar. Por sua vez, isso nos leva a indagar em que medida o contexto criativo pode ter impactos na construção da autoria docente.

Pesquisas que se debruçaram na temática da criatividade do professor indicam que ela é formada por fatores individuais e externos, se dividindo entre os estudos que se voltaram para i) os componentes da expressão criativa dos docentes e para ii) as competências, ações e atitudes do professor criativo. 
Mariani e Alencar (2005) realizaram uma pesquisa em que se propuseram a investigar os componentes de organização do trabalho pedagógico e os elementos de caráter individual que agem como inibidores e facilitadores da expressão da criatividade de professores. Quanto aos componentes considerados importantes para a expressão criativa, foram apontados a liberdade, os recursos materiais, a possibilidade de trabalho em equipe, a relação professor-aluno, o tempo disponível e a valorização do professor. Com respeito aos elementos de caráter pessoal, os professores ressaltaram a paixão pelo trabalho, gostar da disciplina que leciona, busca pela transformação pessoal e profissional através do estudo, espontaneidade, descontração, bom-humor e inovação, ao otimizar a apropriação do conteúdo pelo aluno.

No tocante ao contexto, para que um professor criativo se manifeste, Sternberg e Lubart (1996) considera que a criatividade provém de fatores interrelacionados, a saber: inteligência, estilos intelectuais, conhecimento, personalidade, motivação e contexto ambiental. Assim, a criatividade só pode ser concebida dentro de um ambiente que facilite o desenvolvimento do potencial criativo, sendo que a efetividade desse ambiente ainda dependerá do potencial criativo intrínseco à pessoa e à área em que a pessoa criativa se expressa (OLIVEIRA E ALENCAR, 2014).

Outros indícios sobre a criatividade docente foram percebidos por Morais e Pinho (2017) ao refletirem sobre o papel da criatividade na formação continuada de professores. De acordo com os autores, o professor criativo está constantemente buscando estratégias pedagógicas para o aprender e o ensinar. Isto é, o docente com princípios criativos preocupa-se com seu entorno e ainda procura desenvolver um trabalho compartilhado para a transformação da sociedade.

Também Veloso e Bonilla (2018), ao abordar o processo de criação do professor, explicam que este acontece nas relações dos acontecimentos de percurso em um processo em rede. A criatividade do professor se conecta ao seu espaço e ao seu tempo, "articulando questões relativas à memória, à percepção, à escolha de recursos criativos, assim como as diversas maneiras como se organizam as tramas do pensamento em criação" (VELOSO; BONILLA, 2018, p. 10). Quanto às formas em que a criatividade docente se manifesta, as autoras destacam os momentos de 
conversas com os alunos ou com um colega, uma leitura, um objeto encontrado por acaso, uma pesquisa na internet ou até mesmo um olhar diferente para a prática que foi desenvolvida. De fato, fica-nos claro que a criatividade docente pode aparecer em qualquer momento, configurando uma rede de possibilidades de práticas criativas em que tudo pode ser sustentado como potencialidade para a criação.

Oliveira e Lima (2017) consideram o processo criativo como ponto essencial da docência, apontando que mediar a aprendizagem dos alunos exige criação e recriação dos conteúdos, de si, das relações interpessoais e do próprio sentido da docência, ou seja, exige autoria. Ainda que o exercício docente possa gerar práticas de reprodução e alienação, embarreirando a criatividade docente, os autores sustentam que ações preventivas e de articulação com outros elementos possibilitam a reconfiguração de um padrão já estagnado, tal como promover uma formação que crie espaços de participação, reflexão e desenvolvimento da criatividade docente.

Dentre as características de um professor criativo, as autoras o concebem como estando aberto a novas experiências, curioso, tendo confiança em si próprio, encarando o erro como processo de aprendizagem e provendo oportunidades para desenvolver o potencial criativo de seus alunos. Oliveira e Alencar (2014), ao investigarem sobre como discentes da pós-graduação compreendem o professor criativo, apontaram quatro categorias em que a criatividade docente se manifesta: i) estratégias de ensino, tais como inovação, busca de novas maneiras de ensinar, aulas mais dinâmicas, interligação de sua disciplina com outras, estímulo a participação e ao pensamento crítico e reflexivo do aluno; ii) atributos pessoais como ousadia, entusiasmo pela profissão e flexibilidade; e iii) características de relacionamento, se traduzindo no diálogo com os alunos, dar autonomia, feedbacks e respeitar as ideias dos alunos.

Já no tocante aos processos pedagógicos de um professor criativo, os alunos assinalaram os i) procedimentos em aulas - despertando maior interesse discente por meio de métodos inovadores, aliança da prática com a teoria, diálogo interpessoal e adoção de novas práticas de ensino; ii) procedimentos interdisciplinares - por abranger o diálogo com outras disciplinas e áreas do 
conhecimento; iii) procedimentos avaliativos - por pensar em diferentes abordagens de avaliação.

Arriscamo-nos a dizer que a criatividade é uma característica imprescindível para a construção de um docente autor. Os achados das pesquisas discutidos nos ajudam a inferir que, assim como em relação à criatividade, todo professor é potencialmente autor desde que elementos internos e externos aos docentes sejam acionados. Também demonstra que a criatividade docente não se limita a invenções de novas metodologias ou conteúdos por parte do professor, mas envolve uma rede de relações composta pela filosofia educacional, contexto em que este se insere, infraestrutura disponível, conhecimentos e características pessoais.

Para a constituição de um contexto criativo temos claro a importância do papel da coletividade, especialmente quando tratamos do profissional docente, pois mesmo o processo criativo sendo aparentemente solitário ele é coletivo se levarmos em consideração o contexto e os pares com quais esse autor dialoga. A coletividade presente na profissão docente se manifesta pelas interações com os seus pares.

Pensar o contexto criativo e a coletividade como elementos originários da autoria docente envolve considerar o trabalho coletivo como espaço de negociação. Fuchs (2016, p. 80) explica que a negociação em um processo de criação "está no nível da constituição do sentido, não sendo possível identificarmos quem é o autor de uma ou de outra parte do texto, mas encarando que todos são sujeitos responsáveis por sua formulação na totalidade”. Essa produção coletiva é compreendida como um trabalho de incertezas, de conflito e de tensões que se desloca para um processo de reconstrução das vozes e dos sentidos.

Em se tratando de professores, acreditamos que os fatores contexto e coletividade são ainda mais evidentes. De acordo com Passos et al. (2006), a coletividade é um dos elementos da formação e desenvolvimento profissional do professor, visto que o trabalho colaborativo se converte em um contexto favorável à aprendizagem contínua do docente. Segundo as autoras, a coletividade no trabalho docente ocorre por meio da construção de um diálogo aberto; da confiança, respeito e apoio mútuos; e de ações planejadas e negociadas coletivamente. Assim, o trabalho coletivo torna-se um espaço privilegiado para o processo de reflexão dos 
professores, para a criação e consolidação de seus saberes profissionais e para a sua autonomia e emancipação.

De acordo com Nornberg e Silva (2014), as práticas colaborativas de formação docente se associam com a busca pelo aperfeiçoamento do professor com a análise crítica do seu fazer pedagógico e isso, consequentemente, se alia ao seu contexto de docência. Para as autoras, compreender o trabalho colaborativo dos docentes implica olhar para o conhecimento que eles produzem em seu cotidiano, tendo como base seus valores, certezas, incertezas e possibilidade de ações.

Um caminho indicado, de forma a aproveitar o cotidiano do professor para o desenvolvimento da autoria docente, é escrever sua própria experiência. De acordo com as autoras, isso permite a criação de um processo que, além de reconstruir sua relação com a escrita, dando um novo sentido à trajetória do professor, concede ao docente condições para oferecer aos seus alunos outro tipo de experiência e relação com a escrita autoral. Dentre os ganhos apresentados, Nornberg e Silva (2014) acreditam que o professor passa a realizar com maior autonomia a análise de seu contexto e articulação teórico-reflexiva, permitindo-lhe avaliar, revisar e ampliar suas ações docentes, fortalecendo assim o seu processo de autoria.

As vantagens de se considerar o contexto e a coletividade no processo autoral do professor também foram apontados por Sales (2009), ao defender que à medida que o professor revisita sua própria história e percebe como ela se conecta com outras histórias e contextos sociais e culturais. Emerge aí uma postura autoral. Para a pesquisadora, a autoria se legitima na ruptura dos conceitos que a enquadra como produção plena dos autores e passa a ser reconhecida como obra coletiva, múltipla, incompleta e mutante.

Nesse sentido, apontamos que estar imerso em um contexto criativo que fortaleça os laços de coletividade com os pares contribui para o desenvolvimento da autoria docente. Contudo, além de estar imerso em um ambiente que incentive a criação, é necessário que o docente seja comprometido com a sua formação, perfazendo o comprometimento como coadjuvante para a autoria docente. 


\section{Desenvolvimento Profissional}

O compromisso do docente com o seu fazer pedagógico e sua formação se traduz em desenvolvimento profissional. De acordo com Day (2003), o desenvolvimento profissional é o processo pelo qual os professores reveem, renovam e desenvolvem o seu compromisso como agentes de mudança. Assim, o professor que se desenvolve é aquele que está implicado com o seu contexto e com todos os atores, de forma a melhorar constantemente sua realidade.

O desenvolvimento profissional, segundo Mockler (2011), como parte da identidade docente, é dinâmico, emergente, multidimensional e fluído, sendo constituído a partir das experiências pessoais do professor, seu contexto profissional e engajamento político. Acrescenta-se a ideia de 'moral purpose' que, segundo o autor, configura-se como uma liderança moral e educacional que deseja fazer a diferença na vida dos estudantes, traduzindo-se na prática como um professor pró-ativo. Concepção semelhante é apontada por Contreras (2012), ao explicar que a profissionalização do professor pode ser compreendida em três dimensões: i) a obrigação moral, pois o professor está comprometido com todos os seus alunos em seu desenvolvimento como pessoas; ii) o compromisso com a comunidade, considerando que as práticas profissionais docentes não são isoladas e sim constituídas no coletivo; e iii) a competência profissional, que, ao transcender a racionalidade técnica da formação, configura-se como "competências profissionais complexas que combinam habilidades, princípios e consciência do sentido e das consequências das práticas pedagógicas" (p. 83).

A ideia de desenvolvimento profissional com o professor que se enxerga como um agente de mudança, pró-ativo e com desejo de fazer diferença na vida dos estudantes conversa com a motivação intrínseca que soma aos elementos que podem ser a origem da autoria docente. Nesse sentido, acreditamos que, dependendo do compromisso com o seu desenvolvimento profissional, o professor pode desencadear mais ou menos processos autorais em um dado contexto criativo.

Considerando um docente compromissado com o seu desenvolvimento profissional, Maia (2017) explica que, em uma ação formativa, esse professor 
consegue articular novos conhecimentos em sua prática docente e tenta incluir novas metodologias em seu repertório pedagógico. Tais ações irão resultar no investimento do professor em seu desenvolvimento profissional e em sua prática. Nesse processo, o docente se torna responsável por levar o novo conhecimento para outro contexto (sua sala de aula ou escola) e assume um risco ao modificar suas estratégias e inovar em relação ao seu conhecimento anterior. Durante esse movimento, os professores se constituem como autores, pois sentem a necessidade e têm a iniciativa de modificar o seu contexto, mobilizando o compromisso que tem com seu fazer pedagógico e a sua criatividade ao propor inovações em sua realidade. Nesse sentido, o professor se torna autor, também por se sentir implicado ou por responsabilizar-se pelo seu contexto diante da consciência de novos saberes.

A relação entre a autoria e o desenvolvimento profissional pode ser ampliada se considerarmos ainda a autonomia. Segundo Contreras (2012), a autonomia docente é formada pelos aspectos pessoais ou o compromisso do professor; pelos aspectos de relacionamento pessoal e social em seu contexto de trabalho; e ainda, pelas tentativas de compreensão e equilíbrio social com a defesa de valores educativos. Para o autor, a autonomia também é a capacidade que o professor tem de resolver criativamente as situações-problemas para a realização de práticas educativas planejadas e o processo coletivo dirigido à transformação das condições sociais do ensino.

O entendimento do autor nos permite elencar alguns elementos de como a autoria docente dialoga com a autonomia. Antes de tudo, ambas são construídas socialmente. Como vimos, o professor não nasce autor, mas ele pode desenvolver sua autoria conforme consegue mobilizar ao longo de sua formação e carreira aspectos externos (contextuais e coletivos) que podem criar condições propícias para que se constitua como docente autor.

Da mesma forma, para Contreras (2012, p. 216) “a autonomia não é uma definição das características dos indivíduos, mas a maneira que estes se constituem pela forma de se relacionarem". Assim, conforme em seu desenvolvimento profissional o professor consegue fortalecer a sua autonomia, também estará ampliando o seu processo de autoria. Isso nos leva a crer que a autonomia dentro do desenvolvimento profissional impulsiona a autoria. O professor não pode ser 
autor se em sua prática profissional não for um sujeito autônomo, conforme a perspectiva de Contreras.

Incorporamos também ao tema do desenvolvimento profissional e autoria como este se implica à reflexão docente. De acordo com Schön (2000), a ideia do profissional reflexivo é uma resposta à formação profissional baseada na racionalidade técnica. Sob essa ótica, os profissionais são formados para solucionar problemas instrumentais, e, no caso do professor, sua prática profissional é limitada às aplicações de técnicas educacionais pré-formatadas.

No entanto, quando o desenvolvimento profissional está pautado na prática reflexiva, o professor pode se deparar com situações de seu contexto que transcendem aquilo que aprendera em sua formação. Por exemplo, pode estar diante de um caso único e pode ser que não encontre respostas em suas técnicas habituais de ensino. Para o docente que se depara com situações como estas, Schön (2000, p.17) responde que "se ele quiser tratá-lo de forma competente, deve fazê-lo através de um tipo de improvisação, inventando e testando estratégias situacionais que ele próprio produz". Perguntamo-nos o que seria isso, se não, autoria docente.

Segundo Pimenta (2008. p.21), a reflexão contribui para "formar profissionais capazes de ensinar em situações singulares, instáveis, incertas, carregada de conflitos e de dilemas, que caracteriza o ensino como prática social em contextos historicamente situados". Contribuindo para a visão de Pimenta, Contreras (2010) considera que a perspectiva do docente como profissional reflexivo permite construir a noção de autonomia como forma de intervenção nos contextos concretos da prática em que as decisões são resultadas da complexidade, ambiguidade e conflituosidade do contexto. Percebemos que, para os autores, a capacidade de criar estratégias ou práticas educacionais em um contexto de incerteza que tangencia um professor reflexivo e autônomo desencadeia em processos de autoria docente. Assim, a autonomia e reflexão são elementos inerentes ao percurso formativo e à atuação do docente incorporada à dimensão Desenvolvimento Profissional.

Ainda na importância de pensarmos o compromisso do docente com o seu desenvolvimento profissional como originário da autoria, voltamo-nos para as 
formas em que em o cotidiano do professor pode estar imbuído de autoria, no sentido de estimular o desejo e a necessidade da formação continuada, do trabalho coletivo e da reflexão.

Segundo Pérez Goméz (2010), quando vivemos intensamente o cotidiano, com suas contradições e surpresas, construindo novos pensamentos, sentimentos e ações, toda a experiência se torna transformativa. Para o autor, "a reconstrução do conhecimento requer que os docentes revisem e questionem as mesmas imagens, ideias e práticas que desenvolvem em sua prática cotidiana” (p. 47, tradução nossa $)^{8}$. O professor, ao tomar consciência sobre o desenvolvimento de seu processo de ensino, pode problematizar as teorias e visões de mundo que estão implícitas no cotidiano. É por esse olhar que tem a possibilidade de questionar as crenças e os valores que representam a sua prática, além de desenvolver processos ou estratégias de ações de inovação pedagógica.

Nesse sentido, o professor se educa e se autoriza como autor ao implicar-se e refletir sobre o processo educativo dos outros. É tomando consciência de sua atividade cotidiana e refletindo sobre sua prática que o professor consegue construir estratégias para atuar em zonas incertas da prática educacional, acionando elementos da autoria e da criatividade docente. A imagem a seguir anuncia os elementos implícitos nessa dimensão e suas relações.

\footnotetext{
8 "la reconstrucción del conocimiento práctico requiere que los docentes revisen y cuestionen las mismas imágenes, ideas y prácticas em em su actividad cotidiana".
} 


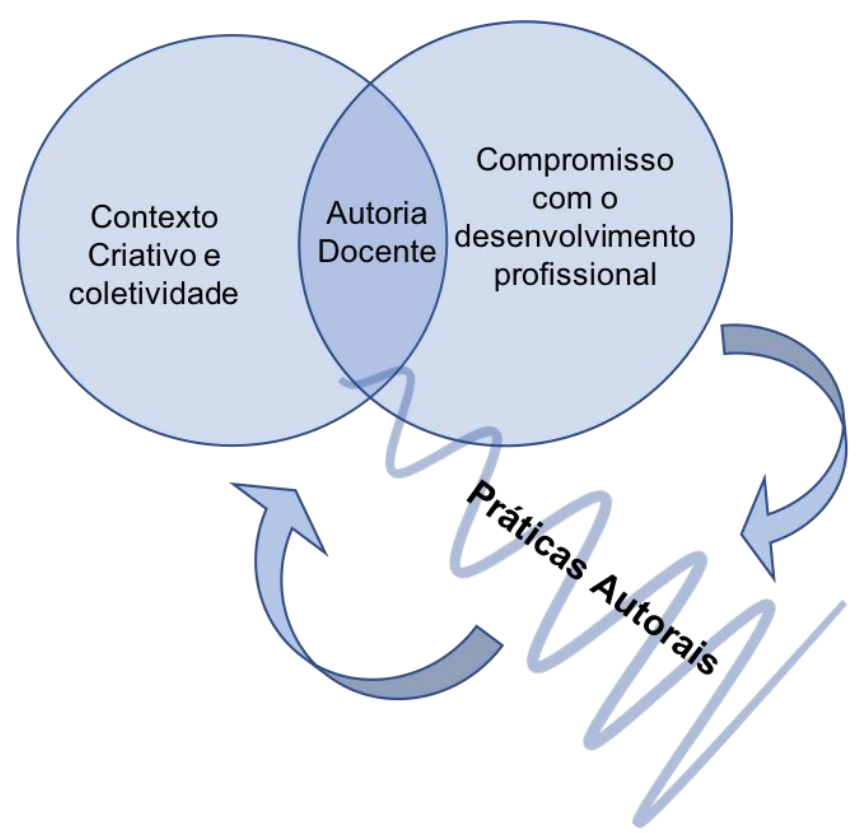

Figura 2 - Formação da Autoria Docente. Elaboração própria.

Ao tentar refletir sobre as origens da autoria docente percebemos que elas são interligadas, sendo necessário compreendermos o conceito de autoria docente como um continuum em que as origens e seus conceitos-chaves conversam entre si, criando a autoria docente.

Na figura 2 é possível visualizar a concepção de autoria que defendemos. O professor, ao estar imerso em um contexto criativo e colaborativo e sendo compromissado com o seu desenvolvimento profissional, tem um ambiente fértil para a autoria docente, como pode ser observado na intercessão. Podemos perceber que as práticas autorais se comportam como uma espiral, isto é, as práticas aumentam conforme são retroalimentadas pelo contexto e pelo desenvolvimento profissional do docente, compondo assim um movimento circular virtuoso.

Os resultados da nossa análise documental apresentam um quadro composto por algumas linhas de raciocínio que se repetem. Em primeiro lugar, destaca-se a existência de uma relação entre criatividade pessoal e contexto no qual o professor pode estar inserido. As relações sociais que o docente pode estabelecer com a coletividade escolar e particularmente com seus pares constituem uma contribuição fundamental para sua criatividade e, portanto, sua produção autoral. A partir desse dado, podemos inferir que um primeiro elemento que define o professor-autor é a 
propensão para valorizar as ideias alheias, observar o que a coletividade tem para oferecer e dialogar com os colegas em busca de soluções alternativas.

Em segundo lugar, há um elemento que podemos chamar, de acordo com Ryan e Decy (2000), de motivação intrínseca, ou seja, um desejo interno do sujeito de melhorar sua própria prática e de se desenvolver pessoalmente e profissionalmente. Como vimos, as pesquisas mostram que o compromisso do professor com o seu desenvolvimento é um fator crucial para desencadear os processos autorais. Entendemos, também, que quanto mais o professor-autor amplia a sua produção autoral mais ele se torna autônomo, gerando um círculo virtuoso de práticas fundamentadas em autoria/autonomia. A autonomia, sendo o pressuposto para novas buscas de sentido, impulsionadas pela auto-reflexão do sujeito e sua auto-percepção. Nesse movimento, o professor se torna autor na medida em que está disposto a abandonar práticas consolidadas, para abraçar o novo, arriscando o novo.

Parece-nos possível concluir que o professor-autor é um sujeito impulsionado pela curiosidade de conhecer o que os outros fazem para se inspirar e melhorar sua prática e capaz de ousar para trilhar caminhos desconhecidos, que podem trazer um desenvolvimento e uma melhora de suas práticas pedagógicas. É esse o profissional que na cultura digital pode aproveitar da infinita variedade de recursos, mas é também o profissional que com poucos recursos disponíveis consegue reinventar suas propostas didáticas, refletindo sobre o contexto.

Reconhecemos que identificar elementos que contribuem para o processo autoral do professor não significa negar aspectos políticos e de infraestrutura que podem ter impactos positivos ou negativos no trabalho desenvolvido pelo docente, assim como no tipo de prática autoral em que possa ser gerado, ou até mesmo a sua falta.

A prática docente enfrenta enormes desafios, seja na formação do professor, na infraestrutura tecnológica das escolas, na elaboração e implantação de políticas públicas com impactos significativos no cotidiano escolar, entre outros aspectos. No campo dos estudos sobre as TIC na escola, presenciamos na última década políticas como o Programa Nacional de Tecnologia Educacional (Proinfo) e o 
Programa um computador por aluno (Prouca) que, dentre outras ações, tinham o objetivo de equipar as escolas com computadores e internet de banda larga e fornecer dispositivos móveis para os alunos, como o laptop.

Segundo Martins e Flores (2015), ao fazer um levantamento sobre teses e dissertações que tinham como tema a política do Proinfo, o que se percebeu ao longo dos anos foi uma trajetória de insucesso e dificuldades na implantação do programa. A pesquisa apontou que os investimentos em programas de formação do professor para o uso das TIC em sua prática educacional foram insuficientes, não resultando em integração significativa das tecnologias no espaço escolar ou na prática de ensino. Além disso, os equipamentos recebidos pelas escolas se tornaram obsoletos, sendo agravada pela falta de equipe de apoio para a manutenção e atualização destas tecnologias.

Também com relação ao Prouca, Echalar e Peixoto (2017) defendem que o processo de inclusão digital via ambiente escolar deixou uma grande lacuna no fundamento pedagógico, refletido pela precária infraestrutura tecnológica e pelo processo de formação de professores. Ainda para as autoras, o acesso ao laptop não garantiu as mesmas oportunidades de aprender e participar do processo de imersão digital para todos os estudantes.

Tais políticas, que foram direcionadas às escolas de diferentes contextos e regiões do país, levam-nos a refletir que o professor não pode ser considerado refém de um discurso salvacionista e solitário na educação, como se o desenvolvimento de práticas autorais com ou sem o uso da tecnologia dependesse única e exclusivamente dele. Entendemos que, ao tratar da prática pedagógica, inclusive da autoria docente, existem múltiplas variáveis sociais, econômicas, culturais e de formação que se relacionam com esse fazer da prática educativa, contudo, nossa intenção foi levantar alguns fatores que pudessem ser importantes para o desenvolvimento do processo autoral do professor.

Outro elemento que acreditamos contribuir para a construção de nossa abordagem teórica é a competência digital dos professores. Defendemos que o desenvolvimento das competências digitais pode influenciar a criação de práticas pedagógicas com os RED. 


\section{4}

\section{Do conceito de competência digital}

O desenvolvimento de competências para que professores consigam integrar as TIC ao currículo e aos processos de ensino, visando ampliar as oportunidades de aprendizagem aos estudantes, tem alcançado um papel cada vez mais central quando falamos de uma educação democrática e inclusiva no século XXI (BONILLA; PRETTO, 2011; BANNEL et al., 2016). Pischetola (2016) alerta que a introdução da tecnologia como suporte educacional pode ser um fator de desestabilização na escola. A autora evidencia os receios que os professores têm de não possuírem competências para o uso das TIC em sala de aula, pela dificuldade de mudar as práticas de ensino e de aprendizagem e pela falta de reconhecimento que existe sobre a necessidade de integrar as tecnologias no cotidiano escolar.

Analisar as diferenças entre as atividades realizadas com as TIC pelos docentes nos leva a inferir que existe uma lacuna de formação para a integração de tecnologias nas práticas pedagógicas dos professores (PISCHETOLA, 2016) e seu respectivo desenvolvimento de competências. A chave para entender essa lacuna está no contraste do nível de competências necessárias para cada atividade, visto que no seu desenvolvimento em sala de aula são necessários também conhecimentos técnicos da tecnologia, enquanto que para atividades de planejamento demandam-se conhecimentos sobre as possibilidades pedagógicas das TIC (BRASILINO et al., 2018). De acordo com Insterfjord e Munthe (2016), o conhecimento técnico de como se utilizar as TIC faz parte das competências digitais do professor e diz respeito também à compreensão das condições necessárias para utilizar uma tecnologia específica no ensino.

Ao discutir sobre a relação entre as atividades educacionais com as tecnologias e a formação do professor, deparamo-nos frequentemente com os conceitos de letramento ou literacia digital e competência digital. O letramento digital pode ser compreendido como um movimento de plena participação de leitura e escrita com apropriações tecnológicas envolvendo práticas sociais e culturais (PISCHETOLA, 2006; BUZATO, 2010). Já as competências digitais podem ser 
definidas como um conjunto de conhecimento, habilidades, atitudes e estratégias que possibilite a realização de diferentes atividades socialmente valorizadas com uso das TIC, tais como a resolução de problemas, gerenciamento da informação, colaboração, criação e compartilhamento de conteúdo, entre outros (FERRARI, 2012).

De forma a diferenciar tais termos, Spante et al. (2018) explica que o conceito de letramento digital é mais antigo e começa a aparecer na literatura em 1997, enquanto as primeiras pesquisas que adotam o conceito de competência digital datam de 2010. Quanto às diferenças de conceituação, as autoras explicam que tanto pesquisas como documentos de políticas públicas têm compreendido o letramento digital como habilidades orientadas ao "como fazer"; perspectiva que compreende o letramento digital como uma abordagem reflexiva de "interrogar o mundo"; capacidades individuais de viver, aprender e trabalhar em uma sociedade digital; e capacidades em relação a comunicação, colaboração, aprendizagem para o uso de ferramentas digitais em tomadas de decisão. Todas estas visões indicam que o conceito de letramento digital não é consensual, sendo passível de diferentes interpretações.

Com relação ao conceito de competência digital, as autoras verificaram que este é suportado por significados e definições utilizadas em políticas públicas e é empregado para o uso da tecnologia para propósitos profissionais em vários contextos. No contexto específico de formação de professores tem sido compreendido como as habilidades individuais do docente para implementar tecnologias em atividades de aprendizagem para melhorar o desenvolvimento do conhecimento do estudante e sua compreensão.

Spante et al. (2018) também reconhecem que ambos os conceitos são amplamente utilizados em pesquisas e em documentos de políticas públicas sem maiores preocupações com a sua definição. Em muitos casos existem definições de competência digital que envolvem letramento digital e vice e versa.

No presente estudo, optamos por trabalhar com o conceito de competências digitais. Petterson (2018) explica que ao discutir o tema das competências digitais devemos partir do princípio que existe uma diferença entre os tipos de competências 
requeridos de um cidadão comum e os aspectos pedagógicos da competência digital que são necessários aos professores. Para o autor, recentes pesquisas têm demonstrado que as competências digitais dos docentes exigem habilidades mais complexas, comparadas com as de outras áreas da sociedade. Isto porque os professores estão inseridos em um sistema organizacional tradicional e heterogêneo que aumentam a complexidade quando a competência é promulgada em ambientes educacionais.

Em sua revisão sistemática de literatura, Petterson (2018) verificou que as pesquisas sobre as competências digitais dos docentes têm caminhado em quatro direções, a saber: i) pesquisas sobre documentos e direcionamento de políticas, abrangendo a promoção do desenvolvimento de competências digitais no contexto educacional para a mudança e inovação; ii) infraestrutura organizacional, que discute a importância de mudanças culturais na escola, assim como a necessidade da instituição ter estrutura tecnológica para assim poder desenvolver competências digitais nos docentes e práticas educacionais integradas à tecnologia; iii) liderança estratégica, que aborda questões sobre as ações de líderes escolares para concretizar as políticas de desenvolvimento de competências digitais em seus contextos e iv) e o ensino e práticas de professores, que discorrem sobre os aspectos pedagógicos das competências digitais de professores e como estes as utilizam em suas práticas pedagógicas. Neste último tópico estão as pesquisas sobre o impacto das competências digitais dos professores na integração de tecnologias na escola e o uso pedagógico das TIC; a importância de diferentes formas de desenvolvimento profissional docente para a melhor compreensão do uso pedagógico das tecnologias digitais; e o desenvolvimento destas competências digitais durante a formação de professores.

Com relação ao que são essas competências digitais e como elas devem ser desenvolvidas em contextos educacionais, as pesquisas indicam que não existe um consenso (PETTERSON, 2018). Alguns caminhos para contornar essa situação têm sido apresentados em investigações que se propuseram a criar modelos formativos para o desenvolvimento de competências digitais em professores iniciantes (FERNÁNDEZ e PÉREZ, 2018; INSTERFJORD e MUNTHE, 2016; 
GUDMUNDSDOTTIR e HATLEVIK, 2017) e em serviço (AL KHATEEB, 2017; BENALI, KADDOURI, AZIMANI, 2018).

Os estudos acima mencionados apontam que os cursos para a formação de professores não abordam suficientemente o uso das tecnologias no processo de ensino de forma a possilitar a criação de práticas pedagógicas mais significativas para a aprendizagem dos alunos, e, quando o fazem, é dada maior atenção em desenvolver com os futuros professores a compreensão e a consciência de como a tecnologia pode contribuir para o alcance dos objetivos da aprendizagem, do que em desenvolver competências tecnológicas para o uso das TIC na educação (INSTERFJORD e MUNTHE, 2016; GUDMUNDSDOTTIR e HATLEVIK, 2017). De fato, somente a habilidade tecnológica não é suficiente para desenvolver um conhecimento profundo de como os professores podem efetivamente integrar as TIC em atividades em sala de aula, de forma a ampliar a aprendizagem dos estudantes. Nesse sentido, o desenvolvimento de competências digitais dos professores está além do domínio técnico da TIC ou do reconhecimento do potencial da tecnologia nas práticas pedagógicas e precisa ser compreendido como um conjunto de conhecimento, habilidades, atitudes e estratégias (competências) que possibilitem a realização de diferentes atividades socialmente valorizadas com uso das TIC.

Existem quadros de referência (frameworks) reconhecidos de integração de tecnologias em contextos educacionais que podem oferecer um norte quanto aos tipos de competências que precisam ser desenvolvidas pelos professores para que possam elaborar práticas pedagógicas com o uso das tecnologias. Utilizado desde 2006, o Technological Pedagogical Content Knowledge Model (TPACK) (MISHRA e KOEHLER, 2006) identifica as competências digitais dos professores como uma intercessão de três fontes de conhecimento: conteúdo, pedagógico e tecnológico, podendo as intercessões das competências digitais serem modificadas (Pedagógico e tecnológico ou tecnológico e conteúdo, entre outras intercessões) de acordo com a proposta pedagógica do professor.

Um quadro de referência mais recente de competências digitais para os docentes foi desenvolvido pelo European Commission's Joint Research Centre (JRC), nomeado como Quadro de Competências Digitais para Educadores 
(DigCompEdu). Este quadro é direcionado para professores de todos os níveis educacionais e foi pensado para que os docentes avaliem e desenvolvam sua competência digital pedagógica, considerando como as tecnologias podem ser utilizadas para melhorar e inovar no ensino, aprendizagem e avaliação. Segundo Redecker (2017), o quadro de referência foi concebido a partir de uma série de discussões e deliberações com especialistas no campo das tecnologias digitais e a educação, e sintetiza todos os modelos e instrumentos existentes em um quadro genérico de referência. Como pode ser observado na figura 3, o documento propõe 22 competências que foram organizadas em 6 áreas, a saber: 1) ambiente profissional - uso das TIC para o desenvolvimento profissional do educador e para o bem coletivo da instituição; 2) competências necessárias para usar, criar e compartilhar recursos educacionais digitais; 3) gestão das TIC no ensino e aprendizagem; 4) uso de estratégias digitais para processos de avaliação; 5) potencial das TIC para estratégias de ensino e aprendizagem centrada no aprendente; e 6) competências pedagógicas específicas necessárias para promover competências digitais dos aprendentes (REDECKER, 2017). Além disso, o quadro descreve os níveis de cada competência, podendo o professor se encontrar no nível $\mathrm{A} 1$, que corresponde ao recém-chegado, ao nível $\mathrm{C} 2$, pioneiro. Tais níveis permitem a avaliação, desenvolvimento e acompanhamento da proficiência dos docentes.

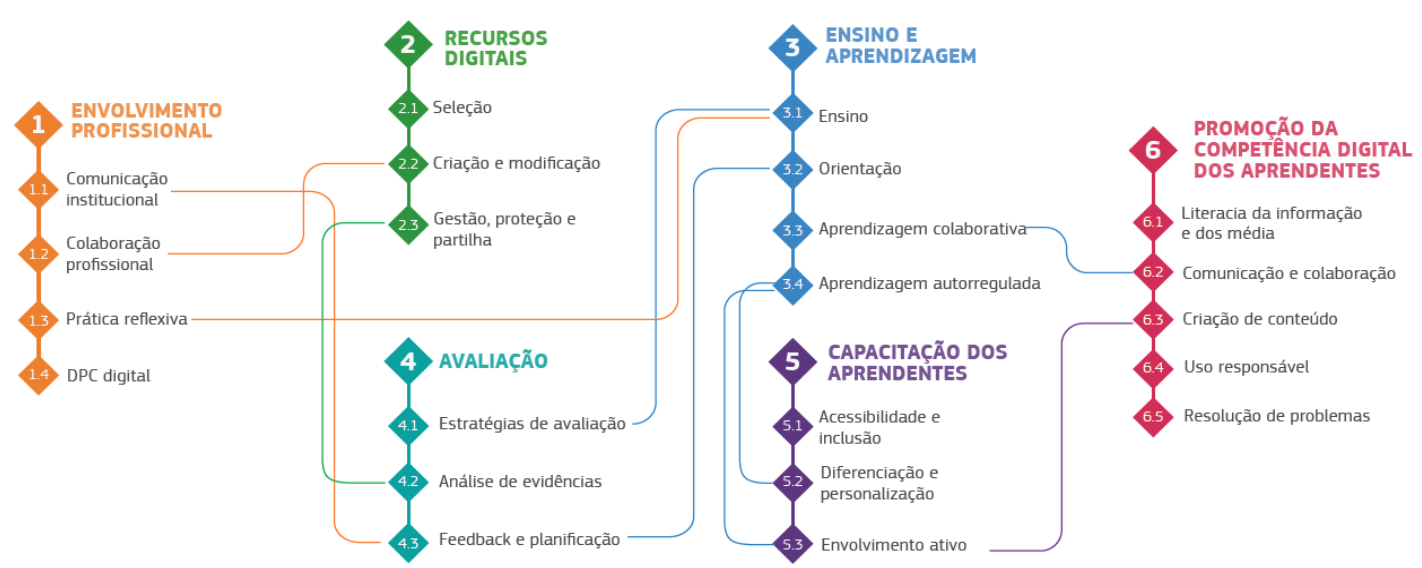

Figura 3 - Quadro DigCompEdu. Fonte: Lucas e Moreira, 2018. 
Na presente pesquisa utilizaremos o quadro de referência do DigCompEdu como apoio para compreensão de algumas de nossas questões de estudo, quanto a relação entre as competências digitais que são agenciadas pelos docentes e suas práticas autorais com os recursos educacionais digitais.

Acreditamos que o digital tem grande potencial para a promoção de um espaço de experimentação e de criação do conhecimento e, exatamente por isso, se voltarmos para as questões norteadoras deste estudo veremos que as competências digitais são uma das colunas que suspeitamos sustentar as práticas dos professores com os recursos educacionais. Nossa hipótese é que quanto mais desenvolvidas as competências digitais dos professores, maior será o uso dos recursos educacionais, e, por conseguinte, maiores criações e adaptações dos recursos. Segundo Pretto (2012), os recursos educacionais, quando abertos, além de possibilitar a distribuição gratuita de conteúdos educacionais, trazem a oportunidade de viabilizar que professores e alunos possam se apropriar dos recursos em rede e ser produtores de conhecimento e culturas.

Para Veloso e Bonilla (2018), a autoria docente diz respeito à criação de atos de currículo condizentes com o contexto da cibercultura no cotidiano escolar. As autoras explicam que refletir sobre a autoria implica considerarmos as relações que se estabelecem entre tecnologia, conhecimento e autoria em um determinado tempo histórico. Sendo assim, ponderar sobre a autoria docente em nosso espaço tempo envolve discorrermos sobre a cultura contemporânea. O mesmo entendimento é levantado por Souza et al. (2011), por defender que é no contexto da conectividade e do compartilhamento de recursos que a autoria tem maior possibilidade de contribuir para inovações pedagógicas sob a forma de autoria coletiva.

Mas de que forma o professor, ao ter competências digitais desenvolvidas, pode potencializar seu processo autoral? Antes de tudo, cabe-nos reforçar que somente utilizar a tecnologia não garante o surgimento da autoria, pois esta precede o digital. Vimos que as dimensões da autoria docente não são dependentes do uso da tecnologia, no entanto, o professor ao desenvolver práticas pedagógicas em um ambiente imerso por tecnologia pode potencializar esse processo. 
Ao mapear como o professor se reconhece autor na cultura digital,Veloso e Bonilla (2018) verificaram que esse movimento de criação do professor é vinculado à internet, embora esteja majoritariamente associado como espaço de pesquisa. Também apareceram as mobilizações internas e externas do professor na construção de sua autoria contextualizada na cultura digital. Sendo a externa a própria cultura com sua infinidade de informações; e a interna a inserção dos alunos nessa mesma cultura que confronta o papel e o conhecimento do docente, demandando uma mudança de postura. E, por fim, apresentam a rede líquida de criação que seria o aumento das circulações de ideias externas e internas ao ambiente escolar por meio presencial ou por meio das tecnologias digitais que potencializam as criações coletivas.

Souza et al. (2011) enxergam nas ferramentas de autoria, tais como fóruns, wikis, blog, rede social, entre outros, a possibilidade de compreendermos como o digital pode potencializar a autoria dos professores. Os autores argumentam que, neste contexto, a prática da autoria traz para o ambiente escolar formas de ensinar e de aprender mais colaborativas, estando implícito na autoria docente a autoria coletiva. Os autores se apropriam do conceito do professor hacker (PRETTO, 2012) ao apontar que o professor autor deve pleitear valores como colaboração, conhecimento, liberdade e compartilhamento valorizando a criação coletiva cada vez mais.

Os eixos abordados neste capítulo (i) contexto social e tecnológico; (ii) recursos educacionais, (iii) autoria docente e (iv) competências digitais se entrelaçan na rede desta pesquisa, tornando-se indissociáveis da metodologia e da interpretação dos dados oriundos do estudo. 


\section{3}

\section{Metodologia}

No presente capítulo descrevemos e justificamos as opções metodológicas realizadas que sustentam a investigação deste trabalho.

O capítulo foi estruturado com uma breve explicação de nossas orientações epistemológicas do fazer ciência, seguido pela explicação da natureza do estudo. Apresenta-se também a descrição dos participantes da pesquisa, os instrumentos utilizados para a produção dos dados e os procedimentos realizados para a sua análise.

\section{1}

\section{O fazer ciência e o percurso da pesquisa}

Para alcançarmos o objetivo desta pesquisa, buscamos traçar uma trilha metodológica em que fosse possível conceber o objeto como um sistema de relações em um contexto. A pesquisa parte da crença de que não é possível investigar as práticas autorais de professores com o uso de recursos educacionais distanciandoas do contexto em que estas são desenvolvidas. Ao mesmo tempo, acreditamos que o percurso de pesquisa não pode ser linear ou estanque. É preciso respeitar e valorizar os movimentos de idas, paradas e retornos que estão implícitos no fazer ciência. Assim, buscamos neste tópico apresentar nossa compreensão de ciência e sua influência no percurso metodológico seguido.

Assumimos que a forma que compreendemos o conhecimento intervém em nossa trilha metodológica, sendo, antes de tudo, uma questão epistemológica. Melucci (2005) defende a necessidade de uma virada epistemológica de modo a questionar as bases fundamentais nas quais a pesquisa tradicional está fundamentada. O autor aponta a prática reflexiva como um caminho para se fazer pesquisa considerando a virada epistemológica, assumindo que o campo ou a realidade social interage com o observador, visto que "os 'atores sociais' somos, pois, nós mesmos, porque 'os outros', 'os sujeitos' ou 'objetos' da pesquisa estão 
em relação conosco, pelo menos, quando nós estamos em relação com eles" (p. 318).

Para essa pesquisa, temos como pressupostos que o objeto não está isolado e é interpretado como um sistema de relações; o pesquisador não é neutro em relação ao seu campo de estudo, embora isso não se configure total subjetividade no processo de reflexão e interpretação do seu objeto; e o processo metodológico não acontece de forma linear, é complexo.

Em nosso caso, optamos por trazer a reflexividade no desenvolvimento da metodologia da pesquisa e dos instrumentos para a construção de dados. Lembramos que as técnicas de pesquisa são um caminho em que se decorre a prática reflexiva (MELUCCI, 2005) e que são nas pesquisas de cunho qualitativo que mais facilmente se pode emergir uma consciência mais clara dos novos problemas epistemológicos. Considera-se ainda que, visto do ponto de vista da comunidade científica, "são menos legitimadas para enfrentar um dos nós centrais do paradigma do dualista moderno, isto é, a mediação necessária entre ator e sistema, entre estrutura e ação" (p. 323).

Partindo da ideia de sistema e reflexividade nos sentimos livres para assumir que o desenho metodológico dessa investigação não precisava ser linear. Morin (2005) explica que na perspectiva clássica o método é encarado como um corpus de receitas com aplicações quase mecânicas. Ao mesmo tempo o autor exorta-nos a considerar a construção do método como espaço de estratégia, iniciativa, invenção e arte. Nas palavras do autor, "a arte é indispensável para a descoberta científica, visto que o sujeito, suas qualidades e estratégias terão nela papel muito maior e muito mais reconhecido" (MORIN, 2005, p. 338). Apropriando-nos da ideia de método como espaço de estratégia e inventividade e como modelo não linear de fazer ciência, cientes que a pesquisa qualitativa nos abre maior espaço para uma virada epistemológica, apresentamos o desenho metodológico adotado nesta pesquisa.

A figura 4 nos permite acompanhar as relações e os movimentos de idas e vindas que perpassam um processo de pesquisa. 


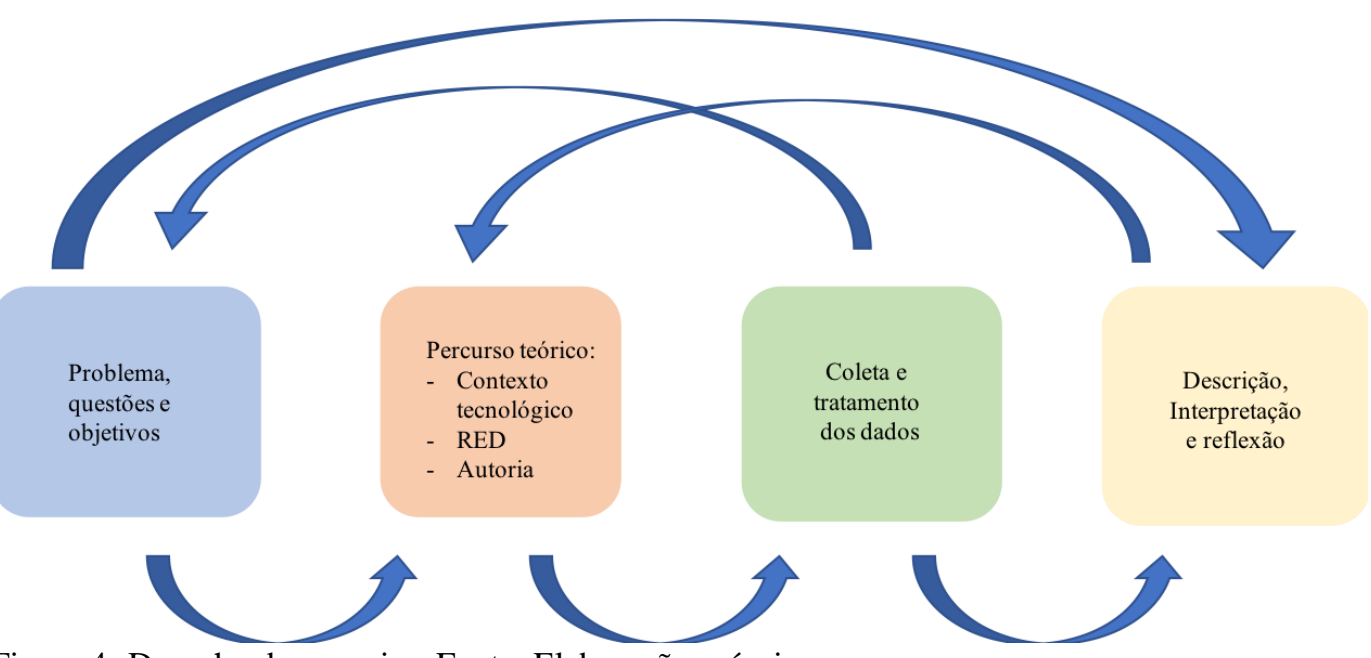

Figura 4- Desenho da pesquisa. Fonte: Elaboração própria.

Procuramos, desse modo, exaltar a complexidade no processo de fazer ciência, pois enquanto ao mirar unicamente os quadrados poderiam inferir as etapas como um modelo científico linear, as setas demonstram os momentos de dúvidas, recuadas, inventividade, desafios e interatividade que estão presentes em uma investigação qualitativa. Observando as direções das setas podemos tentar compreender as dinâmicas que se estabelecem no decorrer da pesquisa, indicando, por exemplo, que o problema, questões e objetivos precisam dialogar em diferentes fases do processo. Ao mesmo tempo, o percurso teórico está interligado com os objetivos, metodologia, tratamento, análise de dados e descrição, interpretação e reflexão e influencia as escolhas em cada um desses processos. Destarte, compreender o caráter relacional e dinâmico da pesquisa é essencial se quisermos respeitar e ressaltar o caminho do pesquisador em uma abordagem reflexiva.

Nesse sentido, fazer ciência, para nós, é um movimento interativo, complexo, e por vezes "desordenado", o que nos leva a criar estratégias (MORIN, 2005) diferenciadas para avançarmos. Dentre estas, o reconhecimento da aleatoriedade no objeto e no sujeito (tomada de decisões), sendo esse processo evidente em nossa trajetória. 


\section{2}

\section{Natureza da pesquisa: um estudo de caso}

Delineado o objetivo central da pesquisa "descrever e compreender se e como os recursos educacionais digitais são utilizados pelos professores para o desenvolvimento de práticas autorais em seus contextos profissionais" começamos a refletir sobre o tipo de pesquisa que seria feito, em qual campo e com quais sujeitos. Nosso interesse era chegar aos professores que já utilizavam os recursos educacionais digitais em sua prática profissional e que, se possível, fossem professores de diferentes regiões do país, com variados tipos de experiências e perspectivas sobre o uso do RED.

Tendo em vista tais pressupostos, realizamos um levantamento simples de repositórios de recursos educacionais digitais disponibilizados para professores. Por meio do site de buscas Google e utilizando as palavras chaves: repositórios de recursos educacionais digitais e repositório de recursos educacionais abertos encontramos 57 repositórios de RED. Em um segundo momento, fizemos uma triagem dos repositórios brasileiros que se relacionavam com a temática do estudo, excluindo os repositórios de teses e dissertações, artigos científicos e outros relacionados com o ensino superior. Também foram excluídos repositórios de RED ou REA internacionais, ainda que direcionados à educação básica, por acreditarmos que os repositórios produzidos no contexto brasileiro se aproximariam mais da realidade de cada professor.

Como descrito na tabela 1, mapeamos 32 repositórios de recursos direcionados à educação básica. De posse da lista, iniciamos um trabalho de aproximação e contato com as instituições que gerenciavam os repositórios, o que se revelou uma tarefa morosa e por muitas vezes angustiante. Entramos em contato via email ou telefone com 32 repositórios, tendo 15 repositórios respondido ao contato inicial. Ressaltamos aqui a dificuldade de respostas com os repositórios geridos pelo Ministério da Educação, visto que repositórios como a Plataforma MEC RED despertavam nosso interesse, em especial por atenderem professores de 
todo o país. Contudo, após diversas ligações e e-mails conseguimos apenas números de protocolos.

\begin{tabular}{|c|c|c|c|}
\hline Repositório & $\begin{array}{c}\text { Retornou ao } \\
\text { contato }\end{array}$ & $\begin{array}{l}\text { Viabilizou a } \\
\text { pesquisa }\end{array}$ & Justificativa \\
\hline Currículo Mais & Sim & Não & Pesquisa não autorizada \\
\hline Educopédia & Sim & Não & Desistência \\
\hline Escola Digital & Não & Não & \\
\hline Portal do Professor/MEC & Não & Não & \\
\hline $\begin{array}{l}\text { Repositório Secretaria de } \\
\text { Educação da Bahia }\end{array}$ & Sim & Não & Pesquisa não autorizada \\
\hline M3 - Unicamp & Sim & Não & $\begin{array}{l}\text { Não possuía cadastro dos } \\
\text { professores }\end{array}$ \\
\hline RIVED/MEC & Não & Não & \\
\hline Edumatec UFGRS & Sim & Não & $\begin{array}{lr}\text { Não possuía } & \text { cadastro } \\
\text { atualizado } & \text { dos } \\
\text { professores } & \end{array}$ \\
\hline $\begin{array}{l}\text { Repositório Secretaria de } \\
\text { Educação do Paraná }\end{array}$ & Sim & Sim & \\
\hline Fábrica Virtual UFRGS & Não & Não & \\
\hline Repositório Noas & Sim & Não & $\begin{array}{l}\text { Por ser repositórios de } \\
\text { recursos abertos, não } \\
\text { possuía cadastro dos } \\
\text { usuários }\end{array}$ \\
\hline Sabercom FURG & Não & Não & \\
\hline CDME UFF & Sim & Não & Repositórios inativos, \\
\hline GGTE UNICAMP & Sim & Não & $\begin{array}{l}\text { Não possuía cadastro dos } \\
\text { professores }\end{array}$ \\
\hline Indio Educa & Sim & Não & Repositórios inativos, \\
\hline $\begin{array}{l}\text { Repositório } \quad \text { Colégio } \\
\text { Porto Seguro }\end{array}$ & Sim & Não & $\begin{array}{l}\text { Por ser repositórios de } \\
\text { recursos abertos, não } \\
\text { possuía cadastro dos } \\
\text { usuários }\end{array}$ \\
\hline Mais Mat & Não & Não & \\
\hline LUME UFRGS & Sim & Não & Repositórios inativos, \\
\hline $\begin{array}{l}\text { Repositório } \quad \text { Colégio } \\
\text { Pioneiro }\end{array}$ & Sim & Não & $\begin{array}{l}\text { Por ser repositórios de } \\
\text { recursos abertos, não } \\
\text { possuía cadastro dos } \\
\text { usuários }\end{array}$ \\
\hline ROCA UTFPR & Não & Não & \\
\hline Acervo Digital UFPR & Não & Não & \\
\hline Educapes & Não & Não & \\
\hline $\begin{array}{l}\text { Repositório Secretaria de } \\
\text { Educação de Campinas }\end{array}$ & Sim & Não & Pesquisa não autorizada \\
\hline
\end{tabular}




\begin{tabular}{|c|c|c|c|c|}
\hline Arca Fiocruz & Não & Não & & \\
\hline Rea Paraná & Sim & Não & $\begin{array}{l}\text { Descontinuidade } \\
\text { contato }\end{array}$ & no \\
\hline Repositório UFTPR & Não & Não & & \\
\hline Proedu IFCE & Não & Não & & \\
\hline W3 UFSM & Não & Não & & \\
\hline Riuni Unisul & Não & Não & & \\
\hline Cinted UFRGS & Não & Não & & \\
\hline $\begin{array}{l}\text { Repositório Secretaria de } \\
\text { Educação do Espírito } \\
\text { Santo }\end{array}$ & Sim & Não & $\begin{array}{l}\text { Descontinuidade } \\
\text { contato }\end{array}$ & no \\
\hline Plataforma MEC RED & Não & Não & & \\
\hline
\end{tabular}

Tabela 1 - Mapeamento de Repositório de Recursos Educacionais Digitais. Fonte: Elaboração Própria.

Dentre as justificativas para a não viabilização da pesquisa na maioria dos repositórios contatados, verificamos os seguintes motivos: desinteresse em participar, falta de cadastro dos usuários, repositórios inativos, desistência da participação e não autorização da pesquisa por instâncias superiores.

Ao final da triagem dos repositórios obtivemos a confirmação da participação na pesquisa dos repositórios das secretarias de educação do Paraná, da Bahia e do Espírito Santo. Nesse momento tínhamos a expectativa de realizar um estudo em que tivéssemos a presença de três regiões brasileiras de contextos sociais, culturais e educacionais diferentes. Defendíamos que tais campos diversificados poderiam trazer maior representatividade à pesquisa. Contudo, devido a desistências e ao não envio dos questionários aos professores, a pesquisa foi realizada apenas na região sul, especificamente no estado do Paraná.

Com a segurança do campo de pesquisa, passamos a rever e refletir nossas opções metodológicas, que pelo percurso trilhado já indicava ser de natureza qualitativa. De acordo com Creswell (2012), uma pesquisa de viés qualitativo explora um problema e desenvolve um entendimento detalhado sobre um fenômeno delimitado através de uma extensa coleta de dados. Em nosso caso, procuramos compreender o fenômeno do uso de RED por professores e seus processos autorais com estes usos.

Outra característica da pesquisa qualitativa é o lugar central que o pesquisador ocupa no fazer da pesquisa (STAKE, 2005) e o seu processo de reflexão (MELUCCI, 2005), visto que pressupõe discutir a sua posição na 
investigação, refletindo sobre seus próprios vieses, valores e suposições. Aspectos esses que correspondiam às nossas perspectivas adotadas nesse fazer científico.

Uma vez nos situando metodologicamente como uma pesquisa qualitativa, voltamo-nos para o processo de triagem do campo de pesquisa. A priori, nossa intenção era que os repositórios participantes da pesquisa enviassem aos professores cadastrados na plataforma um questionário de investigação. No entanto, conforme já informamos, de todos os repositórios contatados tivemos efetividade na participação de apenas um: Repositório de Recursos Educacionais da Secretaria Estadual do Paraná.

Tal fato nos instigou a levantar algumas suposições do porquê apenas este repositório específico aceitou participar da pesquisa. Seria a Secretaria do Estado do Paraná mais aberta a pesquisas acadêmicas ou sensível à temática do professor e uso de tecnologias na educação?

A participação de um único repositório na pesquisa, assim como a característica ímpar que aparentava ser o contexto da educação do Paraná nos levou a eleger o estudo de caso como o método de pesquisa qualitativa a ser realizada. Segundo Yin (2001), o estudo de caso é uma estratégia de pesquisa que investiga um fenômeno contemporâneo dentro do seu contexto quando os limites entre o fenômeno e o contexto não são claramente definidos. Este método pode ser utilizado quando deliberadamente queremos lidar com condições contextuais, acreditando que poderia ser pertinente ao fenômeno estudado. O estudo de caso é também a estratégia mais indicada quando estão postas questões do tipo "como" e "por que". Se voltarmos para as questões de estudo, como descritos no quadro 1, perceberemos que este estudo tem a finalidade de explicar e descrever um fenômeno específico, correspondendo ao "como" e ao "por quê" de um fenômeno, sendo assim do tipo explanatório e descritivo (YIN, 2001; AMADO e FREIRE, 2013).

O pesquisador que escolhe adotar a estratégia de um estudo de caso não está preocupado apenas em generalizar os resultados de seu estudo, mas foca-se também em analisar o caso com profundidade. Além disso, surge o desafio de clarificar o fenômeno e eleger o foco que se pretende estudar e no qual se concentrará a análise 
de dados. Para Amado e Freire (2013), o trabalho com a estratégia do estudo de caso envolve observar e analisar o objeto de forma contextualizada e dinâmica, recorrendo a múltiplas fontes e técnicas com vistas a captar as diferentes óticas dessa complexidade.

Nesse sentido, para definir um caso devemos apresentar um corpo substancial de descrição que seja rico, sendo necessárias diferentes fontes de dados sobre o mesmo objeto. As fontes de dados, assim como os instrumentos e as técnicas de análise de dados, foram escolhidas tendo por base os resultados obtidos em pesquisas anteriores (RABY, 2004; MONTEIRO, 2008; MARQUES, 2008).

Assim, pensamos em uma triangulação de fontes de dados e de técnicas de análise que nos possibilitassem uma maior e melhor exploração e descrição do caso, e também por considerar que é necessário ao investigador a utilização de várias fontes de evidências, de forma a propiciar linhas convergentes de investigação (YIN, 2001). No quadro 1 podemos observar a sistematização das triangulações adotadas, visando responder as questões de estudo já dispostas anteriormente. As descrições dos instrumentos e das técnicas de análise serão discutidas nos itens 3.3 e 3.4, respectivamente. 


\begin{tabular}{|c|c|c|c|c|}
\hline \multicolumn{2}{|c|}{$\begin{array}{l}\text { Questões de } \\
\text { Investigação }\end{array}$} & \multicolumn{2}{|r|}{ Coleta de dados } & \multirow{2}{*}{$\begin{array}{c}\begin{array}{c}\text { Análise de } \\
\text { dados }\end{array} \\
\text { Técnicas }\end{array}$} \\
\hline & & Técnicas & Instrumentos & \\
\hline 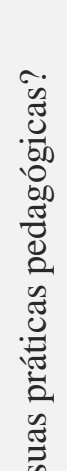 & $\begin{array}{l}\text { Como são } \\
\text { utilizados os } \\
\text { recursos } \\
\text { educacionais } \\
\text { digitais por } \\
\text { professores } \\
\text { nos seus } \\
\text { contextos } \\
\text { profissionais? }\end{array}$ & Questionário & $\begin{array}{l}\text { Questionário on-line: } \\
\text { pt.surveymonkey.com/r/85JR8 } \\
\underline{\text { Y2 }}\end{array}$ & $\begin{array}{l}\text { Análise } \\
\text { estatística } \\
\text { descritiva }\end{array}$ \\
\hline 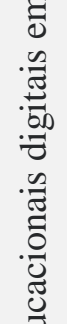 & $\begin{array}{l}\text { O que motiva } \\
\text { os } \\
\text { professores a } \\
\text { usar RED nos } \\
\text { seus } \\
\text { contextos } \\
\text { profissionais? }\end{array}$ & $\begin{array}{l}\text { Questionário } \\
\text { Entrevista }\end{array}$ & Questão aberta & $\begin{array}{l}\text { Análise de } \\
\text { conteúdo }\end{array}$ \\
\hline 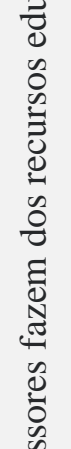 & $\begin{array}{l}\text { Que } \\
\text { correlação } \\
\text { existe entre a } \\
\text { competência } \\
\text { digital dos } \\
\text { professores e } \\
\text { os tipos ou } \\
\text { modos de } \\
\text { utilização de } \\
\text { RED? }\end{array}$ & Questionário & $\begin{array}{l}\text { Questionário on-line: } \\
\text { pt.surveymonkey.com/r/85JR8 } \\
\underline{\text { Y2 }}\end{array}$ & $\begin{array}{l}\text { Análise } \\
\text { estatística } \\
\text { descritiva e } \\
\text { inferencial }\end{array}$ \\
\hline 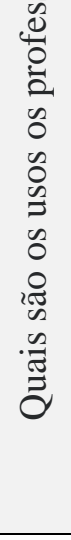 & $\begin{array}{l}\text { Em que } \\
\text { medida o uso } \\
\text { de recursos } \\
\text { educacionais } \\
\text { digitais } \\
\text { contribui } \\
\text { para o } \\
\text { desenvolvime } \\
\text { nto de } \\
\text { práticas } \\
\text { autorais do } \\
\text { professor? }\end{array}$ & Questionário & $\begin{array}{l}\text { Questionário on-line: } \\
\text { pt.surveymonkey.com/r/85JR8 } \\
\underline{\text { Y2 }}\end{array}$ & $\begin{array}{l}\text { Análise } \\
\text { estatística } \\
\text { descritiva e } \\
\text { inferencial }\end{array}$ \\
\hline
\end{tabular}

Quadro 1- Síntese da metodologia empregada. Fonte: Elaboração própria. 


\section{3}

\section{Caracterização dos respondentes ao questionário}

Como já fora abordado, a escolha dos participantes do estudo se deu por meio de uma triagem dos repositórios de RED, tendo a Secretaria Estadual de Educação do Estado do Paraná (SEED-PR) aceitado participar como campo de pesquisa. Chegamos a essa secretaria por meio do Portal Dia a Dia Educação ${ }^{9}$, que dentre outras atribuições, é responsável pelo gerenciamento dos recursos educacionais criados e disponibilizados pelos professores do estado.

O primeiro procedimento para que chegássemos aos participantes da pesquisa foi por meio de um questionário. Solicitamos à equipe pedagógica do Departamento de Políticas e Tecnologias Educacionais (DPTE) que enviasse um questionário on-line, que ficou disponível entre os meses de agosto a novembro de 2018, para os professores que estivessem cadastrados no repositório de recursos educacionais. Como resultado obtivemos a devolutiva de um total de 712 respostas ao instrumento.

Com posse dos questionários respondidos, demos início a segunda estratégia para a seleção dos professores disponíveis a participar das entrevistas. Foi conferida prioridade aos docentes que, a partir de suas respostas, pudéssemos inferir que eram criadores de RED e que desenvolviam práticas de autoria colaborativa de RED com alunos e professores.

A figura 6 demonstra a sistematização dos critérios adotados para elegermos os professores. Podemos atentar que dos 257 professores que concordaram em participar de um segundo momento da pesquisa, apenas 21 docentes se encaixaram na perspectiva de autor de RED. Para nós, esse momento de triagem indicou que que existe um gap entre professores usuários de recursos educacionais e professores autores de recursos. Em uma segunda triagem acrescentamos o fator de criação colaborativa ou professores que constroem práticas de autoria em conjunto com

\footnotetext{
${ }^{9}$ Portal idealizado dentro do projeto Paraná Digital e pensado para que os professores pudessem compartilhar experiências, alimentar o portal com as suas produções e utilizar os conteúdos digitais disponibilizados no repositório (BASNIAK, 2014).
} 
alunos e outros professores para a criação de recursos, configurando 15 participantes.

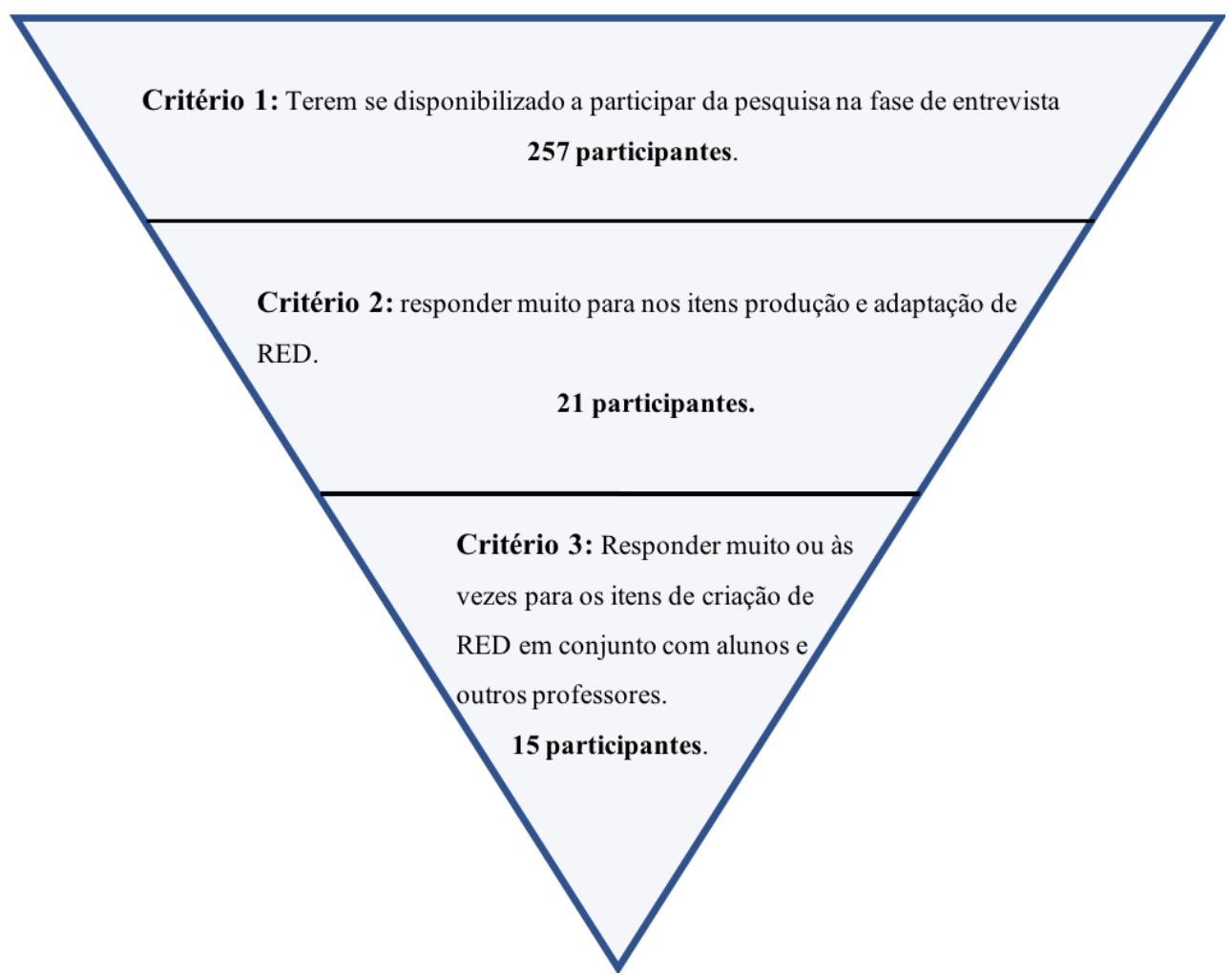

Figura 5 - Critérios adotados para a escolha dos participantes para o grupo focal. Fonte: Elaboração própria.

Seguindo os critérios para a seleção dos professores, conforme demostra a figura 5, foi possível conceber um grupo diversificado de diferentes campos de saber e experiências pedagógicas. Na tabela 2 podemos observar as características dos professores convidados a participarem das entrevistas.

\begin{tabular}{|l|l|l|l|l|}
\hline \multicolumn{1}{|c|}{ Indivíduo } & \multicolumn{1}{|c|}{$\begin{array}{c}\text { Tempo de } \\
\text { Docência }\end{array}$} & $\begin{array}{l}\text { Campo do } \\
\text { Saber }\end{array}$ & \multicolumn{1}{|c|}{ Titulação } & $\begin{array}{l}\text { Segmento } \\
\text { de } \\
\text { Atuação }\end{array}$ \\
\hline Indv. 1 & Mais de dez anos & $\begin{array}{l}\text { Ciências } \\
\text { Humanas }\end{array}$ & Especialização & $\begin{array}{l}\text { Ensino } \\
\text { Médio }\end{array}$ \\
\hline Indiv. 2 & Mais de dez anos & Linguagens & Mestrado & $\begin{array}{l}\text { Ensino } \\
\text { Médio }\end{array}$ \\
\hline Indv. 3 & De três a dez anos & Linguagens & Especialização & $\begin{array}{l}\text { Ensino } \\
\text { Médio }\end{array}$ \\
\hline Indiv. 4 & De três a dez anos & $\begin{array}{l}\text { Ciências } \\
\text { Humanas }\end{array}$ & Especialização & $\begin{array}{l}\text { Ensino } \\
\text { Médio }\end{array}$ \\
\hline
\end{tabular}




\begin{tabular}{|c|c|c|c|c|}
\hline Indiv. 5 & Mais de dez anos & $\begin{array}{l}\text { Ciências } \\
\text { Humanas }\end{array}$ & Especialização & $\begin{array}{l}\text { Ensino } \\
\text { Médio }\end{array}$ \\
\hline Indiv. 6 & Mais de dez anos & $\begin{array}{l}\text { Ciências da } \\
\text { Natureza }\end{array}$ & Especialização & $\begin{array}{l}\text { Ensino } \\
\text { Médio } \\
\end{array}$ \\
\hline Indv. 7 & Mais de dez anos & Linguagens & Especialização & $\begin{array}{l}\text { Ensino } \\
\text { Médio }\end{array}$ \\
\hline Indv. 8 & Mais de dez anos & $\begin{array}{l}\text { Ciências } \\
\text { Humanas }\end{array}$ & Especialização & $\begin{array}{l}\text { Ensino } \\
\text { Médio }\end{array}$ \\
\hline Indiv. 9 & Mais de dez anos & $\begin{array}{l}\text { Áreas } \\
\text { Integradas }\end{array}$ & Especialização & $\begin{array}{l}\text { Ensino } \\
\text { Médio }\end{array}$ \\
\hline Indiv. 10 & Mais de dez anos & $\begin{array}{l}\text { Áreas } \\
\text { Integradas }\end{array}$ & Especialização & $\begin{array}{l}\text { Ensino } \\
\text { Médio }\end{array}$ \\
\hline Indiv. 11 & De três a dez anos & Linguagens & Especialização & $\begin{array}{l}\text { Ensino } \\
\text { Médio }\end{array}$ \\
\hline Indiv. 12 & Mais de dez anos & $\begin{array}{l}\text { Ciências } \\
\text { Humanas }\end{array}$ & Especialização & $\begin{array}{l}\text { Ensino } \\
\text { Médio }\end{array}$ \\
\hline Indiv. 13 & De três a dez anos & $\begin{array}{l}\text { Ciências } \\
\text { Humanas }\end{array}$ & Mestrado & $\begin{array}{l}\text { Ensino } \\
\text { Médio }\end{array}$ \\
\hline Indiv. 14 & Mais de dez anos & $\begin{array}{l}\text { Ciências da } \\
\text { Natureza }\end{array}$ & Doutorado & $\begin{array}{l}\text { Ensino } \\
\text { Médio }\end{array}$ \\
\hline Indiv. 15 & Mais de dez anos & $\begin{array}{l}\text { Ciências } \\
\text { Humanas }\end{array}$ & Doutorado & $\begin{array}{l}\text { Ensino } \\
\text { Médio }\end{array}$ \\
\hline
\end{tabular}

Tabela 2- Docentes participantes do grupo focal. Fonte: Elaboração própria.

De acordo com os dados da tabela 2, verifica-se que quase todos os professores selecionados possuem mais de dez anos de atuação como docentes e contam com pelo menos o grau de especialização. Outra característica é que todos os participantes são docentes do Ensino Médio, podendo ter relação com o fato da Secretaria Estadual de Educação ser responsável pelo segundo segmento do ensino fundamental e médio.

\section{4}

\section{Triangulação e Instrumentos de Pesquisa}

Tendo como norte a importância de considerarmos na pesquisa as relações entre o objeto de estudo e o seu contexto, sua unicidade e a relação observador objeto, optamos por seguir a abordagem da triangulação de fontes de dados e de técnicas de análise. Embora concordemos com Melucci (2005) ao defender que na pesquisa a realidade é sempre artificial, acreditamos que ao combinar diferentes perspectivas de um mesmo objeto o pesquisador pode obter um quadro "mais 
próximo da realidade", sendo o uso de diferentes fontes para um mesmo objeto um tipo de triangulação.

Stake (2005) é assertivo ao explicar que a triangulação possibilita maior precisão dos protocolos nos estudos de caso. Também para Denzin e Lincoln (2006), a triangulação reflete uma tentativa de assegurar uma compreensão profunda de um fenômeno estudado, podendo iluminar a realidade a partir de vários ângulos. Para as autoras:

A triangulação é a exposição simultânea de realidades múltiplas, refratadas. Cada uma metáfora "age" no sentido de criar a simultaneidade, e não o sequencial ou linear. Os leitores e as audiências são então convidados a explorarem visões concorrentes do contexto, a se imergirem e a se fundirem em novas realidades a serem compreendidas. (DENZIN; LINCOL, 2006, p.20)

Outro benefício da triangulação é apontado por Fielding e Schreier (apud DUARTE, 2009) quando afirmam que sua mais-valia não é ajudar o pesquisador a retirar conclusões fidedignas e precisas, mas permitir que o investigador seja mais crítico e cético com relação aos dados coletados. Ressalta-se aqui que a triangulação favorece o controle da qualidade, assim como a garantia da validade do caso a ser estudado. Tais aspectos ficam evidentes quando retomamos o quadro 1, pois percebemos que para responder às questões de estudos propostos precisamos considerar a análise realizada de diferentes fontes de dados, sendo os dados e as técnicas complementares entre si na tarefa de compreender o objeto.

Considerando que a triangulação de fontes é uma das formas de atestar a fiabilidade e a validade na metodologia do estudo de caso (STAKE, 2005), apresentamos os instrumentos escolhidos para essa investigação e seus processos de elaboração. Como verificado na figura 6 , os instrumentos de pesquisa foram compostos por: questionário, questão aberta e entrevistas. 


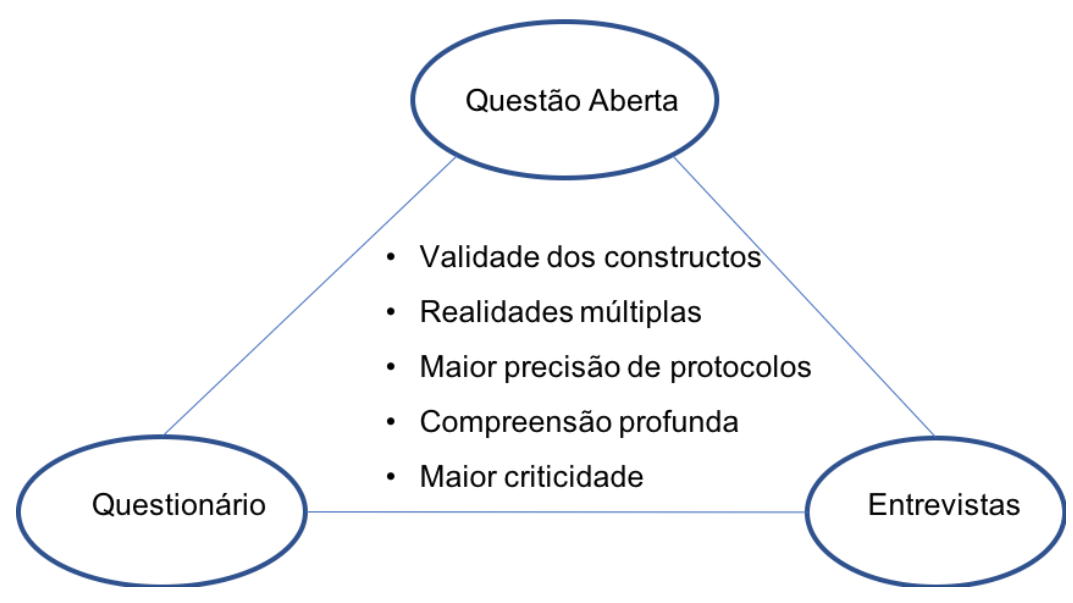

Figura 6 - Triangulação de instrumentos. Fonte: Elaboração própria.

\subsection{1}

\section{Questionário}

O uso do questionário como técnica para coleta e construção de dados em uma pesquisa qualitativa do tipo estudo de caso não é algo consensual entre os autores. Por exemplo, Stake (2005) e Merriam (1998) apresentam como instrumentos de coletas de dados em estudo de caso a análise documental, técnicas de observação e de entrevistas, ou seja, instrumentos utilizados exclusivamente em pesquisas de cunho qualitativo.

Por outro lado, Yin (2001) reconhece a potencialidade de utilizar o questionário como instrumento em estudo de caso, defendendo a possibilidade de utilizar fontes de dados qualitativas e quantitativas ao compor a triangulação de dados. De fato, o estudo de caso pode ser de natureza quantitativa, de natureza fenomenológica e interpretativa, ou mista, conciliando instrumentos e técnicas quantitativas e qualitativas (AMADO; FREIRE, 2013). Para Duarte (2009), a triangulação de fonte de dados supera as dicotomias paradigmáticas que estão por trás dos usos de instrumentos para pesquisas qualitativas e quantitativas, visto que traduz diferentes formas de "olhar a realidade". Nesse sentido, considerando as diferentes perspectivas sobre o uso de dados quantitativos no estudo de caso, assim como as estratégias para a escolha dos participantes explicitado no item 3.2, 
optamos por trabalhar com o questionário de forma a chegarmos nos sujeitos da pesquisa.

Tendo em mente que contávamos com a possibilidade de os participantes do estudo serem residentes de diferentes regiões do país, acreditávamos que o uso do questionário on-line seria o instrumento mais eficiente e econômico para chegarmos a esses sujeitos. De acordo com Gil (2008), entre as vantagens da utilização do questionário estão a possibilidade de atingir um grande número de pessoas, mesmo dispersas geograficamente, permitindo também a resposta ao questionário no momento em que o participante julgar mais conveniente. Acrescenta-se a isso, a possibilidade de quantificar uma variedade de dados e análise de correlação (QUIVY; CAMPENHOUT, 2013).

De acordo com Quivy e Campenhout (2013, p. 188), o “inquérito por questionário de perspectiva sociológica se diferencia de uma sondagem de opinião pelo fato de visar a verificação de hipóteses teóricas e a análise das correlações que essas sugerem". Isso significa que a elaboração de um questionário envolve estudo teórico prévio à sua elaboração, abrangendo múltiplos olhares e atores que participam de sua construção e validação. Compreende também a tradução de objetivos da pesquisa em questões específicas, se convertendo em um procedimento técnico (GIL, 2008).

Nesse sentido, seguindo as orientações da literatura (GIL, 2008; HILL e HILL, 2012; QUIVY e CAMPENHOUT, 2013; PARDAL e LOPES, 2011; TUCKMAN, 2002), apresentamos o processo de concepção e construção do questionário.

\section{Concepção e construção do Questionário}

A elaboração de um questionário não é uma tarefa simples e envolve diferentes etapas. Hill e Hill (2012) alertam para a necessidade de se realizar um estudo preliminar que possa fornecer informações relevantes para a pesquisa, podendo ser estudos que auxiliem a elaboração de um questionário novo ou estudos que permitam testar um questionário que já existe. Fizemos a opção de realizar um estudo preliminar para a construção de um questionário novo, sendo que algumas 
questões foram inspiradas e/ou reelaboradas a partir de questionários utilizados em pesquisas anteriores, e ainda outras foram criadas a partir do estudo da literatura específica.

O quadro 2 evidencia a literatura utilizada para a utilização dos itens e perguntas de questionários anteriores e para a criação de novos itens ou questões. Embora tais pesquisas não tivessem o mesmo objeto e objetivo do estudo atual, muitas questões puderam ser aproveitadas. Outras questões e itens foram criados tendo em vista os objetivos e questões de estudo e a revisão de literatura realizada, procurando determinar e avaliar de forma mais precisa possível o tipo de informação que precisávamos coletar em cada item.

\begin{tabular}{|c|c|}
\hline $\begin{array}{c}\text { Contexto profissional e } \\
\text { Tecnológico }\end{array}$ & $\begin{array}{c}\text { Práticas com os Recursos Educacionais } \\
\text { Digitais }\end{array}$ \\
\hline $\begin{array}{l}\text { CETIC. Pesquisa sobre o uso das } \\
\text { tecnologias de informação e } \\
\text { comunicação nas escolas brasileiras } \\
: \quad \text { TIC Educação } 2016 \text { [livro } \\
\text { eletrônico]. 1. ed. - - São Paulo : } \\
\text { Comitê Gestor da Internetno Brasil, } \\
\text { 2017. }\end{array}$ & $\begin{array}{l}\text { CASTRO, C. A utilização de Recursos } \\
\text { Educativos Digitais no processo de Ensinar e } \\
\text { Aprender: Prática dos Professores e Perspectiva } \\
\text { dos Especialistas. Tese (Doutorado em } \\
\text { Educação). Faculdade de Educação e Psicologia, } \\
\text { Universidade Católica Portuguesa, 2014. }\end{array}$ \\
\hline $\begin{array}{l}\text { PUNIE, Y. (ed). European } \\
\text { Framework for the Digital } \\
\text { Competence of Educators: } \\
\text { DigCompEdu. Publications Office of } \\
\text { the European Union, Luxembourg, } \\
2017 \text {, }\end{array}$ & $\begin{array}{l}\text { LITTLEJOHN, A. et al. Characterising effective } \\
\text { eLearning resources. Computers \& Education, } \\
\mathrm{v} \quad 50, \quad \mathrm{n} .3, \quad 2008 \text {. Disponível em } \\
\text { http://www.sciencedirect.com/science/article/pii/ } \\
\text { S0360131506001254 } \\
\text { LITTEJOHN, A.; HOOD, N. How educators }\end{array}$ \\
\hline $\begin{array}{l}\text { RIEDNER, D. Práticas pedagógicas e } \\
\text { tecnologias digitais no ensino } \\
\text { superior: formação inicial de } \\
\text { professores e inovação na UFMS. } \\
\text { Tese de doutorado em Educação. } \\
\text { Pontifícia Universidade Católica dp } \\
\text { Rio de Janeiro, RJ, 2017. }\end{array}$ & $\begin{array}{l}\text { case of open education resources. British Journal } \\
\text { of Educational Technology, v. 48, n, } 2 \text {, } \\
2017 \text {. } \\
\text { STAGG, A. La adopción de los recursos } \\
\text { educativos abiertos: un continuo de práctica } \\
\text { abierta.Revista del Universidad y Sociedad del } \\
\text { Conocimiento, v. 11. n. 3, } 2014 \text {. }\end{array}$ \\
\hline $\begin{array}{l}\text { CASTRO, C. A utilização de } \\
\text { Recursos Educativos Digitais no } \\
\text { processo de Ensinar e Aprender: } \\
\text { Prática dos Professores e Perspectiva } \\
\text { dos Especialistas. Tese (Doutorado } \\
\text { em Educação). Faculdade de }\end{array}$ & $\begin{array}{l}\text { HADJERROUIT, S. Developing Web-Based } \\
\text { Learning Resources in School Education: A } \\
\text { User-Centered Approach. Interdisciplinary } \\
\text { Journal of Knowledge and Learning Objects, v.6, } \\
2010 .\end{array}$ \\
\hline
\end{tabular}


Educação e Psicologia, Universidade

Católica Portuguesa, 2014.

Quadro 2 - Revisão de literatura para a construção do questionário. Fonte: Elaboração própria.

A construção do questionário foi realizada em duas etapas. Na etapa 1, com base na literatura descrita no quadro 2, começamos a planejar o questionário (HILL e HILL, 2012) pensando nas variáveis da pesquisa e no número de questões ou tamanho do questionário.

Refletindo o objetivo geral e as questões de estudo da pesquisa, dividimos o questionário em três partes, a saber: bloco 1 - perfil dos respondentes; bloco 2 contexto profissional e tecnológico; bloco 3 - recursos educacionais digitais. A primeira versão do questionário foi composta por 23 questões, sendo em sua maioria baseada na escala de Likert, solicitando aos respondentes um grau de concordância (concordo totalmente; concordo; não concordo/nem discordo; discordo/ discordo totalmente) ou de frequência (nunca; raramente; às vezes; quase sempre; sempre) diante das informações. Segundo Pardal e Lopes (2011), as questões do tipo escala de Likert captam os diversos graus de intensidade face a um determinado assunto e possibilitam a concentração do respondente no problema que está sendo estudado.

Para avaliar a primeira versão do questionário foi realizada uma primeira reflexão com os participantes do grupo de pesquisa Formação Docente e Tecnologias (FORTEC), ao qual a pesquisadora está vinculada. Enviamos por email aos integrantes do grupo uma prévia do questionário e solicitamos uma avaliação e/ou reflexão sobre as questões e seus objetivos. Recebemos um total de cinco respostas e a partir das devolutivas vários itens foram reelaborados. Posteriormente o questionário em conjunto com seus objetivos e variáveis foram enviados para a co-orientadora da tese na Universidade de Aveiro. Nessa nova avaliação foram realizadas algumas mudanças em itens que foram julgados repetitivos e na formulação das variáveis que foram julgadas pouco claras.

Posteriormente a essas avaliações e as modificações solicitadas, seguimos para a etapa 2, que configura o pré-teste. Com a realização do pré-teste pretendíamos avaliar a reação dos respondentes ao questionário e corrigir as possíveis falhas remanescentes. De acordo com Pardal e Lopes (2011, p. 85), o pré- 
teste é utilizado "para nos assegurarmos da qualidade das perguntas e da razoabilidade da sua ordenação e para que as respostas tenham possibilidade de corresponder à informação pretendida". Também para Tuckman (2002), a avaliação do pré-teste determina se os itens do questionário possuem qualidade para a medição e descriminabilidade, podendo diagnosticar e corrigir as deficiências do instrumento.

Para selecionar os participantes do pré-teste procuramos um grupo de sujeitos que faziam parte da população intencional do questionário, mas que não fariam parte dos respondentes finais (TUCKMAN, 2002). ${ }^{10}$

O pré-teste foi viabilizado na plataforma SurveyMonkey ${ }^{11}$, que permite disponibilização on-line, gerencia as respostas e exporta os dados em relatório estatístico. O link foi enviado a professores que se identificavam com o tema da educação e tecnologia e que faziam parte da rede de contatos da pesquisadora, que posteriormente enviaram para outros professores em seus ambientes de trabalho e que julgavam serem receptíveis ao tema da educação e tecnologia. O pré-teste foi disponibilizado entre os dias 05 de agosto e 03 de setembro de 2018 e, seguindo essa metodologia, tivemos um retorno de 68 questionários.

Com os resultados do questionário foi realizada uma análise dos resultados em que verificamos as questões e os itens que tiveram o menor índice de respostas pelos professores, considerando que as questões não eram obrigatórias. Assim, as questões que tiverem muitas abstenções foram reformuladas. A partir dos resultados do teste procuramos: avaliar a clareza dos itens; eliminar ambiguidades, dificuldades de interpretação e redundância; e avaliar o tempo de resposta e o tamanho do questionário. Entre as modificações realizadas, reduzimos o quantitativo para 21 questões, suprimimos alguns itens que se repetiam, mas descritos de forma diferente e melhoramos a redação de itens que foram apontados pelos professores como ambíguos ou de difícil interpretação. Também reduzimos

\footnotetext{
${ }^{10}$ Entramos em contato com algumas secretarias municipais de educação no estado do Rio de Janeiro solicitando o envio do pré-teste para os professores, mas não obtivemos resposta. Em uma segunda abordagem mapeamos grupos de professores pelo Facebook com a temática educação e tecnologias e pedimos para que os professores respondessem ao pré-teste mas tivemos um número muito pequeno de respostas. Por fim, foi utilizada rede de contato da pesquisadora.

${ }^{11}$ Disponível em https://pt.surveymonkey.com
} 
as opções da escala de Likert visando o maior engajamento dos respondentes e a diminuição do tempo gasto, aumentando a probabilidade dos sujeitos finalizarem o questionário.

O questionário final ficou estruturado da seguinte forma:

i) Apresentação do questionário e o termo de consentimento livre e esclarecido.

ii) Bloco Perfil dos Respondentes, composto por 11 questões com o objetivo de caracterizar o perfil profissional, social e econômico.

iii) Bloco Contexto Profissional e Tecnológico, com 5 questões e 28 itens com o objetivo de caracterizar o contexto tecnológico do professor e seu nível de letramento digital.

iv) Bloco Práticas com os Recursos Educacionais Digitais, composto por 4 questões fechadas com 36 itens e 1questão aberta.

v) Finalização do questionário perguntando a disponibilidade dos respondentes em participar de grupo focal ou entrevista individual.

O quadro 3 nos permite depreender, de forma mais detalhada, como ficou organizado o questionário final, considerando cada bloco, seus objetivos e suas variáveis.

\begin{tabular}{|c|c|c|c|}
\hline Objetivo & $\begin{array}{l}\text { Dimensões e Objetivos } \\
\text { Específicos }\end{array}$ & Variáveis & Quest. \\
\hline $\begin{array}{l}\text { Caracterizar } \\
\text { o perfil } \\
\text { profissional } \\
\text { dos } \\
\text { professores. }\end{array}$ & $\begin{array}{l}\text { Bloco 1: Perfil dos } \\
\text { Respondentes. } \\
\text { - Caracterizar o perfil } \\
\text { profissional, social e } \\
\text { econômico dos } \\
\text { professores. } \\
\text { - Caracterizar o tipo de } \\
\text { formação recebida e a } \\
\text { forma de atuação na } \\
\text { educação. }\end{array}$ & $\begin{array}{l}\text { Gênero. } \\
\text { Nível Sócio-econômico. } \\
\text { Idade. } \\
\text { Região Administrativa. } \\
\text { Tempo de Docência. } \\
\text { Tipos de escolas em que atua. } \\
\text { Segmento da Educação em que atua. } \\
\text { Área do conhecimento em que } \\
\text { leciona. } \\
\text { Maior nível de formação. } \\
\text { Formação continuada em educação } \\
\text { e tecnologia. } \\
\text { Formas de acesso ao curso. }\end{array}$ & $\begin{array}{l}\text { Q1 } \\
\text { Q2 } \\
\text { Q3 } \\
\text { Q4 } \\
\text { Q5 } \\
\text { Q6 } \\
\text { Q7 } \\
\text { Q8 } \\
\text { Q9 } \\
\text { Q10 } \\
\text { Q11 }\end{array}$ \\
\hline $\begin{array}{l}\text { Caracterizar } \\
0 \quad \text { contexto }\end{array}$ & $\begin{array}{lr}\text { Bloco 2: } & \text { Contexto } \\
\text { profissional } & \mathrm{e}\end{array}$ & & \\
\hline
\end{tabular}




\begin{tabular}{|c|c|c|c|}
\hline $\begin{array}{l}\text { Identificar a } \\
\text { correlação } \\
\text { entre o nível } \\
\text { de } \\
\text { letramento } \\
\text { do professor } \\
\text { e os tipos ou } \\
\text { modos de } \\
\text { usos dos } \\
\text { recursos } \\
\text { educacionai } \\
\text { s. }\end{array}$ & 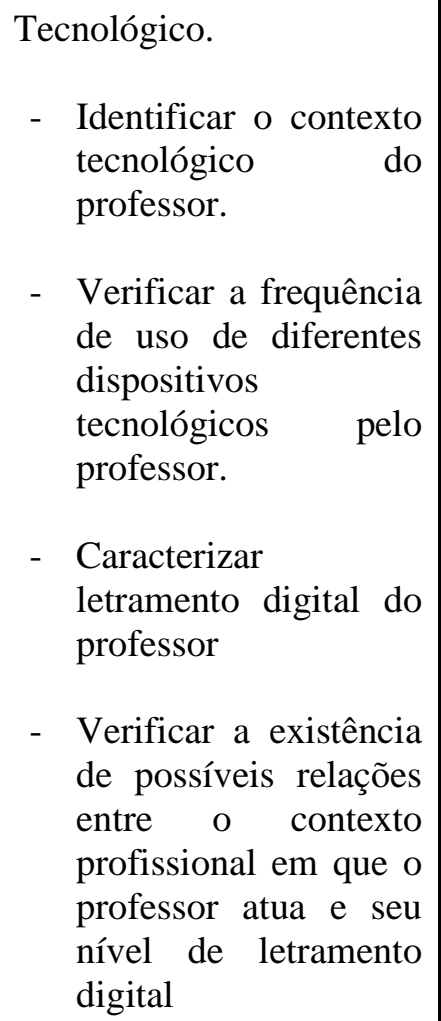 & $\begin{array}{l}\text { Tecnologias que estão acessíveis e } \\
\text { funcionantes nas instituições em que } \\
\text { os professores atuam. } \\
\text { Frequência com que os professores } \\
\text { utilizam diferentes tecnologias em } \\
\text { seu cotidiano. } \\
\text { Habilidades que envolvem prática } \\
\text { pedagógica e o uso da tecnologia. } \\
\text { Possíveis relações que a instituição } \\
\text { do professor tem com a tecnologia. } \\
\text { Atuação do professor em seu } \\
\text { contexto profissional com respeito } \\
\text { ao compartilhamento de atividades } \\
\text { pedagógicas em uma comunidade } \\
\text { de prática }\end{array}$ & $\begin{array}{l}\text { Q14 } \\
\text { Q15 }\end{array}$ \\
\hline $\begin{array}{l}\text { Caracterizar } \\
\text { as práticas, } \\
\text { autoria e } \\
\text { compartilha } \\
\text { mento de } \\
\text { recursos } \\
\text { educacionai } \\
\text { s pelos } \\
\text { professores. }\end{array}$ & $\begin{array}{l}\text { Bloco 3: Práticas com os } \\
\text { Recursos Educacionais } \\
\text { Digitais. } \\
\text { - Especificar os tipos de } \\
\text { recursos educacionais } \\
\text { digitais utilizados } \\
\text { pelos professores e } \\
\text { suas práticas. } \\
\text { - Detectar a atitude do } \\
\text { professor com relação } \\
\text { aos RED. } \\
\text { - Identificar a } \\
\text { motivação dos } \\
\text { professores para o uso } \\
\text { de RED. }\end{array}$ & $\begin{array}{l}\text { Tipologia dos recursos educacionais } \\
\text { digitais (RED) mais utilizados pelos } \\
\text { professores. } \\
\text { Práticas pedagógicas com os RED } \\
\text { que professores realizam em seus } \\
\text { contextos profissionais. } \\
\text { Possíveis relações entre os sujeitos, } \\
\text { RED e contextos sociais. } \\
\text { Possíveis práticas de autoria que os } \\
\text { professores realizam com os RED. } \\
\text { Motivação do professor para as } \\
\text { práticas educacionais com os RED. }\end{array}$ & $\begin{array}{l}\text { Q17 } \\
\text { Q18 }\end{array}$ \\
\hline
\end{tabular}

Quadro 3 - Síntese do questionário. Fonte: Elaboração própria 


\subsection{2.}

\section{Entrevistas}

Ressaltamos que a primeira opção ao idealizarmos o desenho metodológico da pesquisa foi a utilização da técnica do grupo focal, por ser uma técnica amplamente utilizada e consolidada nas pesquisas qualitativas. De acordo com Bryman (2012), o grupo focal é um método para entrevistar ao menos quatro pessoas, buscando dar ênfase em um tópico ou tema específico que precisa ser explorado em profundidade e o interesse ou foco nas interações que os participantes criam entre si e no modo em que discutem e respondem uns aos outros.

Entendíamos que a opção por esta técnica estava relacionada com a expectativa dos dados mais significativos das falas dos sujeitos serem provenientes das interações, insights e conflitos que poderiam surgir no decorrer de cada sessão. Ou seja, são os dados produzidos a partir das divergências e/ou convergência de ideias.

Considerando que os participantes do grupo focal estariam dispersos em diferentes regiões do estado do Paraná, achamos viável a realização do grupo focal on-line. Bryman (2012) explica que o avanço e a ampla utilização da internet de banda larga têm influenciado a forma em que pesquisadores estão coletando dados, como o envio de questionários on-line, etnografia on-line, observação no ciberespaço, entrevistas individuais e no nosso caso, grupos focais on-line (GFO).

No item 3.3 abordamos as estratégias adotadas para a escolha dos participantes convidados para o GFO. Assim, todos os participantes tinham diferentes graus de experiências com ferramentas tecnológicas, utilizavam as tecnologias e os recursos educacionais digitais em suas práticas pedagógicas e realizavam processos e práticas autorais com esses recursos sozinhos e com os seus pares. Considerando que 15 professores se adequaram no perfil traçado e seguindo as orientações sobre a importância de se trabalhar em grupos menores, especialmente com grupos on-line (ABREU, BALDANZA e GONDIN, 2009; GATTI, 2012; BRYMAN, 2012), optamos por convidar os professores para formarem três grupos focais de cinco pessoas. 
Contudo, o que se verificou na prática foi uma grande dificuldade de disponibidade ou de interesse dos professores na participação no segundo momento da pesquisa. Acreditamos que questões como excesso de trabalho, falta de tempo e desistência foram os principais motivos para a não participação dos professores da entrevista desta etapa da pesquisa. Cabe ressaltar, que o convite para a participação nos GFO se deu no início do segundo semestre de 2019, período em que muitos professores estão debruçados com o planejamento do semestre e com a volta das férias escolares.

Foram enviados emails para os 15 professores selecionados para o GFO e 8 docentes responderam ao email, concordando com o termo de consentimento livre e esclarecido. Ao propormos o GFO não houve aderência dos participantes, especialmente pela dificuldade em se estabelecer horários compatíveis com outras pessoas. Nesse sentido, diante da dificuldade da realização do GFO, foi cogitado junto aos participantes a realização de entrevistas individuais on-line.

Segundo Quivy e Campenhoudt (1998, p.193), a entrevista é um método apropriado para a

análise do sentido que os atores dão às suas práticas e aos acontecimentos com os quais se veem confrontados: os seus sistemas de valores, as suas referências normativas, as suas interpretações de situações conflituosas ou não, as leituras que fazem das suas próprias experiências, etc

Ainda para Gaskell (2003), o uso da entrevista possibilita ao pesquisador utilizar esquemas interpretativos para compreender as narrativas dos atores, visto que fornece dados para o entendimento das relações entres os atores sociais e seu contexto social específico. Dentre os tipos de entrevistas, adotamos a entrevista semiestruturada. Segundo Amado e Ferreira (2013), este tipo de abordagem não impõe questões rígidas, permitindo ao entrevistado discorrer sobre o tema proposto, podendo dar ênfase ao que é mais relevante, segundo o seu julgamento. Nesta abordagem, as questões das entrevistas derivam de um plano prévio ou guia em que se define aquilo que é essencial obter durante a entrevista, embora o entrevistado tenha grande liberdade durante sua resposta. 
Diante da dificuldade da realização de GFO, tomamos um segundo caminho por realizar entrevistas individuais on-line, também por acreditar que esta técnica, assim como apontado por Quivy e Campenhoudt, permitiria ao investigador conhecer os sentidos que os sujeitos dão às suas práticas.

A interface tecnológica utilizada para as entrevistas foi a chamada de vídeo do Whatsapp, por ter sido a preferência dos entrevistados, visto que nossa primeira opção foi a utilização da plataforma de videoconferência Whereby®. De acordo com Bryman (2012), assim como o GFO, a entrevista qualitativa on-line também é considerada uma técnica de pesquisa baseada na internet, tendo vantagens no uso quando o entrevistador e o entrevistado estão em diferentes espaços, sendo inviável ou muito custosa a realização desta técnica presencialmente.

\subsubsection{1}

\section{Concepção do roteiro}

Ressaltamos que o processo de construção até chegarmos ao roteiro da entrevista passou por várias etapas de desenvolvimento, especialmente pela necessidade de mudarmos, durante o decorrer da pesquisa, a técnica do GFO para a entrevista individual on-line.

Em um primeiro momento, na elaboração do roteiro para o grupo focal, seguimos algumas das recomendações da literatura, particularmente as sugestões de Bryman (2012) e Gatti (2012) e o estudo de Martins (2009), que utilizou os grupos focais como fonte para a coleta de dados. Posteriormente, foi necessário voltarmos para as questões de estudo que seriam respondidas a partir dos dados do grupo focal, para a revisão de literatura já realizada e para os dados resultantes do questionário com questões abertas e fechadas.

A partir dessa releitura organizamos a estrutura do grupo focal, em que listamos um conjunto de perguntas que correspondiam às questões de estudo e aos pontos dos dados oriundos do questionário que precisavam ser aprofundados. Refletimos no objetivo de cada questão formulada, sua contribuição para o estudo, e os tópicos que cada questão precisaria contemplar.

Como processo de validação do roteiro do grupo focal, adotou-se uma rodada de reflexão junto a co-orientadora da tese da versão 1. A partir das reflexões 
e considerando as modificações sugeridas elaborou-se uma segunda versão do roteiro que foi submetida para avaliação de juízes durante o exame de qualificação II da pesquisadora.

Esta última validação levou a fazer as seguintes alterações: i) redução do número de questões; ii) modificação de enunciados de questões por recomendação dos juízes, por serem considerados ambíguos ou por dificuldade no entendimento; iii) inclusão de figuras para atividade inicial do GFO; iv) diminuição dos itens do bloco A e D para que o tempo do grupo focal fosse dedicado às questões mais significativas.

Considerando a inviabilidade da realização do GFO, foi feita uma entrevista piloto com o roteiro elaborado, originando uma nova validação. No anexo VII verifica-se a versão final adotada na entrevista semiestruturada e as mudanças ocorridas.

\section{5}

\section{Procedimentos para Análise de Dados}

Seguindo a lógica da triangulação das fontes de dados e instrumentos, a metodologia adotada nessa pesquisa foi composta por análise estatística descritiva e inferencial e a análise de conteúdo da questão aberta do questionário e das entrevistas.

\subsection{1}

Análise Estatística Descritiva e Inferencial

O questionário desenvolvido na plataforma Survey Monkey nos permitiu extrair os dados organizados com as variáveis e respostas em diferentes formatos de planilhas para uso nos programas Excel e SPSS ${ }^{12}$. Tivemos o retorno de 712 questionários, sendo que, pela resposta a cada item não ser obrigatória, analisamos apenas os casos válidos de cada questão, descartando os dados omissos.

\footnotetext{
${ }^{12}$ Statistical Package for the Social Sciences - pacote estatístico para as ciências sociais
} 
Os dados das questões fechadas extraídas do questionário foram analisados por meio de procedimentos estatísticos descritivos e inferenciais. A estatística descritiva é utilizada para descrever características de uma ou mais variáveis, resumindo e organizando as informações relevantes. Com essa primeira análise é possível ao investigador identificar se os dados seguem algum modelo que permita o estudo de um dado fenômeno (OLIVEIRA, 2007).

As questões do número 03 ao número 15 visam a caracterização dos participantes da pesquisa e apresentam análise de cunho exploratório. Os dados organizados foram apresentados em forma de tabelas e gráficos de forma a facilitar a compreensão de suas principais características.

Nas questões do número 16 ao número 21 foram realizadas análise estatística inferencial, utilizando o cálculo do coeficiente de correlação de Pearson (LEVIN; FOX, 2004). Esse tipo de análise é utilizado quando precisamos comparar dois ou mais grupos de variáveis independentes e/ou dependentes. Em nosso caso, o cálculo de correlação de Pearson foi pensado para investigar se seria possível estabelecermos algum tipo de relação nos seguintes casos:

1. Se as práticas de autoria de recursos educacionais digitais se relacionam com: i) uso pessoal das TIC; ii) uso das TIC na prática pedagógica; iii) atitude relativa com os RED; iii) contexto tecnológico.

2. Se as práticas de compartilhamento de RED se relacionam com: i) uso pessoal das TIC; ii) uso das TIC na prática pedagógica; iii) atitude relativa com os RED; iv) contexto tecnológico.

Para a realização da análise estatística inferencial seguimos os procedimentos: 1) criação dos constructos por agrupamento dos indicadores; 2) recodificação e cálculo das médias dos indicadores por cada respondente; 3) cálculo do coeficiente de correlação e análise.

A partir da revisão de literatura, dos objetivos e questões de investigação foram criados sete construtos para a realização do cálculo de correlação. Sendo os construtos de variáveis independentes: 1) uso pessoal das TIC; 2) uso das TIC na prática pedagógica; 3) uso das TIC na gestão pedagógica; 4) atitude relativa aos recursos educacionais digitais; 5) contexto tecnológico. Já os construtos de 
variáveis dependentes utilizados foram: A) práticas de autoria de recursos educacionais digitais e B) práticas de compartilhamento de recursos educacionais digitais.

De forma a ilustrarmos como se deu a elaboração de cada um dos construtos, trazemos o exemplo da variável dependente "práticas de autoria de recursos educacionais digitais". Para a formação desse construto utilizamos os seguintes indicadores pertencentes ao questionário: a) produzo RED para serem usados em sala de aula; b) realizo adaptações de RED encontrados em repositórios; c) crio RED em conjunto com os alunos d) elaboro RED a partir da combinação com outros recursos; e) produzo estratégias de aprendizagem com RED; f) desenvolvo RED em parceria com outros professores; g) compartilho RED de minha autoria, enviando-os para repositórios; h) reuso um mesmo RED em diferentes contextos pedagógicos.

Após a formação dos construtos seguimos para a recodificação das respostas de cada inquirido. Nesse sentido, recodificamos as respostas seguindo o padrão: respostas nominais de "pouco" ou "não concordo" foram substituídas pelo numeral 1; respostas nominais de "às vezes" ou "não concordo/ nem discordo" foram substituídas pelo numeral 2; respostas nominais de "muito" ou "concordo" foram substituídas pelo numeral 3. A tabela 3 demonstra o processo na formação do construto.

Formação do construto: “práticas de autoria de RED”

\begin{tabular}{|l|l|l|l|l|l|l|}
\hline & $\begin{array}{c}\text { Indicador } \\
\mathrm{a}\end{array}$ & $\begin{array}{c}\text { Indicador } \\
\mathrm{b}\end{array}$ & $\begin{array}{c}\text { Indicador } \\
\mathrm{c}\end{array}$ & $\begin{array}{c}\text { Indicador } \\
\mathrm{d}\end{array}$ & $\begin{array}{c}\text { Indicador } \\
\mathrm{F}\end{array}$ & Média \\
\hline Indv. 1 & 1 & 2 & 2 & 2 & 3 & 2,125 \\
\hline Indv. 2 & 3 & 3 & 1 & 3 & 3 & 2,375 \\
\hline Indv. 3 & 1 & 1 & 1 & 1 & 1 & 1 \\
\hline Indv. 5 & 1 & 2 & 1 & 2 & 1 & 1,25 \\
\hline
\end{tabular}

Tabela 3 - Exemplo de formação de construto. Fonte: Elaboração própria.

A tabela acima nos permite visualizar os procedimentos para a elaboração do construto. Nesse sentido, observamos que a média dos indicadores origina os 
dados do construto, sendo posteriormente utilizada para o cálculo de coeficiente de correlação ${ }^{13}$. Após a criação de cada construto, seguido das médias de cada respondente, foram realizados os cálculos do coeficiente de correlação de Pearson, seguindo as questões de investigação para a análise de correlação.

Levin e Fox (2004) explicam que o coeficiente de correlação é o grau de associação que pode existir entre duas variáveis, considerando o grau de intensidade linear nessa variação. A associação das variáveis ocorre quando existem semelhanças na distribuição dos seus scores, podendo ser distribuídas pelo compartilhamento de variância. De acordo com Figueiredo Filho e Silva Junior (2009, p. 119), esse último parâmetro é o caso da correlação de Pearson, ou seja, "exige compartilhamento de variância e que essa variação seja distribuída linearmente".

Os resultados do cálculo de coeficiente podem variar entre -1 e 1 . A negatividade ou a positividade indica a direção do relacionamento das variáveis e o valor sugere a força da relação, assim quanto mais próximo de -1 ou 1 , maior o grau de associação entre variáveis (FIGUEIREDO FILHO e SILVA JUNIOR, 2009). Para a interpretação dos valores do coeficiente nos baseamos nos intervalos propostos por Reis (1997). O autor explica que por convenção, considera-se que o coeficiente menor que 0,2 indica uma relação muito baixa; entre 0,2 e 0,39 baixa; entre 0,4 e 0,69 moderada; entre 0,7 e 0,89 alta; entre 0,9 e 1 uma associação muito alta. Os resultados do cálculo do coeficiente poderão ser acompanhados no capítulo 4 , referente à descrição dos dados.

\section{5 .2}

\section{Análise de Conteúdo}

Os procedimentos da análise de conteúdo (AC) foram utilizados nesse estudo em dois momentos distintos: i) a análise da questão aberta do questionário e ii) a análise das entrevistas.

\footnotetext{
13 No anexo IV estão descritos os indicadores utilizados para a composição de cada um dos construtos das variáveis dependentes e independentes.
} 
Segundo Amado et al. (2013, p. 300), a utilidade dessa técnica se fundamenta pela "possibilidade de fazer inferências interpretativas a partir dos conteúdos expressos, uma vez desmembrados em 'categorias', tendo em conta as 'condições de produção' desses mesmos conteúdos, com vistas à explicação e compressão dos mesmos". A análise de conteúdo também se justifica pela função e importância do pesquisador ao fazer uma análise interpretativa de uma realidade social, considerando suas 'condições de produção' ou contexto.

Os entendimentos dos autores convergem para a conceituação de Bardin (1977) quando esta afirma que os métodos da análise de conteúdo correspondem à ultrapassagem da incerteza, por garantir maior rigor metodológico e ao enriquecimento da leitura, de forma a melhorar a produtividade e a pertinência do conteúdo para além de uma simples leitura, tendo a inferência um papel central nesse processo. Nesse sentido, a análise de conteúdo viabiliza ao pesquisador a leitura das "entrelinhas" do texto desvelando significados ocultos a uma leitura comum.

De acordo com a autora, "a intenção da análise de conteúdo é a inferência de conhecimentos relativos às condições de produção (ou, eventualmente, de recepção), inferência esta que recorre a indicadores (quantitativos ou não)" (BARDIN, 1977, p. 38). Nas palavras da autora:

Tal como a etnografia necessita da etnologia, para interpretar as suas descrições minuciosas, o analista tira partido do tratamento das mensagens que manipula, para inferir (deduzir de maneira lógica) conhecimentos sobre o emissor da mensagem ou sobre o seu meio, por exemplo. Tal como um detetive, o analista trabalha com indices cuidadosamente postos em evidência por procedimentos mais ou menos complexos. Se a descrição (a enumeração das características do texto, resumida após tratamento) é a primeira etapa necessária e se a interpretação (a significação concedida a estas características) é a última fase, a inferência é o procedimento intermediário, que vem permitir a passagem, explícita e controlada, de uma a outra (BARDIN, 1977, p. 39). 
Para que o pesquisador consiga fazer esse trabalho de descrição, inferência e interpretação da mensagem é preciso assimilar a análise de conteúdo como técnica (objetividade, fidelidade, validade) e enquanto método (operacionalização das variáveis, validade externa, generalização) (AMADO et al., 2013; BAUER, 2008) podendo utilizar softwares de apoio com o intuito de dar maior rigor aos aspectos técnicos e metodológicos.

Entre os benefícios de se utilizar os softwares de análise qualitativa estão a maior eficiência na gestão de dados e ideias; modelação gráfica e análise de um maior volume de dados; redução da complexidade do processo de análise e maior rigor metodológico; consistência e transparência analítica (COSTA; AMADO, 2018). Acrescentam-se a essas vantagens a inclusão de procedimentos de contextualização e validação, a definição de categorias de forma indutiva e dedutiva, codificação e recodificação, exploração e cruzamento de diferentes formatos de dados. (COSTA; REIS, 2017).

Existem diversas opções de softwares de apoio para a pesquisa qualitativa e, no caso dessa investigação, optamos pelo WebQDA. Segundo Costa e Amado (2018), esse software é direcionado para pesquisadores de abordagem qualitativa, permitindo por um lado editar, visualizar, interligar e organizar documentos, e por outro lado, criar categorias, codificar, controlar, filtrar, procurar e questionar os dados segundo objetivos de pesquisa pré-determinados. Comparados a outros softwares de análise qualitativa, o WebQDA apresenta as vantagens de ser baseado na web e permitir um trabalho de análise colaborativa e simultânea com vários pesquisadores de um mesmo projeto. A seguir descreveremos as etapas de análise desenvolvidas com o apoio do software WebQDA.

\subsubsection{1}

Procedimentos adotados na análise de conteúdo

O desenho praticado como procedimentos para a análise de conteúdo teve por base as orientações de Bardin (1977) e Amado et al. (2013). O processo de análise dos dados, que será descrito a seguir, foi estruturado em: (i) organização 
dos dados e pré-análise; (ii) codificação e categorização; (iii) inferência e interpretação.

\section{Organização dos dados e pré-análise}

A fase da preparação dos dados para análise de conteúdo é constituída pela seleção do material a ser analisado, o delineamento dos objetivos e/ou hipóteses da análise e a construção de uma ideia prévia de categorização.

O primeiro movimento para a organização foi revisitar os objetivos do trabalho para condicionar as decisões no processo de codificação dos dados. Posteriormente nos voltamos ao quadro do referencial teórico que nos permitiu questionar os dados e avançar em explicações e interpretações dos mesmos (AMADO et al., 2013).

Por fim, foi constituído o corpus de análise para a pesquisa e sua decorrente leitura, que em nosso caso foi formada pela questão aberta do questionário e as transcrições das entrevistas, sendo analisados separadamente. Realizamos uma leitura flutuante (BARDIN, 1977) para uma primeira familiarização com o corpus, tendo em mente as categorias construídas para análise e sendo sensível para a emergência de outras categorias ou subcategorias.

\section{Codificação e Categorização com o apoio do WebQDA}

A codificação corresponde ao processo de tratamento dos dados brutos, ocorrendo por meio de recorte, agregação e enumeração que permite ao pesquisador alcançar a representação do conteúdo (BARDIN, 1977). Seguindo Amado et al. (2013), antes de começarmos os procedimentos de codificação e categorização é preciso escolher o tipo de procedimento que será feito, a saber: fechado, aberto ou misto. Por um lado, a revisão de literatura realizada previamente contribuiu para a criação de algumas categorias prévias, levando-nos a fazer uma análise dedutiva dos conteúdos. Por outro lado, adotamos em conjunto uma análise indutiva aberta ao surgimento de outras categorias e subcategorias a partir da análise de conteúdo, perfazendo assim, uma abordagem de análise mista. 
Seguindo esse tipo de abordagem criamos um sistema de codificação a partir dos objetivos e questões de estudo da pesquisa, da leitura do referencial teórico e da "leitura flutuante" do corpus. O quadro 5 mostra as categorias e subcategorias adotadas no processo de inferência e interpretação da questão aberta.

\begin{tabular}{|c|l|}
\hline Categorias & Subcategorias \\
\hline \multicolumn{1}{|c|}{ Ensino/Aprendizagem } & Processo e resultados da aprendizagem \\
\cline { 2 - 2 } & $\begin{array}{l}\text { Suporte ao conteúdo (centrado na aprendizagem de } \\
\text { conteúdos }\end{array}$ \\
\hline $\begin{array}{c}\text { Desenvolvimento profissional } \\
\text { docente }\end{array}$ & Alteração/inovação de práticas de ensino \\
\cline { 2 - 2 } & $\begin{array}{l}\text { Desenvolvimento de competências pedagógicas } \\
\text { digitais }\end{array}$ \\
\hline Praticante da cultura digital & Professor inserido na cultura digital \\
\cline { 2 - 2 } & Escola inserida na cultura digital \\
\cline { 2 - 2 } & Aluno inserido na cultura digital \\
\hline Quadro 4 - Sistema de Categorias da questão aberta. Fonte: Elaboração Própria. \\
\hline
\end{tabular}

Para a construção do sistema de categorias, seguindo a abordagem mista (AMADO et al., 2013), realizamos a leitura flutuante dos dados em conjunto com a revisão bibliográfica feita anteriormente e a retomada dos objetivos e questões de estudo, elegendo as categorias mais evidentes a partir das leituras e discussões. Para assegurarmos a validade interna do sistema de categorias é preciso considerarmos a exaustividade - alcance de todos os itens relevantes para o estudo; exclusividade - a unidade de registro deve pertencer apenas a uma categoria; homogeneidade - o sistema de categoria deve se referir a apenas um único tipo de análise; pertinência - sistema de categorias deve ser adaptado ao corpus de análise; objetividade - evitar a subjetividade e ambiguidade; produtividade - possibilitar análises que permitam a elaboração de novos construtos congruente com o corpus (AMADO, 2013).

Após a criação da categorização seguimos para a fidelização do sistema criado. De acordo com Amado (2013), é importante que a análise seja fiel aos conteúdos e que as categorias criadas pelo analista traduzam o sentido dos dados. $\mathrm{O}$ autor explica que 
No que respeita à fiabilidade do processo procura-se ter a certeza de que as categorias foram definidas de um modo tão operacional que outro analista [...] utilizando essas mesmas definições, faria uma categorização/análise muito semelhante à primeira (p.337).

Nesse sentido, para garantir a fiabilidade do sistema de categorias seguimos as orientações de Amado e solicitamos aos pesquisadores especialistas no tema deste estudo que analisassem a categorização de uma amostra aleatória simples do corpus de dados. Posteriormente, comparamos as codificações dos juízes com a realizada pelo investigador e seguiu-se um cálculo, considerando os acordos e desacordos e utilizando uma fórmula em que a soma do número de acordo (Ta) deve ser dividida pela soma do total do número de acordos (Ta) com o total do número de desacordo (Td). De acordo com Amado et al. (2013), se o resultado for próximo a 0.80 indica um sistema de categorias satisfatório.

Seguindo estes procedimentos verificamos a seguinte composição de acordo e desacordos entre os avaliadores:

- Avaliador 1:

Ta: 28/ Td: 7

- Avaliador 2

Ta: 31/ Td: 4

Para análise de fiabilidade do processo, Amado et al. (2013) recomenda que a comparação das codificações de dois avaliadores externos com a realizada pelo pesquisador. Considerando que a codificação do avaliador 3 foi invalidada por não ter seguido as orientações de análise para a validação das categorias, foram utilizadas as codificações dos avaliadores 1 e 2 . Seguindo a fórmula apresentada pelo autor obtivemos o seguinte resultado:

Fórmula:

$$
F=\frac{T a}{T a+t d}
$$

Onde:

$$
F=\frac{28+31}{(28+31)+(7+4)}=0.84
$$


De acordo com Amado um resultado próximo de 0.8 indica um sistema de categoria satisfatório.

Para a análise das entrevistas, considerando que o roteiro se direciona mais para as práticas autorais dos professores com os RED, optou-se pelo uso do procedimento aberto ao invés de partir de um sistema de categorias préestabelecido. Esse procedimento é conhecido como Grounded Theory ou Teoria Fundamentada em Dados (GLASER e STRAUSS, 1967) e aborda um modo de se construir uma teoria baseada no dados, assim, o pesquisador, combinando abordagens indutivas e dedutivas, constrói construtos teóricos que explicam os dados provenientes de um determinado fenômeno social, trazendo novos conhecimentos ao campo ciêntifico em que se insere a pesquisa.

Ao ser abordado na análise de conteúdo, este procedimento possibilita a construção de um sistema de categorias puramente induzido a partir da análise, mesmo que ainda subordinado ao background teórico do investigador (AMADO, 2013). Neste caso, “a interpretação exigida para uma categorização válida será tanto mais penetrante quanto mais o intérprete estiver teoricamente apetrechado para interrogar os dados" (p. 316). Nesse sentido, o referencial teórico tem importância indispensável para a construção de um sistema de categorias, seja no modelo misto ou aberto.

No decurso da análise das entrevistas foi construído o seguinte sistema de categorias:

Categorias

Subcategorias

\begin{tabular}{l|l|}
\hline Concepções sobre Autoria & Definições de autoria \\
\cline { 2 - 2 } & Práticas autorais na docência \\
\cline { 2 - 2 } & Influência da Autoria docente \\
\hline \multicolumn{2}{|l}{ Percurso para a autoria docente } \\
\hline Relações da autoria docente & Uso de RED e outras tecnologias \\
\hline com a tecnologia & Criação de RED \\
\hline & Competências digitais \\
\hline
\end{tabular}

Quadro 5 - Sistema de Categorias das entrevistas. Fonte: Elaboração Própria. 


\section{Inferência e interpretação da análise.}

A interpretação do sentido do texto depende de um longo processo de releituras intensivas das unidades de registro, das categorias e subcategorias construídas pelo analista. De acordo com Amado (2013), a fase interpretativa deve se apoiar em todo o trabalho desenvolvido anteriormente, isso permitirá ao analista levar em conta todos os tipos de relações que estabelecem os diferentes temas. O autor chama a atenção para o desafio do analista de conteúdo se manter fiel aos sistemas de categorias pré-estabelecidos e não se deixar influenciar por sua posição pessoal no processo interpretativo. Nesse aspecto, contar com o apoio do software WebQDA fortalece a confiabilidade da análise e sua interpretação.

$\mathrm{Na}$ figura 7 podemos visualizar os procedimentos realizados na análise de conteúdo.

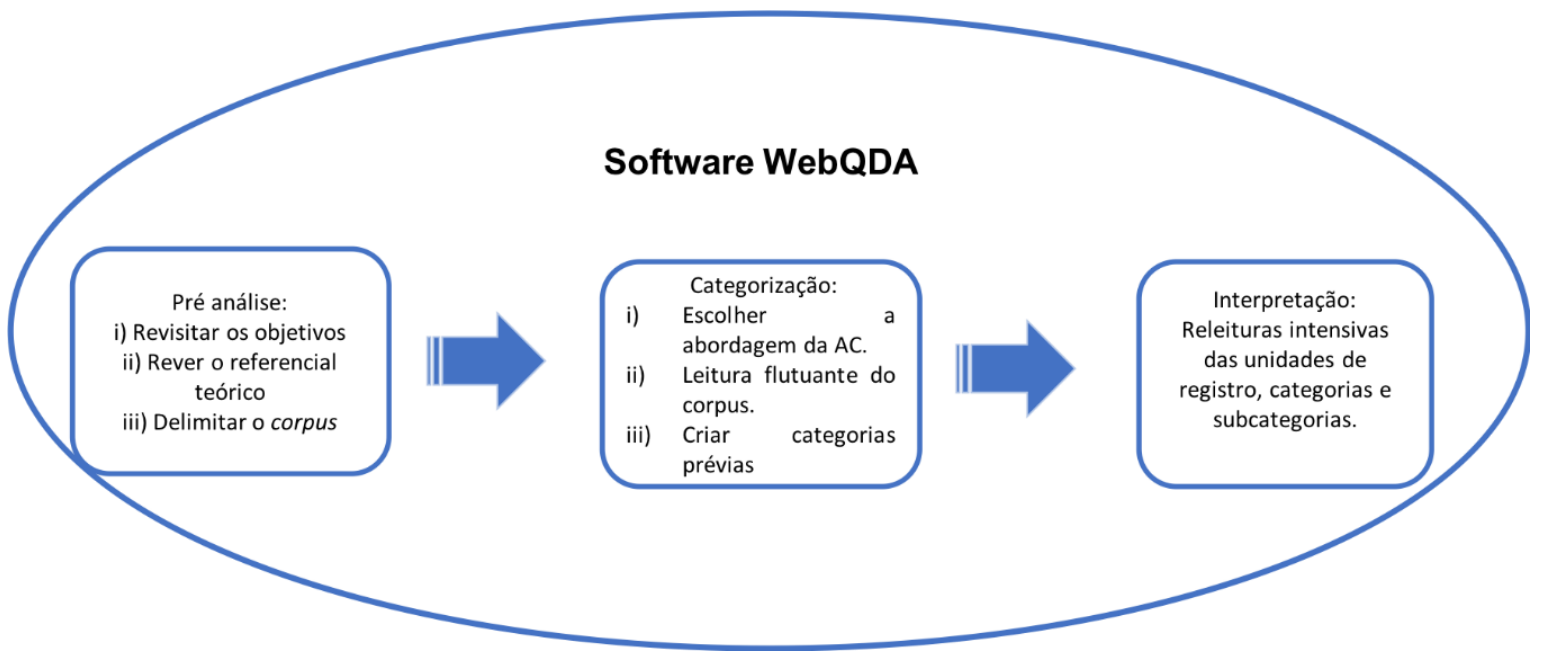

Figura 7 - Procedimentos para a análise de conteúdo. Fonte: Elaboração própria. 


\section{4}

\section{Descrição dos Dados}

Nas sessões a seguir, este capítulo apresenta e descreve os dados coletados nos instrumentos da triangulação que corresponde ao questionário e às entrevistas.

Na primeira sessão é realizada a descrição das questões fechadas do questionário, traçando o perfil dos respondentes e uma análise preliminar dos dados. Posteriormente, apresentamos a análise de conteúdo realizada com a questão aberta e seus resultados e interpretações prévias; e em um terceiro momento serão descritos os resultados das entrevistas com os docentes.

\section{1}

\section{Questionário on-line aplicado aos professores do estado do Paraná}

Como já fora aludido no capítulo metodológico, o questionário on-line foi hospedado na plataforma on-line SurveyMonkey e enviado para professores cadastrados no repositório de recursos educacionais da Secretaria Estadual de Educação da SEED-PR. Recebemos o retorno de 712 questionários respondidos, contudo pela resposta a cada questão não ser obrigatória tivemos em média $25 \%$ de dados perdidos ${ }^{14}$, que não foram contabilizados nos procedimentos de análises.

Como mencionamos acima, o questionário foi divido em três categorias, a saber: i) perfil dos respondentes, que buscou traçar a caracterização dos professores; ii) contexto profissional e tecnológico, que objetivou compreender as competências digitais do professor, as tecnologias presentes em seu cotidiano (na prática profissional ou não) e a relação do seu contexto profissional com as tecnologias; e iii) recursos educacionais digitais, que visou captar a atitude do professor com relação aos RED e as práticas pedagógicas realizadas com estes recursos digitais.

\footnotetext{
${ }^{14}$ No anexo II podemos observar o número de dados faltantes em cada questão.
} 
Após a coleta de dados foi realizada uma análise estatística descritiva e inferencial com o auxílio do software Excel e do software Past, cujos resultados serão apresentados a seguir.

\subsection{1}

\section{Bloco "Perfil dos respondentes"}

Analisando as respostas ao questionário percebe-se que $74 \%$ dos professores são do sexo feminino e $26 \%$ do sexo masculino. Com respeito à faixa salarial, 38,3\% declararam receber de 3 a 5 salários mínimos e 31,6\% declararam receber entre 5 a 10 salários mínimos. Comparando com a média salarial de professores em nível nacional, que no ano de 2017 foi de $\mathrm{R} \$ 3501,09$ (INEP, 2018), percebe-se que os professores do Paraná estão levemente acima da média, considerando que seu rendimento se encontra em torno de $\mathrm{R} \$ 4.148,01$ (INEP, 2018). No gráfico 1 podemos verificar de forma mais detalhada a distribuição da faixa salarial dos professores.

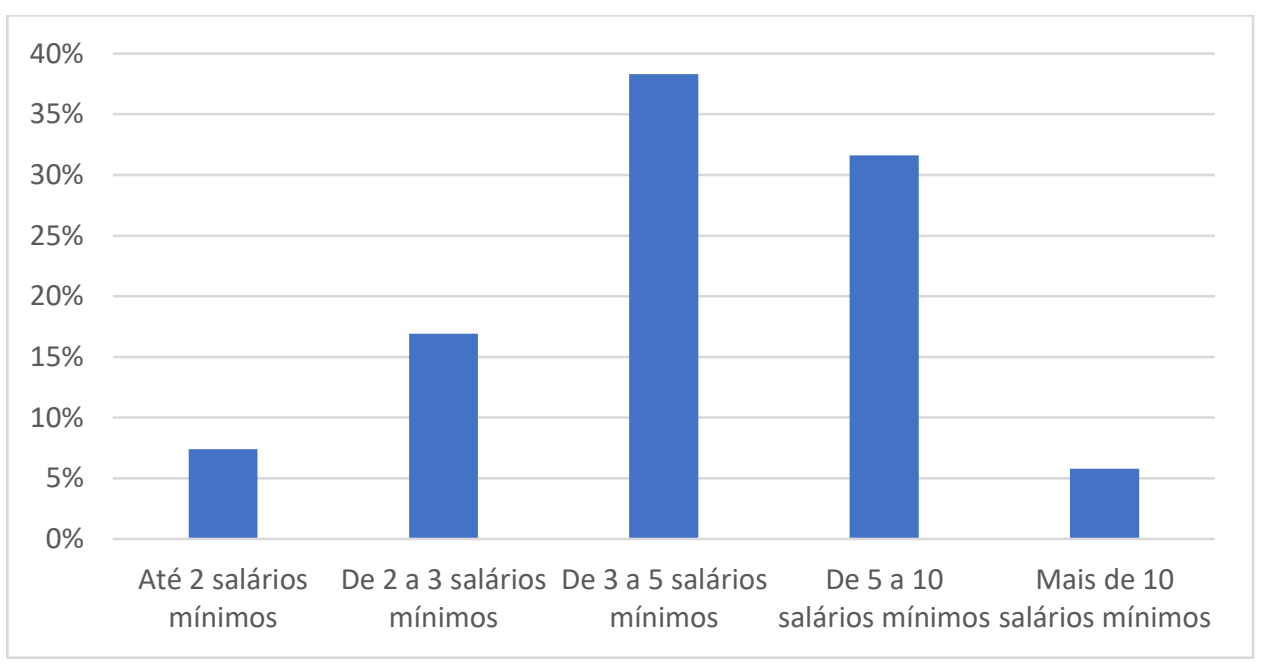

Gráfico 1 - Faixa salarial dos professores. Fonte: Elaboração própria

Com relação a faixa etária, 42,9\% têm entre 30 e 45 anos e 50,6\% têm mais de 45 anos. Quanto ao tempo de docência, 72,8\% afirmaram ter mais de 10 anos de experiência, o que contribui para inferir que os professores conhecem a dinâmica escolar. 
Quanto ao segmento da educação em que atuam, podemos observar no gráfico 2 que os professores se concentram no segundo segmento do ensino fundamental e no ensino médio. Isso era de se esperar pelo repositório de recursos educacionais digitais ser gerenciado pela Secretaria Estadual de Educação, que é responsável pela oferta do segundo segmento do ensino fundamental (junto com as prefeituras) e do ensino médio. Ressalta-se também que o questionário permitia que o respondente optasse por mais de um segmento, o que refletiu em um percentual total de $170,9 \%$, indicando que os respondentes trabalham em 1,71 segmentos, ou seja, $70 \%$ dos professores trabalham em mais de um segmento educacional.

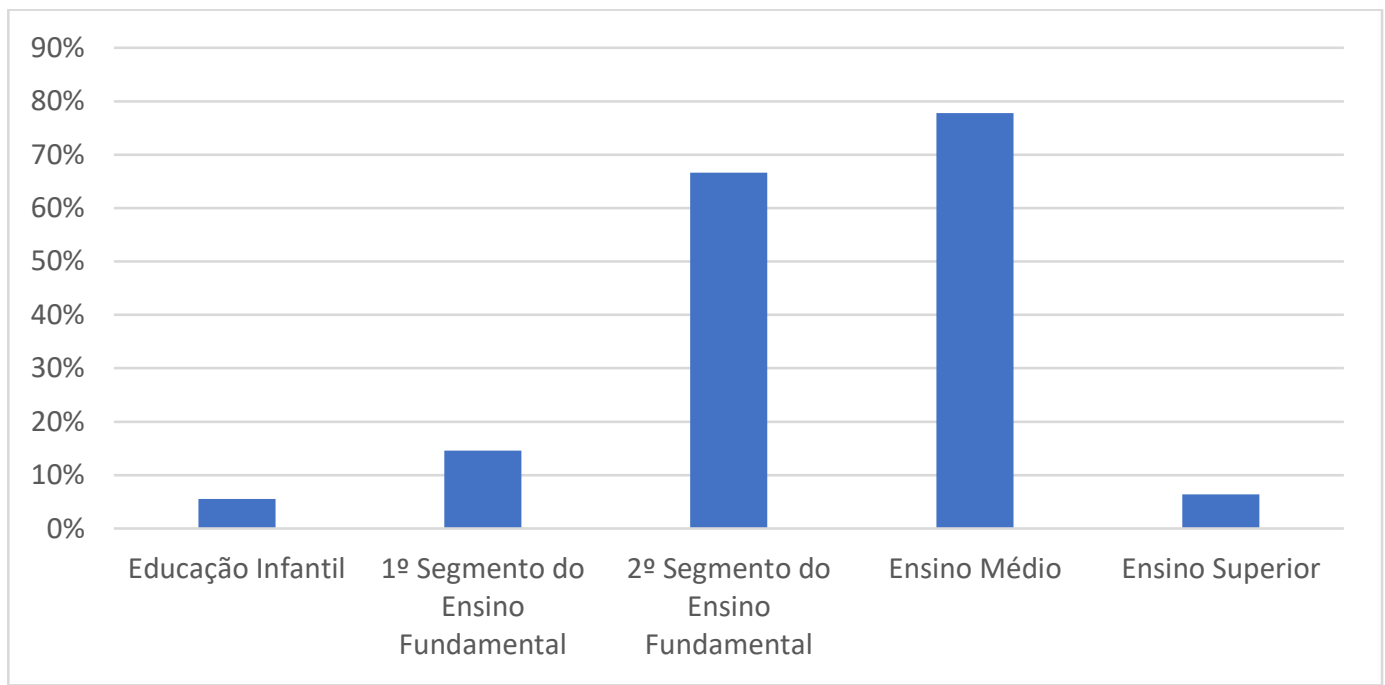

Gráfico 2 - Segmento de atuação dos professores. Elaboração própria.

Com respeito à área do conhecimento em que os professores atuam, o gráfico 3 demonstra que a maior parte dos professores é da área de humanas ou de linguagens. Assim como na questão anterior, a questão 10 permitia que o respondente escolhesse mais de uma opção. Verificamos que o percentual total de 118 indica que ao menos $18 \%$ dos professores parecem atuar em mais de uma área do conhecimento. 


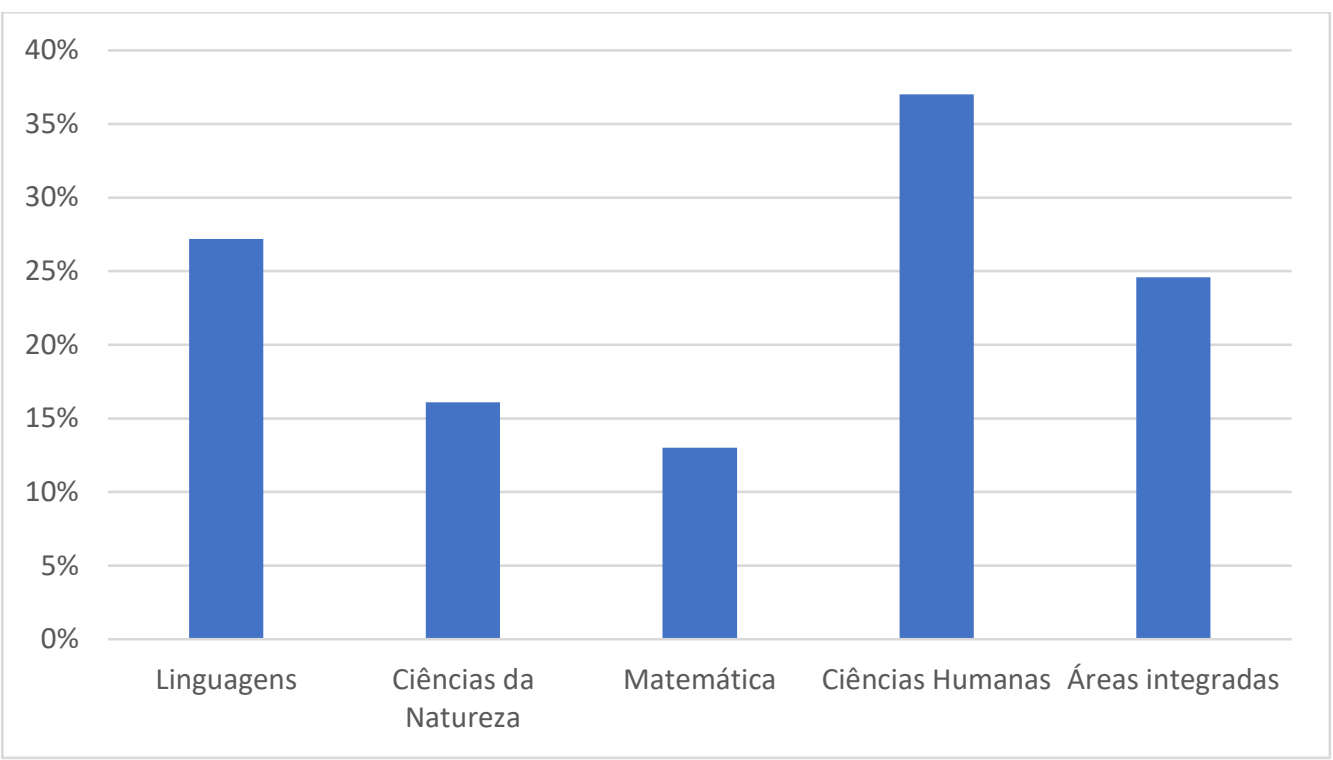

Gráfico 3 - Área do conhecimento em que é docente. Elaboração própria.

Também questionamos aos participantes quanto à sua formação, e os dados explícitos no gráfico 4 mostraram que os professores têm um nível de formação elevada. Podemos observar que 71,9\% dos professores têm pelo menos a especialização, enquanto que 19,3\% têm mestrado ou doutorado.

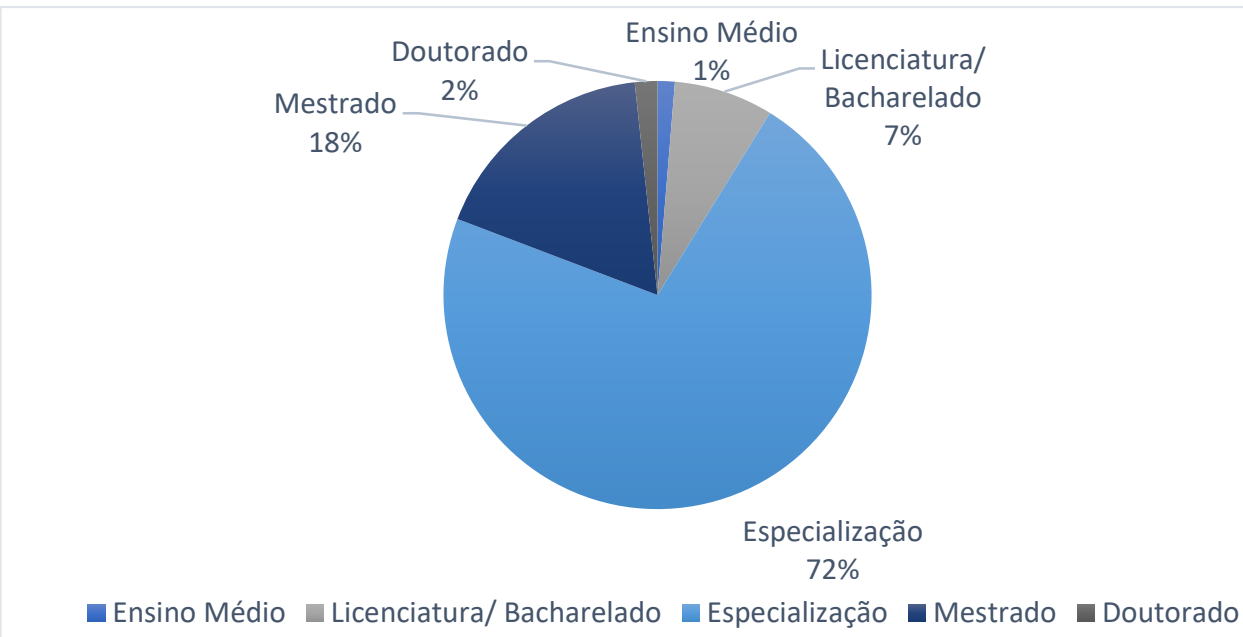

Gráfico 4- Maior titulação de formação. Fonte: Elaboração própria.

Com relação à formação específica sobre as TIC, ao serem perguntados se haviam feito algum curso sobre o tema da educação e tecnologias nos últimos dois anos, $77,5 \%$ dos professores afirmaram que participaram de algum tipo de 
formação continuada. Dos que afirmaram participar, a maioria $(75,5 \%)$ disse que o curso foi oferecido pelo governo e 4,9\% arcaram com as despesas de formação por meios particulares. Ainda, 6,8\% foram oferecidas pela escola, 7,1\% por alguma universidade, $1,7 \%$ por ONG ou empresas e $4,1 \%$ por outro tipo de instituição. Podemos inferir, a partir de tais dados, que parece existir um envolvimento destes professores com a sua formação continuada e seu desenvolvimento profissional. A alta porcentagem dos professores que aderiram às formações oferecidas pelo governo pode indicar também que houve uma preocupação dos órgãos governamentais em traçar melhores práticas educacionais e melhores resultados de aprendizagem com o apoio das TIC.

A análise documental realizada mostrou que a formação continuada sobre tecnologias digitais ofertada pelo estado do Paraná se intensificou a partir de 2007 com a implantação do Programa de Desenvolvimento Educacional (PDE). O PDE estava atrelado ao plano de carreira de magistério, visto que para o professor avançar na carreira presumia-se a participação dos cursos de formação continuada ofertados pela secretaria de pelo menos 200h a cada dois anos (PALAGI, 2004). Nesse sentido, acreditamos que tal política influenciou para que os professores apresentassem um grande percentual de aderência aos cursos de formação continuada com o tema das tecnologias digitais.

Resumidamente, verificamos que os participantes da pesquisa têm em média uma renda salarial superior ao piso nacional, atuam em mais de um segmento de ensino e, em média, em apenas uma área de conhecimento, têm um alto nível de formação e parecem ser implicados com a temática da educação e tecnologia, considerando o número de professores que fizeram formação continuada nesse tema nos últimos dois anos.

\subsection{2}

Bloco "Contexto profissional e tecnológico"

O segundo bloco do questionário visou identificar o contexto tecnológico do professor e caracterizar suas competências digitais e as práticas educacionais 
realizadas com as tecnologias. De acordo com Blau e Shamir-Inbali (2016), o contexto tecnológico reflete como as TIC estão integradas à escola, abrangendo desde os equipamentos tecnológicos que a instituição possui até como as tecnologias são utilizadas pela comunidade escolar, seja em atividades pedagógicas com os alunos ou na construção e compartilhamento de trabalho colaborativo entre professores e gestão.

Na questão 14, com o intuito de conhecer os dispositivos tecnológicos que estão disponíveis no cotidiano profissional do professor, solicitamos que fosse respondido quais tecnologias eram acessíveis e estavam funcionando nas instituições em que atuavam. A partir da tabela 4, ao nos atentarmos para a coluna “\% de casos”, verificamos que as tecnologias "Televisão e vídeo", "Laboratório de informática" e "projetor portátil" são as mais presentes nas escolas. A presença de tais dispositivos pode corresponder aos programas do governo federal e estadual para incorporar tais tecnologias. Os programas Proinfo e Proinfo Integrado, dentre outras atribuições, aparelharam as escolas com televisão e vídeo e posteriormente com laboratórios de informática e projetores portáteis e internet nas escolas (BRASILINO, 2017). Contudo, no caso específico do estado do Paraná, o programa Paraná Digital (BRANCO, CANTINI e MENTA, 2011) se inseriu no âmbito do Proinfo através do Plano de Informática na Escola (PEIE), gerando a implantação de equipamentos e redes, capacitação de recursos humanos, estudos, pesquisa e desenvolvimento de software, alcançando 2.100 laboratórios de informática com conexão à internet de banda larga. Nesse sentido, acreditamos que tais políticas tiveram impacto significativos não só na existência destas tecnologias, mas também na sua manutenção e preservação, visto que, segundo os professores, elas estão em pleno funcionamento.

Com respeito às outras tecnologias, mesmo em um número menos expressivo, verificamos que aproximadamente em $22 \%$ dos casos estão presentes laptops e projetor fixo em sala de aula, e em $20 \%$ dos casos os tablets estão presentes nas instituições, indicando que em algumas escolas existe um aparelhamento diferenciado de tecnologias, mas que no geral as escolas são equipadas. 
Por ser permitido ao professor selecionar mais de uma tecnologia, a porcentagem total de $366,8 \%$ indica que, em média, o professor tem pelo menos 3,66 tecnologias funcionando em sua instituição de ensino.

\begin{tabular}{l|c|c}
\hline $\begin{array}{c}\text { Tecnologias acessíveis para os professores e } \\
\text { estão funcionando na(s) instituição(ções) em } \\
\text { que atuam }\end{array}$ & Respostas & \% de casos \\
\cline { 2 - 3 } $\begin{array}{l}\text { Laboratório de informática } \\
\text { Computador fixo em sala de aula }\end{array}$ & $\mathbf{N}$ & \\
\hline Laptop & 69 & $75,5 \%$ \\
\hline Projetor fixo em sala de aula & 136 & $11,6 \%$ \\
\hline Projetor portátil & 132 & $22,8 \%$ \\
\hline Tablets & 376 & $22,1 \%$ \\
\hline Internet Banda Larga & 123 & $63,0 \%$ \\
\hline Lousa Interativa & 323 & $20,6 \%$ \\
\hline Televisão e vídeo & 91 & $15,2 \%$ \\
\hline Total & 489 & $81,9 \%$ \\
\hline
\end{tabular}

Tabela 4 - Tecnologias acessíveis para os professores na instituição em que atuam. Elaboração própria.

Na questão 15 queríamos saber como era o comportamento dos professores com o uso das tecnologias. Assim, perguntamos a frequência do uso das tecnologias que julgamos mais comuns no cotidiano de um docente. O gráfico 5 mostra que as tecnologias mais utilizadas foram o celular - utilizado todos os dias por $84,10 \%$ dos respondentes, o computador para fins pessoais $-65,3 \%$, e o computador para fins pedagógicos, sendo utilizados todos os dias por $61,8 \%$ dos docentes. Dentre as tecnologias menos utilizadas, o gráfico mostra que 90,3\% dos professores afirmaram não utilizar a lousa interativa, enquanto que $74,5 \%$ disseram não utilizar os tablets. O projetor, que especificamente é uma tecnologia utilizada na maioria das vezes com os alunos em sala de aula, foi representado por 35,2\% dos professores afirmando o uso uma vez por semana, e 21,20\% manuseando essa tecnologia duas ou três vezes por semana. 


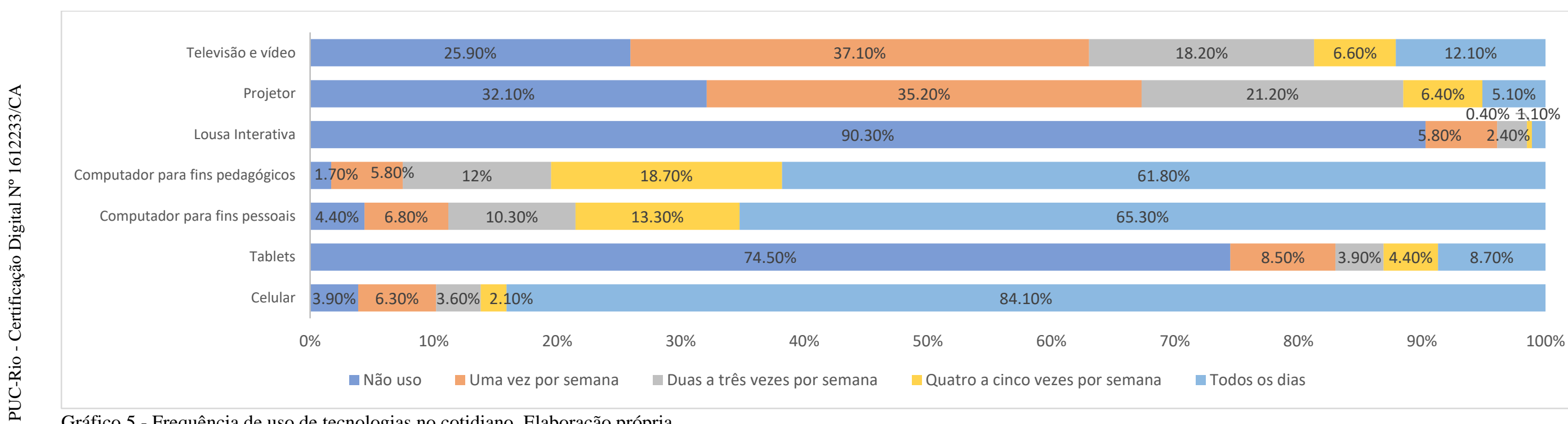


A questão 16 foi formulada com o objetivo de caracterizar as competências digitais dos professores. Podemos observar no relatório estatístico, situado no anexo III desta investigação, que alguns indicadores dizem respeito ao uso geral da tecnologia, enquanto outros se relacionam ao uso pedagógico da tecnologia. Assim, para efeito de análise, reorganizamos os indicadores de forma que pudéssemos considerar os dois tipos de habilidades separadamente, sendo representadas nos gráficos 6A e 6B.

No gráfico 6A verificamos que as atividades mais realizadas pelos professores no geral (uso pessoal e pedagógico) são a realização de downloads e instalação de programas e aplicativos e a modificação de conteúdos disponibilizados na internet. Nestes dois indicadores percebe-se que, respectivamente, $40,6 \%$ e $34,8 \%$ dos respondentes afirmaram realizar estas atividades frequentemente. As ações menos realizadas são as que abrangem noções de programação, chegando a $58 \%$ entre aqueles que realizam isso poucas vezes e as atividades que envolvem edição de vídeo, sendo 54,1 a porcentagem dos participantes que afirmam realizar poucas vezes esta atividade.

Com respeito aos outros indicadores verificamos uma distribuição mais equilibrada entre as frequências com que realizam cada atividade. Vemos que compartilhar conteúdos na internet é realizado pela maioria dos professores, mesmo que em menor intensidade.

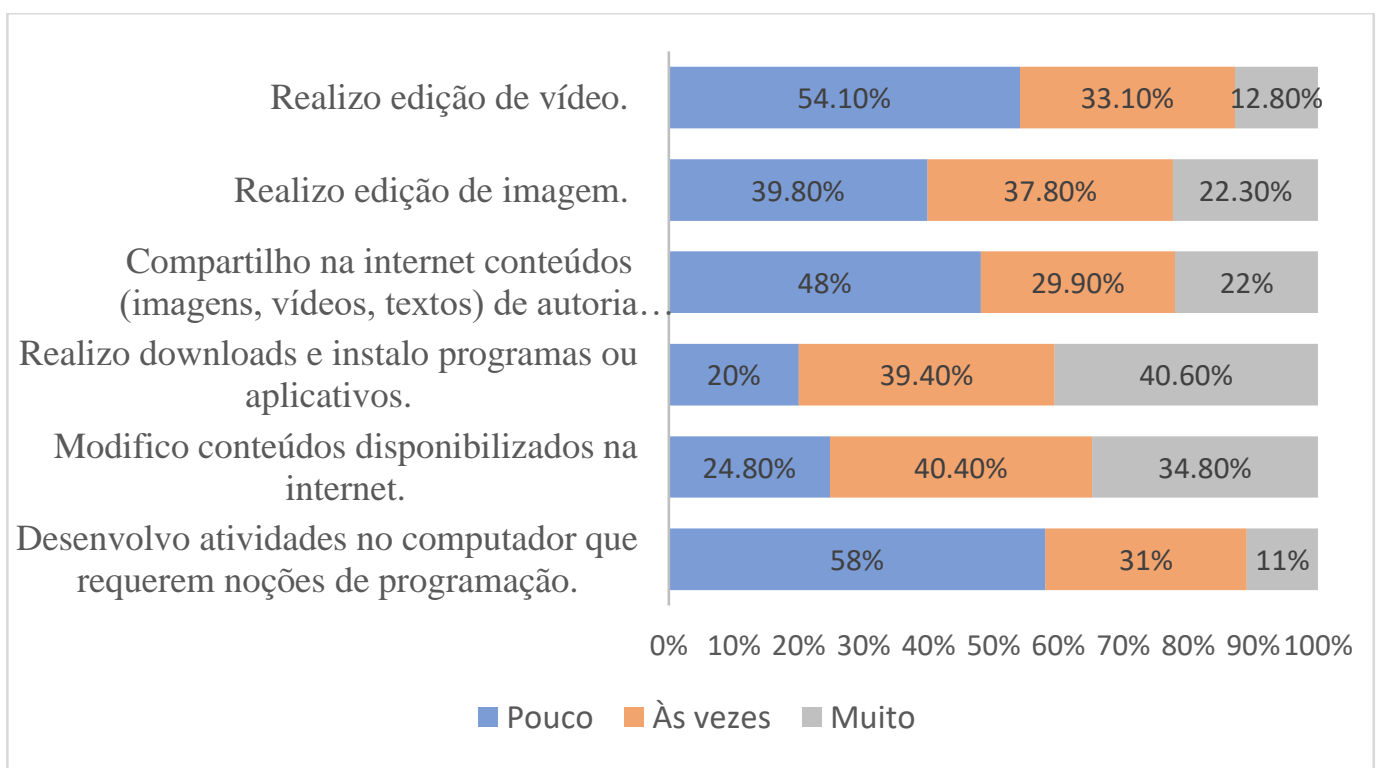

Gráfico 6A - Práticas e atividades tecnológicas. Elaboração própria. 
Em relação aos indicadores que se referem às práticas pedagógicas elaboradas com as TIC, verificamos que as atividades realizadas mais frequentemente pelos professores são a utilização da internet para aprender novas metodologias de ensino, o planejamento de atividades com o computador e a supervisão de pesquisas realizadas pelos alunos na internet. Percebe-se que tais atividades exigem uma competência tecnológica do professor menos complexa (INSTERFORD; MUNTHE, 2016), sendo esse um fator que pode justificar o grande número de respostas dos que realizam tais práticas muitas vezes.

Por outro lado, atividades como criação e/ou edição de vídeos com os alunos e o desenvolvimento de produção midiática com os alunos são atividades com pouca aderência dos professores, especialmente se considerarmos os professores que responderam a frequência de "muito". Percebe-se que as atividades que envolvem criação de conteúdo em sala de aula com os alunos e que, portanto, necessitam de competências digitais mais complexas, são raramente realizadas. Segundo Insterfjord e Munthe (2016), o conhecimento técnico de como se utilizar as TIC faz parte das competências digitais do professor e diz respeito também à compreensão das condições necessárias para utilizar uma tecnologia específica no ensino. Os autores defendem que faz parte das competências digitais a fluência tecnológica ou as condições necessárias para que um professor consiga utilizar uma tecnologia específica no ensino. Compreende-se que faz parte da fluência tecnológica o conhecimento para a utilização do software e a relação entre o conteúdo (conhecimento escolar) e a tecnologia.

A partir da análise dos dados do gráfico $6 \mathrm{~A}$ podemos traçar um perfil das competências tecnológicas que caracterizam os professores participantes da pesquisa. Observamos na figura 8 a existência de três grupos de práticas que foram construídos, considerando a frequência com que os professores realizam cada uma delas. Nesse sentido, o primeiro grupo trata de atividades que são realizadas por mais professores e que também requereria um menor nível de complexidade, e o grupo 3 refere-se às atividades que requerem um nível maior de competências digitais, sendo realizado por um número menor de professores. 
Figura 8 - Grupos de competências digitais. Fonte: Elaboração própria.

O gráfico 6B considera as práticas pedagógicas realizadas com TIC. A partir de sua análise, verificamos que as atividades que envolvem colaboração são desenvolvidas mais frequentemente do que atividades que envolvem produção de conteúdos com os alunos. Os dados que são oriundos dos itens "planejo atividades que permitem aos alunos trabalharem colaborativamente com o uso de tecnologias" e "utilizo o ambiente virtual de aprendizagem para criar atividades com os alunos" mostram que um número maior dos professores respondentes tem considerado as TIC como estratégia de ensino para o trabalho colaborativo.

O mesmo movimento percebe-se no item "adoto formas em que o aluno possa apresentar uma produção por meio das tecnologias”, pois trata-se de um indicador de estratégias pedagógicas que visa a flexibilização de atividades avaliativas. Isso nos leva a acreditar que os professores estão desenvolvendo práticas educacionais diferenciadas com a integração das TIC. Se considerarmos os professores que afirmam realizar tal atividade "às vezes" e "muito" temos que 64,4\% adotam essa mesma estratégia pedagógica em sua prática educacional.

Os itens "utilizo a internet para aprender novas metodologias de ensino" e "planejo atividades em que preciso utilizar o computador" foram as atividades apontadas como as realizadas mais frequentemente pelos professores. Verifica-se que apenas $6,3 \%$ e $14,7 \%$ dos professores, respectivamente, apontaram realizar tais atividades poucas vezes. Isso indica que os professores se sentem mais confortáveis 
em utilizar as tecnologias para atividades ligadas ao planejamento pedagógico, pesquisas e formação continuada.

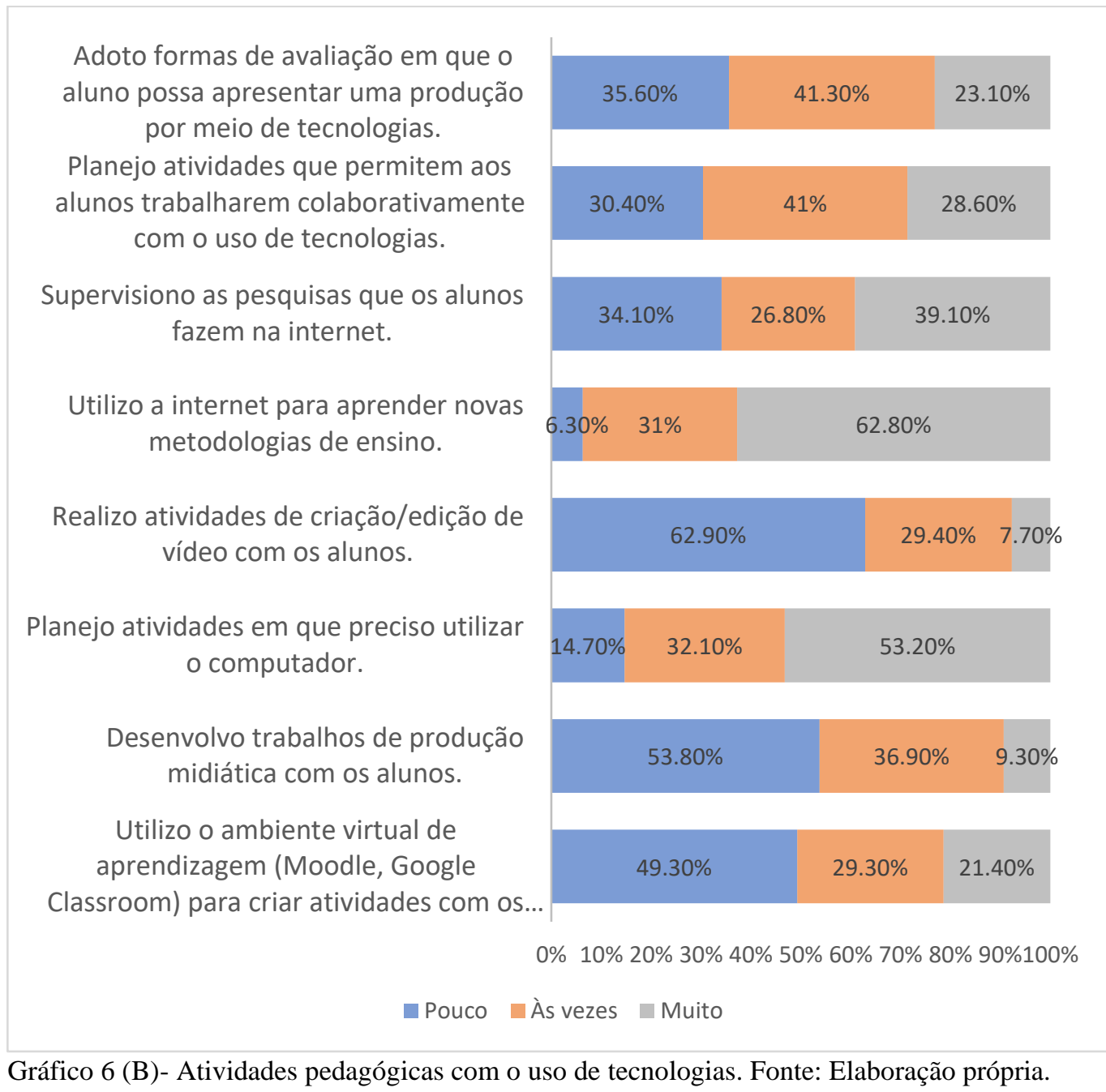

Na figura 9 notamos diferentes agrupamentos com os tipos de atividades realizadas com a integração das TIC, de acordo com a complexidade das competências digitais requeridas. Assim, percebemos que as atividades realizadas com maior frequência pelos professores como utilizar a internet para aprender novas metodologias, ou a realização de planejamentos de atividades em que se precisa utilizar o computador são práticas que necessitam de competências digitais menos complexas. Analisando os grupos de práticas elaborados a partir dos dados, verificamos que quanto maior a complexidade das atividades pedagógicas com o uso da tecnologia, menor a frequência dos professores que realizam tais práticas e maiores as competências digitais necessárias para o seu desenvolvimento. 


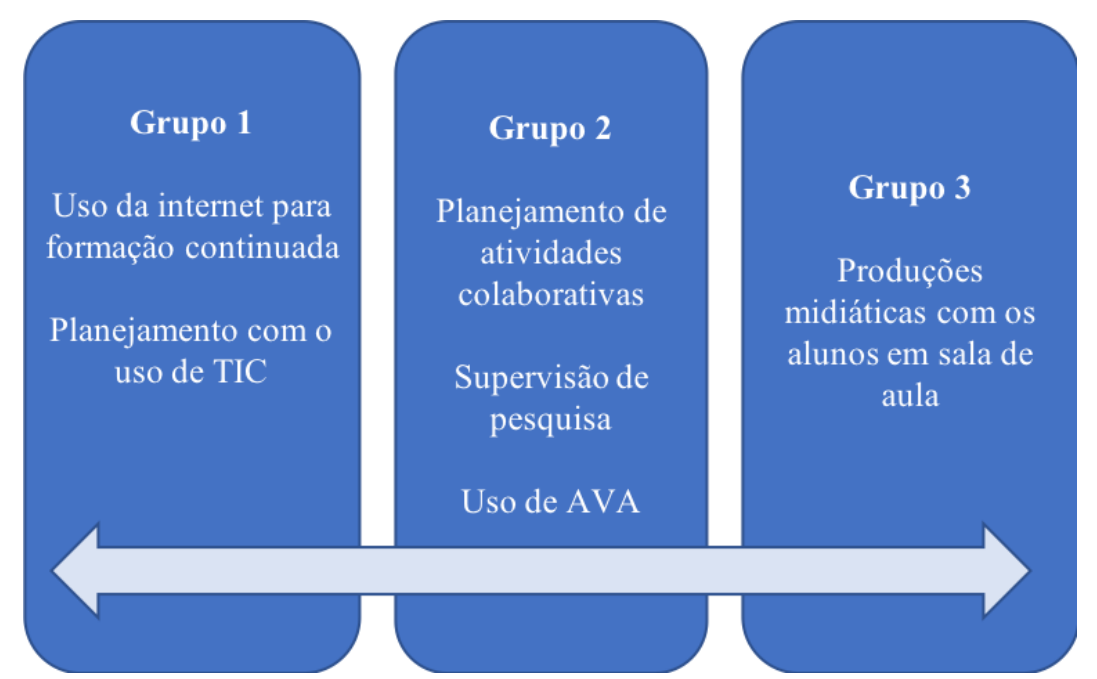

Figura 9 - Grupo de práticas pedagógicas com TIC. Fonte: Elaboração própria.

Na questão 17 tínhamos como objetivo compreender como é a relação da instituição na qual o professor está inserido com as tecnologias, e a atuação do professor em seu contexto profissional com respeito ao compartilhamento de atividades pedagógicas com o uso de tecnologias. Os dados evidenciam que em $84 \%$ dos casos o tema das tecnologias aparece nas reuniões de professores "às vezes" ou "muitas vezes", o que pode indicar envolvimento do corpo docente com essa temática. Isso pode se confirmar pelo indicador "[as tecnologias] são compartilhadas e têm seu uso pedagógico incentivado pelos professores", onde mostra que pelo menos $75,5 \%$ dos professores têm o hábito de compartilhar práticas pedagógicas com o uso das TIC.

Quantos aos indicadores que se relacionam à gestão pedagógica, verifica-se que em $43,7 \%$ dos casos o planejamento educacional com o uso das tecnologias tem sido desenvolvido muitas vezes. Já com respeito à presença do tema tecnologias nos documentos institucionais da escola, os dados mostraram que está presente de forma considerável em $37,7 \%$ dos casos. Ainda com respeito à integração das TIC ao currículo da instituição, verifica-se que para $34 \%$ dos docentes elas estão bem integradas, e para 38,1\% elas são parcialmente integradas.

Em relação à participação do professor em seu contexto tecnológico, o indicador "promovo formação para o uso das tecnologias na minha instituição" apresenta que apenas 19,2\% dos respondentes marcaram essa opção. No entanto 
essa temática é retomada frequentemente em conversas nas reuniões de professores $(40,4 \%)$ e no compartilhamento de práticas e incentivo dos pares (32\%).

A leitura destes dados nos leva a inferir que os professores aparentam preferir construir novos conhecimentos sobre as TIC a partir da troca de conhecimentos e experiências com seus pares (BRASILINO et al, 2018), do que por meio da promoção de formações institucionalizadas. Percebe-se que existe um esforço para compartilhar e incentivar o uso de tecnologias tanto pela gestão como pelos outros professores, fortalecendo assim uma forma de aprendizagem que é coletiva, contribuindo para o compartilhamento de experiências e para o desenvolvimento de estratégias de ensino.

Na questão 16, em relação às práticas desenvolvidas pelos professores com as TIC, vimos que $62,8 \%$ dos professores utilizam a internet para aprender novas metodologias de ensino, assim essa forma de aprendizagem parece converter-se no fortalecimento de uma comunidade de aprendizagem com os pares.

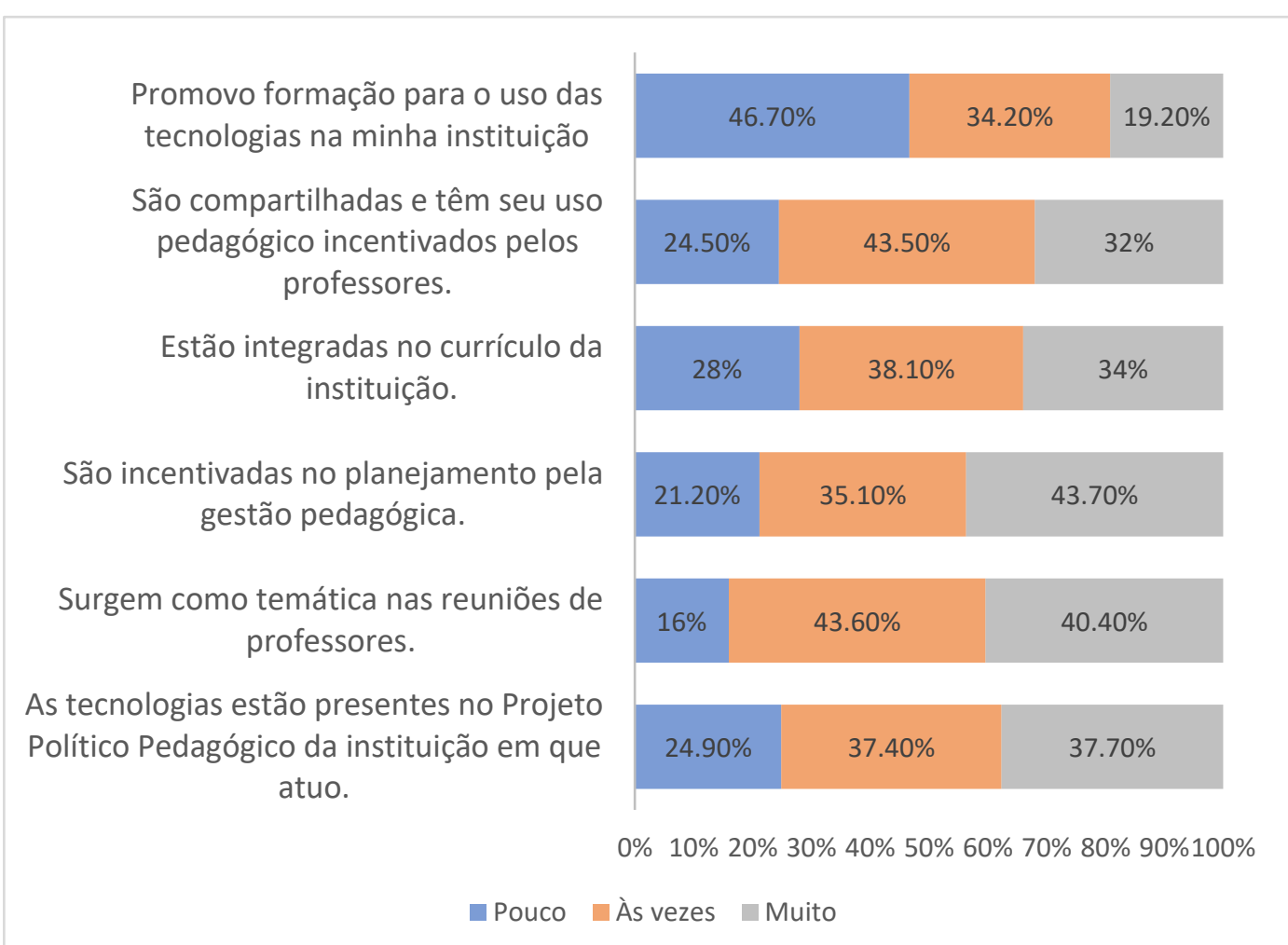

Gráfico 7- Relação entre o contexto de trabalho e tecnologia. Fonte: Elaboração própria. 
Percebemos, analisando o bloco "contexto profissional e tecnológico", que grande parte dos professores atua em um ambiente profissional em que consegue ter trocas contínuas com os seus pares e o apoio da gestão para o uso das tecnologias em práticas educativas, contribuindo para um contexto tecnológico em que há uma presença significativa das TIC na instituição de ensino. Ao mesmo tempo, verificase que os professores que conseguem desenvolver práticas e atividades tecnológicas menos complexas, como apontado na figura 9, têm consciência da relevância da tecnologia em sua prática pedagógica e demonstram interesse em explorá-la para melhorar a sua prática profissional. Compreende-se também que as atividades ligadas ao planejamento escolar são as mais realizadas pelos professores com o uso da tecnologia.

Contudo, notamos que alguns professores demonstram competências suficientes para integrar atividades com as tecnologias digitais no trabalho com os alunos em sala de aula, seja na flexibilização de atividades avaliativas, produção e edição de conteúdo, trabalho colaborativo, ou no uso de ambientes virtuais de aprendizagem. Isto pode indicar o crescimento de práticas que se diferem do planejamento e o desenvolvimento de competências digitais docentes que pressupõe habilidades no uso técnico-pedagógico da tecnologia com foco na sala de aula.

\subsection{3}

\section{Bloco "Recursos Educacionais Digitais"}

O último bloco do questionário tinha como proposta especificar os tipos de recursos educacionais digitais utilizados pelos professores e as práticas realizadas com esses recursos, identificar a atitude do professor com relação aos RED, e mapear as práticas autorais e de compartilhamento que professores realizam com os recursos.

Na questão 18 tivemos a intenção de identificar os tipos de RED mais pesquisados e utilizados pelos professores, assim solicitamos aos respondentes que os classificassem conforme o seu grau de importância, sendo 1 para o mais 
importante e 10 para o menos importante. Na tabela 5 podemos observar o comportamento das respostas dos professores quanto aos RED mais utilizados. 


\begin{tabular}{|c|c|c|c|c|c|c|c|c|c|c|}
\hline & Vídeos & Textos & Jogos & Apresentações & Simulações & Podcast & $\begin{array}{l}\text { Imagens/ } \\
\text { ilustrações }\end{array}$ & $\begin{array}{c}\text { Objetos } \\
\text { multimídias }\end{array}$ & $\begin{array}{c}\text { Planos de } \\
\text { aula }\end{array}$ & $\begin{array}{l}\text { Conteúdo para } \\
\text { avaliação do } \\
\text { aluno }\end{array}$ \\
\hline & $\%$ & $\%$ & $\%$ & $\%$ & $\%$ & $\%$ & $\%$ & $\%$ & $\%$ & $\%$ \\
\hline $\mathbf{1}^{\mathrm{o}}$ & 15,4 & 17 & 17 & 9,8 & 5,3 & 11,3 & 14 & 6,7 & 21,5 & 9 \\
\hline $2^{\circ}$ & 18,6 & 14,3 & 14,3 & 11,4 & 7,7 & 4,3 & 15,2 & 6,5 & 9 & 7,9 \\
\hline $3^{\circ}$ & 12,6 & 12,5 & 12,5 & 14,6 & 7,7 & 3,3 & 14,9 & 9,8 & 7,2 & 12,4 \\
\hline $4^{\circ}$ & 10,7 & 9,8 & 9,8 & 10,4 & 5,6 & 4,3 & 13,2 & 14 & 8,2 & 12,2 \\
\hline $5^{\circ}$ & 8,1 & 9,3 & 9,3 & 12,2 & 9,3 & 5,5 & 11,6 & 13,2 & 11,9 & 14,8 \\
\hline $6^{0}$ & 5,5 & 12,5 & 12,5 & 13,3 & 8,7 & 3,8 & 8,5 & 9,8 & 10,1 & 11,1 \\
\hline $7^{\circ}$ & 6,8 & 7,7 & 7,7 & 10,6 & 10,8 & 2,3 & 6,1 & 14 & 11,4 & 10,3 \\
\hline $8^{\circ}$ & 8,9 & 6,1 & 6,1 & 7,4 & 13 & 9,8 & 6,6 & 12,7 & 6,9 & 10,1 \\
\hline $9^{\circ}$ & 7,3 & 5,3 & 5,3 & 5,6 & 18,8 & 15,1 & 3,6 & 9,1 & 8,2 & 6,3 \\
\hline $10^{\circ}$ & 6 & 5,6 & 5,6 & 4,5 & 13,2 & 40,5 & 6,3 & 4,1 & 5,6 & 5,8 \\
\hline Total & 100 & 100 & 100 & 100 & 100 & 100 & 100 & 100 & 100 & 100 \\
\hline
\end{tabular}

Tabela 5A - Recursos educacionais Digitais mais utilizados. Fonte: Elaboração própria 
Verifica-se que para $21,5 \%$ das pessoas o plano de aula é considerado o recurso mais utilizado, aparecendo como primeira opção. Ao se questionar sobre o recurso mais utilizado como segunda alternativa, observa-se que os vídeos são o segundo mais buscados por 18,6\% dos professores. Já o apontado pelos professores como o menos utilizado é o Podcast, pois foi escolhido por 40,5\% dos respondentes como décima opção na escolha de utilização de RED. Seguindo essa lógica, a tabela 5B organiza a disposição dos RED enquanto critério de escolha pelos docentes.

\begin{tabular}{|l|c|}
\hline \multicolumn{1}{|c|}{ Recurso Digital } & $\begin{array}{c}\text { Porcentagem } \\
\text { dos } \\
\text { respondentes }\end{array}$ \\
\hline $1^{\circ}$ - Planos de aula & 21,5 \\
\hline $2^{\circ}$ - Vídeos & 18,6 \\
\hline $3^{\circ}$ - Imagens / ilustrações & 14,9 \\
\hline $4^{\circ}$ - Objetos multimídias & 14,0 \\
\hline $5^{\circ}$ - Conteúdo para avaliação do & 14,8 \\
\hline aluno & 13,3 \\
\hline $6^{\circ}$ - Apresentações & 14,0 \\
\hline $7^{\circ}$ - Objetos multimídias & 13,0 \\
\hline $8^{\circ}$ - Simulações & 18,8 \\
\hline $9^{\circ}$ - Simulações & 40,5 \\
\hline $10^{\circ}$ - Podcast & \\
\hline
\end{tabular}

Tabela 5B- Recursos educacionais digitais mais utilizados. Fonte: Elaboração própria.

O plano de aula, sendo o recurso digital mais utilizado, reforça os dados encontrados na questão 16 , visto que evidencia que a maior parte dos professores utiliza frequentemente as TIC para atividades ligadas ao planejamento pedagógico. Indo na mesma direção, o RED considerado mais importante também se relaciona à atividade de planejamento.

Considerando as opções de RED fornecidas aos respondentes, os textos e os jogos não foram avaliados como recursos digitais relevantes. De acordo com a tabela $5 \mathrm{~A}$, referente à questão 18 , apenas $17 \%$ dos respondentes apontaram os textos como recurso mais utilizado. Por outro lado, os RED "objetos multimídias" e "simulações" aparecem duas vezes na hierarquização. Uma hipótese é que os professores podem não reconhecer o texto como um recurso educacional digital e, ainda, os jogos podem ser vistos como algo "mais lúdico" do que educacional. 
Outra razão é que por ter sido uma incorporação relativamente recente na educação, os professores podem não ter experiências consolidadas na utilização do jogo como um RED em suas disciplinas, especialmente se observarmos que a maioria dos professores é do segundo segmento do ensino fundamental ou ensino médio.

Na pesquisa de Castro (2014), os recursos mais procurados em repositórios pelos professores foram os recursos multimídias (integração de imagem, texto e som) $\left(1^{\circ}\right)$, seguidos pelos textos $\left(2^{\circ}\right)$ e apresentações $\left(3^{\circ}\right)$. Já nas pesquisas realizadas pelo Cetic.br verifica-se que no levantamento realizado no ano de 2014 os recursos mais buscados foram as imagens $\left(1^{\circ}\right)$, seguidas por conteúdo para avaliação $\left(2^{\circ}\right)$, busca por textos $\left(3^{\circ}\right)$ e vídeos $\left(4^{\circ}\right)$ (CETIC, 2014). Na pesquisa realizada no ano posterior, os professores apontaram como recursos mais utilizados os conteúdos para avaliação do aluno $\left(1^{\circ}\right)$, seguidos por textos variados $\left(2^{\circ}\right)$, pela busca de imagens, ilustrações ou fotos $\left(3^{\circ}\right)$ e notícias $\left(4^{\circ}\right)$ (CETIC, 2015).

Constata-se uma mudança no padrão dos RED utilizados, pois os recursos educacionais apontados pelas pesquisas do TIC Educação (CETIC, 2014; 2015) estão mais relacionados com atividades com maior propensão de não utilizar as TIC como conteúdo para avaliação do aluno, uso de textos e imagens. No entanto, os dados desta pesquisa mostram que, embora ainda sejam mais utilizados os RED para o planejamento de atividades educacionais, são também utilizados para serem trabalhados em sala de aula com os alunos, como é caso dos vídeos e objetos multimídias, se assemelhando mais aos resultados encontrados por Castro (2014).

Na questão 19 nos interessávamos em compreender a percepção dos professores sobre os RED e as possíveis motivações para o seu uso. Observando globalmente os indicadores que formam esta questão, verificamos que os professores possuem uma visão positiva em relação ao seu uso.

A utilização dos recursos na prática pedagógica está ligada com a percepção que os professores têm de conseguirem elaborar aulas mais interessantes, promover novas oportunidades de aprendizagem para os alunos e aumentar a motivação dos alunos para aprender, deixando-os mais interessados na aula (TERUYA et al., 2013; MURPHY e WOLDENFEN, 2013; BLISS et al., 2013).

Outro fator exposto é a relação do uso dos RED com a adoção de novas metodologias de ensino e a reflexão sobre a prática educacional já exercida pelo 
professor. Observamos que $74,2 \%$ dos professores concordam que conseguem inserir recursos em seu planejamento, $86,9 \%$ acreditam que as atividades que realizam com os RED influenciam na adoção de novos métodos de ensino, e 78,8\% avaliam que o uso de RED motiva o professor a repensar a sua prática pedagógica. Os altos índices positivos nos dados nos levam a ponderar se existe alguma ligação entre a inovação pedagógica e o uso de RED. Resultados semelhantes a estes foram percebidos em outras pesquisas sobre os impactos dos recurso educacionais, dentre tais, que o uso de RED contribui para o desenvolvimento de novas estratégias pedagógicas (KWAK, 2017), para a criatividade do professor e contextualização curricular (BLOMGREN, 2018), e para o estímulo à reflexão dos professores com relação à sua prática (WELLER et al., 2015). 
As práticas com os RED dependem do tempo de experiência com o professor.

Minhas aulas ficaram mais interessantes, quando passei a utilizar os RED.

Utilizo RED porque os alunos solicitam.

O uso dos RED motiva os professores a repensarem sua prática pedagógica.

As práticas com os RED dependem da formação do professor.
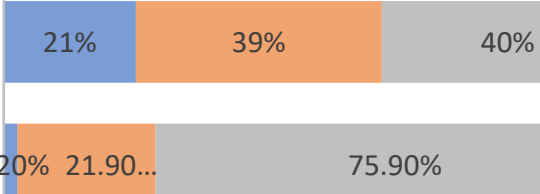

$75.90 \%$

$\begin{array}{lll}35.10 \% & 46.40 \% & 18.50 \%\end{array}$

$2.60 \%$

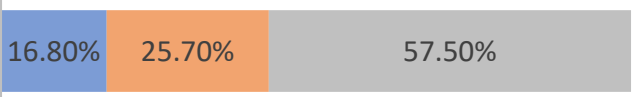

Os alunos ficam mais interessados nas

aulas em que há atividades com RED.

Promovem novas oportunidades para os alunos que não aprendem com métodos tradicionais.

Aumentam a motivação dos alunos para aprender.

As práticas com os RED dependem da experiência prévia com o uso das tecnologias.

Consigo inserir os RED no meu planejamento de ensino.

As atividades pedagógicas com os recursos

influenciam o professor a adotar novos métodos pedagógicos.
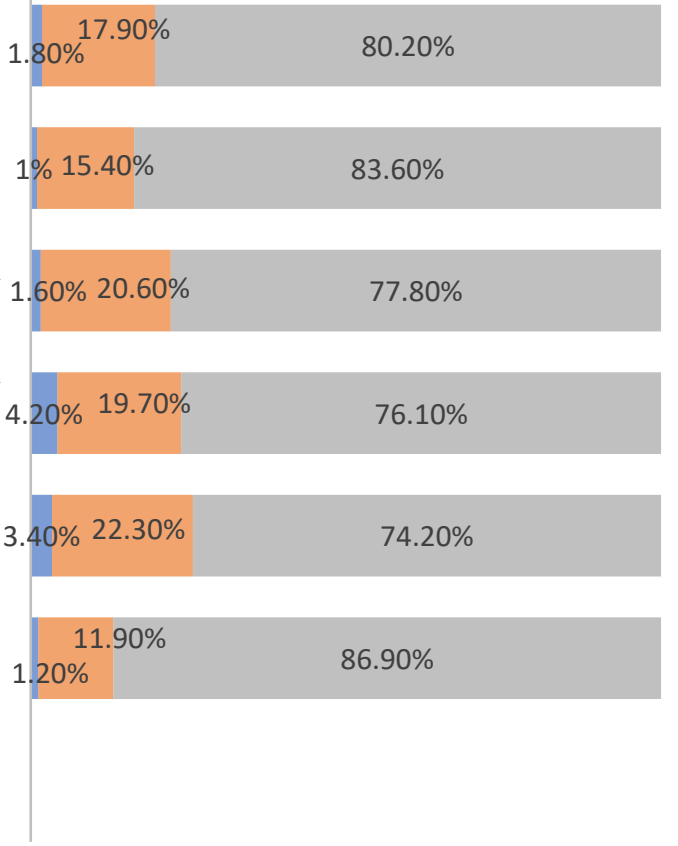

0\% 10\% 20\% 30\% 40\% 50\% 60\% 70\% 80\% 90\%100\%

Discordo Nem discordo/ Concordo

Gráfico 8 - Atitude em relação aos recursos educacionais digitais. Fonte: Elaboração própria.

Os resultados provenientes da questão 19 também nos dão alguns indícios para compreendermos os fatores que poderiam motivar o uso dos RED pelos professores. Percebe-se que os docentes se dividem ao responder se as práticas com os recursos digitais dependem do tempo de experiência no magistério, sendo que para $40 \%$ deles existe uma relação entre o uso de recursos e o tempo de docência, e para $39 \%$ essa relação pode ou não existir.

A relação das práticas com o RED com a formação do professor parece constituir uma ligação mais assertiva, considerando que para 57,5\% dos professores 
existe dependência. No entanto, essa relação de dependência é mais significativa na associação entre a utilização de RED e a experiência prévia que o professor tem com as tecnologias digitais. Para $76,1 \%$ dos professores existe uma relação entre experiência com TIC e uso de recursos digitais, e apenas para 4,2\% dos respondentes essa relação não é significativa.

Nesse sentido, compreendemos que na visão dos professores os fatores que mais se associam ou contribuem para o uso de recursos educacionais digitais são, em primeiro lugar, as experiências anteriores que o professor tem no desenvolvimento de práticas educacionais com o uso das tecnologias digitais, seguidas pela sua formação e por último, o tempo de magistério.

Na questão 20 procurou-se entender as formas de acesso e práticas de compartilhamento que os professores experienciaram em relação aos recursos educacionais digitais. Percebemos que essa foi uma das questões com maior índice de falta de dados, chegando a uma abstinência média de $32 \%$ dos respondentes, que não foram contabilizados nos procedimentos de análise de dados. O alto número de docentes que se absteve de responder a essa questão pode indicar que o compartilhamento de RED não é uma prática recorrente entre os participantes da pesquisa.

Em relação às formas de acesso aos recursos educacionais digitais, o gráfico 9 evidencia que a maior parte dos professores recorre a sites de buscas como principal forma de acesso aos RED. Observamos que 65,6\% dos respondentes afirmam acessar muitas vezes por meio de sites de buscas, enquanto os que costumam acessar "muitas vezes" via repositório de recursos chegam a 35,5\%.

Quanto ao acesso ao tema dos RED por meio de sua formação, 51,9\% dos professores participaram muitas vezes de alguma atividade formativa em que o tema dos recursos educacionais foi abordado. Se considerarmos os que tiveram esse tema tratado algumas vezes, vemos que $83,9 \%$ dos professores participaram de formação em que o tema dos RED foi discutido.

Ao tratar do acesso ao RED através de recomendações de colegas no ambiente profissional, verifica-se que para $44,10 \%$ dos docentes isto ocorre muitas vezes e para 43,1\% ocorre algumas vezes. Tais achados conversam com o indicador "[as tecnologias] surgem como temáticas nas reuniões de professores" da questão 
17, em que 40,4\% dos professores afirmaram abordar o tema das tecnologias em reuniões pedagógicas muitas vezes. Tais resultados reforçam os achados de pesquisas já realizadas (BRASILINO, 2017; MARQUES, 2008, MARTINS, 2007) de que as trocas de práticas educacionais com o uso de TIC que os professores têm em seus contextos influenciam a qualidade de sua atuação docente com as tecnologias, fortalecendo assim uma aprendizagem com os pares.

No tocante às práticas de compartilhamento de recursos educacionais digitais, observamos que o compartilhamento mais realizado é aquele feito com os pares. Cerca de 50\% dos professores recomendam muitas vezes recursos educacionais para colegas de uma mesma instituição. Somando-se aos que afirmam realizar a recomendação algumas vezes, chegamos ao resultado de que 90,2\% dos professores recomendam RED para outros docentes em seu contexto profissional. No entanto, percebemos que essa prática difere quando se trata do compartilhamento de recursos educacionais fora do ambiente em que o professor atua. Apenas 25,1\% dos professores afirmam participar frequentemente de fóruns de discussões on-line ou grupos sobre práticas pedagógicas com RED. Esse número é menor ainda quando consideramos os professores que documentam ou divulgam suas práticas com RED em blogs ou outras plataformas, visto que apenas 6,5\% dos professores afirmam realizar isso muitas vezes e 14,6\% compartilham algumas vezes.

Resultados semelhantes foram percebidos na pesquisa realizada por Algers e Silva-Fletcher (2015). Os autores verificaram que a dimensão coletiva é um dos fatores motivacionais para que professores compartilhem recursos educacionais com os seus pares, sendo a satisfação em moldar a ação significativa entre os participantes com envolvimento mútuo, o principal motivo para o compartilhamento. Também nas pesquisas de Van Acker et al. (2014) e Cetic (2016) foram retratados que os professores eram mais propensos a compartilhar material de forma interpessoal com seus pares em seu contexto profissional, do que em repositórios ou websites. 


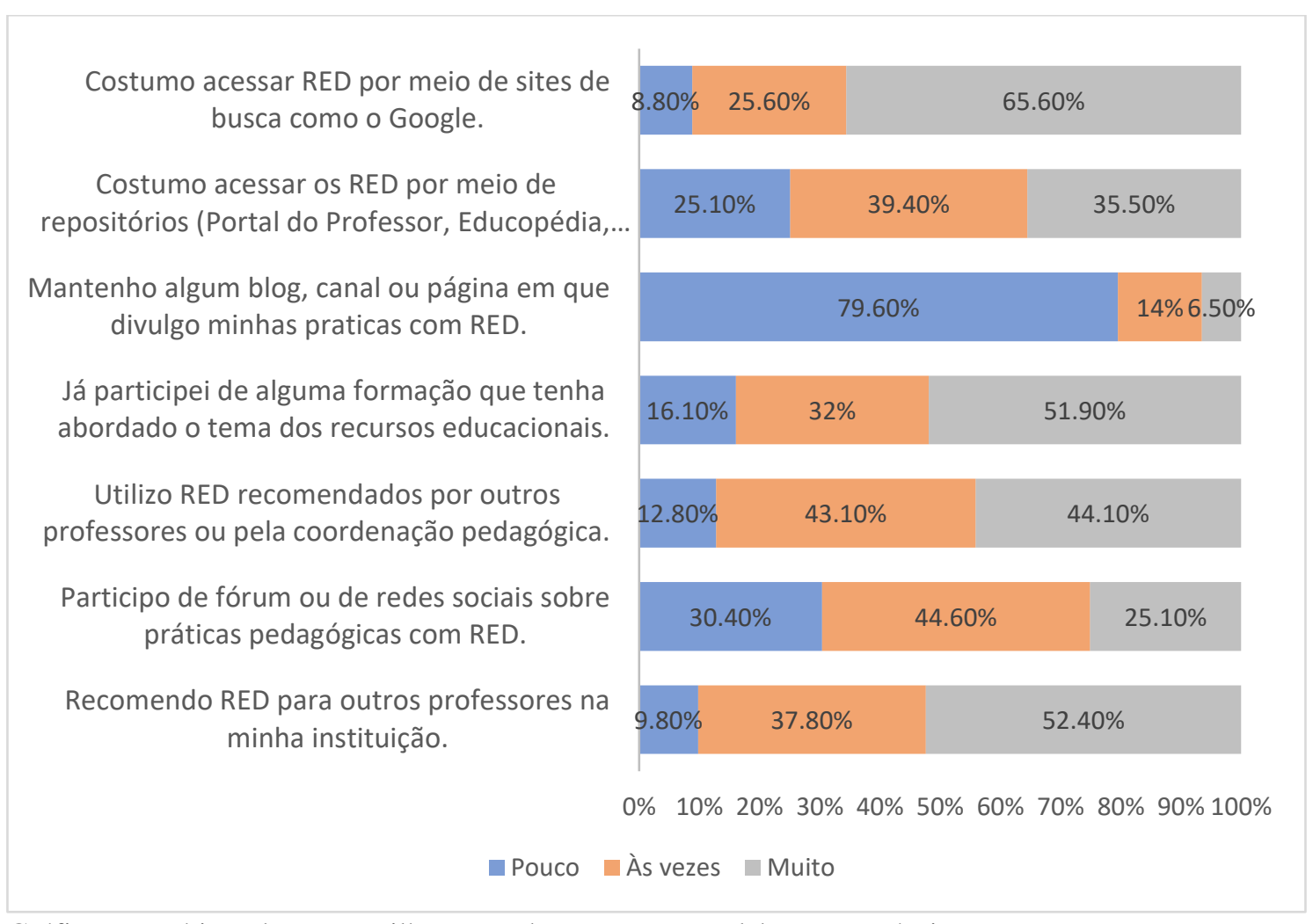

Gráfico 9 - Práticas de compartilhamento de RED. Fonte: Elaboração própria.

Debruçando sobre o tema das produções com os RED, a questão 21 objetiva perceber as práticas autorais que os professores realizam com os recursos digitais. Observou-se que esta questão apresentou o maior grau de absenteísmo, chegando a uma média de $33 \%$ dos respondentes que optaram por não responder. Entendemos que a porcentagem de "não resposta" pode indicar que muitos professores não desenvolvem práticas autorais com os recursos educacionais ou não se reconhecem enquanto autores ao desenvolverem práticas pedagógicas em que seja necessário criação ou modificação de RED. 


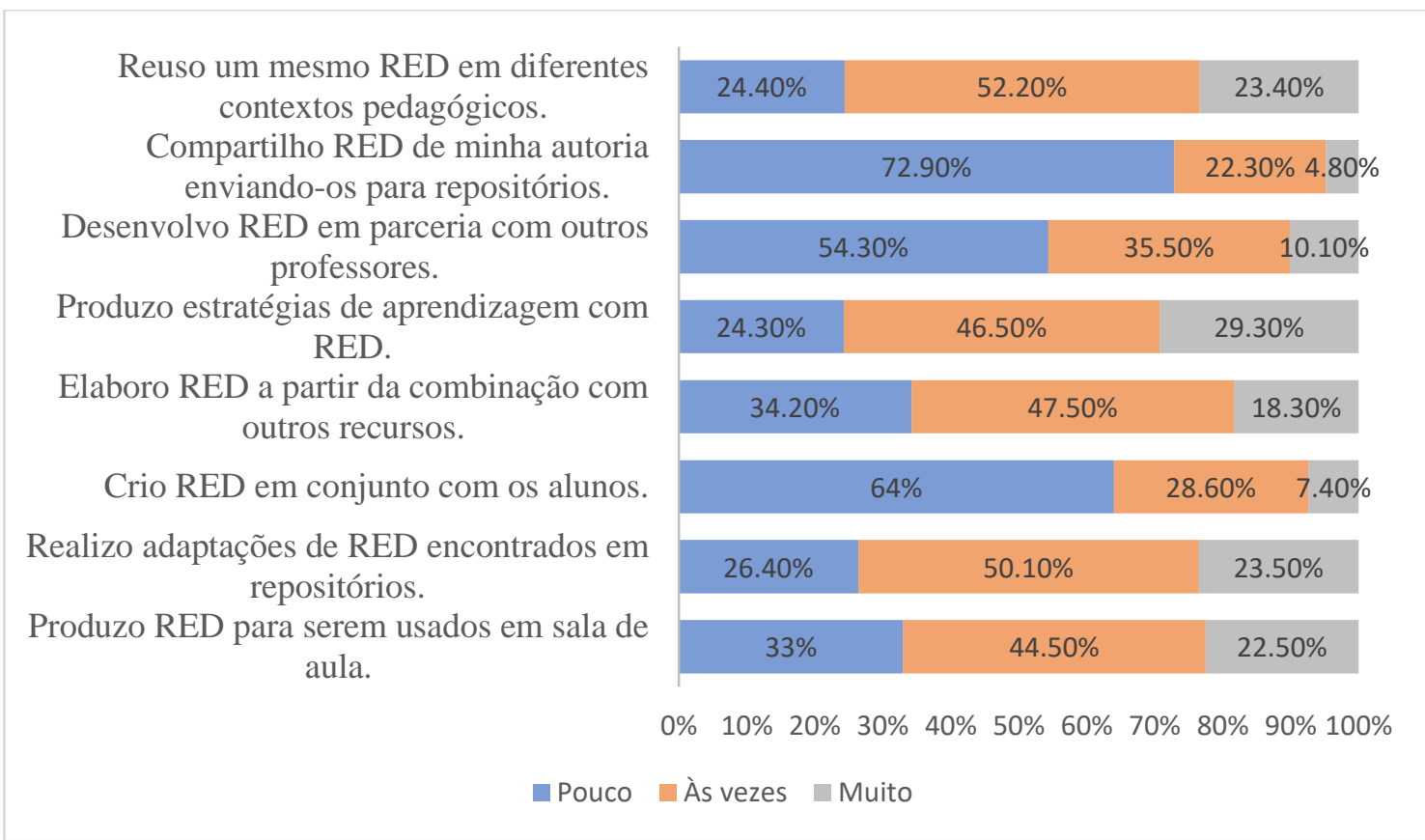

Gráfico 10 - Práticas autorais com RED. Fonte: Elaboração própria.

Analisando os indicadores da questão 21 observamos que poucos professores afirmam realizar práticas autorais com os recursos educacionais. Os dados evidenciam que a prática autoral mais realizada pelos professores é a criação de estratégias de aprendizagem com os RED, sendo desenvolvido frequentemente por quase $30 \%$ dos mesmos. Ressaltamos que, assim como o uso de tecnologias no ensino, esta atividade também está relacionada com o planejamento educacional, reforçando o padrão ou tendência de uso de TIC e RED dos professores.

Outro indicador que se concatena com a prática autoral em atividades de planejamento é o reuso de RED em contextos diferentes de aprendizagem, visto que, embora não tenha modificações físicas, existe autoria, se consideramos que o objetivo pedagógico do recurso pode ser transformado quando o professor o utiliza em um contexto diferente (BEAVEN, 2013).

Com respeito às práticas autorais de RED para serem trabalhados em sala de aula com os alunos, percebemos que as adaptações dos recursos educacionais foram apontadas como as mais realizadas pelos professores, sendo que $23,5 \%$ deles afirmam desenvolver essas práticas muitas vezes. A adaptação de um recurso para um contexto educacional específico foi também indicada por outras pesquisas como a prática autoral mais realizada pelos docentes (CETIC, 2016; HILTON II, WILEY, LUTZ, 2012; MANSON, KIMMONS, 2018). 
Pensando em outra forma de autoria de RED, observamos que 22,5\% dos respondentes afirmam produzir RED para serem utilizados em sala de aula, enquanto que 44,5\% dizem realizar este tipo de produção algumas vezes. Ainda na ótica desta forma de autoria, verificamos que existe outra possibilidade de criação de um novo recurso a partir da combinação de RED já existentes. Sobre este tipo de autoria, 18,3\% dos professores desenvolvem essa prática muitas vezes, enquanto que $47,5 \%$ realizam esse tipo de prática algumas vezes. A autoria de recursos educacionais a partir da combinação de recursos já existentes foi encontrada na pesquisa do Cetic.br na edição de 2016. Nesta ocasião, verificou-se que $82 \%$ dos professores entrevistados afirmaram, pelo menos uma vez, terem criado um novo recurso educacional a partir da combinação de dois ou mais recursos anteriores, se assemelhando ao resultado desta pesquisa ao considerarmos que mais de $65 \%$ dos professores criaram recursos por meio de combinação mais de uma vez.

Nos indicadores que se referem à autoria colaborativa de RED, encontramos que $10,1 \%$ dos professores declaram criar muitas vezes RED em conjunto com outros professores, e apenas $7,4 \%$ o fazem em conjunto com os alunos. O percentual reduzido na autoria coletiva de RED pode se justificar pela necessidade de um conjunto de competências digitais e experiências que são requeridas ao professor para que ele consiga desenvolver autoria com seus pares e alunos.

No contínuo ou fases de adoção de recursos educacionais abertos desenvolvidos por Stagg (2014) constatamos que a co-criação de REA com os alunos foi apontada como última fase de adoção de um recurso. Também no Quadro europeu de competência digital para educadores (DigCompEdu) (REDECKER, 2017) observamos que para a co-criação de RED com os pares é necessário que o educador tenha a competência digital para RED como líder (C1), indicando um nível mais complexo de desenvolvimento de competências. De acordo com o DigCompEdu, nessa proficiência o docente conta com um amplo repertório de estratégias pedagógicas e competências digitais, sabendo escolher as mais adequadas para cada situação em específico, e se mantendo sempre atualizado. Nesse sentido, acreditamos que a complexidade de competências digitais e experiências necessárias fundamentam o baixo número de professores que desenvolvem práticas autorais colaborativas. 
Com respeito ao compartilhamento de RED de autoria do professor, percebemos que apenas $4,8 \%$ dos professores dizem compartilhar recursos de autoria própria. De acordo com o DigCompEdu, compartilhar recursos de autoria própria também envolve um nível de proficiência de competências digitais $\mathrm{C} 1$ ou líder, sendo esse um dos níveis mais elevados. Outras pesquisas (PIRKKALAINEN, PAWLOWSKI, PAPPA, 2017; VAN ACKER et al., 2014; CASTRO, 2014) também apontaram a dificuldade que os professores têm em compartilhar os recursos, sendo essa dificuldade mais complexa quando envolve o compartilhamento em repositórios, visando educadores fora de seu contexto profissional.

A figura 10 nos permite visualizar os tipos de práticas autorais com os RED, a saber: i) utilização de RED para a construção de estratégias de aprendizagem e objetivos educacionais, entende-se aqui como uma prática autoral na atividade de planejamento pedagógico; ii) criação de um novo RED; iii) adaptação de RED, quando, por exemplo, o professor realiza modificações de um RED visando adequar ao seu contexto educacional, e recombinação de RED, quando o docente consegue criar um novo recurso a partir da combinação de dois ou mais recursos; iv) autoria colaborativa de RED, quando o RED é criado a partir de um trabalho com outros professores, gestores ou alunos; v) compartilhamento de RED em repositórios, que se relaciona às práticas de compartilhamentos que os professores têm com os RED criados.

A partir da figura 10 entendemos que quanto mais alto o ponto da espiral, maior é a competência digital e a experiência com RED necessárias para o desenvolvimento das práticas. A espiral da figura também indica um movimento de interdependência e retroalimentação entre as fases, visto que cada prática autoral desenvolvida pelo docente atua como propulsora de novas práticas em um movimento ascendente. 


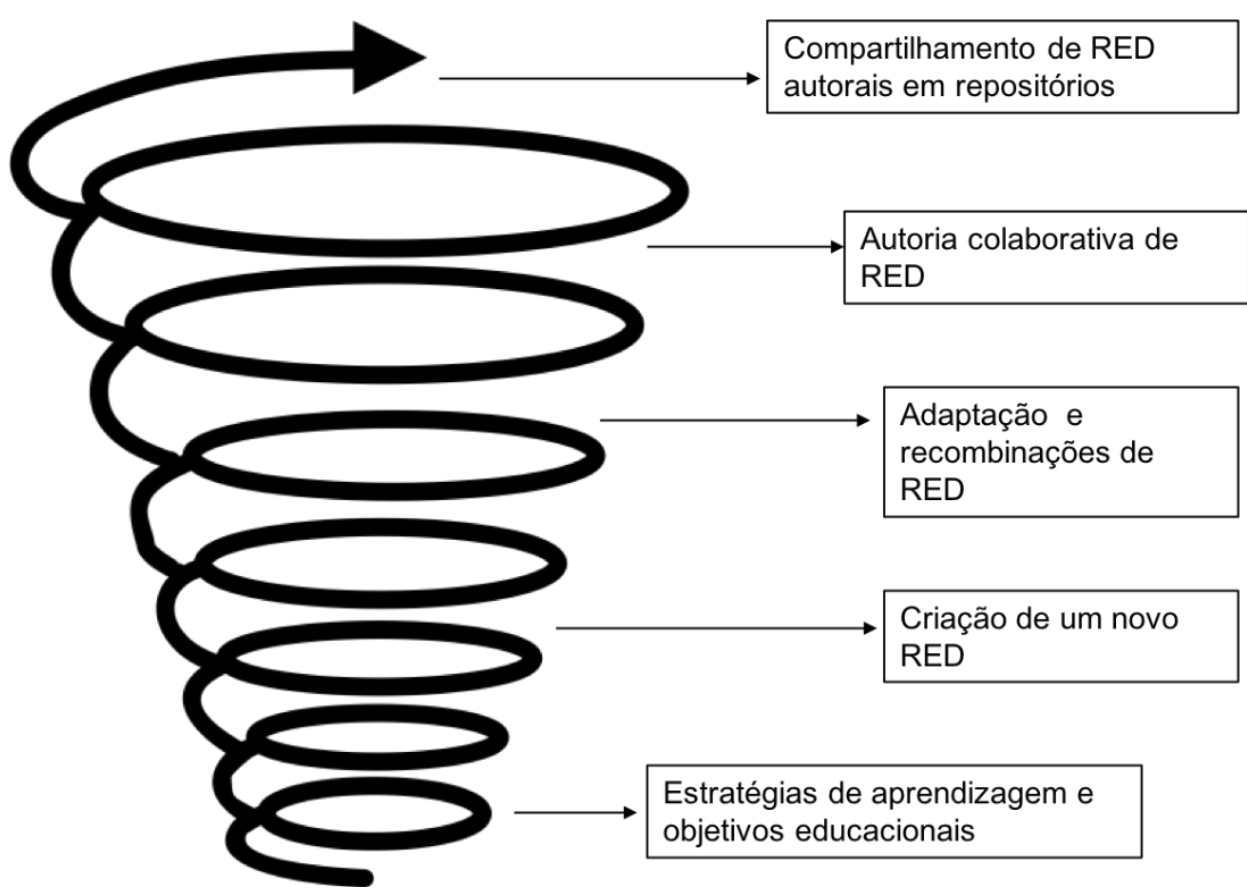

Figura 10 - Fases de práticas autorais com recursos educacionais digitais. Fonte: Elaboração própria.

A análise dos dados oriundos do questionário nos leva a acreditar que existe uma tendência dos professores em utilizar tanto as tecnologias digitais como os RED em práticas ligadas ao planejamento de ensino. No entanto, percebemos que existe um movimento sólido para a utilização de tecnologias em sala de aula, especialmente quando nos voltamos para os usos que os professores fazem do RED, sua percepção sobre esses usos e as práticas autorais que conseguem desenvolver com estes e a partir destes.

\subsection{4}

\section{Análise de correlação entre as dimensões oriundas do questionário}

Retomando as questões de estudo desta pesquisa, intencionávamos saber os níveis de correlação entre a competência digital dos professores e a forma em que os RED são utilizados pelos mesmos. Para tanto, como fora descrito na metodologia da pesquisa, foram criados construtos a partir do agrupamento de indicadores para que fosse possível analisar as correlações entre as já estabelecidas variáveis dependentes e variáveis independentes. 
O quadro 6 contém os resultados dos cálculos de coeficiente de correlação entre os construtos medidos.

\begin{tabular}{|l|l|l|}
\hline & \multicolumn{1}{|c|}{$\begin{array}{c}\text { Práticas de autoria de } \\
\text { Recursos Educacionais } \\
\text { Digitais }\end{array}$} & $\begin{array}{c}\text { Práticas de } \\
\text { compartilhamento de } \\
\text { RED }\end{array}$ \\
\hline Uso pessoal das TIC & $\begin{array}{l}0,4950965 \\
\text { Moderada }\end{array}$ & $\begin{array}{l}0,14215431 \\
\text { Muito baixa }\end{array}$ \\
\hline $\begin{array}{l}\text { Uso das TIC na prática } \\
\text { pedagógica }\end{array}$ & $\begin{array}{l}0,54991995 \\
\text { Moderada }\end{array}$ & $\begin{array}{l}0,23234395 \\
\text { Baixa }\end{array}$ \\
\hline $\begin{array}{l}\text { Uso das TIC na gestão } \\
\text { pedagógica }\end{array}$ & 0,32552468 & 0,22565455 \\
Baixa & Muito baixa \\
\hline $\begin{array}{l}\text { Atitude relativa aos Recursos } \\
\text { educacionais digitais }\end{array}$ & 0,263717 & 0,9648877 \\
Baixa & Muito alta \\
\hline Contexto tecnológico & 0,16317232 & 0,10021166 \\
& Muito baixa & Muito baixa \\
\hline
\end{tabular}

Quadro 6 - Correlação entre os construtos. Fonte: Elaboração própria.

Também foi realizado um teste de significância dos dados dos construtos com a ajuda do software estatístico Past. Segundo Levin e Fox (2004), o nível de significância é calculado para que se possa estabelecer se a diferença amostral obtida é estatisticamente significante. O valor resultante deste teste indica o nível de probabilidade em que a hipótese nula pode ser rejeitada com confiança e a hipótese de pesquisa ser aceita com confiança. Em nosso caso, o teste de significância indicou em que nível as correlações apontadas no quadro 7 podem ser aceitas com confiança.

De acordo com Levin e Fox (2004), a hipótese nula pode ser descartada se existir uma possibilidade muito pequena de a diferença ser consequência de um erro amostral. Os autores explicam que, por convenção, o nível de uma probabilidade pequena é de 0,05 , ou seja, a hipótese nula pode ser rejeitada se uma diferença amostral obtida ocorrer menos de 5 vezes em 100.

Considerando esse nível de significância, percebemos nos resultados do teste indicados no quadro 7 que todos os cáculos de coeficientes de correlação são estatisticamente significantes, pois são menores que o valor de 0,05 , confirmando as hipóteses resultantes do cálculo de correlação. 


\begin{tabular}{|l|l|l|}
\hline & \multicolumn{1}{|c|}{$\begin{array}{c}\text { Práticas de autoria de } \\
\text { RED }\end{array}$} & $\begin{array}{c}\text { Práticas de } \\
\text { compartilhamento de } \\
\text { RED }\end{array}$ \\
\hline Uso pessoal das TIC & $1,532 \mathrm{E}-31$ & 0,0016609 \\
\hline Uso das TIC na prática pedagógica & $2,6148 \mathrm{E}-40$ & 0,00000019783 \\
\hline Uso das TIC na gestão pedagógica & 0,0000000000001559 & 0,00000047239 \\
\hline $\begin{array}{l}\text { Atitude relativa aos Recursos } \\
\text { educacionais digitais }\end{array}$ & 0,0000000028481 & $1,195 \mathrm{E}-286$ \\
\hline Contexto tecnológico & 0,00034571 & 0,028807 \\
\hline
\end{tabular}

Quadro 7 - Teste de significância entre os construtos. Fonte: Elaboração própria.

De acordo com o quadro 6, no construto "Práticas de autoria de Recursos educacionais digitais" o maior nível de correlação é com o construto "Uso de TIC na prática pedagógica", seguido pelo "Uso pessoal das TIC". O cálculo do coeficiente indicou uma correlação positiva moderada, isto é, existe uma relação que se move conjuntamente entre os dois construtos, ou seja, quanto maior o uso das TIC, seja de uso pessoal ou na prática pedagógica, maior será o desenvolvimento de práticas de autoria de recursos educacionais. Embora tenhamos identificado uma correlação moderada, isto não implica em dizer que existe uma relação de causa e efeito, onde quem utiliza TIC na prática pedagógica irá desenvolver práticas autorais com RED, mas se pode dizer que existem semelhanças entre a distribuição dos escores das variáveis (FIGUEIREDO FILHO; SILVA JÚNIOR, 2009).

A relação entre o uso de TIC e as barreiras para a criação de RED também foi encontrada em outras pesquisas (MAZZARDO, NOBRE, MALLMANN, 2019; MCKERLICH, IVES, MCGREAL, 2013; BAGETTI, MUSSOI, MALLMANN, 2017), onde foi abordado que a presença ou a falta de competências pedagógicas dos professores influenciam na criação de recursos educacionais digitais.

No construto "Práticas de compartilhamento de RED" percebe-se uma correlação muito forte com o construto "Atitude relativa aos Recursos Educacionais Digitais". O alto coeficiente de correlação pode ser explicado pelo fato de o professor ao realizar o compartilhamento de recursos digitais seguir fortemente a tendência de ter uma atitude positiva com os usos dos RED. O coeficiente de 0,9 é muito próximo da correlação perfeita, indicando que grande parte dos respondentes 
apresentaram respostas semelhantes nos indicadores que compuseram cada um dos construtos.

Em relação aos coeficientes com baixa ou muito baixa correlação entre os construtos, acreditamos que pode se justificar pela complexidade de competências digitais requeridas para o desenvolvimento das práticas de autoria e compartilhamento de RED. Especialmente na prática de compartilhamento, outros estudos (CLEMENTS; PAWLOWSKI, 2012; BEAVEN, 2013; VAN ACKER et $a l ., 2014)$ demonstraram as dificuldades encontradas pelo professor ao compartilhar um recurso educacional. Entre as dificuldades, identificou-se problemas de compatibilidade curricular, com direitos autorais, variação de conteúdo e a crença de que as mudanças em um RED são muito pessoais para caber nas propostas de outros professores.

Não encontramos elementos que explicassem a baixa correlação entre “Atitude relativa aos RED" e "Práticas de autoria de RED", visto que nossa hipótese era de que o professor ao desenvolver práticas autorais com RED precisaria ter uma atitude positiva em relação aos recursos, traduzido por um alto coeficiente de correlação. Tal relação foi percebida nos estudos de Borthwick e Dickens (2013) e Littlejohn e Hood (2017), que demostraram que os professores que criavam recursos educacionais estavam engajados com esse tema em sua comunidade de práticas. Estes resultados anteriores nos levam à necessidade de investigar a associação entre autoria de RED e atitude em relação ao RED de forma mais profunda durante a análise das entrevistas.

No gráfico 11 podemos comparar os coeficientes de correlação entre os dois construtos que formaram as variáveis dependentes e os construtos que são as variáveis independentes. Verificamos que o construto "Práticas de autoria de Recursos Educacionais Digitais" apresentou os maiores coeficientes de correlações indicando um grau maior de dependência em relação aos outros constructos, enquanto o construto "prática de compartilhamento RED" demonstrou alto grau de dependência exclusivamente do construto "atitude relativa aos RED". 


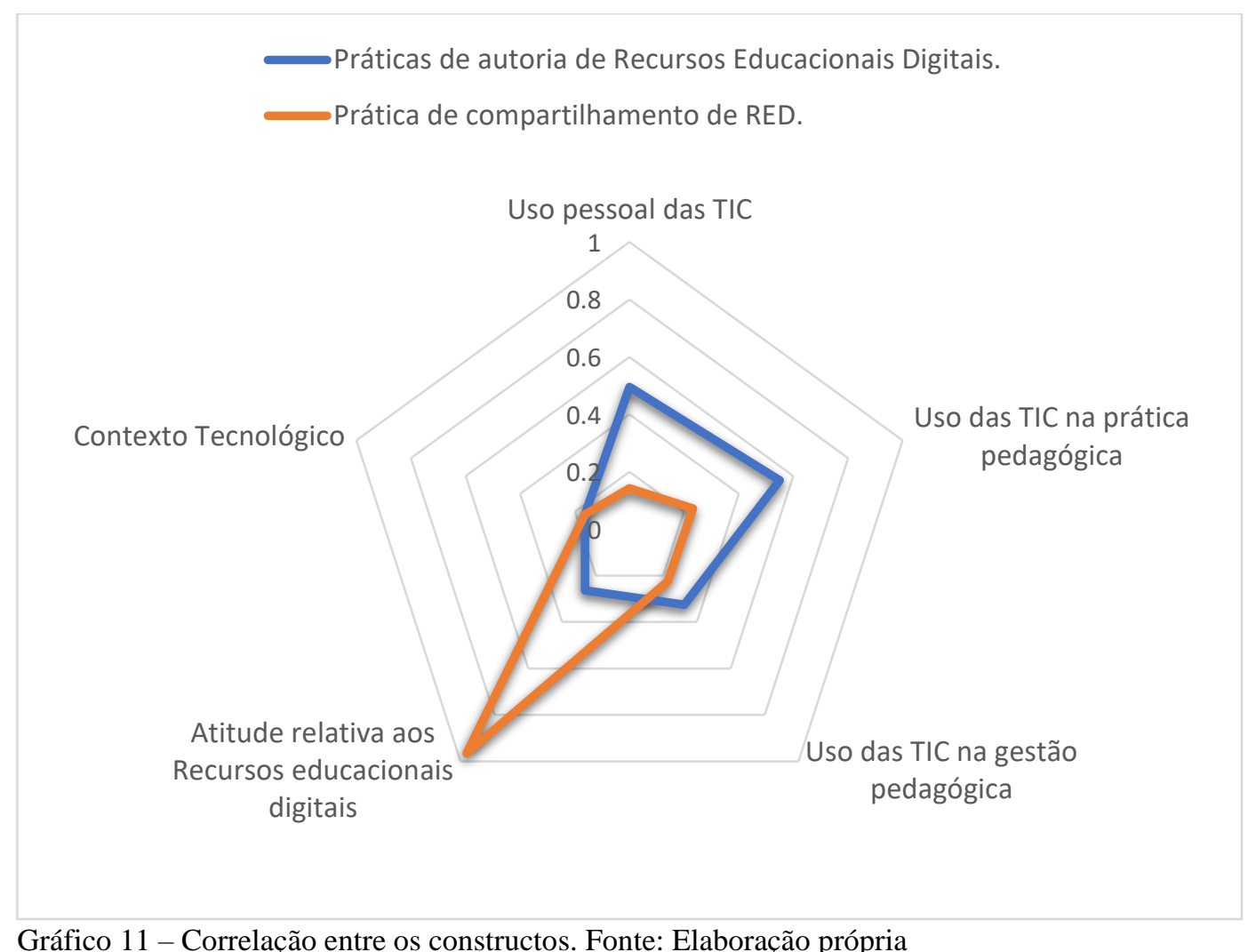

Gráfico 11 - Correlação entre os constructos. Fonte: Elaboração própria

Os coeficientes de correlação do quadro 6 nos indicam que as correlações entre os construtos não foram fortes o suficiente para explicar a relação entre a competência digital e as práticas autorais com os recursos educacionais digitais, levando-nos a acreditar que seja necessário aprofundar estas questões com os participantes da pesquisa por meio de uma abordagem diferenciada, como é o caso das entrevistas.

\section{2}

\section{Análise de conteúdo da questão aberta do questionário}

O questionário contou com uma questão aberta "Por que você utiliza os recursos educacionais digitais?" e teve o retorno de 474 respostas que compuseram o corpus para a realização da análise. Na figura 11 podemos observar a nuvem com as palavras mais citadas pelos respondentes. Verifica-se que as palavras com maior impacto foram "alunos", "aprendizagem", "aulas", "recursos" e "ensino", indicando que a principal motivação do professor para utilizar os recursos 
educacionais digitais está ligada ao processo de aprendizagem do aluno.

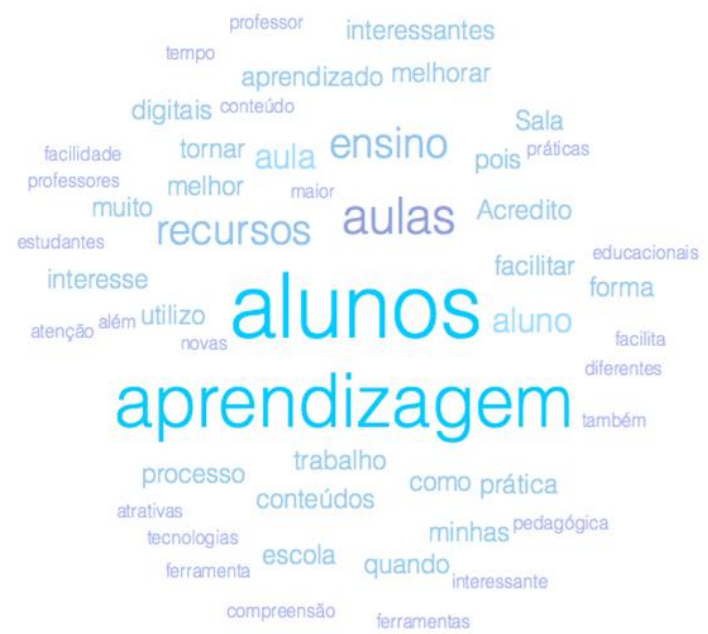

Figura 11- Nuvem de palavras. Fonte: WebQDA.

O sistema de categorias apresentado no capítulo metodológico fundamentou a análise de conteúdo realizada com o apoio do software WebQDA. No quadro 8 observa-se a distribuição das referências ou unidades de registros entre as categorias. Verificamos que as subcategorias que tiveram maior representatividade durante a análise de conteúdo foram "processos e resultados de aprendizagem" e "alteração e inovação de práticas de ensino", demonstrando que a utilização dos RED pelos professores é motivada principalmente pela necessidade de oportunizar aos educandos diferentes experiências para alcançar o aprendizado e para inovar em sua prática docente. 
Categorias Subcategorias Referência

\begin{tabular}{l|l|l}
\hline Aprendizagem & $\begin{array}{l}\text { Processos e resultados de } \\
\text { aprendizagem }\end{array}$ & 114 \\
\hline & $\begin{array}{l}\text { Suporte aos conteúdos } \\
\text { Racionalização no processo de ensino }\end{array}$ & 67 \\
\hline $\begin{array}{l}\text { Desenvolvimento } \\
\text { profissional } \\
\text { docente }\end{array}$ & $\begin{array}{l}\text { Alteração/inovação de práticas de } \\
\text { ensino }\end{array}$ & 119 \\
\cline { 2 - 3 } & $\begin{array}{l}\text { Desenvolvimento de competências } \\
\text { pedagógicas digitais }\end{array}$ & 43 \\
\hline $\begin{array}{l}\text { Inserção } \\
\text { cultura digital }\end{array}$ & \begin{tabular}{l} 
Escola inserida na cultura digital \\
\cline { 2 - 3 }
\end{tabular} & \begin{tabular}{l} 
Aluno inserido na cultura digital. \\
\hline
\end{tabular}
\end{tabular}

Quadro 8 - Referências por categoria. Fonte: adaptado do WebQDA.

Apresentamos os resultados seguindo as categorias analíticas observadas no quadro 8 .

\subsection{1}

\section{Aprendizagem}

A categoria "aprendizagem" representou 42,95\% das referências e foi dividida em três subcategorias: i) processos e resultados de aprendizagem; ii) suporte aos conteúdos; e iii) racionalização do processo de ensino. Percebe-se que é a categoria com maior relevância no corpus dos dados e se relaciona com as estratégias pedagógicas utilizadas pelos professores com os RED. Apresentamos os resultados de cada subcategoria traçando suas interpretações, assim como sua contribuição para os objetivos e alcance da pesquisa.

\section{Processos e resultados de aprendizagem}

A subcategoria "processos e resultados de aprendizagem" trata das práticas e estratégias pedagógicas utilizadas e desenvolvidas pelos professores com os RED a fim de melhorar ou garantir o processo e os resultados da aprendizagem do aluno. 
De acordo com Jeong e Hmelo-Silver (2010, p. 85), os recursos de aprendizagem podem ser utilizados para "ajudar os alunos a fundamentar a aprendizagem, examinar sua compreensão a partir de diversas perspectivas, fazer conexões através de conceitos relacionados e contrabalancear o espaço entre a compreensão teórica e o conhecimento prático”. Nesse sentido, os RED são utilizados pelos professores como recursos mediadores na construção do conhecimento dos discentes.

O desenvolvimento do interesse do aluno pela aprendizagem foi encontrado nas falas dos professores como um dos fatores de motivação para o uso dos RED em sua prática educacional. No entanto, de acordo com Pischetola (2016), apesar de notarmos na sociedade e na escola a ampliação das oportunidades de acesso ao conhecimento e às tecnologias, isso não tem se convertido na ampliação do desempenho escolar. Podemos observar como os professores relacionam sua prática pedagógica com os RED e com o desenvolvimento do interesse do aluno.

Utilizo com intuito de despertar no aluno o interesse de aprender e também para consolidar a aprendizagem. (Indv_323)

Porque facilitam o trabalho, despertam maior interesse dos alunos, entre outros através do dinamismo dos recursos educacionais digitais. (Indv_312)

Por que são atuais e fazem com que os alunos se interessem pelo assunto abordado. (Indv_22)

Porque as aulas ficam mais dinâmicas e os alunos mais motivados. (Indv_462)

Para melhorar o aprendizado dos alunos, pois os mesmos acham mais interessantes aulas com tais recursos e na maioria eles prestam mais atenção quando se usa recursos digitais. Os alunos interagem mais com a aula. (Indv_99)

Para facilitar melhor o entendimento dos alunos, e assim cativar melhor a atençao deles e assim promover o interesse pelo conteúdo (Indv_133)

Porque é mais atrativo para o aluno, fica melhor a apresentação, é uma metodologia diferenciada, pode-se trabalhar com animação, slides... (Indv_303)

Percebe-se nas falas dos professores que parece existir o entendimento de que ao utilizarem os RED existe um maior interesse dos alunos pela aula e pelo conteúdo que está sendo trabalhado. Nos relatos também se verifica o discurso dos professores de que os RED contribuem para uma aula mais dinâmica e atrativa, 
traduzindo-se no aumento do interesse. Cabe aqui ressaltar que isso pode não ser consequência da integração dos RED na prática pedagógica, mas sim, por se tratar de uma proposta pedagógica que se diferencia de um formato mais tradicional de aula expositiva. Nos estudos de Hung et al. (2015) e Harris et al. (2016), ao utilizarem recursos educacionais digitais para investigar seu impacto na motivação dos alunos, os autores observaram que a tecnologia (RED nos respectivos estudos) não aumentava a motivação dos estudantes para aprender. Para os autores, o aumento da motivação estava relacionado com o tipo de abordagem pedagógica utilizada pelo docente com os RED.

Outro resultado nesta subcategoria são as diferentes oportunidades de aprendizagem que os recursos educacionais possibilitam aos alunos, que, de acordo com os professores, corroboravam para o maior interesse do discente no processo de ensino e aprendizagem. Os docentes acreditam que o uso dos RED promove novas formas de aprender e que os alunos são beneficiados pelo uso de abordagens e metodologias diferenciadas para a construção do conhecimento. Tais resultados foram identificados nas seguintes falas:

Utilizo-os, pois compreendo que eles promovem outras formas de interação com o conhecimento. (Indv_293)

Utilizo com intuito de despertar no aluno o interesse de aprender e também para consolidar a aprendizagem através do dinamismo dos recursos educacionais digitais. (Indv_323)

porque colaboram com os diferentes tipos de aprender, respeitando a diversidade dos estudantes (Indv_318)

Possibilitam aprendizados diferenciados e/ou fixação de conteúdos, auxiliam os diferentes níveis de aprendizagem e diferentes tempos dos alunos, especiais por exemplo. Tornam as aulas mais atrativas. (Indv_376)

Porque aprendemos por diferentes canais, diferentes motivações e os RED oportunizam a aprendizagem e a interação e vinculação à escola a partir dos interesses dos alunos, são ricos em oportunidades e respeitam a diversidade de habilidades e potencialidades dos alunos. (Indv_372)

Para oferecer outras oportunidades de aprendizagem aos meus alunos, seja por meio de vídeos, atividades interativas ou o uso de simuladores (Indv_81)

Porque acredito que é uma forma de atingir todos os alunos, independente de seu grau de dificuldade. Os alunos se interessam mais por atividades digitais (Indv_329) 
Entendemos que os professores reconhecem que os recursos ampliam a experiência de aprendizagem dos alunos. Além disso, percebe-se que os professores atribuem ao RED uma característica inclusiva, pois revelam que eles são também utilizados para desenvolver a aprendizagem dos alunos que apresentam graus de dificuldades com algum conteúdo específico ou que possuem necessidades educativas especiais.

Integra-se também a esta subcategoria o uso dos RED para a "facilitação da aprendizagem". De acordo com os professores, os recursos são incorporados em sua prática pedagógica por acreditarem que contribuem para que os alunos alcancem os objetivos educacionais, e por facilitarem o seu processo de aprendizagem. Contudo, não percebemos em seus relatos elementos concretos que explicitem como ocorre essa facilitação da aprendizagem por meio dos RED.

Por acreditar que podem auxiliar no planejamento docente e no processo ensino/aprendizagem dos alunos. (Indv_205)

Para atingir melhor os resultados esperados para a aprendizagem dos educandos. (Indv_166)

Porque auxiliam no processo de ensino aprendizagem e tornam a aprendizagem muito mais significativa (Indv_138)

Para facilitar o ensino aprendizagem e colaborar com ambiente dinâmico (Indv_151)

Por que promovem uma aprendizagem mais participativa por parte dos alunos, levando-os a um aprendizado de qualidade (Indv_445)

Porque acredito ser uma ótima ferramenta de aprendizagem, possibilitando inúmeras possibilidades de recursos que tornam as aulas mais dinâmicas e interessantes, facilitando a aprendizagem. (Indv_359)

Porque acredito que ele nos oferece diversos recursos que facilita a aprendizagem do aluno, além de ser mais atraente para eles e com isso resultando em uma maior eficácia do ensino aprendizagem (Indv_252)

Porque além de facilitar a prática pedagógica em sala de aula, possibilita aos alunos uma aprendizagem mais dinâmica, prazerosa de didática (Indv_7)

Verificamos nessa subcategoria que os RED são utilizados principalmente com o objetivo específico de melhorar o processo de aprendizagem do aluno e o 
processo de ensino do professor. São achados desta subcategoria que na percepção dos professores, os RED são utilizados porque (i) contribuem para o aumento do interesse do aluno para a aprendizagem, (ii) promovem novas oportunidades de experiência de aprendizagem para os alunos, e (iii) são concebidos como facilitadores para melhorar a aprendizagem e para o alcance dos objetivos educacionais propostos. Contudo, não fica claro nos resultados quais elementos determinam o interesse dos alunos e como os RED podem facilitar os processos de aprendizagem. Sendo questões que precisam ser exploradas nas entrevistas.

\section{Suporte aos conteúdos}

$\mathrm{Na}$ subcategoria "suporte aos conteúdos" vemos que as práticas educacionais com os RED também estão ligadas com a aprendizagem de conteúdos específicos. Nessa abordagem o RED tem um papel mais instrucional e instrumental, pois é utilizado com caráter de "ilustração" de um conteúdo, correspondendo muitas vezes a uma abordagem tradicional do ensino com a tecnologia. Percebe-se em suas falas que os professores utilizam os RED para a "fixação" e "transmissão" de conteúdos sem que isso necessariamente se traduza em abordagem metodológica diferente, ou na reflexão no papel das tecnologias no processo de aprendizagem. Em ambos os aspectos, os RED são vistos mais como uma ferramenta que auxilia na exposição de conteúdos, como pode ser observado nos trechos a seguir.

Quando desejo que o meu aluno tenha mais informações e visualizações sobre um tema mais complexo ( $\left.\operatorname{Indv}_{2} 231\right)$.

Para ilustrar e contextualizar o conteúdo trabalhado em sala de aula. (Indv_277)

Como instrumento para a transmissão dos conteúdos (Indv_290)

Porque é uma ferramenta que auxilia o trabalho do professor na transmissão de vídeos e imagens que enriquecem os conteúdos transmitidos pelos professores (Indv_315)

Porque ajudam na recepção do conteúdo, fixando as imagens, os vídeos pedagógicos muito mais que os planos de aula tradicionais e estaticamente cansativos (Indv_169)

em alguns momentos pela praticidade, por proporcionar meios para representar modelos em 3D ou facilitar a compreensão da 
temática pelo uso de imagens (Indv_78)

$\mathrm{Na}$ maior parte das vezes, dinamiza a aula e consiste num recurso que os alunos se interessam mais para complementar os métodos tradicionais. (Indv_144)

Racionalização do processo de ensino

Também associado ao uso do recurso como suporte ao conteúdo encontramos elementos que demonstram que muitas vezes os professores utilizam os RED como forma de otimizar a dinâmica da sala de aula, seja com relação ao tempo, por maior praticidade e organização do trabalho pedagógico, maior alcance dos alunos ou agilidade das aulas no planejamento ou desenvolvimento das aulas. De acordo com as motivações dos professores, os recursos são utilizados sob as seguintes óticas:

Facilitar o trabalho e deixar a aula atrativa (Indv_192)

Para valorizar meu tempo e tentar facilitar a vida de alunos com necessidades educacionais especiais, principalmente aqueles que têm a parte motora afetada (Indv_34)

Porque as aulas tornam-se mais interessantes e otimiza o tempo (Indv_11)

Para facilitar/agilizar os meus trabalhos (Indv_279)

Agilidade e Desempenho (Indv_447)

Para atingir um maior número de alunos e focar mais na orientação da produção dos mesmos (Indv_221)

Minha disciplina são as Artes, o ambiente virtual oferece uma infinidade de opções de obras, propriamenteditas, para apresentar aos alunos, bem como para ampliar seus repertórios pessoais. Além disso, me permite agilidade na preparação das aulas, uma vez que via sites de pesquisa tenho muitas opções (Indv_356)

O RED é um facilitador metodológico para dar aulas; tenho multiplos formatos que levam o aluno a aprendizagem; facilita a elaboração dos planos de aula; é uma prática atrativa para o aluno; as aulas tornam-se dinâmicas; A multi opções de pesquisa para os alunos (Indv_437)

Reduzir Tempo, atrativo para alunos (Indv_98)

São recursos que facilitam a organização de todo material e 
gratificam visualmente (Indv_125)

Porque facilita meu trabalho e ganho tempo para uma melhor avaliação, seja ela, diagnóstica ou pedagógica para um melhor encaminhamento para e no ensino aprendizagem do aluno (Indv_87)

Percebemos na fala dos docentes que os RED são mais uma vez compreendidos como uma ferramenta tecnológica que dá apoio à atividade pedagógica do professor. Palavras-chave dessa subcategoria como "facilitar", "reduzir" e "agilizar" nos possibilitam interpretar que o uso dos recursos educacionais, para além de serem pensados para os objetivos fins educacionais (aprendizagem), são também percebidos como uma ferramenta que contribui para uma dinâmica mais racionalizada do fazer educativo em sala de aula.

Na figura 12 é possível visualizarmos os principais resultados da categoria "aprendizagem".

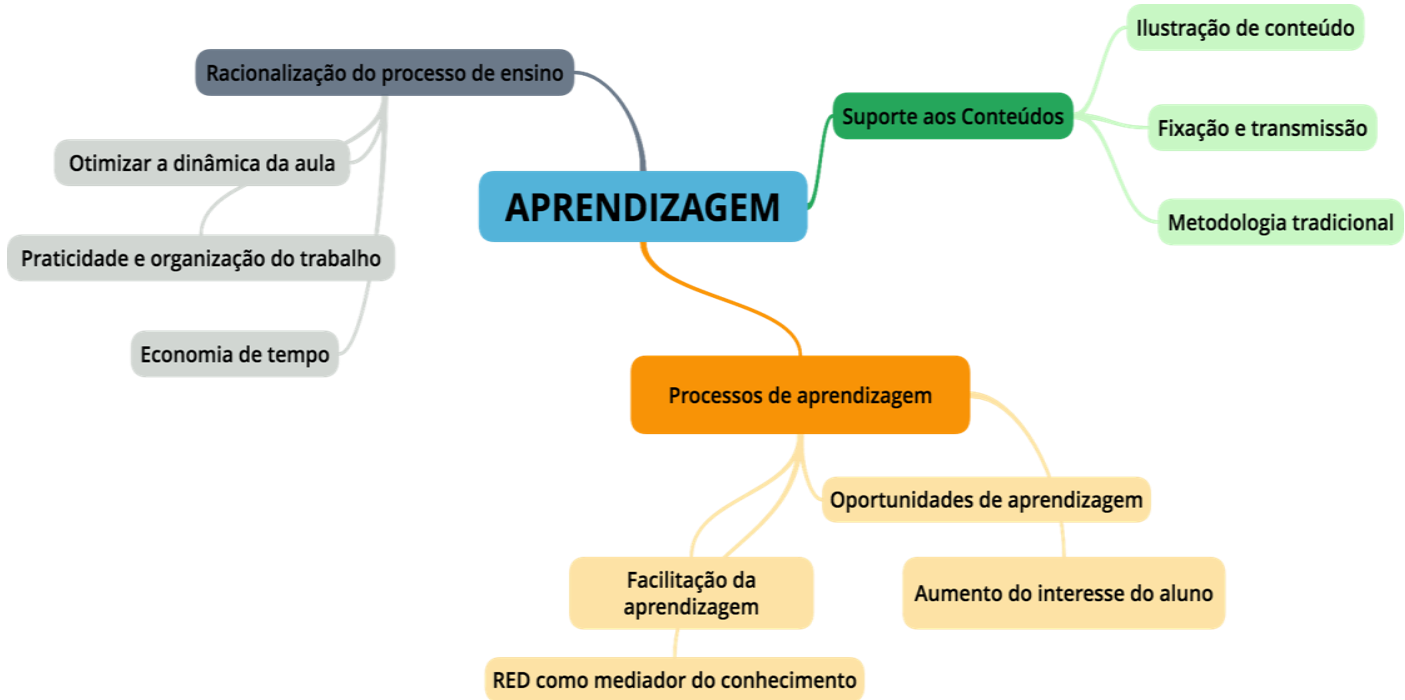

Figura 12 - Resultados da categoria aprendizagem. Fonte: Elaboração própria.

Analisando as falas que compõem esta categoria é possível compreender que existe um discurso otimista sobre o papel e a relevância que os RED ocupam no processo de ensino e aprendizagem. Esse otimismo aparece tanto na concepção do RED, como em um artefato que colabora para experiências mais significativas da aprendizagem, assim como para uma visão mais instrumental ou tecnicista desta tecnologia. Discutindo sob uma ótica mais crítica, especificamente sobre os objetos de aprendizagem, Barreto (2019) aponta que por trás da promoção destes recursos 
educacionais podem estar implícitos diferentes formas de substituição tecnológica. A autora considera que esta substituição não é do professor, mas sim uma expropriação do trabalho docente, visto que o professor, se não tiver clareza do papel dos RED e de outras tecnologias no seu planejamento pedagógico e no seu fazer em sala de aula, pode ocupar um papel de quem executa tarefas específicas relacionadas à docência. Como parece ser demonstrado nas falas dos professores que compuseram as subcategorias "suporte aos conteúdos" e "racionalização do ensino".

Neste sentido, carece-nos na análise desta categoria elementos que nos permitam aprofundar o entendimento de como os RED são utilizados pelos professores para ampliar e melhorar a experiência do aluno com a aprendizagem. De acordo com Selwyn (2017, p. 95),

É, portanto, essencial reconhecer que artefatos nem sempre mudam as coisas na educação para o melhor. As tecnologias nem sempre permitem que as pessoas trabalhem mais eficiente, como nem sempre ajudam as pessoas a fazer o que querem. Pelo contrário: as tecnologias podem, frequentemente, ter consequências inesperadas e indesejadas, ligadas a outras questões que ultrapassam as preocupações imediatas do ensino e da aprendizagem.

Como apontado por Pischetola e Miranda (2019), a tecnologia como elemento motivador ou facilitador na sala de aula pode esconder, na verdade, a insegurança do professor quanto às mudanças e à inadequação de suas práticas pedagógicas em competição com as tecnologias. Assim, é preciso considerar que as falas dos docentes que apontam uma visão mais generalista sobre os ganhos do uso do RED na educação podem demandar por uma visão mais profunda sobre os tipos de usos e os tipos de ganhos no processo de ensino e de aprendizagem, que perpassa pelas crenças, experiências, cultura e formação do professor. 


\section{2 .2}

\section{Desenvolvimento profissional docente}

A categoria "desenvolvimento profissional docente" compreende como os RED podem contribuir para o desenvolvimento do professor e de suas atividades pedagógicas. Como discutido no capítulo 2, o desenvolvimento profissional faz parte da identidade docente, sendo constituído a partir das experiências profissionais do professor, seu contexto profissional e seu engajamento, assim como a articulação de novos conhecimentos em sua prática docente e a inclusão de novas metodologias em seu repertório pedagógico (MOCKLER, 2011; MAIA, 2017).

Assim, o uso dos RED pode motivar o professor para a reflexão e inovação de sua prática pedagógica, como o desenvolvimento de competências digitais que possibilitam mudança da prática.

\section{Alteração da prática de ensino}

Nesta subcategoria verificamos que os professores utilizam os RED por acreditarem que estes contribuem para a mudança de práticas educacionais. As falas abaixo parecem indicar uma associação entre o uso das TIC com a alteração da prática pedagógica e estratégias metodológicas, existindo uma ênfase na responsabilidade do professor no desenvolvimento destas mudanças.

Outro ponto é a crença ou a percepção de que a alteração da prática educacional com o RED se reflete no aumento do interesse do aluno em relação à disciplina. Percebe-se que o docente se assume como agente de mudança em seu contexto profissional, pois se enxerga como protagonista na alteração de sua prática de ensino.

Porque sinto necessidade de utilizar novas metodologias de ensino e os recursos educacionais digitais me permitem isso, um novo modo de ensinar (Indv_233)

Para diversificar e agregar novas práticas pedagógicas em meu trabalho de ensinar, para facilitar a aprendizagem do(a) aluno(a) (Indv_253)

Porque é um aliado na aprendizagem do meu aluno, tornando a prática mais significativas e com novas metodologias de estudo 
consigo atingir a todos os alunos, inclusive os que apresentam dificuldade de aprendizagem ou transtornos (Indv_401)

Acredito que nos auxiliam em novas metodologias para ensinar oportunizando experiências e aprendizados significativos para os adolescentes (Indv_461)

Para as aulas ficarem mais atrativas e também formas diferentes de trabalhar os conteúdos com novas abordagens para que saia do tradicional ( Indv_218)

Acredito que os Reds podem contribuir diretamente para uma melhora na prática docente e pode sim ser um agente motivador para os alunos, mas não podemos esquecer que o uso dos mesmos não substituem uma boa prática docente! (...) (Indv_432)

Para melhorar minhas práticas pedagógicas e oportunizar uma aprendizagem mais significativa aos meus alunos, também para que os mesmos sintam-se valorizados (Indv_88)

É uma forma de diversificar as aulas e torna-las mais interessante do ponto de vista da juventude atual que tem um interesse muito focado nas tecnologias digitais (Indv_20)

Quando possível e a estrutura permite é uma maneira de incrementar as aulas e promover metodologias diferenciadas (Indv_73)

Segundo Pischetola e Miranda (2019), o discurso da alteração pedagógica, representado pelo slogan da "inovação" pode estar atrelado à noção de que o novo é sempre melhor que o antigo. As falas dos professores mostram um retrato do RED como um elemento transformador na sala de aula, como se a sua presença já aumentasse a motivação do aluno para a aprendizagem, o que pode indicar um esvaziamento de uma compreensão mais crítica sobre o papel da tecnologia no processo de ensino, considerando que os docentes não trazem elementos paupáveis de como a utilização do RED altera a prática educacional, segundo a sua experiência.

Por outro lado, o reconhecimento de que a utilização dos RED tem um impacto positivo na dinâmica da sala de aula pode indicar que o professor enxerga no uso da tecnologia uma forma de buscar crescimento profissional, no sentido de procurar outras formas de despertar o interesse do aluno. Assim, o discurso do professor parece indicar um certo grau de compromisso com a sua função social como mediador da aprendizagem, pois revê, renova e desenvolve seu compromisso 
como agente de mudança, transformando sua realidade (DAY, 2003).

Ainda que, em suas falas, o professor aparente carregar o peso como o profissional responsável pelo fator transformador do uso da tecnologia em sala de aula, entendemos que a mudança da prática pedagógica na educação não depende de um sujeito único, pois como aponta Pichetola e Miranda (2019, p. 21):
Ao falarmos da integração cultural das TIC na educação, precisamos entender que gestão escolar, conexão de Internet, equipamentos, professores, alunos, pais, espaços físicos, práticas pedagógicas, infraestrutura, relações, habilidades, conhecimentos, conteúdos, métodos, técnicas e instrumentos constituem as partes de um sistema aberto, ativo e complexo.

Nesse sentido, entendemos que a integração significativa das TIC na educação não depende exclusivamente do professor, mas precisa contar com todo um complexo de agentes, de forma a criar uma imersão de práticas culturais com as TIC, resultando assim, em mudanças na prática educacional do professor.

Embora nos faltem elementos para compreender como o emprego dos RED no processo de ensino poderia alterar a prática pedagógica, verifica-se que a associação do uso dos RED com a elaboração de aulas, capazes de desenvolver o interesse dos alunos por ser mais atrativa, dialoga com a importância que os professores dão para a diversificação da metodologia em sala de aula. Para Maia (2017), a criação ou a diversificação da metodologia empregada na prática de ensino indica a articulação de novos conhecimentos na prática pedagógica do professor, pois se compreende que, ao buscar diversificar ou inovar em sua prática, o professor precisa refletir sobre sua ação e sistematizar novos conhecimentos (pedagógicos e tecnológicos). Assim, são resultados do investimento do professor em seu desenvolvimento profissional, produzindo mudanças em sua realidade profissional.

Verifica-se que o desafio de integrar os RED no cotidiano da sala de aula promove um "repensar" da metodologia impulsionando o docente ao movimento de se desenvolver profissionalmente, no sentido de procurar novas metodologias que se adequem ao uso do RED.

Contudo, essa alteração da metodologia empregada a partir das TIC ainda é 
percebido como algo isolado que depende apenas do professor. Nesse sentido, verifica-se que os professores defendem que existe uma relação entre o uso do RED com o desenvolvimento de aulas mais atrativas e o aumento do interesse do aluno pela aprendizagem, mas essa percepção ainda carece de elementos mais críticos que permitam ao docente relativizar essas relações, e principalmente que possibilite que o professor não se veja como o único responsável pela alteração da prática pedagógica com RED.

\section{Desenvolvimento de competências pedagógicas digitais}

Nesta subcategoria entende-se que, ao incorporar as tecnologias digitais em sua atividade profissional, os professores conseguem construir competências pedagógicas significativas para seu fazer educativo. Reforçando os achados dos dados quantitativos, percebe-se que a principal competência construída pelos docentes com os usos dos RED é o planejamento pedagógico.

Acreditamos que tais resultados se relacionam com os tipos de competências digitais construídas pelos professores, que, por parecer estar em níveis mais iniciais de domínio tecnológico, como interpretado no gráfico 6A (pag. 107), têm as competências digitais mais frequentemente integradas às atividades de planejamento de ensino. Por outro lado, percebemos que em algumas falas os professores acreditam que a utilização de RED colabora para o aumento do conhecimento com a tecnologia para o desenvolvimento de pesquisa e da formação contínua.

Para fomentar o plano de aula e para melhorar as minhas práticas docentes (Indv_248)

Me ajuda muito planejamento diário (Indv_260)

Para preparar minhas aulas, pesquisar atividades, ensinar os alunos, para as redes sociais, para trabalhar e assistir também (Indv_332)

Utilizo no meu planejamento diário e em busca de aperfeiçoamento profissional. Realizo cursos através de plataformas on-line ( $\operatorname{Indv}_{-} 335$ )

Para a elaboração de aulas mais atrativas (Indv_402) 
Para aprimorar e melhor elaborar minhas aulas, tornando-as mais atrativas e acompanhando o desenvolvimento tecnológico (Indv_452)

Nossos alunos estão integrados em uma geração digital, então porque não unir o útil ao agradável? Melhora nossos conhecimentos com a tecnologia, principalmente professores que como eu não tinham essa praticidade em sua formação, a riqueza de conteúdos, pesquisas e formas de aprendizagem tanto para o aluno como para o professor nos mostra um leque de opções, favoráveis e até desfavoráveis onde o filtro de cada profissional fará a diferença (Indv_339)

Compreender e utilizar as mais variadas tecnologias são competências que todos nós devemos desenvolver atualmente, enquanto educadores e cidadãos. A tecnologia me atrai pessoalmente, tenho facilidade na absorção de conhecimentos nesse sentido e acredito que a Escola deve ser um espaço de exploração, desenvolvimento, pesquisa, formação e construçao de conhecimento (Indv_367).

$\mathrm{Na}$ figura 13 podemos observar os principais pontos que abarcaram a categoria "desenvolvimento profissional docente".

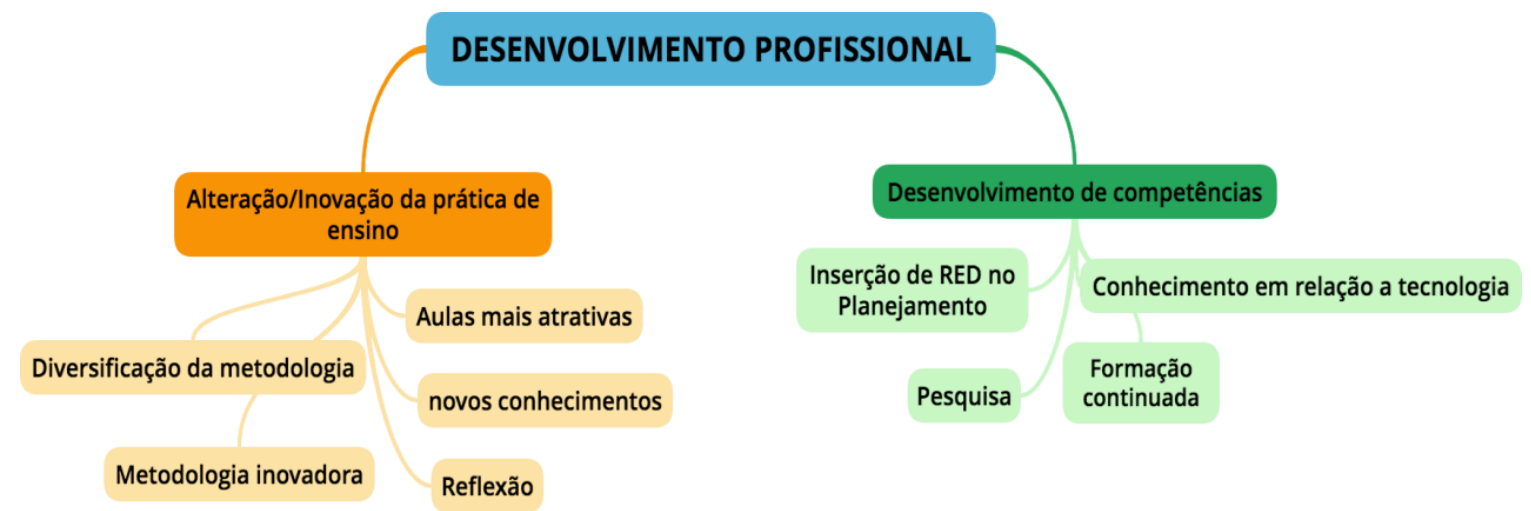

Figura 13 - Resultados da categoria "desenvolvimento profissional docente”. Fonte: Elaboração própria.

Pesquisas sobre o desenvolvimento de competências digitais com e a partir dos usos dos RED indicam que pode existir uma correlação entre a valorização de processos metodológicos mais inovadores e a valorização do uso de RED (MIRALLES-MARTÍNEZ et al., 2019) e, no caso de docentes em formação continuada, verificou-se que a utilização de RED desenhados pelos próprios 
estudantes melhoraram a sua competência digital em relação às buscas de informação on-line, seleção eficaz de recursos, navegação entre os RED e criação de estratégias pessoais para a seleção de informações (VELAZQUEZ-CANO; MARTÍN-MONJE; LARRETA-AZELAIN, 2016).

Olhando para os resultados desta subcategoria e comparando com os resultados de pesquisas anteriores, compreendemos que existe a tendência da utilização de RED contribuir para o desenvolvimento de competências digitais mais ligadas à literacia da informação e ao planejamento didático (SILVA, LOUREIRO, PISCHETOLA, 2019).

\section{2 .3}

Inserção na Cultura Digital

A categoria "inserção na cultura digital" responde aos professores que afirmam utilizar os RED por acreditarem que eles são próximos da linguagem do aluno que já utiliza as tecnologias em ambientes fora da escola. Assim, na percepção destes, o aluno já imerso na cultura digital perceberia as aulas que utilizam os RED com mais interesse, como já fora apontado na categoria aprendizagem. Também se incorpora à essa categoria os professores que usam os RED por terem a crença de que a escola está inserida no contexto e na cultura em que as tecnologias são utilizadas amplamente e, por isso, precisam se conscientizar da importância de utilizar as tecnologias no cotidiano escolar. Pischetola (2016) entende este movimento como "discurso de inevitabilidade", ou seja, os professores reconhecem que a tecnologia faz parte da sociedade e a escola precisa mudar e se adequar a isso, fazendo a mediação entre o aluno e as tecnologias.

Na subcategoria "escola inserida na cultura digital" verificamos nas falas dos professores que eles acreditam que a tecnologia já faz parte da sociedade e da escola e que é papel do professor integrá-las na sala de aula. Como pode ser observado nas seguintes declarações:

Por que nosso mundo é isso. Não dá pra trabalhar em sala de aula nos dias atuais sem pensar no uso das tecnologias. Ganhamos tempo, aulas mais dinâmicas e interativas etc 
(Indv_245)

Por que vivemos na era digital, e a cada dia é preciso estar familiarizado com as novas tecnologias. Elas devem servir para o desenvolvimento de uma sociedade mais humana (Indv_106)

Porque acredito que a educação deve caminhar com a sociedade e suas dimensões (Indv_351)

Na era da Inclusão Digital em que vivemos é impossível não usar os RED, ainda mais na área em que atuo -informática (Indv_469)

Porque estamos vivendo um tempo em que as tecnologias estão em evidência e não tem como não usá-las (Indv_191)

No mundo digital contemporâneo não podemos abrir mão dos Recursos digitais, que ajudam a tornar as aulas mais atrativas e de melhor assimilação (Indv_29)

Porque acredito que a educação deve caminhar com a sociedade e suas dimensões (Indv_351)

Utilizo porque são recursos ótimos e atuais e prendem a atenção dos alunos. No mundo contemporâneo é imprescindível que utilizemos as RED na prática pedagógica, pois no mundo digital em que vivemos tudo acontece muito rápido e temos que acompanhar o ritmo de nossos educandos que estão conectados o tempo todo (Indv_391)

Nesta subcategoria o discurso dos professores parece corresponder à lógica determinística da tecnologia. Sewyn (2017), ao apontar questionamentos críticos sobre a tecnologia e a educação e se baseando em Postman, explica que ao pensarmos nos indivíduos e nas instituições que constituem a "educação", precisamos olhar para além da tecnologia, focando nosso olhar nos contextos sociais de seus usos, e considerando a educação e a tecnologia como experiência humana.

Assim, embora a escola seja, de fato, parte de uma sociedade que está permeada pelas tecnologias, precisamos considerar que o diálogo entre escola, sociedade e tecnologias perpassa pelo tipo de experiência que cada ator possui com cada um destes pilares. É claro que reconhecer a existência de uma relação entre sociedade, tecnologia e escola é um começo para se refletir nos tipos de experiências construídas até então, e nos tipos de experiências e aprendizagens que se quer construir no futuro, mas isso não pode ser encarado como um movimento natural, evolutivo ou determinístico da relação sociedade e escola. 
Já na subcategoria "aluno inserido na cultura digital" percebe-se que os professores utilizam os RED por acreditarem que os alunos se sentem mais motivados com o uso de artefatos tecnológicos porque estão imersos em um ambiente cultural em que já se constroem práticas diversas com as tecnologias. Observando as falas dos professores, percebemos uma tendência para um discurso de representação do aluno como alguém naturalmente "fluente" no uso da tecnologia, como mostram os elementos a seguir.

Porque nossos alunos hoje são digitais (Indv_336)

Porque hoje é essencial inserir as tecnologias na escola, os alunos são digitalizados, porém as escolas não possuem recursos que atendam a necessidade (Indv_237)

Nossos alunos estão integrados em uma geração digital, então porque não unir o útil ao agradável? Melhora nossos conhecimentos com a tecnologia, principalmente professores que como eu não tinham essa praticidade em sua formação, a riqueza de conteúdos, pesquisas e formas de aprendizagem tanto para o aluno como para o professor nos mostra um leque de opções, favoráveis e até desfavoráveis onde o filtro de cada profissional fará a diferença (Indv_339)

É preciso estar constantemente se atualizando para acompanhar a realidade dos alunos que já nascem em sociedade virtual, entender suas linguagens e comportamentos (Indv_236)

Nessa Nova Geração, o uso passa a ser fundamental dentro da sala de aula e em outros setores da escola. (Indv_267)

Porque meus alunos são nativos digitais e entendem melhor os conteúdos quando utilizo recursos digitais (Indv_153)

Nos dias de hoje temos muitas ferramentas digitais ou de Tecnologias modernas que facilitam o aprendizado do aluno que nasceu na Era Tecnológica, então por que não atraí-los com o que ele mais gostam. (Indv_449)

Essa representação de um aluno "nativo digital" (PRENSKY, 2001) fortalece uma visão acrítica do papel do professor ao mediar o uso das tecnologias pelos alunos, desenvolvendo competências e habilidades digitais. Constatar que o aluno faz parte de uma sociedade em que a tecnologia está integrada, ou que ele faz uso intenso da tecnologia não se traduz em interesse por aprender com o uso da tecnologia e no desenvolvimento de competências e habilidades para os usos sociais das TIC. De acordo com Pischetola e Heinsfeld (2018), é necessário a mediação do 
professor para que o aluno alcance a "fluência tecnológica". Para as autoras, com respeito à escola "é preciso reformular o lugar do professor, a sua prática pedagógica e a relação que ele constrói com os alunos, convidando-o a tornar-se mais conscientes das mudanças em curso" (p. 8). Contudo, os depoimentos dos docentes parecem indicar que eles veem no contato e interesse que os alunos têm com a tecnologia uma porta de acesso para a construção de uma aprendizagem mais significativa ao integrar os RED em sua prática educacional.

É uma forma de diversificar as aulas e torna-las mais interessante do ponto de vista da juventude atual que tem um interesse muito focado nas tecnologias digitais (Indv_20)

Porque são recursos que permitem alcançar a realidade do aluno, pois eles estão chegando a escola com noções de tecnologia desde a infância. É necessário acompanharmos a evolução tecnológica e utilizá-la a nosso favor no cotidiano escolar (Indv_31)

Sempre busquei maneiras de atingir os alunos e, como eles amam as tecnologias, foi uma das formas que mais deu resultado na minha prática. Contudo, é preciso tomar alguns cuidados, pois do contrário, torna-se mais do mesmo e os alunos deixam de se interessar. A diversificação das ferramentas deve ser intensificada, a meu ver (Indv_136)

Nossos alunos estão integrados em uma geração digital, então porque não unir o útil ao agradável? Melhora nossos conhecimentos com a tecnologia, principalmente professores que como eu não tinham essa praticidade em sua formação, a riqueza de conteúdos, pesquisas e formas de aprendizagem tanto para o aluno como para o professor nos mostra um leque de opções, favoráveis e até desfavoráveis onde o filtro de cada profissional fará a diferença ( $\left.\operatorname{Indv} \_339\right)$

Nesse sentido, percebemos que os professores têm a visão de que as tecnologias já estão presentes na sociedade e na escola, e por isso, se torna inevitável o trabalho pedagógico com elas em sala de aula. Outro aspecto é a percepção de que pelo aluno estar imerso na cultura digital naturalmente irá desenvolver interesse por aprender com as tecnologias, indo na contramão de 
pesquisas que apontam que a visão do jovem "nativo digital" é determinística, e que é necessário a mediação docente para que ocorra aprendizagem com o uso da tecnologia (PISCHETOLA, HEINSFELD, 2018; BUCKINGHAM, 2010). A figura 14 nos permite compreender melhor como tais resultados estão presentes na categoria "inserção na cultura digital".

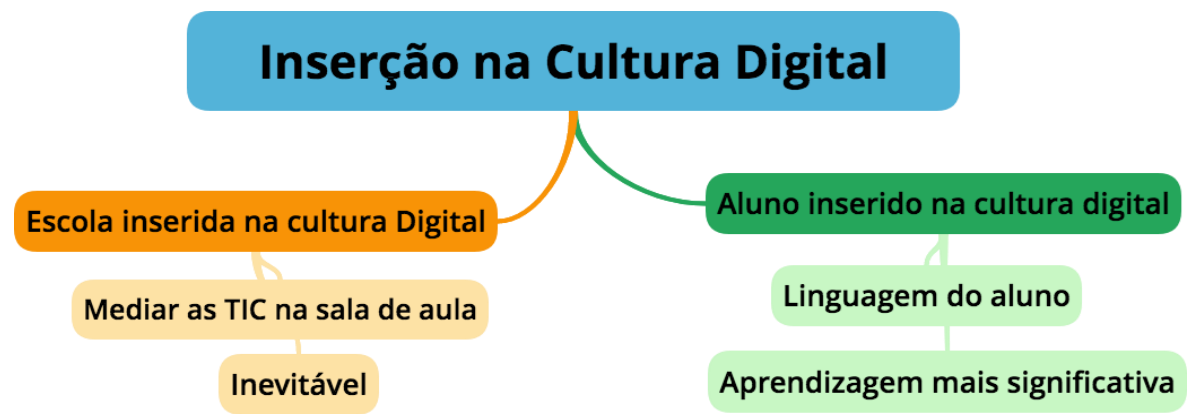

Figura 14 - Resultados da categoria “inserção na cultura digital”. Fonte: Elaboração própria.

Voltando para a ideia de "inevitabilidade tecnológica", os resultados encontrados na categoria "inserção na Cultura Digital” parecem indicar que, na visão do professor, os RED e outras tecnologias na escola é um caminho sem volta que conversa com um desenrolar evolutivo da sociedade.

\section{3}

\section{Análise de conteúdo das entrevistas}

Para a coleta dos dados provenientes da entrevista, contou-se com a participação de 6 professores. Como abordado no capítulo metodológico, foram selecionados e convidados 15 docentes para participarem da entrevista.

O convite foi realizado por meio do email disponibilizado pelos participantes ao responderem o questionário inicial, sendo que 8 pessoas responderam ao contato demostrando interesse e 6 pessoas, efetivamente, participaram da entrevista. Na tabela 6 podemos verificar as características ou descritores que foram utilizados na análise de conteúdo. 


\begin{tabular}{|c|c|c|c|c|}
\hline Nome Fictício & $\begin{array}{l}\text { Tempo de } \\
\text { Docência }\end{array}$ & $\begin{array}{c}\text { Campo do } \\
\text { Saber }\end{array}$ & Titulação & $\begin{array}{l}\text { Segmento de } \\
\text { atuação }\end{array}$ \\
\hline Diamante & $\begin{array}{l}\text { Mais de dez } \\
\text { anos }\end{array}$ & Linguagens & Mestrado & Ensino Médio \\
\hline Esmeralda & $\begin{array}{l}\text { Mais de dez } \\
\text { anos }\end{array}$ & $\begin{array}{l}\text { Ciências } \\
\text { Humanas }\end{array}$ & Especialização & Ensino Médio \\
\hline Citrino & $\begin{array}{l}\text { Mais de dez } \\
\text { anos }\end{array}$ & $\begin{array}{l}\text { Ciências } \\
\text { Natureza }\end{array}$ & Especialização & Ensino Médio \\
\hline Jade & $\begin{array}{l}\text { Mais de dez } \\
\text { anos }\end{array}$ & $\begin{array}{l}\text { Ciências } \\
\text { Humanas }\end{array}$ & Especialização & Ensino Médio \\
\hline Ametista & $\begin{array}{l}\text { Mais de dez } \\
\text { anos }\end{array}$ & $\begin{array}{l}\text { Ciências } \\
\text { Humanas }\end{array}$ & Especialização & Ensino Médio \\
\hline Opala & $\begin{array}{l}\text { Mais de dez } \\
\text { anos }\end{array}$ & $\begin{array}{l}\text { Ciências } \\
\text { Natureza }\end{array}$ & Doutorado & Ensino Médio \\
\hline
\end{tabular}

Tabela 6- Descritores para análise da entrevista. Fonte: Elaboração própria

Para análise de conteúdo dos dados da entrevista adotamos um sistema de categorias aberto (AMADO, 2013; GLASER e STRAUSS, 1967), ou seja, induzido a partir da análise do investigador juntamente com seu background teórico. Como apresentado no quadro 1 (pág. 74), tencionávamos a partir das entrevistas compreender como os RED são utilizados por professores nos seus contextos profissionais, se tinha e qual era a sua contribuição para o desenvolvimento de práticas autorais dos docentes, e quais eram as principais motivações para que os RED fossem utilizados. Com tais objetivos traçados e através da leitura exaustiva dos dados foram mapeadas três categorias de análise, a saber: i) concepções sobre autoria, ii) percursos para autoria docente e iii) relação da autoria docente com as tecnologias.

No quadro 9 verifica-se a distribuição das referências ou unidades de registro entre as categorias. Podemos observar que as categorias "concepções sobre a autoria" e "relações da autoria docente com a tecnologia" tiveram uma representatividade semelhante na análise com 49 e 50 referências respectivamente. 


\begin{tabular}{|c|c|c|}
\hline Categorias & Subcategorias & Referências \\
\hline \multirow{3}{*}{$\begin{array}{l}\text { Concepções sobre } \\
\text { Autoria }\end{array}$} & Definições de autoria & 12 \\
\hline & Práticas autorais na docência & 26 \\
\hline & Influência da Autoria docente & 11 \\
\hline \multicolumn{2}{|c|}{ Percurso para a autoria docente } & 21 \\
\hline \multirow{3}{*}{$\begin{array}{llr}\text { Relações da autoria } & \text { a } \\
\text { docente } & \text { com } & \text { a } \\
\text { tecnologia } & & \end{array}$} & Uso de RED e outras tecnologias & 23 \\
\hline & Criação de RED & 14 \\
\hline & Competências digitais & 13 \\
\hline
\end{tabular}

Quadro 9 - Referências por categoria na análise das entrevistas. Fonte: WebQDA

$\mathrm{Na}$ figura 15 visualizamos as palavras mais citadas pelos entrevistados. As palavras de maior relevância na fala dos docentes foram "autoria", "professor", "fazer", "alunos", “formação" e "tecnologia”, podendo assinalar que as práticas autorais do professor perpassam e são influenciadas por todas essas palavras-chave.

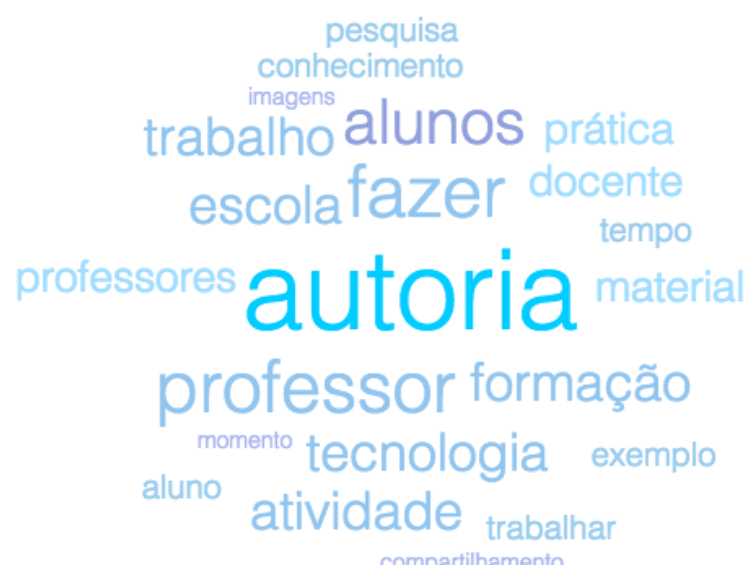

Figura 15 - Nuvem de palavras - entrevistas. Fonte: WebQDA

A seguir, apresentamos os resultados da análise de conteúdo da entrevista conforme as categorias expostas no quadro 9. 


\subsection{1}

\section{Concepções sobre autoria}

A categoria "concepções sobre autoria" tenta compreender a visão dos docentes entrevistados sobre o que é autoria, seu reconhecimento ou não como autor e como esse conceito está presente ou não na sua prática pedagógica. Nossa intenção foi mapear indícios do que é a autoria docente e como ela se manifesta e se constrói a partir do cotidiano do professor. A categoria representou $41 \%$ das referências e foi dividida em três subcategorias: i) definições de autoria, ii) práticas autorais, e iii) influência da autoria docente. A seguir, apresentamos os resultados de cada subcategoria, indicando suas interpretações e contribuições para o estudo.

\section{Definições de autoria}

A subcategoria "definições de autoria" aborda as concepções que os professores entrevistados têm sobre o conceito de autoria. Percebemos em nossa revisão de literatura que este conceito é interpretado por diferentes óticas e é recorrente em diversos campos do conhecimento. Sendo assim, essa subcategoria se propõe a explicitar o que é a autoria na ótica daquele que está em sala de aula.

Percebe-se nas falas dos docentes o entendimento que a autoria não se relaciona apenas com a criação original, como é uma ideia amplamente propagada pelo senso comum. Ainda que esteja presente na fala dos professores a noção da originalidade, existe um consenso que ela acontece a partir de uma construção histórica, releituras e pontos de partidas. Esse conceito de autoria foi compartilhado por todos os professores entrevistados, podendo indicar uma visão de autoria mais crítica. Vejamos como a percepção destes docentes sobre esse conceito se manifesta:

Eu penso que autoria é você criar algo seu, próprio. Nem sempre muito inédito. Eu acho que nós somos resultados de construções durante a vida toda, né?! Algumas pessoas são capazes de serem inéditas, eu não sou inédita não. Quando eu vejo, eu me reproduzo, me repito e repito de formas diferentes aquilo que eu já vi de outra forma dito, né?! Eu acho que autoria vem a partir disso, de você 
criar ou recriar aquilo que já foi dito, exprimindo a visão que nem todos têm. Eu acho que autoria significa criar, significa construir algo não tão novo, mas com o olhar novo, talvez.

Ametista

Como uma proposta inédita. Uma ideia em que você desenvolveu a partir da análise de um objeto. Sei lá... que você propôs né?! A autoria está relacionada com a originalidade no sentido de produção né?! Você pode até fazer uma análise de algo que já está pronto, mas que ali tenha algo que você defende.

Diamante

Autoria seria algo próprio né?! Do indivíduo. Ele que cria a partir de uma inovação. É lógico que tem um ponto de partida, ele tem as ideias, ele tem as pré ideias pré-concebidas, mas a partir daí ele cria, tem autoria. É essa inovação que ele faz a partir de um ponto que é a autoria.

Jade

Então eu proponho uma atividade sobre Grécia antiga para os meus alunos, porém o meu ponto de partida não é uma criação minha. $\mathrm{O}$ meu ponto de partida é partir do que eu estudei, do que eu já li, das experiências que eu vivenciei. Então eu vou inovar, eu vou criar, eu vou fazer algo que é meu, que vai ter a minha individualidade, a minha subjetividade, porém eu não parto do zero e nem sou a criadora. Eu parto de algo que alguém já fez.

Jade

O conceito de autoria relacionado a algo inédito ou original está ligado a uma visão do autor como um gênio que recebe uma inspiração e que se traduz em um ato de criação. Essa ideia, de acordo com Martins (2012), ganha força com o Romantismo, onde a inspiração passa a ser fruto da interioridade do próprio escritor, que começa a ter a sua capacidade criativa mais valorizada. Quando os docentes trazem em suas falas a presença da originalidade na autoria, percebe-se que é uma originalidade diferente da que é propagada pelo Romantismo, pois apresenta a consciência de que o original ou o inédito é um ponto de avanço que parte de algo que já está criado. 
Nas falas em destaque, é evidente a posição que os docentes tomam da autoria como um processo em que se consideram fundamentais as leituras e experiências prévias desse autor. Essa ideia de autoria, que não mais traduz a pura genialidade do autor, conversa com a concepção de Barthes (2004) ao defender que "o Autor está morto".

Para Barthes, o discurso da originalidade é questionável, visto que um texto provém de múltiplas dimensões que, por sua vez, advém de diferentes focos de cultura. Nesse ponto de vista, o autor imita um gesto sempre anterior e nunca original, onde em uma analogia como um tecelão irá "mesclar as escrituras, em fazê-las contrariar-se umas pelas outras" (p. 62). Podemos perceber a visão do autor como alguém que tece conceitos, leituras prévias e vivência, nas seguintes passagens:

A partir de algo que já existe, mas que você faz uma adaptação para o seu uso em sala de aula, mas que você coloque ali dados, ou análises, ou a reprodução de uma aula, por exemplo. Mas que ali tenha alguma coisa que foi você que fez a adaptação e não uma cópia simplesmente de algo que viu ou leu...

... Puxa, também é autor quando ele amplia, adapta um material.

Diamante

É a criação própria a partir do conhecimento que você tem de algum assunto e aí você está expondo o seu trabalho, a sua autoria.

Citrino

O conceito de autoria é você formular em cima de vários outros conceitos ou vários outros conhecimentos, um conhecimento próprio...

Quando você tem um diálogo, você vai formar uma opinião e essa opinião você vai dialogar em cima daquilo que você tem como conceito, como autoria própria, né?! Daquilo que você convive, do ambiente, dos seus conceitos, e você formula em cima dos seus próprios conceitos. Então é isso que eu penso de autoria né?! É uma autoria minha em relação a determinado conhecimento. 
As considerações acima nos remetem à autoria como um processo aberto. Da mesma forma que a criação tem como ponto de partida as criações anteriores, ela não se fecha em si mesma depois de criada. A partir da análise das falas dos professores compreendemos que essa autoria tem uma função ou uma continuidade, ela pode ser assim entendida com um início de um agrupamento do discurso, ou seja, o professor autor assume o papel de um instaurador de discursividade (FOUCAULT, 2001), abrindo espaço para outras autorias posteriores, de outros professores ou através do trabalho com os alunos.

Observamos na fala dos professores que autoria se constrói a partir de vários nós, assim ela não tem uma origem única e é fortemente baseada no princípio de coletividade. Ainda que se defina autoria como uma criação individual, a coletividade está presente na construção histórica do conhecimento, que serve de base para uma nova criação.

Concebendo a autoria como uma criação individual ou coletiva, que tem como precursores a construção histórica e a bricolagem de conhecimentos de diferentes fontes culturais, é importante discutirmos como o entendimento que estes professores têm sobre autoria está presente ou não em sua prática pedagógica.

\section{Práticas autorais na docência}

A subcategoria "práticas autorais" compreende as práticas pedagógicas realizadas no cotidiano escolar, que são apontadas pelos docentes como autorais. Percebe-se que tais práticas se dividem em três grupos: (i) a autoria presente no planejamento do ensino; (ii) a autoria que se manifesta na forma que o professor lida com o "improviso" ou quando o que foi planejado não acontece em sala de aula; e (iii) as adaptações e ressignificações considerando o contexto da escola e dos alunos.

No primeiro grupo "autoria presente no planejamento do ensino", observamos que o professor reconhece a sua prática de planejar como o momento em que ele pensa no contexto de seu trabalho e cria com foco a atender às demandas dos alunos. Sabemos que o planejamento do ensino faz parte da atuação do professor e compreende o momento em que este reflete sobre sua ação, 
considerando os objetivos educacionais, os conteúdos, a metodologia e a avaliação. Também é durante a fase do planejamento que o professor pesquisa, seleciona ou cria e organiza recursos educacionais que serão trabalhados durante a aula. Segundo Lopes (1996), o planejamento do ensino é dirigido para uma ação pedagógica que é crítica e transformadora, e possibilita ao professor maior segurança para lidar com a relação educativa que ocorre na sala de aula e na escola. Podemos observar na fala dos docentes como a prática do planejamento de ensino é compreendida como um espaço autoral do professor.

Eu preparo uma aula bem planejada, mas aproveitando e considerando a realidade ou o contexto que eu tenho. É quando eu uso, vamos dizer assim, elementos que enriquecem a minha prática com os meus alunos. Então pode ser que, de repente, não seja uma ideia original, mas a proposta de trabalho, ela é original. Porque ali eu vou preparar algo condizente com a realidade que eu tenho.

Diamante

\begin{abstract}
No planejamento de aula, no meu plano de ensino. Porque assim, é aquela questão, nós temos os roteiros, nós temos o rol dos conteúdos, nós temos coisas que são impostas, que são diretrizes para o nosso trabalho. Mas a partir daquilo você cria, você faz mil coisas dali. Não é porque eu tenho que trabalhar com adição e subtração que eu vou encher o quadro com continhas.
\end{abstract}

Esmeralda

A partir da análise das falas dos professores, entendemos que a prática autoral que está presente no planejamento diz respeito à criação da atividade de ensino (proposta original a partir de uma ideia que não é original), em que o professor considera o contexto em que está inserido e a continuidade ou os desdobramentos que o docente dá aos conteúdos curriculares. Recuperando o conceito da função-autor como um instaurador de discursividade, compreendemos que os roteiros e guias curriculares assumem essa função, onde, a depender da construção autoral de cada professor, poderá se desdobrar em autorias durante o planejamento do ensino. Ao mesmo tempo, percebemos que também está implícita nessa prática autoral a noção da autoria como um ponto de inovação ao que é posto 
antes, oriundo de múltiplas dimensões (currículo oficial, ideias pré-concebidas, experiências, recursos prontos e etc).

De acordo com Morais e Pinho (2017), é importante que a criatividade esteja presente no planejamento do professor visando realizar diferentes estratégias para o desenvolvimento das atividades docentes, com foco no processo de ensino e aprendizagem. Também para Oliveira e Alencar (2014), o planejamento de estratégias de ensino foi identificado como uma das categorias de um professor considerado criativo, englobando neste aspecto a inovação, a busca de novas maneiras de ensinar, aulas mais dinâmicas, interligação de sua disciplina com outras, e o estímulo à participação e ao pensamento crítico e reflexivo do aluno.

Outra prática autoral que se relaciona com o planejamento é o entendimento de que o professor não pode ficar preso ao que foi planejado, ele precisa considerar que, ainda que a aula seja planejada, precisa existir um espaço para a criação durante o acontecer da aula, sendo essa também uma prática autoral. Nas falas dos docentes encontramos muitas vezes o termo "improviso" ou "saber lidar com o imprevisto" como uma prática autoral do professor. Consideramos este "saber lidar com o imprevisto" como um tipo de competência que se relaciona com a práxis da profissão docente, fazendo parte dos saberes da experiência (TARDIF, LESSSARD, LAHAYNE, 1991) da prática profissional do professor. Segundo Pinto (2001), o professor nem sempre encontra em seu ambiente de trabalho regras rígidas e materiais previamente detalhados, tendo que valer-se dos recursos disponíveis. Nesse sentido, criar e improvisar diante de situações que são imprevistas são também características da profissão docente. Tardif, Lessard e Lahayne (1991, p. 228) explicam como este improviso faz parte dos saberes da experiência do professor. Para os autores, "no exercício cotidiano de sua função os limites aparecem relacionados a situações concretas que não são passíveis de definições acabadas, e que exigem uma cota de improvisação". Vejamos como este improviso é reconhecido pelos professores como uma prática autoral:

Porque o conhecimento perpassa todas as disciplinas, todos os ambientes. Ela é a nossa vida. Então matemática, ela é a aula de matemática, mas surgiu uma pergunta de ciências, eu vou trabalhar porque surgiu. Então eu sempre trabalhei nessa perspectiva de não 
ficar ali presa ao planejamento, ao plano de aula. Vamos extrapolar? Vamos...

Esmeralda

Você tem que ter na manga várias dinâmicas para o mesmo conteúdo, independente das turmas que você entra. Você entra numa turma e funcionou direitinho, chega na outra e não funciona, você tem que mudar alguma coisa, alguma estratégia para ver se consegue atingir um objetivo melhor. Nem sempre você está preparando com alguma coisa ali na mão, na hora, para desenvolver isso. Você vem com algum material preparado você vai ter 50 minutos para tocar aquilo, quando você percebe em tal turma aquilo não vai funcionar. Daí você tem que vir com outra estratégia.

Citrino

Eu tenho muita facilidade de improviso. E essa facilidade de improviso já me salvou de muitas situações no cotidiano da sala de aula. Eu acho que o professor tem que ter esse jogo de cintura, ele não pode ser engessado. Então, o que para muitos seria um empecilho, um obstáculo.... Você tem que trabalhar com esse obstáculo e fazer com que se torne um agregador, um facilitador para você.

Ametista

Então assim, eu me sinto autora nesse momento em que eu transformo a minha aula. O meu planejamento não está só no papel, mas eu sei que ele é flexível, que eu posso adaptar. Por exemplo, surge uma questão de ciências no meio da aula de matemática. Você já deve ter ouvido isso: - ah, mas agora é matemática, na aula de ciências a gente vê. Eu acho um absurdo, eu não admito esse tipo de coisa.

Esmeralda 
Às vezes eu preparo uma aula. Faço todo o esqueminha: vou usar isso e isso. Chega na hora e aquilo dá uma direcionada... a participação dos alunos... eles exigem outros focos. Às vezes uma imagem ou um vídeo que você programou, você acaba não usando ou às vezes usando um outro foco e buscando um novo direcionamento. Então eu não posso dizer que é algo muito fechado não.

Opala

Os momentos em que os professores trouxeram a questão do improviso se relacionou com a pergunta "Você percebe a autoria docente em sua prática?". Cabe ressaltar que este improviso como prática autoral é consequência da segurança que o professor tem no seu planejamento, em sua própria prática, e em sua experiência como docente. Schön (2000) nos ajuda a compreender isso por explicar que a improvisação faz parte das estratégias situacionais que o profissional produz para lidar com um cenário incerto, que emerge em seu cotidiano profissional. Para que seja possível a expressão da autoria docente por meio da improvisação, o professor precisa ter como prática a reflexão sobre a teoria e sobre a prática. Improvisar não significa trabalhar com o achismo ou com o desconhecido, significa abrir espaços em seu planejamento para a incerteza do cotidiano. Tal perspectiva aparece em uma das falas dos docentes.

Eu não sei se a palavra seria muito improvisação, sabe?! Dá uma intenção de uma coisa solta, sem fundamentação, uma coisa muito etérea. Sem preparação e sem teoria por trás. Aí eu já contesto. Aí eu já sou contra. Eu acho que a fundamentação teórica que eu tenho, enquanto do ponto de vista da minha disciplina que é geografia, quanto da formação da docência me traz essa segurança de improvisar com o cunho teórico.

Esmeralda.

Percebemos na fala do docente que as criações oriundas da improvisação são pautadas tanto na reflexão sobre os saberes do conteúdo, quanto sobre os saberes da docência. O professor reflete sobre todo o seu repertório de conhecimento e experiências para enfrentar os desafios que emergem da sua prática. 
Essa reflexão abre caminhos para a construção de um profissional com autonomia para intervir em contextos que por vezes são complexos e incertos (CONTRERAS, 2010), desdobrando-se, nesse sentido, em práticas autorais, pois o professor consegue criar e agenciar novas estratégias de ensino a um planejamento prévio, a depender da resposta do seu contexto e dos seus alunos. Dessa forma, a improvisação como prática autoral docente está relacionada com a consciência do professor sobre sua autoridade com relação ao conteúdo, aos saberes da docência, e aos saberes oriundos de sua experiência docente que o possibilita construir estratégias para atuar em zonas incertas da prática educacional, acionando elementos da autoria e da criatividade.

A terceira prática autoral apontada pelos entrevistados é a criação e adaptação de recursos educacionais e ainda outros materiais pedagógicos, considerando o contexto do aluno e da escola. Na revisão de literatura sobre as práticas educacionais que os professores fazem dos RED vimos que é comum a realização de adaptações de um recurso ao ser inserido no planejamento do professor e na prática em sala de aula. Ao tentar aproximar um recurso educacional ao contexto específico de aprendizagem do aluno, o professor lança mão de um processo autoral pela adaptação. Beaven (2013) explica que a adaptação de um recurso para o contexto do aluno pode ocorrer de diversas formas, pode envolver modificações físicas ou modificação de um objetivo educacional de um recurso, para que seja adequado a outro propósito. Também acrescentamos ao processo autoral de adaptação quando o professor utiliza um objeto, a princípio sem intencionalidade pedagógica, e o transforma em um recurso educacional que dialoga com seu contexto de sala de aula. Vejamos como se manifestam estas práticas autorais nos excertos a seguir:

Foi um roteirinho de perguntas. Eu me inspirei essa daqui numa matéria que eu vi na Nova Escola, eles tinham... Porque, como eu estava estudando a BNCC eu vi que tinha muito material de sugestões de aula com o uso de imagens, como cultura digital, muita coisa. Então a partir daí eu adaptei um roteiro para que eles fizessem a análise das imagens.

Diamante 
Eu me incomodo muito com isso. Cadê a nossa autonomia? Cadê a identidade da escola, né?! Quando você me fez essa pergunta eu lembrei que nós recebemos um roteiro pós conselho de classe e aí a nossa tutora pedagógica me entregou aquela folha impressa e eu falei: - você tem esse documento em Word editável? Um documento editável. Ela falou: - eu tenho. Então, por favor, porque várias questões aqui não se encaixam no nosso contexto e eu preciso adaptar, né?! Eu vou assinalar o quê ali se não diz respeito à minha realidade? Ela me deu uma olhada e falou: - Não, tudo bem, eu te encaminho. E eu reelaborei todo ele. Não perdeu a essência, óbvio né?! A gente tem que respeitar as diretrizes, mas eu reorganizei o documento e dei a cara do colégio. Então nesse momento eu senti algo que é nosso, que eu fui autora, entende?

Esmeralda

Eu parto de algo que alguém já fez. Então eu posso adequar, melhorar... melhorar entre aspas porque eu não sou melhor do que ninguém. Mas eu posso adequar às necessidades dos meus alunos, aos objetivos que eu quero atingir. Então aí é a minha autoria, porque com os meus alunos eu conheço a realidade deles, eu conheço a realidade que eu vivencio, então é minha autoria. Mas o ponto de partida, alguém já fez isso antes.

Jade

Me sinto autora o tempo todo. Porque não tem como você reproduzir... pelo menos na minha prática eu não consigo pegar um texto e simplesmente comentar ele nu e cru, sem fazer a contextualização com o que está acontecendo atualmente, ou puxar um gancho se há um texto referente. Eu trabalho com história da ciência, né?! Então assim, buscar como era a sociedade daquela época, quais eram os conceitos daquela época, qual era o tipo de homem que aquela sociedade estava querendo formar pelo campo educacional. Então eu não consigo trabalhar fechada nesse campo. Então, por isso eu acho que a autoria é o tempo todo, quando você dá os teus conceitos e os conceitos que a sociedade também está querendo no teu trabalho. 
Podemos analisar, a partir das falas dos docentes, que existe uma forte preocupação em aproximar recursos educacionais ao contexto da escola e do aluno por meio de adaptações. Essa reincidência da adaptação do recurso pelo professor, visando o contexto do aluno e da escola, foi reconhecida na edição de 2016 da pesquisa TIC e Educação. O estudo mostrou que apenas $16 \%$ dos professores respondentes afirmaram utilizar um RED sem realizar nenhum tipo de modificação ou alteração de conteúdo, enquanto que $87 \%$ disseram ter realizado algum tipo de alteração em materiais baixados ou copiados. Também na análise dos dados quantitativos desta pesquisa observou-se que, ao ser questionado sobre a adaptação de RED encontrados em repositórios, 50,1\% dos professores disseram realizar adaptações "às vezes", enquanto que 23,5\% afirmam realizar adaptações frequentes, mostrando assim, que a adaptação de recursos é uma prática autoral recorrente no cotidiano do professor.

A importância da contextualização da prática docente é vista por Contreras (2010) como atributo da autonomia docente. Segundo o autor, para formar as competências humanas básicas para o cidadão do século XXI, a tarefa do docente não é simplesmente ensinar conteúdos descontextualizados, mas definir e planejar situações em que os alunos possam construir, modificar e reformular conhecimentos, atitudes e habilidades. Nesse sentido, a autonomia do professor ao refletir sobre a sua prática o impulsiona a contextualizar e situar recursos, estratégias e conteúdos à realidade da escola e dos alunos, se constituindo como uma prática autoral.

Ainda no campo das adaptações dos recursos como prática autoral, os professores entrevistados diferenciam mais um tipo de modificação de recursos, mas desta vez como uma ressignificação de artigos de diferentes origens e formatos, em recursos com intencionalidade pedagógica, como podemos observar nos fragmentos a seguir:

Para trabalhar com os professores para que depois eles desenvolvessem propostas com os alunos da EJA. E foi interessante porque aí eles perceberam que não precisa ter o material pronto no livro didático, mas que você pode, a partir de notícias e de imagens do dia a dia, desenvolver uma proposta de leitura e de letramento e que os alunos deram sentido para o texto 
porque moradia é um problema social. Tenho certeza que com os adultos, alguns deles teriam alguma vivência sobre esse assunto.

E aí eles desenvolveram práticas, não só na língua portuguesa, mas eles acabaram desenvolvendo práticas também em história, sociologia. Então a partir do tema moradia que estava lá no jornal apenas como tema de uma notícia, mas eu que aí eu utilizei essa fonte como material didático... uma proposta inédita. Então a partir dali houve autoria, porque eu utilizei aquele texto como subsídio, mas a partir dali teve uma parte que foi minha, de desenvolver a prática com aluno, utilizando o texto como suporte.

Diamante

Eu queria mostrar como representar e também levar à reflexão o risco de você trabalhar com o currículo fragmentado em relação à totalidade. Aí eu levei um quadro de semiótica. E o que eu pensei foi iniciar a conversa... eu levei um vídeo que eles falam sobre a academia, ele é do Aristóteles e Sócrates. Vai contando como é que era toda aquela relação da época para chegar ao conhecimento através de perguntas... mas mostra uma obra de arte e a partir da obra faz toda esta reflexão. Então eu queria falar um pouco disso assim... como que se chega ao conhecimento e eu tive a oportunidade de ilustrar com esse vídeo.

Opala

Mas eu adaptei... adaptei não... eu penso nas aulas para a EJA utilizando imagens, mas que eles, diante destas imagens, criem, evoquem, problematizem e deem novos sentidos, né?!

Diamante

A partir das falas dos docentes percebe-se que eles consideram como prática autoral a ressignificação do objeto em uma nova prática. Os fragmentos são repletos de experiências em que os professores trouxeram elementos como imagens, vídeos, reportagens de um jornal, que não necessariamente foram criados para uso pedagógico, mas que a partir de um processo autoral foi ressignificado dentro de uma proposta pedagógica contextualizada. De acordo com Soares e Santos (2012, p.2), artefatos técnicos diversos entram nas escolas através de alunos e professores 
e "em meio aos processos pedagógicos cotidianos, uns e outros articulam usos que fazem desses artefatos com usos que fazem daqueles considerados, por força do hábito, eminentemente escolares". Esse uso dos artefatos de forma a reapropriá-los em um contexto educacional é uma prática autoral, pois o uso feito dependerá da capacidade inventiva do professor, assim como da sua experência profissional e do contexto de trabalho.

Por fim, os professores abordam que o desenvolvimento de práticas autorais é benéfico tanto para o aprimoramento profissional do professor, quanto para os alunos, sendo esse o tema da terceira subcategoria.

\section{Influências da autoria docente}

Na subcategoria "impactos da autoria docente" os entrevistados tratam de suas percepções sobre os desdobramentos das práticas autorais em seu desenvolvimento profissional e no processo de aprendizagem dos alunos. Os resultados mostram que as influências da autoria docente estão (i) na afetividade na relação professor-aluno, (ii) no interesse do aluno pela aprendizagem.

Os docentes acreditam que o aluno percebe um grau maior de dedicação do professor que é autor e isso, por sua vez, influencia na afetividade e na confiança na relação professor-aluno. Como pode ser verificado nos seguintes fragmentos:

Eles veem que naquilo houve um processo de dedicação. Você gastou um tempo para fazer isso, né?! Então eles falam: - mas por que você fez isso? - Eu quis fazer para vocês, eu trouxe. Eu fiz para vocês. Então, eles entendem isso.... - Cara, esse cara se dedica mesmo.

Quando eu levo alguma coisa para a sala de aula e eu construí aquilo. Eles sentem que eu fiz aquilo com carinho porque era para eles. Então: - ah, mas quem fez isso? Fui eu. É um cartaz, um gráfico...

Ametista

É visível a mudança. Esses professores, eles são amados... adorados pelos alunos... porque tem sempre algo novo, sabe? Tá 
cativando, tá despertando uma curiosidade. Tá despertando o potencial... e eles gostam disso. Porque assim, eles mesmo falam... eles nos procuram. Tem muitas situações que eles nos procuram e dizem: - hoje tem aula com o professor tal [tom de desânimo] HOJE TEM AULA [tom de alegria], entende? Então mesmo nessa fala você percebe os alunos, como você motiva, como você consegue envolvê-los na aprendizagem quando você é criativo

Esmeralda

Eu penso o seguinte: que a partir do momento em que o aluno sente que ele tem ofeeling, que ele sente mesmo que você está ali para o que der e vier. Que você está ali para ensinar, que você quer que ele aprenda, que isso vai em um dado momento, seja qual for da vida dele, vai ter um significado... Quando ele sentir que você quer que ele faça o diferente para a vida dele.

Ametista

O trabalho docente é um trabalho interativo, pois tem como objeto as relações humanas, e essa especificidade do trabalho docente se associa com a afetividade. Segundo Leite (2012), a mediação pedagógica, nesse caso, realizada a partir das práticas autorais, é de natureza afetiva e, dependendo de como é desenvolvida, produz impactos afetivos, positivos ou negativos na relação que se estabelece entre professor, aluno e conhecimento. No caso das práticas autorais apontadas pelos professores, percebe-se que a autoria influencia em uma maior aproximação entre aluno e professor, desencadeando no fortalecimento de vínculos afetivos. Elementos como a dedicação do professor e a criatividade em elaborar propostas pedagógicas ou recursos educacionais coopera para que o aluno se sinta mais motivado e curioso.

Nesse sentido, as falas podem indicar que a afetividade interfere diretamente na aprendizagem e está implícito no fazer pedagógico de um docente autor. Pesquisas como de Veras e Ferreiras (2010) e Castro, Melo e Campos (2018) evidenciam que a postura do docente influencia a aprendizagem dos alunos, inclusive em aspectos como permanência ou evasão de um curso. Dessa forma, acreditamos que pode haver relação entre a criação de vínculo afetivo com os alunos, quando o professor desenvolve práticas autorais. 
O segundo resultado sobre o impacto da autoria docente versa sobre o processo de aprendizagem. Nesse caso, o aumento do interesse do aluno pelo seu processo de aprendizagem. Assim como nos resultados dos dados da questão aberta, em que a motivação para o uso do RED dialogava com a expectativa do professor que a utilização do recurso aumentaria o interesse do aluno pela aprendizagem, existe também a percepção de que as práticas autorais contribuem para o aumento do interesse dos alunos. Na visão dos professores:

Desde o desenvolvimento deles, desde a questão de desempenho, de rendimento escolar. Você observa que é melhor, muito mesmo.

Esmeralda

O aumento do interesse deles, né?! Você leva uma coisa diferente e o interesse da turma inteira aumenta muito. E quando você não vai dando as respostas, você vai dando as perguntas e faz com que eles lancem coisas para chegar a uma conclusão e você vai intermediando isso... o ganho é muito superior do que aquela aula só discursiva que você fazia, né?! Eu fiz muito isso.

Citrino

Percebi um maior interesse e uma maior interação.

Jade

Este resultado evidencia que a aprendizagem dos alunos é considerada um dos principais objetivos do processo de ensino e, por isso, existe a preocupação dos professores em criar práticas pedagógicas que instiguem o interesse e a motivação do aluno, sejam tais práticas com o uso da tecnologia ou não.

De uma forma geral, a categoria "concepções sobre a autoria" procurou discutir como os professores compreendem a autoria, as manifestações deste conceito em sua prática docente, assim como a consequência dos processos de autoria docente na vida do aluno. A figura 16 sintetiza os achados desta categoria. 


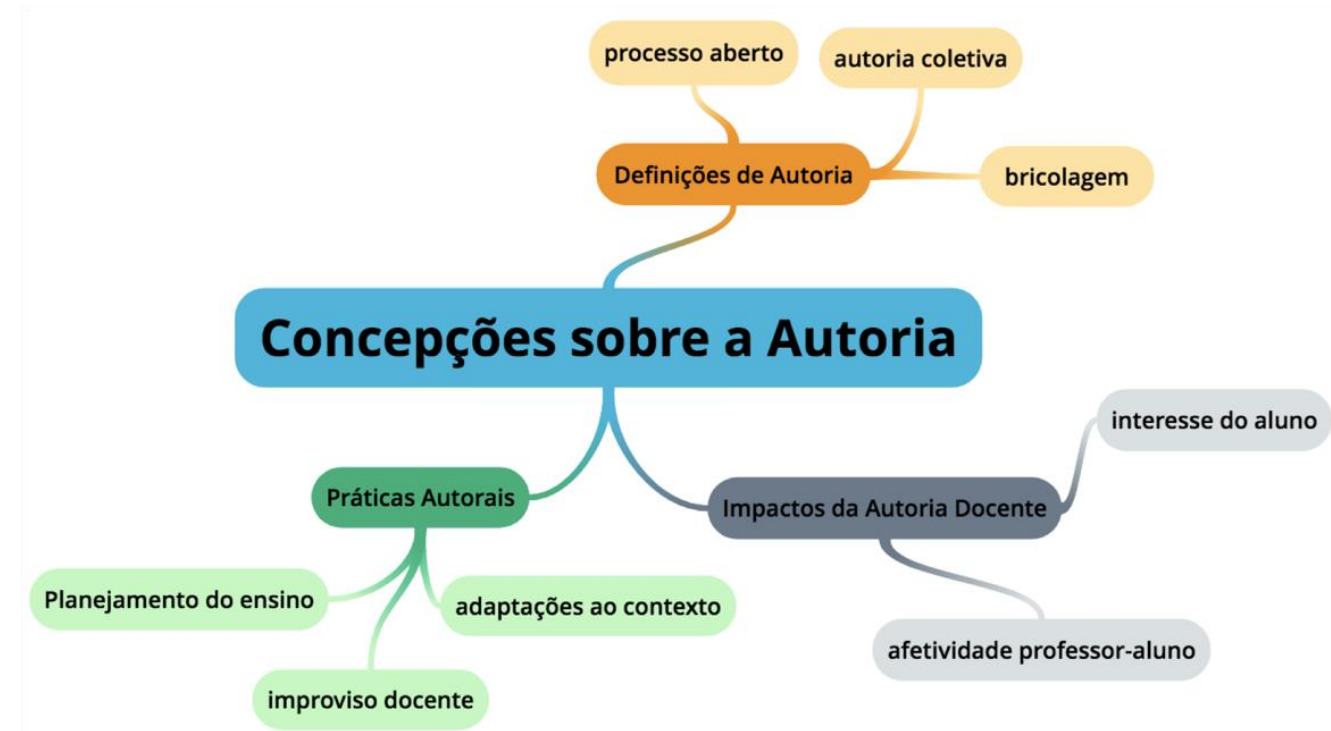

Figura 16 - Resultados da categoria "Concepções sobre a Autoria". Fonte: Elaboração própria.

\subsection{2}

\section{Percurso para a autoria docente}

A categoria "percursos para a autoria docente" está diretamente ligada ao desenvolvimento profissional do professor. Centramos aqui nossos esforços para compreender o caminho que leva um professor a se tornar autor. Como abordado na revisão de literatura, apontamos que as origens da autoria docente podem ter relação com o contexto criativo e a coletividade em que professor se insere e ainda com o comprometimento do docente com o seu desenvolvimento profissional, passando pela reflexão, autonomia e contextualização de suas práticas.

A análise dos dados que originaram essa categoria nos leva a entender que não existe um percurso padrão para que o professor se torne autor, mas conseguimos identificar a associação de alguns elementos que podem influenciar na construção da autoria docente, a saber (i) as características da formação docente e inspiração em professores, (ii) trocas com os colegas; (iii) compromisso com o seu desenvolvimento; (iv) construção familiar e crenças. Nossos dados concordam com a proposição de Tardif (2000, p. 14) sobre a construção da identidade docente, pois segundo o autor:

Os saberes profissionais dos professores são variados e heterogêneos em três sentidos. Em primeiro lugar, eles provêm de 
diversas fontes. Em seu trabalho, um professor se serve de sua cultura pessoal, que provém de sua história de vida e de sua cultura escolar anterior; ele também se apoia em certos conhecimentos disciplinares adquiridos na universidade, assim como em certos conhecimentos didáticos e pedagógicos oriundos de sua formação profissional; ele se apoia também naquilo que podemos chamar de conhecimentos curriculares veiculados pelos programas, guias e manuais escolares; ele se baseia em seu próprio saber ligado à experiência de trabalho, na experiência de certos professores e em tradições peculiares ao ofício do professor.

Embora Tardif (2000) trate da construção da profissão docente de uma forma mais ampla, ao longo das discussões dos resultados desta categoria podemos observar que na construção da autoria do professor também existe uma bricolagem de fontes e saberes, sendo muitos deles os mesmos que Tardif identifica como parte e necessários para a construção da identidade docente.

O primeiro resultado como relevante para o percurso para a autoria docente foi a qualidade da formação do professor, e nesse resultado aparecem fatores da formação inicial e continuada. Percebemos que essa formação se caracteriza pelo olhar crítico e pelo diálogo da teoria com a prática, como se observa nos seguintes fragmentos:

E nesta formação eu tive que desenvolver planos de aula e a orientadora deste curso, ela vinha até Foz para fazer as análises. Então foi bem interessante não só pensar o plano de aula, a implementação, mas depois ela analisava e dava feedback (...) Mas na época foi bem interessante porque eu vinha de uma formação bem mais tradicional e a partir daí as minhas aulas foram mais dinâmicas.

Diamante

Essas atividades... é uma construção, na verdade. Porque desde o ano 2000 nós estamos aí e são mais de 10 anos de leituras, de cursos que eu realizei para buscar alternativas para facilitar o meu trabalho. Porque com 40 horas semanais e com 500 alunos é uma carga muito pesada. Então o que eu resolvi foi encontrar alternativas para facilitar o meu trabalho. 
Tanto que a minha formação é biologia, depois de 10 anos eu fiz pedagogia. Aí eu fiz a primeira especialização em educação interdisciplinar, que é uma coisa que eu já gostava. Porque eu fiz biologia, mas não porque eu amava exclusivamente a biologia, mas eu amava história, eu gosto de língua portuguesa, de literatura, eu gosto de filosofia. Então assim, é meu... eu já não consigo andar numa linha reta.

Opala

Eu estudei numa instituição pública de muito qualidade, eu tenho muito orgulho disso e faço questão de frisar, sabe?! E nós tivemos mestres que hoje são para mim referência.

Esmeralda

Os professores também apontaram em suas falas a importância que foi para a sua formação a participação no Programa de Desenvolvimento Educacional (PDE), promovido pela secretaria estadual de educação do Paraná. Segundo Duarte e Viriato (2012), foi uma das modalidades de formação continuada ofertado pela rede estadual entre os anos de 2003 e 2010 e era operacionalizado pelas universidades situadas no estado e diretamente ligado ao desenvolvimento do plano de carreira dos professores. De acordo com os autores, o PDE era voltado para a qualificação e titulação dos docentes, e, mediante processo seletivo, assegurava os seus afastamentos da sala de aula por dois anos para se dedicarem ao programa de formação. Os professores trazem em suas falas algumas das contribuições dessa formação específica.

Eu sempre fui uma professora que busca, assim, ... fundamentar a minha prática com bastante estudo. E aqui no Paraná nós temos política (tínhamos porque agora ela não está sendo... nos últimos anos a gente não teve mais essa oferta). Mas eu participei como coordenadora do PDE, do qual o professor se afasta durante dois anos para que ele possa retornar para a universidade e fazer formação continuada de fato. (...) E aí, além de você desenvolver a sua pesquisa, você tinha de partir de um problema que tivesse lá na sua escola. E você poderia desenvolver com vários pontos, ou 
com o professor, ou com o aluno, ou com a direção da escola. No primeiro ano era mais a formação e no segundo ano você tinha que implementar (...) E nesse programa você também produzia material didático. Uma das suas obrigações durante o programa era produzir material didático e aplicar.

Diamante

No Paraná a gente teve um programa até 3 ou 4 anos atrás em que nós podíamos fazer... era quase um mestrado (...) Para mim, eu acho que foi uma realização pessoal muito grande, eu participei do Congresso Nacional de Geografia, publiquei trabalho, já tenho três artigos publicados. Então, eu acho que sim, muito desta caminhada tem a ver com ser autodidata, querer buscar.

Ametista

Seja na formação inicial ou continuada, nota-se que os docentes consideraram importantes para o seu processo um tipo de formação diferenciada de um programa tradicional, sendo valorizado por eles a interdisciplinaridade, diálogo da prática com a teoria e o próprio PDE que trazia a experiência de utilizar o campo de trabalho do professor como foco da especialização, no sentido de promover soluções para aquela realidade educacional, e o fomento à produção de material didático direcionado para o contexto da escola.

Ainda no campo da formação de professores, um entrevistado ressaltou a importância que alguns docentes (da vida escolar e da formação profissional) tiveram em seu percurso autoral. São retratadas práticas diferenciadas, motivação ou inspiração que tais docentes causaram nos entrevistados, e que os fizeram ter uma visão diferenciada da prática profissional do professor, como pode ser examinada a seguir:

Então, teve uma professora que até hoje (foi em 2007 ou 2008). Então você vê, são 11 anos que se passaram e ela já veio duas vezes ou três vezes aqui para a cidade onde eu moro, a meu pedido dar cursos para os professores. A gente tem uma relação de produção muito grande (...) $\mathrm{Na}$ minha especialização, o professor de cartografia. Ele me passou, me marcou muito, me puxou para a 
formação da cartografia, uma coisa que tem que ser perfeita mesmo, sabe?!

E esse outro professor também, na verdade do meu ensino fundamental, que ele brincava muito com o que a gente chama hoje de gamificação. Ele levava muitos jogos para a sala de aula (...). E hoje a gente fala muito dessa coisa de gamificação. Eu vejo quanto isso foi importante depois na minha prática como professora, também, de ter essa coisa de brincar.

Ametista

Você vai procurando, você vai buscando. Às vezes um colega te dá uma ideia básica ou um site que tenha alguma prática, eu acabo indo muito no involuntário mesmo.

Opala

Um segundo elemento que foi identificado como importante para a construção da autoria docente foi a troca com os pares. Trouxemos o conceito de coletividade para discutir como ela estaria presente na identidade docente. Conforme explicou Passos et al. (2006), a coletividade faz parte do processo de formação do professor pois se reflete em um contexto favorável para a aprendizagem continuada do docente. Também para Tardif, Lessard e Lahaine (1991), as relações com os pares são na verdade confronto entre os saberes produzidos pela experiência coletiva dos professores, e são importantes para que esses saberes tenham objetividade. De acordo com os autores, "cotidianamente os professores partilham uns com os outros seus saberes através dos materiais, dos "macetes", dos modos de fazer, dos modos de organizar a sala de aula". Consideramos como isso se dá na construção da autoria docente:

Tenho 27 anos de profissão e no meu primeiro ano eu tive uma diretora que me ensinou muito. Na verdade, eu aprendi a ser professora com ela, e nós não tínhamos material didático, nós tínhamos que criar textos, elaborar textos para trabalhar com o ensino médio. Então neste momento eu já me deparei com a necessidade de criar algo para a sala de aula, para as necessidades de ensino e aprendizagem.

Não só com a diretora, mas com a equipe pedagógica da escola e o grupo de professores que junto entrou comigo na escola. Porque eram jovens, eram um grupo grande de jovens das escolas da 
periferia de Curitiba. Uma escola que a maioria dos professores mais velhos não queria ir trabalhar, pelas características, perfil do bairro, perfil do público (...) Então, nós éramos um grupo bem grande e a troca de experiência foi fundamental.

Jade

No caso do professor Jade percebemos que a troca com seus pares no início de sua atuação como docente foi significativa para o seu aperfeiçoamento como professor autor, pois foi a partir daquela realidade, juntamente com as trocas com os colegas, que se sentiu compelido a criar recursos didáticos que se adequassem à sua realidade educacional.

$\mathrm{O}$ terceiro elemento apontado pelos docentes, que corroborou para o percurso da autoria, foi o comprometimento com o seu desenvolvimento profissional. No capítulo teórico discutimos como o compromisso do docente com o seu desenvolvimento possibilita ao professor rever, renovar e desenvolver o seu compromisso como agentes de mudança. Isso demonstra que o professor que se sente mais implicado com seu contexto, e que se preocupa na transformação constante da realidade em que atua, pode ser também o professor que consegue construir mais práticas autorais. Sobre esse tema, os docentes entrevistados consideram:

Então, eu penso que eu, a profissional que sou hoje... eu sempre me proponho que amanhã eu tenho que ser melhor do que eu fui hoje. Isso eu sempre digo para os meus alunos, para os meus colegas de trabalho, que é uma proposta minha, uma proposta de vida. Então eu penso que é o dia a dia, é a rotina ali, são os percalços que vão contribuindo para a nossa formação. Hoje eu fiz assim, deu certo, ótimo. Vamos aperfeiçoar. Não deu, eu preciso rever, eu preciso melhorar, amanhã eu tenho que fazer diferente.

Esmeralda

Então eu entendo que o professor, o pedagogo, o profissional da educação... enfim. Para ser autor não é um passe de mágica, não do tipo do dia para a noite e exige também muito conhecimento. Não só teórico, mas o conhecimento da prática, muita prática, muitos erros, muitos acertos, muita reflexão sobre essa prática. 
Que eu digo que não tem prática sem ação né... eu preciso sentir minha prática para gerar nova prática.

Diamante

Eu observo que isso é muito claro. É você associar a teoria com a prática, isso é óbvio, mas às vezes não é possível. Você vai no improviso, você vai e faz o que você considera melhor, sem achismo, mas com uma bagagem que você tem e sempre tentando fazer o melhor. Mas o que nos dá esse respaldo, essa segurança de eu ser essa autora é a experiência, é a prática.

Esmeralda

Nos discursos dos professores podemos perceber que existe comprometimento com a melhoria contínua de sua atuação, e a compreensão da reflexão sobre a prática como condição deste processo. $\mathrm{O}$ diálogo entre a teoria e a prática parece ser valorizado pelos docentes no seu desenvolvimento profissional, e, ao mesmo tempo, percebemos uma valorização dos conhecimentos oriundos da prática. Se na formação inicial o conhecimento teórico tem, na maioria das vezes, o foco no currículo de formação dos professores, a fala do professor que se preocupa com seu desenvolvimento foca-se na prática, e em como melhorá-la a partir da sua reflexão pautada em conhecimento teórico.

Mais uma vez, trazemos a importância da reflexão dos saberes das práticas e do cotidiano como elementos que podem possibilitar a autoria docente através da reconstrução do conhecimento do docente a partir de suas percepções sobre a prática.

Os últimos elementos apontados pelos docentes como relevantes para o percurso da autoria docente são aqueles inerentes à individualidade do professor e antecedem à sua formação pedagógica e mesmo à sua prática profissional. Estes foram discriminados como as crenças e influências familiares.

Ao tratarmos sobre o desenvolvimento da criatividade docente, vimos que muitas pesquisas (OLIVEIRA; ALENCAR，2014; WECHSLER，2005; STERNBERG; LUBART, 1996) consideram que a construção de uma pessoa criativa tem relação com fatores internos e externos ao indivíduo. Wechsler (2005) explica que existem muitas varáveis para a construção da criatividade, tais como a 
cognição, características da personalidade, aspectos familiares, educacionais, sociais e culturais, em que, interagindo entre si, dão origens aos estilos de pensar e criar em diversas formas.

Seguindo uma linha de raciocínio similar, os professores explicitam de que maneira elementos tais como as crenças e as influências familiares corroboraram para o processo de construção da autoria docente. Como pode ser observado nas seguintes colocações:

Isso de trajetória é assim com experiência de vida, tem a ver muito com a influência que eu tive da minha família, tem muito a ver com a vontade que eu tinha de conhecer mais, de saber mais. Eu nunca fui uma pessoa que me contentava com o simples conhecimento. Então, eu queria ir além, entendeu?

Ametista

Eu acho que é uma coisa da minha educação, é cultural, é histórico... enfim... não sei. Mas eu sempre fui... fui diretora de escola seis anos, sempre briguei. Sabe essas brigas pedagógicas? Eu sempre briguei pelo o que era justo.

Eu penso que é da educação da minha família. Da educação que eu tive, porque a minha base é a minha família. A minha mãe .... os meus pais sempre foram pessoas muito corretas. Muito correto de dizer para você não aceitar as coisas como são, para você sempre buscar o outro olhar. Porque nós às vezes nos habituamos de ver aquela imagem, minha mãe sempre disse; - mude o ângulo, olhe de outra forma. Não tem outra resposta para isso?

Esmeralda

Eu acho que é muito do indivíduo, né?! Cada profissional... têm uns que eles se conformam em estar lá e fazer a chamada, ir para a lousa e escrever alguma coisa ou falar página tal, exercício tal. Eu não me encaixava nesse perfil.

Citrino. 
Embora a fala dos professores não traga elementos mais palpáveis sobre quais aspectos foram desenvolvidos que se relacionam com a autoria docente, percebemos que os fragmentos destacados abordam como que a capacidade de não se conformar com uma dada realidade o fizeram buscar novas formas de pensar, agir e lecionar. Sendo que alguns professores apontam que essa forma diferente de encarar a realidade foi fomentada pela família em sua trajetória histórica.

A figura 17 condensa os elementos abordados pelos professores que foram mapeados como significativo para o percurso da autoria docente.

\section{Percurso para a Autoria Docente}

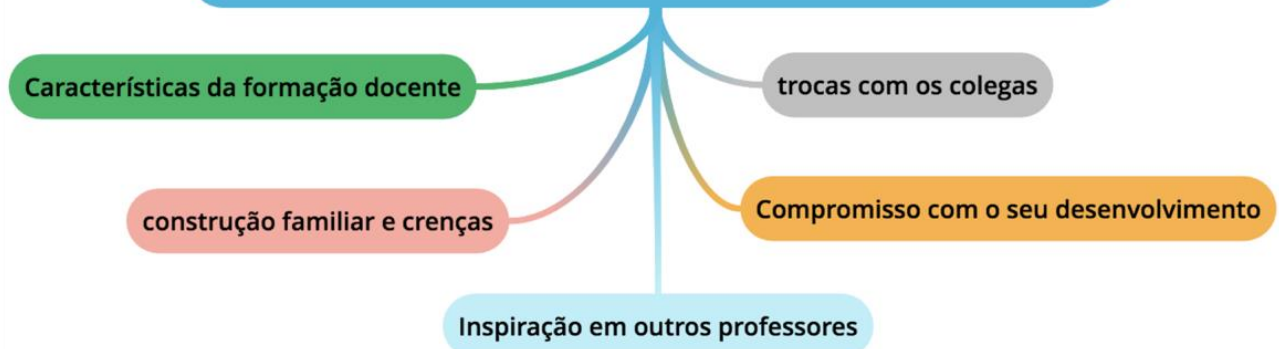

Figura 17 - Resultados da categoria "Percurso para a Autoria Docente". Fonte: Elaboração própria.

\subsection{3}

Relações da autoria docente com as tecnologias

Considerando que o tema central da tese versa sobre a autoria docente e as práticas com os recursos educacionais digitais, a presente categoria aborda as relações que existem, segundo os professores entrevistados, entre a autoria docente e as tecnologias. A categoria contempla três subcategorias que serão discutidas em prosseguimento, a saber: i) uso do RED e outras tecnologias, ii) criação de RED e de atividades com RED, e iii) desenvolvimento de competências digitais para o trabalho com os RED.

\section{Uso do RED e outras tecnologias}

Na subcategoria "uso do RED e outras tecnologias" tentamos compreender quais eram as principais práticas educacionais realizadas com os recursos educacionais digitais. Durante a entrevista, embora tivéssemos perguntado 
diretamente sobre os RED, os professores trataram também de práticas educacionais realizadas com outras tecnologias, tais como redes sociais e diferentes suportes midiáticos.

Com respeito aos tipos de RED, nota-se a utilização de imagens, vídeos, slides e mapas mentais. Os RED citados vão ao encontro dos dados descritos a partir da resposta ao questionário (pág. 118). Quanto ao tipo de práticas realizadas, podemos observar que os tipos de usos apresentados se relacionam ao conteúdo que está sendo trabalhado pelo professor. Os RED se apresentam como uma ilustração do conteúdo ou como uma forma de aprofundar o conhecimento e consolidá-lo, instigando o aluno a desenvolver maior interesse. Em ambos os casos, vemos que tais usos envolvem a oferta aos alunos de novas experiências de aprendizagem do conteúdo e se relacionam com os resultados encontrados na subcategoria "processos e resultados de aprendizagem", provenientes dos dados explorados na questão aberta. Podemos notar como os professores descrevem suas práticas com os RED:

Os vídeos, eu os trago para dois momentos a depender do caso. Ou eu trago para despertar a curiosidade para um conhecimento, um conteúdo que nós vamos desenvolver. Ou eu trago para reflexão, depois de já ter trabalhado todo o conteúdo. As imagens, geralmente, são durante as apresentações para ir buscar, para instigar a conversa que nós estamos discutindo. Os jogos geralmente são para frisar algum conceito que nós já trabalhamos. E o Google Drive é para atividades, para textos complementares, para lembrete, para revisão de atividade.

Opala

Eu uso para trabalhar estruturas atômicas. As estruturas são tridimensionais e difíceis de desenhar e aí quando você colocava a estrutura de um cálcio, de um sódio e você vai mostrando a diferença de estrutura de molécula atômica... Aí eu acho que fazia com eles, além de ter uma visão maior, despertava um interesse a mais, né. 
Utilizo muitos vídeos, principalmente de produções de universidade. Eu gosto muito dos vídeos... tem uma série de civilizações que é fantástica. Eu utilizo vídeos, utilizo muito o Datashow. Na sala de aula a TV Pendrive ${ }^{15}$ ainda está presente, o pendrive ainda está na sala de aula. Hoje eu também tenho utilizado a sala de aula do Google Classroom, então as atividades que eu proponho, os trabalhos que os meus alunos fazem ali na sala de aula. Nós temos também a lousa digital na escola. É um material que eu também uso muito.

Jade

Eu uso muito a TV Multimídia e tenho este direcionamento para mostrar para os meus acadêmicos. A TV multimídia é um recurso muito bom, porque você trabalha com imagens, com vídeos, com documentários, com recortes, você pode montar. E eu trabalho bastante com jogos também, com os jogos que eu acho na internet. Com jogos que estão de alguma forma vinculados à disciplina.

Denise

Também são levantadas pelos entrevistados as atividades pedagógicas que são realizadas com diferentes tecnologias. As narrativas dos professores falam sobre como as tecnologias estão presentes na escola e como elas são utilizadas dentro e fora do contexto da sala de aula. Percebe-se que os usos descritos não são resultados de um uso crítico e autoral das tecnologias situadas em um contexto de aprendizagem específico. No entanto, situações pedagógicas como uso de provas on-line, jogos de realidade virtual em aulas de educação física e vídeo chamadas em reuniões pedagógicas ainda proporcionam uma experiência com a tecnologia, que, em muitos casos, só poderia ser vivenciada por alunos e professores dentro da escola. Como verificados nos seguintes fragmentos:

\footnotetext{
${ }^{15}$ A TV Pendrive é um projeto que prevê televisores de 29 polegadas - com entradas para VHS, DVD, cartão de memória e pen drive e saídas para caixas de som e projetor multimídia - para todas as 22 mil salas de aula da rede estadual de educação, bem como um dispositivo pen drive para cada professor (PARANÁ, 2019)
} 
Há um tempo atrás eu fiz uma timeline com a escola que estava tendo um conselho de classe. Eu falando com os colegas que eu fiz esta atividade de casa e eu falando com professores que estavam no conselho de classe (...). Aí a diretora foi lá e colocou o datashow, eu fiquei no telão.

Ametista

Na escola, nós temos multimídias em todas as salas, nós temos as caixas de som, nós temos microfones, nós temos uma sala só com o just in dance que eu acho o máximo. As crianças amam, sabe? Durante as aulas de educação física eles amam. (...) Não tem como fugir né?! Está presente em toda a escola e mesmo em contato com os pais, situações de agendar reuniões, nós estamos utilizando o Whatsapp.

Esmeralda

São alternativas que também podem atender às necessidades dos meus alunos. Ensinar a eles e também mostrar a possibilidade da tecnologia. Porque uma vez que eu fui fazer a experiência de uma prova on-line, muitos alunos tiveram dificuldade para acessar o site do colégio, do colégio que eles estudavam há cinco anos. Então nós fizemos várias atividades que foram permitindo o crescimento e o amadurecimento daqueles jovens de 15 anos.

Esmeralda

Um segundo uso dos RED descritos pelos professores é o compartilhamento. Verifica-se que o compartilhamento com os pares é realizado de forma constante em grupos e em outras formas de colaboração. Também se constatou que o ato de compartilhar um RED pode ser carregado de diferentes emoções e intenções a depender da sua tipologia: se é um recurso autoral, ou se é um recurso compartilhado de outrem.

Com relação aos recursos autorais, um professor pareceu indicar certa dificuldade em compartilhá-los quando estes são de sua autoria. Como podemos notar em sua fala, apesar de uma rejeição interna ao ato de compartilhar, parece existir a ideia de que o compartilhamento faz parte da prática docente, principalmente no caso deste professor, que também já atuou na formação 
continuada de outros professores. Neste sentido, notamos certo conflito entre o apego daquilo que é de sua criação e o "dever" ou a expectativa de compartilhar.

Apesar do ciúme, esse aí [RED criado pelo professor], como eu trabalho com isso, por mais que eu tenha um pouco de apego eu não posso guardar só pra mim, porque esse é o objetivo. Que você forme os professores e que eles apliquem lá na escola, apliquem com seus pares, este é o foco (...)

Eu tenho muita dificuldade em compartilhar aquilo que eu produzo (...)

Mas eu confesso para você que quando eu penso em compartilhar um slide que produzi de forma básica para que outro aplique, assim... Às vezes dá um sentimento de ciúme, porque primeiro eu penso assim: pra eu chegar nesta ideia e desenvolver levou bastante tempo, entendeu? E às vezes, assim, nem sempre aquele que vai aplicar, ele vai ter, assim... Por mais que você pegue um slide, para você conseguir fazer com que ele funcione com aquela proposta que o autor pensou você também teve que fazer suas leituras.

Diamante

Resultados similares foram encontrados na pesquisa de Pirkkalainen et al. (2017). De acordo com os autores, em uma pesquisa em que se estudou a atitude dos professores frente ao compartilhamento, quanto mais apego o professor tiver com uma ideia ou uma criação sua, mais difícil será para ele compartilhar esse conhecimento com outros.

Por outro lado, foram encontradas posições de educadores que defendem um compromisso na prática de compartilhamento. Nesse caso, eles não falam de suas produções especificamente, mas tratam o compartilhamento de recursos educacionais e do conhecimento como um "dever" do docente. Como pode ser analisado nos seguintes fragmentos:

Quanto mais pessoas estiverem discutindo a mesma coisa, acho que enriquece. Acho que as práticas educacionais, elas devem sim ser compartilhadas (...) 
Um trabalho com QRCode eu fiz com o professor de Geografia. Já fiz parceria com a de Filosofia também, da gente compartilhar material. Eu passava e ela me passava. A gente tá sempre compartilhando. Com a professora de Língua Portuguesa também, ela ia fazer a leitura de um texto sobre a revolução industrial e eu encontrei um livro que tratava sobre esse tema em PDF, baixei o livro e passei na sala de aula pelo Google Drive para os meus alunos. Fizemos uma atividade compartilhada.

Diamante

Eu compartilho o conhecimento, né?! É permitir que o outro tenha acesso, já que vai facilitar o trabalho dele também, a vida. Que ele possa aprender, que ele possa crescer enquanto profissional. É este o objetivo, é compartilhar o conhecimento tanto para o professor como para a escola $(. .$.

Jade

O compartilhamento que deveria ter e que houve, depois passou para todos da rede. Porque a nossa formação do PDE, ela era uma formação em rede. Inclusive tinha uma plataforma on-line onde eu era tutora, exercia tutoria mesmo para compartilhar essa produção, essa pesquisa, os resultados, as análises e até discutir com outros professores desde curso.

Diamante

Porque eu acho que é um tremendo egoísmo falar que é meu. Duplamente, né?! Porque, um, alguém já fez e eu estou lá disponibilizando. Segundo, porque eu vejo um cara que está ferrado, tá precisando de ajuda. Então por que não compartilhar? (...)

Tenho muita coisa que muita gente me envia e fala: - Cara isso é legal, envia para os professores. E daí você acaba criando uma corrente, isto é, uma corrente de compartilhamento.

Ametista 
Notamos, a partir das falas, que existe um otimismo e um senso de responsabilidade ao se realizar o compartilhamento. Nesse sentido, acreditamos que pode haver uma relação da crença, ou do ideal que o professor tenha sobre a educação e a vontade ou necessidade de compartilhar conteúdo e fazer o conhecimento circular. Segundo Algers e Silva-Fletcher (2015), ao se pesquisar sobre as motivações que leva o professor a utilizar e compartilhar um recurso educacional, vimos que influencia positivamente o comprometimento do docente com a dimensão democrática do conhecimento, a satisfação em compartilhar com os pares as afinidades e atividades colaborativas, e o compromisso com o ensino expansivo. Contreras (2012) também aponta o compromisso com a comunidade, considerando que as práticas profissionais do professor são constituídas no coletivo, como uma das dimensões por qual perpassa a profissão docente.

Assim, notamos que o senso do coletivo é um fator importante com relação às práticas de compartilhamento, assim como também é para a construção da autoria docente e para a profissionalização do professor (TARDIF, 2000).

\section{Criação de RED}

A subcategoria “criação de RED” se propõe a compreender não apenas quais tipos de RED são criados pelos professores, mas também quais são as percepções que eles têm sobre este processo autoral e sobre as práticas pedagógicas relacionadas com seu uso.

De modo geral, percebemos que a criação de RED não é uma prática tão comum entre os professores que foram entrevistados. Existe uma preocupação maior em saber como encontrá-los, como inseri-los no planejamento de ensino e adaptá-los para um contexto educativo, do que na criação de um recurso em si, como também foi discutido na subcategoria "práticas autorias". A ideia da pesquisa enquanto prática de criação de recurso é abordada nas seguintes passagens:

Tem produção minha que eu vou pincelando aqui e ali na internet, produzindo, copiando, colando. Faço slides, faço textos, faço pesquisa. Então é assim, você pode falar: mas é só uma pesquisa na internet, qualquer um pode fazer isso. Com certeza! (...) 
Só que eu acho assim, eu poderia dizer que (como que a gente fala?) é um meio plágio. Não chega a ser plágio porque eu referencio tudo que eu posso referenciar. Mas são pesquisas... porque você compilar tudo, juntar tudo. Às vezes são 10, 15 anexos. Dá trabalho!

Ametista

Aquilo, assim, não tem volta. Você vai atrás daquilo. Aí você fala assim... É tua autoria? Não é minha autoria... é aquilo que eu pesquiso, que eu aprimoro, que eu vejo que dá certo ou não. Aí eu acabo desenvolvendo alguma coisa para a prática docente (...) Específico que eu criei, não. É muito assim: eu pego algo que alguém fez, busco na internet, busco em livros e vou aprimorando de acordo com a minha realidade.

Opala

Verifica-se que os docentes realizam uma curadoria de conteúdo, no sentido de saber como pesquisar e encontrar as fontes e recursos para depois rearranjá-las, seja como texto ou como slides. Ao mesmo tempo que o professor considera esta produção como um "meio plágio" por partir da ideia de que a criação não é totalmente original, ele reconhece que existe um trabalho autoral que é proveniente da sua produção a partir dos resultados de sua busca.

Quanto à criação de novos RED, os professores citam frequentemente a produção de slides, especialmente dentro de contextos de cursos de formação continuada, a construção de materiais pedagógicos como livro didáticos e mapas mentais, como são descritos abaixo.

Por exemplo, quando nós tínhamos o GTR, que era o Grupo de Trabalho em Rede, tinha uma plataforma Moodle que você inseria o material didático lá e no portal também tinha umas sequências de aulas também que eu desenvolvi em forma de slides.

Diamante

Eu criei vários, já [RED]. Isso aí é uma ferramenta que eu utilizo bastante também [Power Point]. 
Eu participei de um programa no Paraná que é o PDE e a proposta de unidade didática, tinha que apresentar uma proposta pedagógica para os colegas e eu tive que preparar. Foram 8 encontros de 4 horas nesse curso e em todos eles eu tive que preparar um Power Point. E no segundo eu preparei com o foco nas pessoas que estavam presentes e as impressões que elas obtiveram das questões que nós estávamos discutindo, dos textos que nós estávamos debatendo e estudando.

Jade

Na época produzi o Folhas ${ }^{16}$. Então esse material você sabia que já fazia justamente para ser compartilhado (...)

Uso uma ferramenta para a criação de mapa mental, mas eu utilizei para fazer tipo um brainstorming sobre currículo. Foi bem legal.

Diamante

Como já foi discutido, em nossa revisão de literatura sobre as pesquisas que envolviam a utilização de RED por professores, encontramos como um dos eixos a tendência de pesquisas que focavam nas práticas pedagógicas com RED. Nos estudos analisados constatou-se que os recursos são utilizados principalmente para proporcionar novas experiências de aprendizagem para os alunos e que a prática do professor com os RED são, em sua maioria, sobre os usos e sobre as formas de adaptação (CLEMENTS; PAWLOWSKI, 2012; HILTON III; WILEY; LUTZ, 2012; BEAVEN, 2013; VAN ACKER et al., 2014). Os estudos que versavam sobre a criação de novos recursos eram contextualizados em projetos com o objetivo de fomentar a criação de RED pelos professores durante a execução do mesmo (HUGHES; MCKENNA, 2012; BAGETTI; MUSSOI e MALLMANN, 2017).

Tanto os resultados da análise dos estudos discutidos, como os resultados desta subcategoria, apontam que a criação de RED, quando consideramos a criação como um recurso planejado e desenvolvido inteiramente pelo professor, é mais difícil e complexa de ser realizada. Isto ocorre, quer seja pela facilidade dos professores em encontrarem e adaptarem os recursos educacionais ou pela

\footnotetext{
${ }^{16}$ Projeto Folhas - ação de formação continuada promovida pela SEED do Paraná que visava a construção de materiais didáticos pelos professores, dentre tais livros didáticos públicos.
} 
dificuldade em se construir novos recursos, devido a falta de tempo ou falta de competências digitais complexas que permitam essa criação. Nesse sentido, achamos importante considerar que, neste caso, a autoria docente com o uso de RED não pode ser reduzida apenas à construção do recurso em si, é preciso considerar os diferentes elementos e contextos que foram abordados nos resultados das entrevistas.

\section{Competências Digitais}

Cientes da importância de considerarmos as competências digitais como elemento imprescindível para que os professores tenham condições para criar e adaptar os RED, assim como planejar e desenvolver práticas autorais com os recursos, esta subcategoria se dedica a entender como os docentes percebem as competências digitais, quais as competências eles possuem e quais são as práticas pedagógicas que são realizadas a partir das competências descritas.

Durante a entrevista, ao serem questionados sobre competências digitais, percebeu-se uma dificuldade dos professores em listarem quais competências conseguiram desenvolver que os permitiam construir práticas pedagógicas com os RED. Contudo, a dificuldade em listar as competências seguiu-se de reflexões que demonstravam como o conhecimento sobre a tecnologia em si tinha um papel secundário no uso pedagógico destes recursos.

Temos consciência de que a construção de competências digitais são fundamentais para que os professores consigam aproveitar todo o potencial criativo, comunicacional e pedagógico que estão presentes nas tecnologias digitais. Sabemos, também, que existe uma enorme lacuna entre os níveis de competências necessários para cada atividade, considerando os conhecimentos técnicos de como utilizar as TIC, a compreensão das condições necessárias para utilizar uma tecnologia específica no ensino, e os conhecimentos sobre as possibilidades pedagógicas das TIC (BRASILINO et al., 2018; INSTERFJORD; MUNTHE, 2016). Vejamos como tais questões se apresentam nas falas dos professores:

Principalmente saber navegar na internet. Porque, por exemplo, na minha vivência eu vejo todos os dias professores que não sabem 
fazer uma pesquisa no Google. Tem professores que não acessam ao email, por exemplo (...) Então eu acho assim, saber navegar na internet, saber pesquisar na internet, saber trabalhar com o teu email como mecanismo de comunicação. É essencial saber trabalhar com o celular. Porque hoje com essa geração de alunos que nós temos, o celular é um apêndice deles. Saber também trazer o cunho pedagógico, no momento em que você vai falar: não, agora você vai desligar o celular e vai prestar atenção em mim.

Ametista

É você conhecer a internet, o Google. É você... tem que ler, se dispor a sentar na frente do computador e fazer pesquisa. É tentativa e erro. É você fazer um movimento - faz atividade, não dá certo. Precisa ter tempo, precisa ter o desejo de inovar, de pesquisar.

Jade

Analisando as falas dos professores, percebemos que é valorizado um tipo de competência que tem ligação com o letramento informacional (GASQUE e TESCAROLO, 2010), nesse sentido, a competência digital base, que vai direcionar o surgimento de qualquer outra, é saber como e onde pesquisar e como selecionar as informações mais relevantes em um universo de dados.

De acordo com Gasque e Tescarolo (2010), o sentido de "saber" tem se modificado com o aumento da velocidade em que se produz conhecimento, assim, mais do que lembrar e repetir informação, as pessoas devem ser capazes de encontrá-las e usá-las. Segundo os autores, o letramento informacional corresponde “à estruturação sistêmica de um conjunto de competências que integram as ações de localizar, selecionar, acessar, organizar e gerar conhecimentos, visando à tomada de decisão e à resolução de problemas" (p. 44). Nesse sentido, o professor que tiver o letramento informacional mais desenvolvido terá condições para determinar a extensão das informações necessárias, avaliá-las e relacioná-las com conhecimentos prévios, produzindo novos conhecimentos.

Outra questão levantada ao tratar das competências digitais é a formação e os caminhos utilizados pelos professores para o desenvolvimento de tais 
competências. Vimos, a partir das falas, que em alguns casos são oferecidas pela Secretaria Estadual formações para os professores, o que nem sempre desencadeia efetivamente em melhores práticas com o uso das tecnologias. Isso mostra uma lacuna entre a formação para o uso de TIC e as práticas que são realizadas em sala de aula com a tecnologia. Tal resultado também foi verificado no estudo de Brasilino (2017), em que foi demonstrado que a participação em cursos de formação específica em TIC não apresentou impacto significativo no uso pedagógico das TIC. O segundo ponto trata da aprendizagem de como utilizar as tecnologias com seus colegas, de forma autônoma ou até mesmo com os filhos, como mostram os fragmentos a seguir:

Vejo pouquíssimos professores que estão chegando e sendo criativos. Passam por palestras, por cursos, aperfeiçoamento, formação continuada, mas voltam para a sala com a mesma prática, né?!

Citrino

Eu já compartilhei com muitos colegas, mas nem todos tem o interesse em continuar, porque precisa exatamente do momento de você sentar na frente do computador ou do celular e fazer, pesquisar, procurar, criar, demanda tempo. Muitas vezes as pessoas acham que não vale a pena.

Jade

Eu já fiz curso, mas eu aprendi muito sozinha, com meus filhos, com esse colega, pois esse professor que eu comentei me ajuda muito. Foi com pessoas assim, que conhece um pouco mais e vai dando dicas.

A gente, enquanto professor, vai buscar novos conhecimentos ... você vai, cada vez mais, buscando mais, né?! O que antes era de vez em quando, você tem que refletir que tem que ser mais contínuo.

Jade

Eu fiz um curso na federal que era de TIC. Na nossa secretaria a gente fez vários cursos de formação. Eu já fiz curso de tutoria e também de uso das tecnologias, o uso, por exemplo, do Google 
Drive, da nuvem e outros. Mas eu confesso que é muito difícil você se manter assim... por mais que eu utilize vários recursos hoje, parece, assim, que está muito rápido né?! Você está usando um aplicativo e daqui a pouco tem outro e outros, sabe?!

Diamante

Um último ponto que ainda sobressai em tais falas é a percepção de que por mais que você tenha formação sobre como utilizar as tecnologias, com o passar do tempo e com o surgimento de novas aplicações e novas tecnologias essa formação inclina-se a ficar obsoleta. Nesse sentido, as posições apresentadas pelos docentes tendem a defender que mais importante do que a aprendizagem de como operacionalizar uma tecnologia, é compreender as potencialidades destas no uso pedagógico, como pode-se perceber nas seguintes colocações:

Nem sempre os alunos sabem como utilizar a tecnologia e o professor precisa mediar isso. Eles têm muita informação, só que eles não sabem usar. No momento em que vamos utilizar (TIC), a gente tem que ensinar, explicar, fazer a mediação. Porque muitos não sabem como proceder.

Jade

Tem professores que vão para a sala de aula com o livro didático, com as pastinhas de presença e eles dão show, sabe? E a aula se torna prazerosa. E tem outros que te chamam para ajudar a instalar o notebook: - eu vou passar o vídeo X. E daí você vai e você percebe que é um material bom, você percebe que tem conteúdo, que tem objetivo, mas os alunos estão apáticos... ficam ali... alguns querendo dormir. Então, não adianta você ter o recurso se não associar ele a algo a mais. Porque a tecnologia por si só, só funciona, só é eficaz a partir da minha postura diante dela.

Esmeralda

Porque o fantástico é que a tecnologia em si, ela facilita o trabalho, só que ela é um meio. Então eu estudo com firmeza o conteúdo. Eu tenho que ter o conteúdo para poder utilizar a tecnologia.

Jade 
Percebemos que existe entre os docentes a valorização do pedagógico em detrimento do tecnológico. Nas falas, destacamos o reconhecimento de que os alunos precisam de mediação no uso da tecnologia e isso passa tanto pelo ensino de como utilizar tecnicamente, como pela relação entre o uso daquela tecnologia com a aprendizagem de um conteúdo curricular; que o uso de RED, como exemplificado pelo uso do vídeo, não motiva os alunos se esses usos não estiverem fundamentados em metodologias ou estratégias pedagógicas que produzam sentido na aprendizagem do aluno; e, por fim, o reconhecimento da tecnologia como meio ou ferramenta que auxilia o professor na mediação do conteúdo escolar.

Ao tratar das percepções dos professores sobre as competências digitais que são necessárias para docência, percebe-se que os professores não aprofundam os tipos de competências ou conhecimentos que conseguiram desenvolver ao utilizarem os RED em sua prática pedagógica. Por outro lado, suas falas trazem indícios de que são desenvolvidos usos mais críticos da tecnologia, distanciandose, assim, de um discurso utópico de que o uso da tecnologia por si só garantirá práticas educacionais inovadoras e que promoverá uma aprendizagem mais motivada por parte dos estudantes.

De uma forma geral, a tecnologia é vista ainda como uma ferramenta de suporte ao professor. Não conseguimos identificar, por parte dos professores, a visão da tecnologia como algo integrado às práticas pedagógicas realizadas em sala de aula. Ao contrário, percebe-se uma relação fragmentada, em que a tecnologia é encarada como uma ferramenta a serviço dos procedimentos pedagógicos, ainda que para o desenvolvimento de práticas em que sejam evidentes o processo autoral do professor. Segundo Pischetola e Miranda (2019), uma saída para essa fragmentação é compreender a tecnologia como uma "imersão" na cultura escolar, elemento partícipe da interação ambiente - professor - aluno. Essa visão impele para a construção de uma nova organização escolar que abarque os aspectos materiais, sociais e culturais. Nesse sentido, a integração das TIC no contexto escolar "se dá na relação entre tecnologias, práticas pedagógicas, fatores humanos e sociais, contexto educacional, ou seja, na interação entre objeto e ferramenta tecnológica e o meio ambiente escola" (PISCHETOLA; MIRANDA, 2019, p. 120).

Na figura 18 podemos observar uma síntese dos achados da categoria "relações da autoria docente com as tecnologias". Assim como os resultados das 
outras categorias, elas servirão de base para compor a triangulação dos dados que será abordada no capítulo seguinte, visando responder às questões de estudo desta pesquisa.

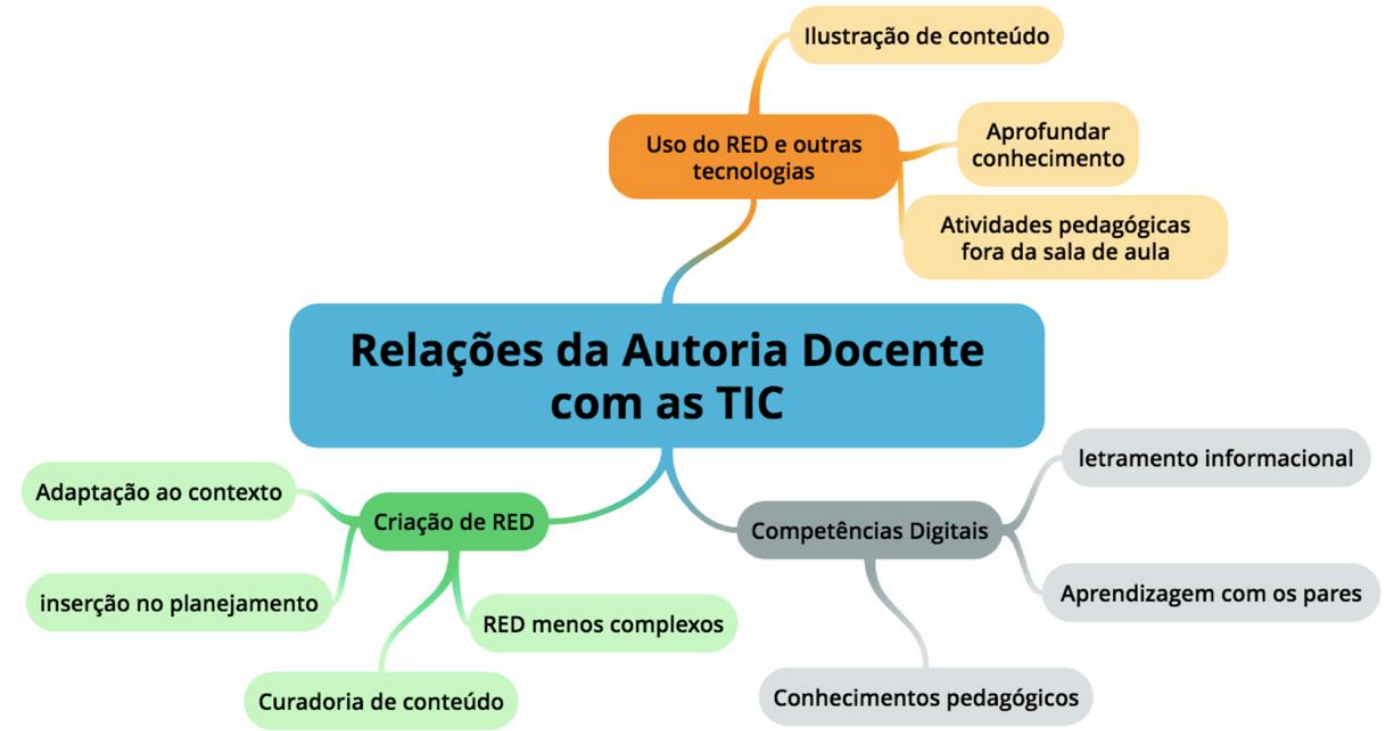

Figura 18 - Resultados da categoria "Relações da Autoria Docente com as Tecnologias". Fonte: Elaboração própria. 


\section{5. \\ Bricolagens instituídas na pesquisa: autoria e práticas docentes com RED}

Este capítulo se propõe a refletir sobre os dados apresentados e discutidos anteriormente, visando a sua triangulação para responder as questões de estudo desta pesquisa. Para tanto, lançaremos mão de uma perspectiva artesanal (MILLS, 1965), no sentido de fazer uma bricolagem entre os resultados, teorias e interpretações possíveis. De acordo com Amado (2010, p. 380):

[...] o investigador qualitativo terá de ser um bricoleur e confeccionador de colchas. Enquanto bricoleur interpretativo, ele produz uma bricolagem - ou seja, um conjunto de representações que traduzem as especificidades de uma situação complexa. No seu papel de confeccionador de colchas, ele costura, edita, reúne pedaços de realidade.

Durante o desenvolvimento desta bricolagem, percebemos como o objetivo da pesquisa de "descrever e compreender se e como os recursos educacionais digitais são utilizados pelos professores para o desenvolvimento de práticas autorais em seus contextos profissionais" está dialogando transversalmente com cada um dos subtópicos abordados. Ao mesmo tempo, usamos a "prática reflexiva" (MERLUCCI, 2005) como guia para a interação entre o pesquisador/sujeitos/contextos/dados da pesquisa no decorrer do capítulo. Segundo Amado (2010), esse fazer se constitui como um desafio, pois envolve a aprendizagem e práticas de concepções e atitudes, que colocam em xeque toda a ideia tradicional e positivista da ciência, fazendo-se necessário uma abordagem complexa e holística.

Nesse sentido, este capítulo ocupa-se das discussões dos resultados, recuperando e respondendo às seguintes questões de investigação: i) Como são utilizados os RED por professores nos seus contextos profissionais? ii) O que motiva os professores a utilizarem os RED nos seus contextos profissionais? iii) Que correlação existe entre o nível de competência digital dos professores e os tipos 
ou modos de utilização de RED? iv) Em que medida o uso de RED contribui para o desenvolvimento de práticas autorais do professor?

\section{1 Utilização dos RED por professores em seus contextos profissionais}

Ao longo da análise dos dados, observamos que os professores utilizam os RED de diferentes formas, e tais usos mudam a depender da concepção que o professor tem sobre o ato de ensinar, sobre como os alunos aprendem e sobre sua visão de como deve ser o processo educacional. Nesse sentido, apontamos que os tipos de usos dos RED podem variar de acordo com a formação pedagógica, didática e metodológica do professor. Assim, é importante para essa reflexão recuperarmos os elementos significativos do trabalho docente e dialogarmos com as práticas levantadas através deste estudo.

Em diversos momentos ao longo da pesquisa nos deparamos com a importância que é dada ao contexto como um dos fatores que influenciam o uso e o tipo de uso que os professores fazem dos recursos educacionais. Se considerarmos o significado da palavra "contexto" veremos que se refere a um "conjunto de circunstância inter-relacionadas de cuja tessitura se depreende determinado fato ou situação" (MICHAELIS, 2020). Assim, entendemos que para que o professor consiga identificar as circunstâncias tecidas ao redor de uma dada situação em sala de aula e que possa intervir no seu fazer educativo é necessário ter consciência da sua prática educacional, e isso pode acontecer através do processo de reflexão sobre a prática.

Sacristán (1995) explica que o conhecimento da prática pedagógica e a possibilidade de a alterar depende da compreensão das interações entre três contextos diferentes, a saber: i) o contexto pedagógico, que é formado pelas práticas cotidianas de sala de aula; ii) o contexto profissional dos professores, que se refere a um modelo de comportamento que envolve ideologias, conhecimentos, crenças e rotinas, produzindo um saber técnico que legitima a prática docente; e iii) contexto sociocultural, que proporciona valores e conteúdos considerados importantes. O entendimento dos contextos apontados por Sacristán nos ajuda a compreender como os RED são utilizados pelos professores participantes do estudo. 
Sobre o contexto tecnológico das escolas, que também compreende o contexto sociocultural, vimos que este se refere aos equipamentos tecnológicos que cada instituição possui, as atividades pedagógicas realizadas com as TIC e a construção e o compartilhamento de trabalho colaborativo entre os professores e a gestão. Quanto à estrutura tecnológica disponível, os dados evidenciaram que em 75,5\% dos casos, as escolas possuíam laboratório de informática, e em 54,1\%, possuíam internet de banda larga. Com relação à frequência de uso de diferentes tipos de tecnologias pelos professores, as mais utilizadas são o celular, onde $84,1 \%$ afirmam usar cotidianamente, e o computador para fins pessoais, com 65,3\% dos professores utilizando todos os dias, seguido pelo uso pedagógico, onde $61,8 \%$ afirma utilizar todos os dias. Nesse sentido, entendemos que os RED são utilizados, em sua maioria, em escolas que possuem minimamente laboratório de informática em funcionamento, dispondo de internet com banda larga, contando com professores que utilizam frequentemente o celular e o computador para fins pessoais e pedagógicos. Tais dados sugerem que estar inserido em um contexto com estrutura tecnológica, e mesmo sendo usuário frequente de diferentes tecnologias, quer no nível pessoal ou profissional, não é uma situação condicionante para que o professor utilize os RED em suas práticas.

Analisando o contexto pedagógico do professor e relacionando-o com os dados daqueles que utilizam RED, vimos que os usos dos recursos digitais se dividem entre aqueles que são utilizados na elaboração do planejamento da aula e os que, durante o planejamento, são criados, adaptados ou ressignificados para serem utilizados com os alunos no contexto de sala de aula.

Os recursos mais procurados e utilizados, conforme indicado pelos professores, foram os planos de aula, vídeos e imagens. Com relação aos usos, $74,2 \%$ dos professores afirmam inserir os RED no seu planejamento, 30\% disseram desenvolver novas estratégias de aprendizagem com os RED, e 23,5\% revelaram fazer adaptações com os recursos diversas vezes em sua prática pedagógica.

Quanto aos usos dos RED e o contexto profissional do professor, observamos que estes usos são diferentes conforme a concepção e ideologias que o professor tem sobre a educação. Sacristán (1995) explica que a profissão docente tem sido constantemente esvaziada, se desdobrando na desprofissionalização do professorado. Entre as consequências, o autor considera que os professores não 
produzem o conhecimento que são chamados a reproduzir, nem determinam as estratégias práticas da ação, sofrendo, ainda, um processo de regulação externa do seu trabalho.

Esse esvaziamento da profissão do professor tem impacto em sua prática de ensino, inclusive nos modos que o docente poderá conceber o uso das TIC integradas ou não ao ensino, e, por extensão, o uso dos RED. Considerando um professor que compreende a sua prática educacional como "transmissão" de conteúdo curricular, pressupomos, a partir da análise dos dados, que ele pode perceber tanto o uso das tecnologias como dos RED como suporte para os conteúdos ou como uma ferramenta que otimiza, ou, ainda, racionalizar o trabalho docente na sala de aula.

De fato, na categoria "aprendizagem" observamos que muitos professores compreendem os RED como uma ferramenta instrucional e instrumental para ilustrar conteúdos. Sob esta ótica, os RED são utilizados para fixar e transmitir conteúdo, sem que isso se relacione a uma reflexão sobre as potencialidades destas tecnologias, seja como uma abordagem metodológica diferenciada ou como uma possibilidade intrínseca às tecnologias no processo de ensino e aprendizagem.

Inclui-se nesta perspectiva a ideia de utilização dos RED para racionalizar a dinâmica de sala de aula, entendendo que o uso de RED contribui para a economicidade do tempo, maior praticidade e organização do trabalho pedagógico, maior alcance dos alunos ou maior agilidade durante o planejamento ou desenvolvimento das aulas.

Ao refletir sobre estes usos dos RED, observamos em tais situações que a tecnologia pode corroborar para o esvaziamento do trabalho docente. Em um contexto profissional em que os professores recebem dada produção pronta, sem condições de escolha e reflexão sobre as estratégias metodológicas utilizadas, muitas vezes reduzidas àquelas explicitadas no livro didático, pode acontecer de o docente sentir/pensar que ele ocupa um papel de quem apenas executa tarefas específicas relacionadas à docência.

Já nos contextos profissionais em que os professores conseguem construir um movimento de reflexão sobre a sua prática pode existir uma tendência de uma percepção diferente da utilização dos RED, como algo mais integrado ao 
planejamento da aula e ao processo de aprendizagem do aluno. $\mathbf{O}$ primeiro elemento que parece ser importante para a mudança de perspectiva do uso dos recursos é a preocupação com a experiência de aprendizagem do aluno.

Tanto os recursos que são utilizados sem modificação quanto aqueles em que o professor realiza algum tipo de adaptação ou ressignificação têm o cuidado com a aprendizagem. Os resultados mostram que as práticas com os recursos estão relacionadas com a crença de que a sua utilização influencia no aumento do interesse do aluno pela aprendizagem do conteúdo, no desenvolvimento de aulas mais dinâmicas e atrativas para o aluno, e a criação de diferentes oportunidades de aprendizagem para que os alunos alcancem seus objetivos educacionais.

Observamos nas falas dos professores que quando o docente reflete sobre a sua prática docente os usos dos recursos educacionais digitais vão além da proposta de suporte ao ensino, ou como um artefato de racionalização da dinâmica de aula. A principal modificação na forma de uso dos RED está no seu uso contextualizado. Nesse sentido, o uso dos RED é planejado como parte da ação do professor para uma determinada aula, e irá se relacionar com os objetivos educacionais, os conteúdos, a metodologia e a avaliação da aprendizagem. Também é no momento do planejamento que os professores pesquisam e selecionam os recursos educacionais que irão compor a atividade de ensino.

Com respeito à contextualização, verifica-se que, ao realizar o planejamento do ensino, esse professor considera o contexto social que a escola e os alunos estão inseridos. Para isso, os RED selecionados precisam ser adaptados para se adequarem a esse contexto, oportunizando melhores condições de aprendizagem. Além disso, existe a percepção de que a modificação de um RED, de acordo com o contexto, propicia a aproximação do recurso à aprendizagem mais significativa para o aluno.

Essa prática de adaptação ocorre tanto quando o professor, ao fazer uma curadoria de RED, pesquisa, seleciona, organiza e modifica, como nos casos em que eles ressignificam, a partir do uso autoral, um artigo, objetos ou mídia em uma nova prática pedagógica, em que tais artefatos passam a ser trabalhados como recurso educacional, e por assim dizer, com intencionalidade pedagógica atrelada ao contexto da escola e do aluno. 
O que irá possibilitar ao professor fazer o uso mais contextualizado e autoral dos RED em sua prática pedagógica é a confiança que tem na experiência, no seu conhecimento pedagógico e em sua autonomia docente. Acreditamos que tais elementos, que fazem parte do desenvolvimento profissional do trabalho docente, podem corroborar para que o professor reflita cotidianamente sobre sua prática, desencadeando na contextualização dos RED, estratégias e conteúdos à realidade da escola e dos alunos.

O quadro 10 sintetiza os tipos de usos que os professores fazem dos RED.

\begin{tabular}{|l|l|}
\hline \multicolumn{1}{|c|}{ Práticas automatizadas } & \multicolumn{1}{c|}{ Práticas contextualizadas } \\
\hline Suporte ao conteúdo & Curadoria de RED \\
\hline Ilustração/ fixação de conteúdos & $\begin{array}{l}\text { RED inserido no planejamento visando } \\
\text { os objetivos, estratégias de ensino e } \\
\text { avaliação da aprendizagem }\end{array}$ \\
\hline $\begin{array}{l}\text { Racionalização da dinâmica de sala de } \\
\text { aula }\end{array}$ & $\begin{array}{l}\text { Adaptação e ressignificação dos RED, } \\
\text { considerando o contexto da escola e } \\
\text { dos alunos }\end{array}$ \\
\hline
\end{tabular}

Quadro 10 - Tipos de usos dos RED. Fonte: Elaboração própria.

\section{2}

\section{Motivação dos professores para a utilização dos RED}

Retomando o conceito do contexto profissional dos professores, vimos que as práticas pedagógicas podem ser diferentes, conforme a concepção de educação do professor e de seu contexto profissional, englobando a gestão pedagógica e as diretrizes da política educacional e curriculares. Do mesmo modo, a motivação para que o professor utilize os RED também pode ser diferente, a depender de como cada um dos atores envolvidos concebem o processo educativo.

Compreendemos que a motivação é um processo básico do ser humano e pode estar relacionado tanto a fatores internos, como externos ao indivíduo. Segundo Ryan e Deci (2000), os tipos de motivações se dividem genericamente 
entre a motivação intrínseca, integrando as razões e atitudes para uma ação que é naturalmente interessante ao sujeito, e a motivação extrínseca, entendidas como as razões externas ao indivíduo para o desenvolvimento de uma ação.

Na questão 19 do questionário, que aborda as atitudes do professor em relação aos RED, observa-se que o uso destes recursos está relacionado com a ideia que o professor tem de conseguir elaborar aulas mais interessantes, promover novas oportunidades de aprendizagem e aumentar a motivação para aprender. Verificouse que $86,9 \%$ dos professores respondentes acreditam que as atividades com os RED influenciam na adoção de novos métodos de ensino, e 78\% destes avaliam que o uso dos RED motiva o docente a repensar a sua prática pedagógica.

Dentre os fatores que podem estar relacionados com a motivação para o uso dos RED, 76,10\% acredita que a experiência prévia com as TIC contribui para que o professor se sinta motivado ao usar tais recursos, e para 57,50\% o tipo de formação pedagógica do professor pode se relacionar com o grau de motivação para esses usos. A relação do tempo de experiência do professor e a utilização de RED teve um menor grau de avaliação positiva, com $40 \%$ dos professores concordando com essa possível relação.

Outros elementos de motivação para o uso de RED foram mapeados na questão aberta. Percebe-se que os professores se sentem motivados a utilizarem os recursos por acreditarem que este uso causa uma influência positiva na aprendizagem do aluno. Entre os resultados alcançados pelos RED, segundo a visão dos professores, estão o desenvolvimento de práticas e estratégias metodológicas que melhoram o processo e o resultado de aprendizagem, sendo essa melhoria da prática docente através do uso do RED um fator motivacional. Também foram citadas a ampliação da experiência da aprendizagem do aluno e o alcance dos objetivos educacionais.

Sobre a relação positiva entre o uso do RED e a melhoria da prática docente, juntamente com a ampliação da experiência de aprendizagem do aluno, os resultados mostraram que pode existir uma contraposição entre as formas de conceber tais fatores motivacionais.

De um lado, nos parece que esse resultado reflete uma visão um pouco utópica e linear sobre os efeitos dos RED no processo de ensino. Neste ponto de 
vista, a simples inserção dos RED em uma atividade educativa teria a capacidade de melhorar a prática docente do professor. Pischetola e Miranda (2019, p. 31) apontam os mitos sobre a tecnologia como um discurso que permeia a educação. Neste cenário, “as tecnologias digitais ocupam um lugar de técnica, tornando-se meios desvinculados do contexto pontual de cada realidade, propiciando um uso sem reflexão e abrindo caminho para uma nova fase do tecnicismo". Do outro lado, temos uma visão um pouco mais situada sobre o uso dos RED no processo de ensino. Nessa visão, os RED são planejados e utilizados, considerando uma abordagem pedagógica que tem o foco na mediação pedagógica do conhecimento e na interação do conhecimento. Neste contexto, o foco não está no uso do RED, mas na forma como ele é pensado em uma proposta pedagógica que abarca desde o planejamento até a avaliação.

Também nos parece existir uma dualidade na percepção do RED quando os professores afirmam que se sentem motivados a utilizar os RED por acreditar que tanto o seu aluno, como a escola estão inseridos na cultura digital. Identificamos que persiste para alguns professores o discurso do aluno como nativo digital. Entre os elementos motivacionais para o seu uso estão a ideia de que o aluno, por já estar imerso em um mundo com tecnologias, teria mais interesse em aulas com a presença de RED, e a obrigação de integrar as tecnologias à escola, visto que ela já se encontra presente em toda a sociedade. Sobre esta perspectiva, Pischetola e Heinsfeld (2018) apontam que existe a ideia generalizada de que os jovens já sabem usar a tecnologia, contudo pesquisas (PISCHETOLA, 2016; BONILLA e PRETTO, 2011; DIAS, 2016; BUZATO, 2010) têm apontado a necessidade da mediação do professor no uso que este aluno faz da tecnologia e, em decorrência, dos RED.

Essa visão também é compartilhada por muitos dos professores que participaram deste estudo. Como parte desta dualidade, que concebe o uso do RED na prática pedagógica, estão os professores que percebem a necessidade de seu trabalho como mediador do aluno com esta tecnologia. O primeiro ponto apresentado pelos docentes é não pressupor que o aluno já conhece, ou sabe como utilizar o artefato tecnológico, mas focar na mediação docente para que ocorra tanto o desenvolvimento de habilidades, como a aprendizagem com o uso da tecnologia. Neste contexto, os professores apontam a necessidade do uso das tecnologias, e dos 
RED por extensão, estarem fundamentados em metodologias e estratégias pedagógicas que produzam sentido na aprendizagem, somente a partir desta fundamentação e contextualização é que poderia ocorrer o maior interesse do aluno pelo uso da tecnologia na sala de aula.

Também se verificou que a busca pelo desenvolvimento profissional do professor - envolvendo as experiências profissionais do docente, seu contexto profissional e engajamento com o mesmo, e a articulação de novos conhecimentos e novas metodologias ao seu repertório pedagógico - é um fator de motivação para a utilização dos RED em sala de aula. Assim, alguns professores consideram que o uso dos RED pode motivá-los a uma reflexão sobre a sua prática, corroborando para mudanças na prática pedagógica. Os dados sugerem que o professor se enxerga como protagonista da alteração de sua prática de ensino, pois defende a ideia que a incorporação das tecnologias ocasionará a mudança de sua prática e, por conseguinte, o maior interesse do aluno em relação à sua disciplina.

Há que se considerar nesta percepção que, embora os docentes aparentem apresentar uma visão acrítica sobre a contribuição dos RED para o seu desenvolvimento profissional, encarando-o como um elemento transformador na sala de aula, percebemos alguns prenúncios em suas falas que podem indicar que o uso da tecnologia pode ser um ponto de partida para o engajamento com o seu crescimento profissional. Em tais casos, verifica-se que os professores, ao assumirem o desafio de integrar os RED em sua prática pedagógica, podem articular novos conhecimentos à sua prática, visto que este desafio de integração abrange sua reflexão sobre a ação e sistematização de novos conhecimentos, quer pedagógicos ou tecnológicos (MAIA, 2017). Nesse sentido, só há desenvolvimento profissional se este for precedido de uma reflexão sobre a prática atual (TARDIF; LESSARD; LAHAYNE, 1991).

Com relação aos fatores motivacionais para as práticas de compartilhamento dos RED, notou-se que a forma de compartilhamento mais realizada é aquela feita entre os pares, chegando a $52 \%$ os respondentes que afirmaram fazer isso muitas vezes. Ao procedermos um estudo de correlação das práticas de compartilhamento, verificamos que existe uma correlação muito forte com a "Atitude relativa aos Recursos Educacionais Digitais". Assim, depreende-se que o professor, ao realizar o compartilhamento de RED, tem a tendência de nutrir uma atitude 
positiva em relação ao uso dos RED na prática de ensino. O mesmo tipo de correlação não foi observado quanto ao uso pessoal ou pedagógico das TIC ou em relação ao seu contexto tecnológico.

O que se pode perceber na análise das entrevistas é que a prática de compartilhamento é realizada principalmente entre os pares de uma mesma instituição, corroborando para o fortalecimento da dimensão coletiva da identidade docente, resultado que dialoga com a pesquisa de Passos et al. (2006). As falas dos docentes sugerem que a atividade de compartilhamento pode ser carregada de diferentes motivações e intenções, a depender do tipo do recurso, se é autoral ou compartilhado de outra fonte.

Em relação aos RED que são pesquisados, utilizados e posteriormente compartilhados com os pares, compreende-se que a motivação para este compartilhamento se associa com o compromisso do educador com a dimensão democrática da educação, sendo apontado pelos mesmos como um "dever" do docente. Esse compromisso com o ato de compartilhar sugere que pode existir uma crença pedagógica de que o conhecimento precisa circular, e, por isso, o desejo ou a necessidade de compartilhar os recursos entre seus colegas de trabalho.

Resultados semelhantes foram encontrados em uma pesquisa sobre motivação para o compartilhamento de REA, em que o compromisso com a dimensão democrática do conhecimento, satisfação em compartilhar as afinidades e atividades pedagógicas, e o compromisso com a expansão do ensino foram fatores motivadores para o compartilhamento que foram identificados (ALGERS e SILVAFLETCHER, 2015).

Com respeito ao compartilhamento de RED autorais, observou-se uma maior reticência nesta atividade. O que foi apresentado é que, em caso de um recurso autoral, pode existir um conflito entre o apego emocional entre a criação do docente e a crença de que o conhecimento precisa ser compartilhado. Acreditamos que esse conflito pode estar ligado às expectativas que os pares têm diante das trocas de recursos e atividades. Percebemos que ainda que seja retratada uma dificuldade do docente em compartilhar, ele o faz, pois parece ter a ideia internalizada de que é "dever" do professor divulgar o conhecimento produzido. Resultados semelhantes foram encontrados na pesquisa de Pirkkalainen et al. (2017), em que se verificou 
que o comportamento de apego a uma criação torna mais dificultoso o ato de compartilhar as práticas pedagógicas e os RED.

Nesse sentido, reconhecemos os seguintes elementos como motivadores para o uso e práticas educacionais com os RED, de acordo com as falas dos docentes:

\section{Elemento de contribuição para o uso dos RED}

- Experiência prévia com a tecnologia.

Fatores motivacionais para o uso e criação de práticas com os RED

- Crença no impacto positivo que os RED podem trazer na aprendizagem do aluno;

- Expectativa de que o uso dos RED contribui para o desenvolvimento de melhores práticas e estratégias metodológicas que podem melhorar o processo e resultados de aprendizagem;

- Ampliação da experiência de aprendizagem dos alunos;

- Crença de que o uso dos RED aproxima a escola à realidade cultural e tecnológica do aluno;

- Confiança de que o uso dos RED contribui para a inserção da escola na "sociedade tecnológica";

- Crença de que o uso dos RED pode contribuir para o engajamento do professor com o seu desenvolvimento proximal;

Fatores motivacionais para o compartilhamento de RED

- Fortalecimento do caráter coletivo da identidade docente;

- Compromisso com a dimensão democrática da educação;

- Consciência de que é uma prática comum e já esperada por grupos de professores; 


\section{3}

\section{Relação entre as competências digitais e os usos dos RED}

Uma das hipóteses que guiou este estudo é que as competências digitais dos professores se associam com as formas de usos dos RED. Nesse sentido, tínhamos como pressuposto que o professor que constrói práticas educacionais com as TIC poderia estar mais inclinado a criar, utilizar e compartilhar os RED.

Nosso entendimento sobre competências digitais no contexto específico da atuação do professor envolve as habilidades individuais do docente para implementar tecnologias em atividades de aprendizagem. O objetivo desse uso de TIC é a melhoria da compreensão do estudante e seu desenvolvimento de conhecimento. Entendemos que essas competências abarcam o conhecimento técnico de como utilizar as TIC, assim como o conhecimento pedagógico que leva à reflexão e compreensão das condições necessárias para utilizar uma tecnologia específica no ensino (INSTERFJORD; MUNTHE, 2016; PETTERSON, 2018).

Com relação às competências digitais dos professores participantes da pesquisa, observou-se que as atividades realizadas mais frequentemente são a utilização da internet para aprender novas metodologias de ensino e a elaboração do planejamento pedagógico. Também se verificou que as atividades que envolvem colaboração, seja por meio do compartilhamento de conteúdos com os pares ou para o desenvolvimento de atividades educativas com os alunos, são desenvolvidas mais frequentemente do que as atividades que envolvem produções midiáticas com os alunos.

De modo geral, a análise dos dados sobre as práticas pedagógicas nos ajuda a inferir que os docentes conseguem desenvolver práticas que demandam competências digitais menos complexas, mas, ao mesmo tempo, parecem ter consciência da relevância da tecnologia em seu fazer educativo e da necessidade de explorá-las para melhorar a sua prática pedagógica.

Ao propormos uma correlação entre as práticas dos professores com as TIC, e as práticas de autoria de RED e de compartilhamento de RED, verificou-se no primeiro caso que existe uma associação moderada entre os professores que desenvolvem atividades educacionais com as TIC com a geração de práticas de autoria de RED. Nesse sentido, vimos que existe possibilidade de que, 
aproximadamente, em $55 \%$ dos casos em que ocorre o uso das TIC na prática pedagógica, também há a possibilidade de ocorrer o desenvolvimento de práticas de autoria de RED. A relação do uso pessoal que os professores fazem das tecnologias com as práticas de autoria de RED também foram consideradas moderadas, apontando a possibilidade de esta relação ocorrer em $49 \%$ dos casos. Desse dado, podemos inferir que para a construção de práticas autorais são necessários o entrelaçamento de outros elementos, além das práticas pedagógicas com o uso da tecnologia, como apontados na subcategoria "práticas de autoria docente".

A mesma classificação de coeficiente não foi verificada na relação com o uso das TIC na gestão pedagógica, que inclui o apoio e incentivo que o professor recebe da gestão para o desenvolvimento de sua prática. Neste caso, observou-se um baixo coeficiente, onde apontava a possibilidade dessa relação acontecer em apenas $32 \%$ dos casos. O que, em nossa interpretação, indica que o fato de a gestão pedagógica apoiar ou estimular o uso da tecnologia em sala de aula não demostra ter grande influência no desenvolvimento de práticas autorais do professor com essa tecnologia.

Com relação às práticas de compartilhamento, vimos que as correlações foram classificadas como baixa ou muito baixa. Isto pode indicar que existe pouca possibilidade da construção de práticas pedagógicas com as TIC, o uso pessoal que estes professores fazem das TIC, ou a relação da gestão pedagógica com as TIC influenciar de algum modo as práticas de compartilhamento de RED que são realizadas pelos professores deste estudo ${ }^{17}$.

Confirmando os dados quantitativos, os resultados da questão aberta reforçam a percepção de que as principais competências digitais desenvolvidas pelos professores estão voltadas para a elaboração do planejamento da aula. Contudo, dessa vez é levantado pelos docentes a percepção de que o uso dos RED colabora para a construção desta competência. Também é citado que inserir os RED

\footnotetext{
${ }^{17}$ É importante ressaltarmos que o estudo de correlação não se traduz em uma relação de causa e efeito. Assim, as correlações classificadas como moderadas não implicam que o professor que constrói práticas pedagógicas com as TIC ou as utiliza em seu cotidiano, irá criar RED em suas atividades pedagógicas. Contudo, acreditamos que este resultado foi um fator importante, pois contribuiu para que, durante as entrevistas realizadas, tivéssemos o cuidado de aprofundar tais questões, de forma a termos elementos mais significativos para refletir e dialogar sobre as competências digitais e as práticas com os RED.
} 
na prática docente pode corroborar para o aumento do conhecimento do professor sobre a tecnologia para o desenvolvimento de estratégias de pesquisa e para a formação continuada.

Resultados semelhantes foram encontrados nas narrativas das entrevistas, fortalecendo os resultados das análises feitas a partir do questionário. Decerto, percebe-se que os professores têm consciência de que é essencial saber como utilizar as tecnologias nas práticas pedagógicas, contudo, existe um cuidado em enfatizar que utilizar as tecnologias só faz sentido se esse uso for contextualizado no planejamento do professor. Assim, apontamos que os dados da entrevista revelam uma posição mais crítica sobre o uso da tecnologia se comparado com os dados oriundos da questão aberta.

Dentre as competências digitais apontadas como necessárias para a criação de práticas educacionais com os RED, os professores refletem sobre importância de se desenvolver o letramento informacional. Neste caso, para trabalhar com os recursos e com outras tecnologias, o professor precisa, primeiramente, saber como realizar pesquisas na internet, como selecionar as informações relevantes, relacioná-las com conhecimentos prévios e construir novos conhecimentos a partir de seus achados. Também é citada a necessidade de saber utilizar as ferramentas de comunicação como email, vídeo conferência e redes sociais.

Com relação aos conhecimentos pedagógicos para uso das tecnologias, os professores tratam da importância de saber como mediar a tecnologia com os alunos, e saber contextualizar o uso do RED ou de outras tecnologias dentro do planejamento, considerando a proposta pedagógica e a metodologia de ensino e a segurança em relação ao conteúdo curricular.

Diferente dos resultados apontados nos dados quantitativos que identificam as práticas que são realizadas com as tecnologias, os dados qualitativos sugerem que, para os professores, as competências digitais são importantes para a prática docente. Contudo, ela não pode ter o mesmo peso das competências pedagógicas, no sentido de saber como planejar, criar estratégias pedagógicas, e mediar o conhecimento e o uso da tecnologia com o aluno.

Buscando responder sobre a relação entre as competências digitais e as práticas com os RED, entendemos, a partir da leitura dos dados, que para os 
professores são necessárias competências menos complexas ligadas ao planejamento, como já discutido em outras pesquisas (BRASILINO, 2017; SILVA, LOUREIRO, PISCHETOLA, 2019; INSTERFJORD e MUNTHE, 2016). Por outro lado, o fato de os professores não saberem identificar com clareza as competências digitais que eles empregam para utilizar os RED em sua prática educacional pode ser justificado pela dificuldade de formar professores para a integração das tecnologias na sua prática, e também pelas questões de falta de infraestrutura e más condições para o trabalho docente.

Decerto, se examinarmos o quadro DigCompEdu, no eixo em que aborda os RED, veremos que são apontadas uma série de competências digitais que precisam ser desenvolvidas pelo professor. Tais competências englobam desde saber como encontrar os recursos, passando pelas competências sobre a criação e modificação de RED, até as competências referentes à gestão, proteção e compartilhamento.

Nesse sentido, ainda que não tenham sido identificados pelo professor como competências digitais, encontramos ao longo da pesquisa elementos que sugerem que o docente:

- sabe como utilizar a internet para encontrar os RED, fazendo uso do letramento informacional;

- cria RED, como apresentações de powerpoint e consegue realizar adaptações de um recurso, considerando o contexto dos alunos e da escola;

- compartilha os RED com os seus pares, especialmente os da mesma instituição.

Assim, entendemos que, em níveis menos complexos, tendo como base quadro DigCompEdu, os professores precisam ter algumas competências digitais desenvolvidas para elaborar práticas pedagógicas com os RED. Contudo, estas competências digitais devem ser compreendidas como parte dos saberes da profissão docente (TARDIF e LESSARD, 2014), considerando que as competências digitais só produzem sentido na prática educacional se estiverem pautadas na reflexão sobre o fazer docente e na autonomia do professor. 


\section{4 \\ Desenvolvimento de práticas autorais do professor e o uso de RED}

No decorrer do estudo tínhamos a intenção de compreender se e como os RED são utilizados para o desenvolvimento de práticas autorais. Nessa altura,interessávamo-nos em saber se a utilização dos RED poderia contribuir para o desenvolvimento da autoria docente, e quais eram as práticas autorais dos professores com os RED. Dessa forma, enxergávamos uma possibilidade de mão dupla entre a autoria docente e os recursos educacionais digitais, no sentido de que o uso dos RED na prática educacional pudesse contribuir para o desenvolvimento da autoria docente, e que, dentre as práticas autorais dos professores, estariam a criação destes recursos digitais.

Para que pudéssemos perceber os liames entre a autoria docente e os RED foi necessário um esforço para compreender o que era autoria docente e como esta se desenvolve na perspectiva e na prática profissional do professor.

Quanto à percepção que os professores têm sobre a autoria, observou-se que faz parte deste conceito a ideia da autoria como uma construção histórica, no sentido de se considerar as leituras, ideias e experiências prévias que são concebidas como pontos de partida para uma nova construção autoral. Percebemos o valor que é dado pelos professores ao enfatizarem a dimensão coletiva da autoria, visto que sugerem que da mesma forma que ela é oriunda de diferentes nós de conhecimento, em que o próprio objeto de criação passa a ter um caráter de continuidade, pois se tornará ponto de partida de outros processos autorais. Esta coletividade apoia que a construção autoral é feita com o outro e para o outro.

Ao investigarmos, por meio do questionário, as práticas autorais que são realizadas com os RED, vimos que poucos foram os professores que afirmaram realizar tais práticas. Entre as citadas estão a criação de estratégias de aprendizagem com os RED, apontada como sendo desenvolvidas frequentemente por 29,3\% dos professores respondentes. Percebe-se que a criação de estratégias de aprendizagem com os RED se relaciona com o uso das TIC no planejamento educacional, discutido anteriormente neste estudo. 
Dentre as outras práticas autorais com os RED estão os reuso de RED em diferentes contextos de aprendizagem, que nesse caso sugere envolver planejamento pedagógico e uma reflexão sobre os objetivos do ensino e o objetivo do RED, sendo uma prática realizada frequentemente por $23,4 \%$ dos docentes. Já a realização de adaptações nos RED é feita de forma constante por $23,5 \%$, e a criação de RED foram empreendidas frequentemente por 22,5\%. Estes resultados apontam que as práticas autorais realizadas com os RED não estão, em sua maioria, relacionadas diretamente com a criação de um novo recurso, mas perpassam por práticas que já são incorporadas ao fazer docente, tais como o planejamento pedagógico, criação de estratégias de ensino e contextualização à realidade do aluno e da escola por meio da adaptação curricular, de materiais pedagógicos ou do planejamento.

Nesse sentido, para compreender se os usos dos RED implicavam no desenvolvimento de práticas autorais foi preciso, antes, mapear as práticas autorais que são realizadas na docência.

A análise indica que a autoria docente não está necessariamente relacionada com a produção de escrita textual, criação de conteúdos ou de materiais didáticos. Antes, compreende uma série de práticas que incorporam o conjunto de saberes da profissão docente (TARDIF e LESSARD, 2014).

Observou-se, na percepção dos professores entrevistados, que a autoria docente é desenvolvida no planejamento de ensino, quando o docente é levado a refletir sobre o seu contexto de trabalho, considerando os objetivos educacionais, os conteúdos, a metodologia e a avaliação. É durante essa prática autoral que o professor pesquisa, seleciona, organiza, adapta ou cria recursos educacionais que serão trabalhados em suas aulas. Reconheceu-se também como processos autorais que ocorrem a partir do planejamento a criação das atividades de ensino, compreendidas como os desdobramentos dados pelo docente das diretrizes e conteúdos curriculares.

O segundo grupo de práticas autorais ocorre no decorrer da aula. Faz parte dos saberes da prática do professor (TARDIF; LESSARD, 2014) entender que o planejamento não é fechado e está sujeito às modificações e adaptações que podem ocorrer no fazer da aula. Assim, é saber do docente que existe na sala de 
aula um espaço para a criação de práticas autorais, que são desenvolvidas pelo professor de acordo com a qualidade das interações que são construídas com os seus alunos. O desenvolvimento desta prática autoral está relacionado com os modos que o professor lida com o seu cotidiano e seu conhecimento sobre a prática, além da segurança que tem sobre os seus conhecimentos pedagógicos e curriculares. Observamos que as falas dos professores sugerem que tais elementos, partes dos saberes da profissão docente, são a base para que eles se sintam seguros em "sair da rota" e criar durante o próprio fazer da aula.

A terceira prática autoral diz respeito à criação e à adaptação de recursos educacionais, considerando o contexto do aluno e da escola. Nesta prática, percebese que o docente faz um trabalho de aproximar um recurso ao contexto específico de aprendizagem do aluno por meio de adaptação e contextualização, configurandose em um processo autoral. A autoria, neste caso, também está presente quando ocorre adaptações dos objetivos de um recurso, modificações da estrutura do RED, e as ressignificações de um objeto midiático em um recurso educacional digital. A adaptação de um RED, pensando na contextualização da aprendizagem é uma prática que também está ligada aos saberes docentes, pois é considerado atributo da autonomia do professor (CONTRERAS, 2010).

Refletindo sobre os elementos da relação entre autoria docente e RED, que emergem a partir dos dados desta pesquisa, principalmente dos dados oriundos das entrevistas aos professores, compreendemos que a utilização de RED não parece influenciar o desenvolvimento de práticas autorais. Contudo, entendemos que o professor que consegue agenciar em sua prática educacional uma bricolagem de fontes e saberes inerente à identidade docente, que se compromete com o seu desenvolvimento profissional e com a construção de um trabalho docente contextualizado poderá desenvolver diferentes processos autorais em sua prática pedagógica.

É sob esta ótica que consideramos importante compreender quais são os fundamentos do percurso profissional e pessoal do docente que contribuíram para que eles se tornassem professores autores. Refletir sobre o caminho formativo destes professores, sobre a concepção de como entendem a autoria e as práticas autorais desenvolvidas no seu cotidiano nos sugere que a autoria docente precisa já estar internalizada na prática do professor para que ele consiga criar 
práticas mais significativas com os RED, proporcionando uma experiência de aprendizagem mais ampliada ao seu aluno.

De certa forma, isso contrapõe um dos resultados da questão aberta que aponta que a utilização dos RED poderia contribuir para o desenvolvimento de competências, ou ainda que o uso de TIC pelos professores poderia provocar alterações na prática de ensino, ocasionando aulas mais atrativas e o aumento do interesse do aluno pelo conteúdo e pela aprendizagem.

Decerto, o que se percebe é que não há uma relação direta de causa e consequência, mas uma relação interdependente. Nesta interdependência, podem existir casos em que o professor que já desenvolve práticas autorais no seu cotidiano consiga se apropriar das tecnologias digitais, de forma a construir um trabalho pedagógico, visando uma aprendizagem mais significativa; e podem existir casos em que o professor, comprometido com o seu desenvolvimento, e a partir das competências digitais que já possui, busque aprender novas metodologias de ensino com as tecnologias, desencadeando em práticas mais autorais.

Ainda assim, com relação à utilização dos RED nas práticas autorais, seja um RED inteiramente criado pelo professor ou adaptado de acordo com o contexto, percebe-se que a concepção sobre os RED que prevalece entre os professores é de uma ferramenta tecnológica integrada à prática docente. Ainda que entre os professores que relataram diferentes práticas autorais com as tecnologias, onde o uso do RED fora planejado, considerando desde o objetivo até a avaliação da aprendizagem, perceba-se que permanecem os usos dos RED como ilustração de conteúdo, ou como uma forma de aprofundar e consolidar o conhecimento.

Neste sentido, parece carecer na visão dos professores o entendimento de que as tecnologias digitais são artefatos culturais do nosso tempo, e que, por isso, estão imersos em um contexto social que corrobora para o desenvolvimento de práticas culturais específicas. Assim, apontamos a necessidade de o professor compreender os RED não com uma ferramenta educacional, mas como um artefato cultural, que, uma vez embutidos de potencialidades comunicacionais e pedagógicas, podem desencadear processos autorais em que não estejam dissociados o conhecimento, a tecnologia, a didática e a metodologia. 


\section{Considerações Conclusivas}

Este estudo teve por objetivo compreender como os recursos educacionais digitais são utilizados pelos professores para o desenvolvimento de práticas autorais. Mas foi possível perceber, no diálogo dos dados com o pesquisador, a literatura e a teoria construída, como esse objetivo inicial foi ampliado, possibilitando pontos de reflexão sobre a construção da autoria docente, as práticas autorais que são criadas pelos professores, as motivações para a utilização dos RED, as práticas e estratégias construídas com os RED, e as competências digitais necessárias para o desenvolvimento de suas práticas, em seus contextos de atuação.

No que concerne aos usos realizados com os RED, a pesquisa apresentou como as práticas que os professores desenvolvem podem estar relacionadas com o tipo de formação pedagógica, didática e metodológica do professor. Este uso tem a possibilidade de se voltar mais para a substituição tecnológica e o esvaziamento da atuação do docente para a sala de aula, ou para a integração das tecnologias de forma mais contextualizada, onde a presença do RED abrange o planejamento, criação de atividades, conteúdos, estratégias metodológicas e avaliação, a partir de um movimento de reflexão e ressignificação de sua prática. Nesse sentido, o professor que integra os RED na sua prática desenvolve a reflexão sobre a ação, e sistematiza novos conhecimentos, tanto didático-pedagógicos, quanto tecnológicos.

Dentre os fatores de motivação para o uso do RED, verificou-se que sua utilização está ligada à crença ou perspectiva que o docente tem de conseguir elaborar aulas mais interessantes e aumentar a motivação do aluno para a aprendizagem. Outro fator relevante é o entendimento que o uso de RED melhora a prática docente e impulsiona o professor para o desenvolvimento de estratégias metodológicas e didáticas, que melhoram o processo e o resultado da aprendizagem.

Por fim, apresentamos a importância da dimensão coletiva da identidade docente, como fator de motivação para o desenvolvimento de práticas com os RED. 
A pesquisa apontou que o compartilhamento de práticas entre os pares é uma atividade que faz parte do cotidiano do professor, e, ao mesmo tempo, é esperada também por eles. Nesse sentido, acredita-se que pode existir uma relação positiva entre a atitude que o professor tem com os RED e com o compartilhamento destes recursos, fortalecendo a ideia de que o professor se desenvolve profissionalmente, também a partir das trocas colegas.

Com respeito à autoria docente, observou-se que a percepção que os docentes têm sobre a autoria não se relaciona apenas com a criação original. Embora a noção da originalidade permaneça em suas falas, existe um consenso de que ela é, na verdade, uma construção histórica de releituras e diferentes pontos de partida.

Uma segunda noção importante para a construção deste conceito é que a autoria pode ser compreendida como um ponto de inovação ao que é posto antes. Nesse caso, a autoria não é algo absolutamente novo, mas aquilo que é inédito em termos de práticas ou criações do professor. $O$ inédito emerge a partir da interação do sujeito professor, com as múltiplas dimensões do seu contexto de trabalho, tais como o currículo oficial, ideias pré-concebidas, experiências, recursos prontos, e etc.

Em relação às práticas autorais, percebemos que elas podem ser desenvolvidas no planejamento de ensino, pois é a partir do ato de planejar que o docente pode refletir sobre o seu contexto de trabalho, escolhendo a melhor estratégia metodológica e didática para o alcance dos objetivos educacionais. Também é durante este processo que o professor se vale de seu letramento informacional para pesquisar, selecionar e organizar os recursos, e por vezes, adaptar ou criar novos recursos que serão trabalhados em suas aulas.

Além do planejamento, as práticas autorais também ocorrem na sala de aula. Cabe nessa interpretação que o planejamento criado pelo professor não se encerra em si mesmo, visto que precisa estar aberto às modificações e adaptações que podem ocorrer durante o fazer da sala de aula, sendo a improvisação do professor um conceito-chave para que emerja a autoria docente durante a aula. 
A terceira prática autoral diz respeito à criação e adaptação dos recursos educacionais, considerando o contexto do aluno e da escola. Nesse sentido, o professor ressignifica recursos educacionais, objetivos, conteúdos, estratégias e avaliações a um contexto específico de aprendizagem.

A pesquisa revelou que mesmo entre os professores autores, não é comum a criação de RED, se considerarmos a criação original. As práticas de criação de RED estão mais voltadas à adaptação para o contexto de aprendizagem do aluno, à criação de estratégias para utilização do RED, e à ressiginificação de um RED, criando ou adaptando os objetivos educacionais, em um planejamento pedagógico.

Ao compararmos os resultados de todos os respondentes dos questionários com os resultados dos professores que aceitaram participar das entrevistas, o que se percebe é que poucos foram considerados autores de RED. De um total de 257 sujeitos, apenas 21 docentes se encaixaram na perspectiva de professor-autor, o que, por sua vez, revela que existe um gap entre os professores autores e professores usuários de recursos educacionais e outras tecnologias.

Nesse sentido, a utilização de RED e de outras tecnologias nem sempre está ligada ao desenvolvimento de estratégias pedagógicas ressignificadas e contextualizadas para o aluno. $\mathrm{O}$ que se percebeu muitas vezes foi a permanência da visão instrumental dos RED, como uma ferramenta de suporte ao professor, ou para a fixação e ilustração de conteúdos. As falas dos docentes sugerem que este discurso acrítico dos RED é tão difundido e aceito pelos educadores, que persiste até mesmo entre os professores que desenvolvem práticas autorais com os RED.

Embora, por vezes, os professores assumam em seus falas que os RED são concebidos como ferramentas tecnológicas para aprendizagem, entendemos que as práticas autorais que conseguem desenvolver com os RED indicam uma visão da educação que não corresponde a um modelo prescritivo e fragmentado do processo educativo. Neste caso, acreditamos que tais práticas poderiam sugerir uma proposta educacional, em que exista maior ligação entre os elementos que constituem a dinâmica escolar. Nesse sentido, os RED estariam interligados desde o planejamento, passando pelos conteúdos, atividades em sala de aula e avaliação da 
aprendizagem, uma proposta mais orgânica e contextualizada com o uso da tecnologia.

A dificuldade em relacionar o uso de RED com o desenvolvimento de práticas autorais com os RED ficou mais evidente nos cálculos de correlação, considerando os baixos índices de correlação presentes entre os diferentes construtos criados. Tanto os resultados oriundos dos dados quantitativos, quanto os oriundos das entrevistas, sugerem que a utilização de RED não parece influenciar o desenvolvimento de práticas autorais, mas o professor precisa já ter a autoria docente internalizada em seu fazer educativo, para que ele consiga criar práticas mais significativas com os RED. Decerto, o que irá possibilitar ao professor fazer uso mais contextualizado e autoral dos RED em sua prática pedagógica é a confiança que tem na sua experiência, no seu conhecimento pedagógico e em sua autonomia docente.

Quanto às nossas recomendações para a construção de práticas autorais com os RED, defendemos que:

- É preciso desconstruir o conceito da autoria como algo original ou derivado da genialidade do sujeito. A autoria é um fenômeno coletivo, que se constrói a partir das experências anteriores, de leituras prévias e da interação com os pares.

- A autoria docente não se refere apenas ao professor que cria recursos ou produz conteúdo. Ela está presente na prática do planejamento, no espaço para a improvisação em sala de aula, na adaptação e ressignificação de recursos, conteúdos e estratégias de ensino. Nesse sentido, é importante que o professor se reconheça como autor ao desenvolver essas práticas, que muitas vezes já fazem parte do cotidiano do docente, e o levam a refletir sobre o seu fazer educativo e se desenvolve profissionalmente.

- É necessário romper com a ideia de que o uso do RED e de tecnologias na sala de aula produz, por si só, melhoria da prática docente e aumento da motivação do aluno para a aprendizagem. Este uso, com vista a influenciar tais resultados, precisa estar pautado em uma abordagem pedagógicas que permita que a tecnologia seja pensada em conjunto com toda a prática educativa. Assim, a prática educacional precisa se afastar da visão 
fragmentada do processo de ensino que concebe os RED como ferramenta tecnológica para o suporte, ilustração e fixação de conteúdos.

- Ainda que seja sabido que a utilização de RED e de outras tecnologias não estejam relacionados diretamente ao desenvolvimento de práticas autorais, defendemos que a integração destes na prática docente, a depender da epistemogia educacional do professor, pode contribuir para que ele repense sua metodologia e busque novas possibilidades pedagógicas visando alterar sua prática. Nesse sentido, o movimento de desenvolvimento profissional a partir e através da tecnologia, pode sugerir potencialidade para que o professor consiga desenvolver práticas mais autorais.

A seguir, apresentamos alguns fatores limitantes da pesquisa, assim como perspectivas futuras de estudo.

Com relação aos fatores limitantes, acreditamos que a elaboração do questionário poderia ser aprimorada. Em uma nova versão acrescentaríamos cinco pontos na escala de Likert, a opção "não se aplica" como uma das respostas possíveis, e transformaríamos algumas perguntas como obrigatórias. Acreditamos que o número de falta de respostas para alguns dos itens poderia ser reduzidos com essas alterações no questionário.

A indisponibilidade dos professores para a participação nos grupos focais nos obrigou a repensar o caminho metodológico para a coleta de dados, nesse sentido, acreditamos que a realização do grupo focal poderia trazer resultados mais apronfundados, considerando que seria fruto da discussão entre os professores.

Com respeito aos desdobramentos da tese, julgamos que o tema da autoria docente ainda precisa ser aprofundado. Faz-se necessário entrevistar mais professores, em distintos níveis e/ou modalidades, buscando mapear outras práticas autorais. De posse destes novos achados, analisados sob a ótica dos nossos referenciais, poder-se-ia consolidar ainda mais a teoria da autoria docente que ora iniciamos.

Outrossim, acreditamos também ser necessário a ampliação da análise de como as tecnologias são integradas nas práticas autorais, para além dos usos com os RED. Assim, precisaríamos revisitar o tema das competências digitais com base 
na realidade do professor, principalmente considerando a sua experiência com a tecnologia e o contexto tecnológico em que está inserido.

Espera-se que esse estudo possa contribuir para o campo da pesquisa educacional, instigando a ampliação do debate por ajudar a ampliar o debate sobre a autoria docente e sobre as práticas contextualizadas com os recursos educacionais digitais. 


\section{Referências bibliográficas}

ABREU, N; BALDANZA, R; GONDIM, S. Os grupos focais online : das reflexões conceituais à aplicação em ambiente virtual. Revista de Gestão da Tecnologia e Sistemas de Informação, v. 6, n. 1, 2009. Disponível em: $<$ http://dx.doi.org/10.4301/S1807-. Acesso em 28 de março de 2019.

AMADO, J.; FREIRE, I. Estudo de caso na investigação em educação. In AMADO, J. Manual de Investigação Qualitativa em Educação. Coimbra: Impressa da Universidade de Coimbra, 2013.

AMARAL, Mirian. Autoria docente e discente: pilares de sustentabilidade na produção textual imagética em redes educativas presenciais e online. Tese (Doutorado em Educação e Cultura Contemporânea) - Programa de Pós-Graduação em Educação, Universidade Estácio de Sá, Rio de Janeiro, 2014.

AMIEL, T. Educação aberta: configurando ambientes, práticas e recursos educacionais. In SANTANA, B.; ROSSINI, C.; PRETTO, N. (orgs.) Recursos Educacionais Abertos: práticas colaborativas política pública. Salvador: Edufba; São Paulo: Casa da Cultura Digital, 2012.

AL KHATEEB, A. Measuring Digital Competence and ICT Literacy: An Exploratory Study of In-Service English Language Teachers in the Context of Saudi Arabia. International Education Studies, v. 10, n. 12, 2017. Doi: https://doi.org/10.5539/ies.v10n12p38. Acesso em 18 de outubro de 2018.

ALGERS, A.; SILVA-FLETCHER, A. Teachers' Perceived Value, Motivations for and Adoption of Open Educational Resources in Animal and Food Sciences. International Journal of Emerging Technologies in Learning (iJET), v. 10, n.2, 2015. http://dx.doi.org/10.3991/ijet.v10i2.4427. Acesso em 18 de outubro de 2018 .

ALENCAR, E. M. L. S. Criatividade. Brasília: Editora Universidade de Brasília, 1995

AGUIAR, Eliane. Escrita, autoria e ensino: um diálogo necessário para pensar a constituição do sujeito-autor no contexto escolar. Tese (Doutorado em Educação) - Faculdade de Educação, Universidade de São Paulo, São Paulo, 2010.

ATENAS, J. e HAVEMANN, L. Questions of quality in repositories of open educational resources: a literature review. Research in Learning Technology, $v$. 22, 2014. Acesso em 20 de outubro de 2018.

BAGETTI, S; MUSSOI, E.; MALLMANN, E. Fluência tecnológica-pedagógica na produção de recursos educacionais abertos (REA). Rev. Texto livre, v. 10, n. 2, 2017. DOI: 10.17851/1983-3652.10.2.185-205. Acesso em 13 de outubro de 2018.

BANNELL, R. Et al. Educação no século XXI: cognição, tecnologias e aprendizagens. Petrópolis/Rio de Janeiro: Vozes/Editora PUC, 2016. 
BARDIN, L. Análise de Conteúdo. Lisboa, Portugal; Edições 70, 1977.

BARRETO, R. Tecnologias na educação brasileira: de contexto em contexto. Rev. Educação e Cultura Contemporânea, v. 16, n. 43, p. 218-234, 2019. Disponível em ://DX.DOI.ORG/ 10.5935/2238-1279.20190011. Acesso em: 23 de novembro de 2019.

BARTHES, Roland. O rumor da língua. $2^{\mathrm{a}}$ ed. São Paulo: Ed. Martins Fontes, 2004

BASNIAK, M. Políticas de tecnologia na educação: o programa Paraná Digital. 2014. 210 f. Tese de doutorado, Universidade Federal do Paraná, Curitiba, 2014.

BAUER, M. Análise de conteúdo clássica: uma revisão. In BAUER, M. Pesquisa qualitativa com texto, imagem e som. Petrópolis: Editora Vozes, 2003.

BEAVEN, T. Use and Reuse of OER: professional conversations with language teachers. Journal of e-Learning and Knowledge Society Vol. 9, n. 1, 2013. Disponível em: http://oro.open.ac.uk/36500/. Acesso em 18 de novembro de 2018.

BELL, J. Como realizar um projecto de investigação : um guia para a pesquisa em ciências sociais e da educação. Lisboa: Gradiva, 1997.

BENALI, M; KADDOURI, M; AZZIMANI, T. Digital competence of Moroccan teachers of English. International Journal of Education and Development using Information and Communication Technology (IJEDICT), v. 14, n. 2, 2018. Disponível em: https://files.eric.ed.gov/fulltext/EJ1190022.pdf. Acesso em 02 de novembro de 2018.

BENNET, Andrew. The Author. In Bennet, A. Royle N. An Introduction to literature, criticism and theory. $3^{\circ}$ ed. Great Britain: Person Educational Limited, 2004.

BENKLER, Y. La riqueza de las redes: Cómo la producción social transforma los mercados y la libertad. Barcelona: Icaria, 2015.

BENNETT, L; SEGERBERG, Al. The Logic of Connective Action. Cambridge University Press, 2013.

BLAU, I; SHAMIR-INBAL, T. Digital competences and long-term ICT integration in school culture: The perspective of elementar school leaders. Education Information Technologies, vol.22, 2017. Disponível em: DOI 10.1007/s10639-015-9456-7. Acesso em 25 de novembro de 2018.

BLISS, T et al. An OER COUP: College Teacher and Student Perceptions of Open Educational Resources. Journal of Interactive Media in Education, 2013(1). Disponível em: http://doi.org/10.5334/2013-04. Acesso em 19 de novembro de 2018.

BLOMGREN, C. OER Awareness and Use: The Affinity Between Higher Education and K-12. International Review of Research in Open and Distributed Learning, $\quad$ v. $19, \quad$ n. 2 , 2018. Disponível em: http://www.irrodl.org/index.php/irrodl/article/view/3431/4584. Acesso em $18 \mathrm{de}$ novembro de 2018.

BRANCO, E.; CANTINI, M.; MENTA, E. Investigando o uso de tecnologias nas escolas públicas estaduais do Paraná. X Congresso Nacional de Educação (EDUCERE), 2011. Disponível em: 
http://portaldoprofessor.mec.gov.br/storage/materiais/0000016199.pdf. Acesso em 12 de novembro de 2018.

BRASIL. Relatório do $2^{\circ}$ Ciclo de Monitoramento das Metas do Plano Nacional de Educação - 2018. - Brasília, DF: Inep, 2018. Disponível em: http://portal.inep.gov.br/documents/186968/485745/RELATÓRIO+DO+SEGUN DO+CICLO+DE+MONITORAMENTO+DAS+METAS+DO+PNE+2018/9a0398 77-34a5-4e6a-bcfd-ce93936d7e60?version=1.17. Acesso em 18 de novembro de 2019.

BRASIL. Ministério da Educação. Base Nacional Comum Curricular Documento preliminar. MEC. Brasília, DF, 2015. Disponível em: http://basenacionalcomum.mec.gov.br. Acesso em 20 de janeiro de 2019.

BRASIL. Lei no 13.005, de 25 de junho de 2014. Aprova o Plano Nacional de Educação (PNE) e dá outras providências. Diário Oficial da União [da] República Federativa do Brasil, Brasília, 2014. Disponível em: http://portal.inep.gov.br/documents/186968/485745/Plano+Nacional+de+Educaçã o+PNE+2014-2024++Linha+de+Base/c2dd0faa-7227-40ee-a520-

12c6fc77700f?version=1.1. Acesso em 20 de janeiro de 2019 .

BRASILINO, A. Formação de professores e a prática pedagógica com tecnologias: estudo da correlação na base TIC Educação 2014. 2017. 166 f. Dissertação de mestrado em Educação. Pontifícia Universidade Católica do Rio de Janeiro, RJ, 2017.

BRASILINO, A.; PISCHETOLA, M.; COIMBRA, C. Formação docente e letramento digital: Uma análise de correlação na base da pesquisa TIC Educação. In CETIC. (2018). Pesquisa sobre o uso das tecnologias de informação e comunicação nas escolas brasileiras: TIC educação 2017. [livro eletrônico]. 1. Ed. São Paulo: Comitê Gestor da Internet no Brasil, 2018.

BRANCO, S. A lei autoral brasileira como elemento de restrição à eficácia do direito humano à educação. Rev. Internacional de Direitos Humanos, n. 6, ano 4, 2007.

BRYMAN, A. Social research methods. Oxford University Press: New York, 2012.

BONILLA, M.; PRETTO, N. Movimentos colaborativos, tecnologias digitais e educação. Rev. Em Aberto, Brasília, v. 28, n. 94, 2015. Disponível em: http://portal.inep.gov.br/documents. Acesso em 20 de janeiro de 2019.

BORTHWICK, K.; DICKENS, A. The Community Café: creating and sharing open educational resources with community-based language teachers. Journal of e-Learning and Knowledge Society, v.9, n.1, 2013. Disponível em: http://www.je-lks.org/ojs/index.php/Je-LKS_EN/article/viewFile/803/793. Acesso em 20 de outurbo de 2019.

BOYD, D. e CRAWFORD, K. Critical Question for Big Data. Information, Communication and Society, 2012.

BUCKINGHAM, D. Cultura digital, educação midiática e o lugar da escolarização. Rev. Educação e Realidade, v. 35, n.3, 2010. Disponível em: https://www.redalyc.org/html/3172/317227078004/. Acesso em 20 de janeiro de 2017. 
BUTCHER, N. A Basic Guide to Open Educational Resources (OER). Commonwealth of Learning, 2011. Disponível em: http://unesdoc.unesco.org/images/0021/002158/215804e.pdf. Acesso em 14 de abril de 2019.

BUZATO, M. Cultura Digital e apropriação ascendente. Apontamentos para uma educação 2.0. Educação em Revista: Belo Horizonte, 2010. http://www.scielo.br/scielo.php?pid=S010246982010000300014\&script=sci_abstr act\&tlng=pt. Acesso em 20 de outubro de 2017.

CASTELLS, M. A sociedade em rede. São Paulo: Paz e Terra, 1999.

CASTRO, C. A utilização de recursos educativos digitais no processo de ensinar e aprender: práticas dos professores e perspetivas dos especialistas. 2014. 414 f. Tese de doutorado. Universidade Católica Portuguesa, Porto, 2014.

CASTRO, E., MELO, K. S., e CAMPOS, G. H. B. Afetividade e motivação na docência online: um estudo de caso. RIED. Revista Iberoamericana de Educación a Distancia, $21 \quad$ (1), 2018. Disponível em: http://dx.doi.org/10.5944/ried.21.1.17415. Acesso em: 12 de dezembro 2019

CASTRO-FILHO, J. et al. Quando objetos digitais são efetivamente para aprendizagem: o caso da matemática. In: Anais ..., 2008. Disponível em: http://www.br-ie.org/pub/index.php/sbie/article/view/747. Acesso em 21 de abril de 2019.

CELLARD, A. A análise documental. In: POUPART, J. et al. A pesquisa qualitativa: enfoques epistemológicos e metodológicos. Petrópolis, Vozes, 2008.

CETIC. Pesquisa sobre o uso das tecnologias de informação e comunicação nas escolas brasileiras: TIC Educação 2013 [livro eletrônico]. 1. ed. - - São Paulo : Comitê Gestor da Internet no Brasil, 2014. Disponível em: http://www.cetic.br/media/docs/publicacoes/2/tic-educacao-2013.pdf. Acesso em 15 de setembro de 2016.

CETIC. Pesquisa sobre o uso das tecnologias de informação e comunicação nas escolas brasileiras: TIC Educação 2014 [livro eletrônico]. 1. ed. - - São Paulo: Comitê Gestor da Internet no Brasil, 2015. Disponível em: http://www.cetic.br/media/docs/publicacoes/2/tic-educacao-2013.pdf. Acesso em 15 de setembro de 2016.

CETIC. Pesquisa sobre o uso das tecnologias de informação e comunicação nas escolas brasileiras: TIC Educação 2015 [livro eletrônico]. 1. ed. - - São Paulo: Comitê Gestor da Internet no Brasil, 2016. Disponível em: http://www.cetic.br/media/docs/publicacoes/2/tic-educacao-2013.pdf. Acesso em 02 de setembro de 2018.

CLEMENTS, K.; PAWLOWSKI, J. User-oriented quality for OER: understanding teachers' views on re-use, quality, and trust. Journal of Computer Assisted Learning,n. 28, 2012. Doi: 10.1111/j.1365-2729.2011.00450.x. Acesso em 15 de fevereiro de 2018.

CRESWELL, J. Educational research: Planning, conducting, and evaluating quantitative and qualitative research. 4 ed. Boston, MA: Pearson, 2012.

CONTRERAS, J. Ser y saber en la formación didáctica del profesorado: una visión personal. Revista Interuniversitaria de Formación del Profesorado. 
Zaragoza:

2010.

Disponível

em:

http://www.redalyc.org/articulo.oa? $\mathrm{id}=27419198004$. Acesso em 24 de outubro 2019

CONTRERAS, J. A autonomia de professores. $2^{\mathrm{a}}$ ed. São Paulo: Editora Cortez, 2012.

COSTA, A.; AMADO, J. Análise de conteúdo suportada por software. Aveiro: Ludomedia, 2018.

COSTA, A.; REIS, L. Vantagens e desvantagens do uso de software na análise de dados qualitativos. Revista Ibérica de Sistemas e Tecnologias de Informação, v. 23, 2017. Disponível em: http://www.scielo.mec.pt/scielo.php?script=sci_arttext\&pid=S164698952017000300001. Acesso em 15 de setembro de 2016.

DAY, C. O desenvolvimento profissional dos professores em tempos de mudanças e os desafios para as universidades. Revista de Estudos Curriculares, v.1, p.151-188, 2003. Acesso em 15 de agosto e 2018.

DENZIN, N; LINCOLN, Y. Introdução. A disciplina e a prática da pesquisa qualitativa. In Denzin, N. O planejamento da pesquisa qualitativa: teorias e abordagens. Porto Alegre: Artmed, 2006.

DIAS, L. Multiletramentos na sala de aula: entre a intuição e a intencionalidade. 2016. 101 f. Dissertação de mestrado. Pontifícia Universidade Católica do Rio de Janeiro, Rio de Janeiro, 2016.

DIAS, W. Há espaço para a construção autoral nos trabalhos de pesquisa escolar. Tese (Doutorado em Educação) - Departamento de Educação, Pontfícia Universidade Católica do Rio de Janeiro, Rio de Janeiro, 2017.

DUFFY, B. Análise de dados documentais. In BELL, J. Como realizar um projecto de investigação (pp. 90-98). Lisboa: Gradiva, 1997.

DUARTE, T. 2009. A possibilidade da investigação a 3: reflexões sobre triangulação (metodológica). Cies e-working paper. Centro de Investigação e Estudos de Sociologia. Disponível em: http:// www.cies.iscte.pt/destaques/documents/CIES-WP60_Duarte_003.pdf. Acesso em 11 de dezembro de 2018.

DUARTE, L., VIRIATO, E. Análise das políticas de formação continuada no estado do Paraná (2003 - 2010): algumas proposições. SEMINÁRIO DE PESQUISA EM EDUCAÇÃO NA REGIÃO SUL, 2012. Anais...Caxias do Sul: Universidade de Caxias do Sul, 2012. Acesso em 03 de dezembro de 2019.

ECHALAR, A.; PEIXOTO, J. Programa Um Computador por Aluno: o acesso às tecnologias digitais como estratégias para a redução das desigualdades sociais. Rev. Avaliação e políticas públicas educacionais. v. 25, n. 95, p. 393-413, 2017. Disponível em: https://10.1590/S0104-40362017002501155. Último acesso em 20 de outubro de 2019.

ECO, H. Apocalípticos e Integrados. São Paulo, Perspectivas, 1979.

FERNÁNDEZ, J.; PÉREZ, K. Nuevos escenarios y competencias digitales docente: hacia la profesionalización docente com TIC. Revista de currículum e formación del professorado. Vol. 22, $\mathrm{n}^{\mathbf{0}}$ 1, 2018. Disponível em: 
https://recyt.fecyt.es/index.php/profesorado/article/view/63620. Acesso em $15 \mathrm{de}$ setembro de 2019.

FERRARI, A. Digital Competence in Practice: An Analysis of Frameworks.Joint Research Centre of the European Commission, 2012. Disponível em: http://jiscdesignstudio.pbworks.com/w/file/fetch/55823162/FinalCSReport_PDFP ARAWEB.pdf. Acesso em 11 de maio de 2019.

FIALHO, N. Formação docente por meio do desenvolvimento de Recursos Educacionais Abertos para o ensino de química. Tese (Doutorado em Educação) - Departamento de Educação, Pontifícia Universidade Católica do Paraná, Curitiba, 2016

FIGUEIREDO FILHO, D.; SILVA Jr, J. Desvendando os Mistérios do Coeficiente de Correlação de Pearson (r). Revista Política Hoje, Vol. 18, n. 1, $2009 . \quad$ Disponível em: https://periodicos.ufpe.br/revistas/politicahoje/article/viewFile/3852/3156. Acesso em 11 de janeiro de 2019.

FORTUNATO, M. Autoria e aprendizagem da escrita. Tese (Doutorado em Educação) - Faculdade de Educação, Universidade de São Paulo, São Paulo, 2009.

FOUCAULT, M. Ditos e Escritos: Estética - literatura e pintura, música e cinema (vol III). Rio de Janeiro Forense Universitária, 2001.

FUCHS, G. O funcionamento da autoria na escrita coletiva de estudantes de ensino médio inovador: espaço de negociação. Tese (Doutorado em Ciências da Linguagem) - Universidade do Sul de Santa Catarina, Tubarão, 2016.

GARCIA-PENALVO, F. et al. Open knowledge: challenges and facts. Online Information Review, 34, 4, 520 - 539, 2010.

GASQUE, K., TESCAROLO, R. Desafios para implementar o letramento informacional na educação básica. Educação em Revista, v.26, n.1. Disponível em http://dx.doi.org/10.1590/S0102-46982010000100003. Acesso em 18 de dezembro de 2019.

GATTI, B. Grupo focal na pesquisa em ciências sociais e humanas. Brasília: Líber Livro. 2012.

GIL, Antonio. Métodos e técnicas de pesquisa social. 6 ed. São Paulo: Atlas, 2008.

GONDIM, S. Grupos focais como técnica de investigação qualitativa: desafios metodológicos. Paidéia, v. 12, n. 24, 2002. Disponível em: $\leq \mathrm{http}$ //dx.doi.org/10.1590/S0103-863X2002000300004>. Acesso em 7 de fevereiro de 2017

GUACANEME- MAHECHA, M.; ZAMBRANO-IZQUIERDO, D.; GOMEZZEREMEÑO, M. G. Apropiación tecnológica de los profesores: el uso de recursos educativos abiertos. Educ. Educ., v. 19, n. 1, 2016. DOI: 10.5294/edu.2016.19.1.6. Acesso em 11 de abril de 2019.

GUDMUNDSDOTTIR, G.; HATLEVIK, O. Newly qualified teachers' professional digital competence: implications for teacher education. European Journal of Teacher Education, 41:2, 214-231, 2018. Disponível em: https://doi.org/10.1080/02619768.2017.1416085. Acesso em 13 de abril de 2019. 
HADJERROUIT, S. Developing Web-Based Learning Resources in School Education: A User-Centered Approach. Interdisciplinary Journal of Knowledge and Learning Objects, v.6, 2010. Acesso em 09 de abril de 2018.

HALMANN, Adriane. Autoria de conteúdos digitais por professores em formação: potencialidades para apropriações científico-metodológica. Tese (Doutorado em Educação) - Faculdade de Educação, Universidade Federal da Bahia, Salvador, 2011)

HARRIS, J. One to One Technology and its Effect on Student Academic Achievement and Motivation. Contemporary Educational, v. 7, n. 4, 2016. Disponível em: https://www.learntechlib.org/primary/p/150906/. Acesso em $11 \mathrm{de}$ março de 2019.

HEINSFELD, B. Conhecimento e tecnologia: uma análise do discurso das Políticas Públicas em educação. 2018. 119 f. Dissertação de Mestrado, Pontifícia Universidade Católica do Rio de Janeiro, Rio de Janeiro, 2018.

HILL, M; HILL, A. Investigação por questionário. Lisboa: Edições sílabo, 2012.

HILTON III, J. et al. The four 'R's of openness and ALMS analysis: frameworks for open educational resources. Open Learning, v. 25, n. 1, 2010. Acesso em 10 de março de 2019.

HILTON III, J.; WILEY, D.; LUTZ, N. Examining the Reuse of Open Textbooks. The International Review of Research in Open and Distance Learning, v. 13, n. 2, 2012. Acesso em 14 de junho de 2019.

HUGUES, J; MACKENNA, C. The impact of developing Open Educational Resources (OERs) on novice OER developers. Journal of interactive media in education, 2012(2). DOI: http://doi.org/10.5334/2012-14. Acesso em 24 de março de 2019.

HUNG, C. Et al. The benefits of a challenge: student motivation and flow experience in tablet-PC-game-based learning. Interactive Learning Environments, v. 23, n. 2, 2015. Disponível em: http://dx.doi.org/10.1080/10494820.2014.997248. Acesso em 11 de março de 2019.

INSTEFJORD, E.; MUNTHE, E. Preparing pre-service teachers to integrate technology: an analysis of the emphasis on digital competence in teacher education curricula. European Journal of Teacher Education, 39:1, 77-93, 2016. Disponível

em: https://www.tandfonline.com/doi/abs/10.1080/02619768.2015.1100602. Acesso em 11 de março de 2018.

JACQUES, Juliana. Performance docente na (co) autoria de Recursos Educacionais Abertos (REA) no ensino superior: atos éticos e estéticos. Tese (Doutorado em Educação) - Faculdade de Educação, Universidade Federal de Santa Maria, Santa Maria, 2017.

JENKINS, H. Confronting the Challenges of Participatory Culture: Media Education for the 21st Century, White Paper for MacArthur Foundation, 2006.

JEONG, H.; HMELO-SILVER, C. Productive use of learning resources in an online problem-based learning environment. Computers in Human Behavior, n, 26, $\quad$ p. $\quad 84-99, \quad 2010 . \quad$ Disponível em 
www.sciencedirect.com/science/article/pii/S074756320900123X. Acesso em 26 de novembro de 2019.

KWAK, S. How Korean Language Arts Teachers Adopt and Adapt Open Educational Resources: A Study of Teachers' and Students' Perspectives. The International Review of Research in Open and Distributed Learning, v. 18, n. 4, 2017. https://doi.org/10.19173/irrodl.v18i4.2977. Acesso em 10 de fevereiro de 2018.

LANE, A; McANDREW, P. Are open educational resources systematic or systemic change agents for teaching practice? British Journal of Educational Technology, n. 41. 2010. doi: 10.1111/j.1467--8535.2010.01119.x. Acesso em 28 de março de 2018.

LEFFA, V. Uma outra aprendizagem é possível: colaboração em massa, recursos educacionais abertos e ensino de línguas. Trab. Ling. Aplic., Campinas, v. 55, n. 2, 2016. http://dx.doi.org/10.1590/010318134942176081. Acesso em 11 de julho de 2019.

LEITE, S. Afetividade nas práticas pedagógicas. Temas em Psicologia, v. 20, n. 2, 2012. DOI: 10.9788/TP2012.2-06. Acesso em 20 de dezembro de 2019.

LEMOS, A. Cibercultura como território recombinante. In: TRIVINHO, E., CAZELOTO, E. (orgs). A cibercultura e seu espelho. SP: Abciber/Itaú Cultural, 2009.

LEMOS, A. Cibercultura. Tecnologia e Vida Social na Cultura Contemporânea. Sulina, Porto Alegre., 2002.

LESSIG, L. Cultura Livre: Como a grande mídia usa a tecnologia e a lei para barrar a criação cultural e controlar a criatividade. São Paulo, Trama, 2005. Disponível em: http://www.scribd.com/doc/5266831/Lawrence-Lessig-CulturaLivre. Acesso em 17 de julho de 2017.

LESSIG, L. The Future of Ideas. New York: Random House, 2001.

LEVIN, J.; FOX, J. Estatística para Ciências Humanas. São Paulo: Pearson, 2004

LITTEJOHN, A.; HOOD, N. How educators build knowledge and expand their practice: the case of open education resources. British Journal of Educational Technology, v. 48, n, 2, 2017. Disponível em: https://onlinelibrary.wiley.com/doi/abs/10.1111/bjet.12438

LITTLEJOHN, A. et al. Characterising effective eLearning resources. Computers \& Education, v, 50, n.3, 2008. Disponível em http://www.sciencedirect.com/science/article/pii/S0360131506001254. Acesso em 11 de agosto de 2017.

LUCAS, M.; MOREIRA, A. DigCompEdu: quadro europeu de competência digital para educadores. Aveiro: UA, 2018.

MACHADO, J. Dicionário etimológico da língua portuguesa. $2^{\mathrm{a}}$ ed. Lisboa: Editora Confluência, 1967.

MAIA, J. Investigando o desenvolvimento profissional docente em Mestrados Profissionais em Ensino de Ciências. Tese (Doutorado em Ensino de Ciências) Faculdade de Educação, Instituto de Física, Instituto de Química e Instituto de 
Biociências, Universidade de São Paulo, São Paulo, 2017.

MANOVICH, L. The Language of new media. Cambridge, MA: MIT, 2001.

MANOVICH, L. Remixability and Modularity, 2005 Disponível em: http://manovich.net/content/04-projects/046-remixability-andmodularity/43_article_2005.pdf. Acesso em 17 de outubro de 2017.

MARIANI, M.; ALENCAR, E. Criatividade no trabalho docente segundo professores de história: limites e possibilidades. Rev. Psicologia Escolar e Educacional, v. 9, n. 1, p. 27-35, 2005. Disponível em: http://pepsic.bvsalud.org/scielo.php?script=sci_arttext\&pid=S141385572005000100003. Acesso em 11 de março de 2018.

MARQUES, M. Gestão Curricular Intencional numa Comunidade de Prática Online. Um estudo de caso envolvendo professores de ciências. 2008. 152 f. Dissertação de mestrado, Universidade de Aveiro, Aveiro, 2008

MARTINEZ, G et al., 2016. The Integration of Open Educational Resources to the Mathematics Curriculum: Experiences of Students and Teachers of Secondary Education in Mexico. Pedagogika / Pedagogy Vol. 122, No. 2, pp. 94 109, 2016. http://dx.doi.org/10.15823/p.2016.23. Acesso em 23 de abril de 2019.

MARTINS, B. Autoria em rede - um estudo dos processos autorais interativos de escrita nas redes de comunicação. 2012. 155 f. Universidade de São Paulo, São Paulo, 2012.

MARTINS, R.; FLORES, R. A implantação do Programa Nacional de Tecnologia Educacional (ProInfo): revelações de pesquisas realizadas no Brasil entre 2007 e 2011. Rev. bras. Estudos pedagógicos, Brasília, v. 96, n. 242, p. 112 128, 2015. Disponível em http://dx.doi.org/10.1590/S2176-6681/330812273. Último acesso em 15 de outubro de 2019.

MARTINS, T. Concepção de uma Comunidade de Prática Online: um estudo em torno da integração das TIC na disciplina de EVT. 2009. 263 f. Dissertação de mestrado, Universidade de Aveiro, Aveiro, 2008.

MASON, S.; KIMMONS, R. Effects of Open Textbook Adoption on Teachers' Open Practices. The International Review of Research in Open and Distributed Learning, vol, 19, $\quad n . \quad 3, \quad 2018 . \quad$ Disponível em: https://doi.org/10.19173/irrodl.v19i3.3517. Acesso em 11 de março de 2019.

MAZZARDO, M.; NOBRE, A.; MALLMANN, E. Professores efetivando os 5Rs de aberturas dos recursos educacionais abertos. "REAeduca: revista de educação para o século XXI, n. 2, 2016. Disponível em: https://repositorioaberto.uab.pt/handle/10400.2/5736. Acesso em 11 de março de 2019.

MCLUHAN, M. Os meios de comunicação como extensões do homem. São Paulo: Editora Cultrix, 2007.

MC KERLICH, R.; IVES, C, MC GREAL, R. Measuring Use and Creation of Open Educational Resources in Higher Education. The international Review of research in open and distance learning, v. 14, n 4, 2013. Disponível em: https://doi.org/10.19173/irrodl.v14i4.1573. Acesso em 24 de julho de 2019.

MEDEIROS, Z. Letramento digital em contextos de autoria na internet. Tese (Doutorado em Educação) - Faculdade de Educação, Universidade Federal de 
Minas Gerais, Belo Horizonte, 2011.

MELUCCI, A. Por uma sociologia reflexiva. Pesquisa qualitativa e cultura. Petrópolis: Vozes, 2005.

MERRIAM, J.B. Qualitative research and case study applications in education. San Francisco (CA): Jossey-Bass, cop., 1998.

MICHAELIS. Moderno Dicionário da Língua Portuguesa. Disponível em: $<$ http://michaelis.uol.com.br/moderno/portugues/index.php>. Acesso em: $03 \mathrm{de}$ janeiro de 2020.

MIRALLES-MARTINEZ, P., GÓMEZ-CARRASCO, C., FONTAL-MERILLAS, $O$. Recursos digitales y metodologia didáctica em la formación inicial de docentes de Historia. Revista Científica de Educomunicación, v. 61, n. 4, p. 4556, 2019. Disponível em https://doi.org/10.3916/C61-2019-04. Acesso em 29 de dezembro de 2019.

MISHRA, P.; KOEHLER, M.J. Technological pedagogical contente knowledge: A framework for integrating technology in teacher knowledge. Teachers College Record, v. 108, 2006. Disponível em: http://one2oneheights.pbworks.com/f/MISHRA_PUNYA.pdf. Acesso em $01 \mathrm{de}$ julho de 2019.

MILLS. C. Do artesanato Intelectual. In: Imaginação Sociológica. Zahar Editores: Rio de Janeiro, 1965.

MORAIS, M.; PINHO, M. Concepções de criatividade no contexto educacional: um novo olhar formativo. Rev. Contrapontos, v. 17, n.2, 2017. Disponível em https://siaiap32.univali.br/seer/index.php/rc/article/view/8680/www.univali.br/ppg e. Acesso em 08 de agosto de 2019.

MORIN, E. Ciência com consciência. 8 ed. Rio de Janeiro: Bertrand Brasil, 2005. MONTEIRO, H. Práticas de utilização de computadores portáteis. Um estudo de caso numa Escola Básica dos 2. ${ }^{\circ}$ e 3..$^{\circ}$ Ciclos. 2008. 363 f. Dissertação de mestrado, Universidade de Aveiro, Aveiro, Portugal, 2008.

MOCKLER, N. Beyond 'what works': understanding teacher identity as a practical and political tool. Teachers and Teaching: Theory and Practice, v.17, n.5, p.517-528, oct. 2011. Acesso em 24 de agosto de 2018.

MURPHY, P.; WOLDENFEN, F. Developing a pedagogy of mutuality in a capability approach: Teachers' experiences of using the Open Educational Resources (OER) of the teacher education in sub-Saharan Africa (TESSA) programme. International Journal of Educational Development, v. 33, n. 3, 2013. Disponível em: 10.1016/j.ijedudev.2012.09.010. Acesso em 24 de julho de 2019.

NORNBERG, M; SILVA, G. Processos de escrita e autoria sobre a ação docente enquanto prática formativa. Rev. Educar em Revista: Curitiba, n. 54, p. 185-201, out./dez., 2014.

OLIVEIRA, F. SPSS básico para análise de dados. Rio de Janeiro: Editora Ciência Moderna, 2007.

OLIVEIRA, Z.; ALENCAR, E. Criatividade na pós-graduação stricto sensu: uma presença possível e necessária. Rev. Educação Pública: Cuiabá, v. 23, n.52, p. 53-75, jan./abr., 2014. Acesso em 20 de setembro de 2018. 
OLIVEIRA, Z.; ALENCAR, E. A criatividade faz a diferença na escola: o professor e o ambiente criativos. Rev. Contrapontos: Itajaí, v. 8, n. 2, p. 295 - 306, mai./ago., 2008. Acesso em 20 de setembro de 2018.

OLIVEIRA, A.; LIMA, A. Vygostky e os processos criativos de professores ante a realidade atual. Rev. Educação \& Realidade, Porto Alegre, v. 42, n. 4, p. 1399 1419, out./ dez. 2017. Disponível em: http://dx.doi.org/10.1590/2175-623662025. Acesso em 20 de setembro de 2018.

OSTROWER, F. Criatividade e o processo de criação. $15^{\mathrm{a}}$ ed. Petrópolis: Editora Vozes, 2001.

PALAGI, A. Formação de professores em tecnologias digitais em diálogo com as políticas públicas no estado do Paraná. 2016. $252 \mathrm{f}$. Tese de doutorado. Universidade Vale do Rio dos Sinos, São Leopoldo, 2016.

PARANÁ. TV Pendrive. Portal Dia a Dia. Disponível em: http://www.diaadia.pr.gov.br/tvpendrive/modules/conteudo/conteudo.php?conteud o=4). Acesso em 09 de dez de 2019

PARDAL; LOPES. Métodos e técnicas de investigação social. Porto: Areal, 2011.

PASSOS, C. et al. Desenvolvimento profissional do professor que ensina Matemática: Uma meta-análise de estudos brasileiros. Rev. Quadrante, v. 15, n. 1 e 2, 2006 .

PEREZ-GOMEZ, A. Aprender a educar. Nuevos desafíos para la formación de docentes. Revista Interuniversitaria de Formación del Profesorado. Zaragoza: 2010. Disponível

em: http://www.aufop.com/aufop/uploaded_files/articulos/1279235548.pdf. Acesso em 05 de março de 2019.

PETTERSSON, F. On the issues of digital competence in educational contexts - a review of literature. Education and Information Technologies, v. 23, n. 3, 2018. Disponível em: DOI10.1007/s10639-017-9649-3. Acesso em 20 de maio de 2019.

PIMENTA, S. Professor Reflexivo: construindo uma crítica. In PIMENTA, S e GHEDIN, E. (orgs.) Professores Reflexivos no Brasil gênese e crítica de um conceito. São Paulo: Ed. Cortez, 2006.

PINTO, N. Saberes docentes e processos formativos. Rev. Diálogo Educacional, v. 2, n. 2001. 3, Disponível em https://www.redalyc.org/pdf/1891/189118142004.pdf. Acesso em 25 de agosto de 2019

PISCHETOLA, M. Inclusão digital e educação. A nova cultura da sala de aula. Petrópolis; Vozes; Rio de Janeiro: Editora PUC-Rio, 2016.

PISCHETOLA, M.; HEINSFELD, B. "Eles já nascem sabendo!": desmistificando o conceito de nativos digitais no contexto educacional. Rev. Novas tecnologias e educação, v. 16, n. 1, 2018. Disponível em: https://seer.ufrgs.br/renote/article/view/85929. Acesso em 25 de agosto de 2019

PIRKKALAINEN, H.; JOKINEN, J.; PAWLOWSKI, J. Understanding Social OER Environments - A Quantitative Study on Factors Influencing the Motivation to Share and Collaborate. IEEE - Transactions on learning Technologies, v. 7, n. 4, 2014. Disponível em: 10.1109/TLT.2014.2323970. Acesso em 20 de setembro de 2018. 
PIRKKALAINEN; PAWLOWSKY, PAPPA. Educators' open educational collaboration online: The dilemma of emotional ownership. Computers \& Education, n. 106, 2017. http://dx.doi.org/10.1016/j.compedu.2016.12.005. Acesso em 23 de setembro de 2018.

PRETTO, N. (2012) Professores- autores em rede. In SANTANA, B.; ROSSINI, C.; PRETTO, N. (orgs.) Recursos Educacionais Abertos: práticas colaborativas política pública. Salvador: Edufba; São Paulo: Casa da Cultura Digital.

QUIVY, R., \& CAMPENHOUDT, L. Manual de Investigação em Ciências Sociais. 6 ed. Lisboa: Gradiva, 2013.

RABY, C. Analyse du cheminement qui a mené des enseignants du primaire à développer une utilisation exemplaire des technologies de l'information et de la communication em classe. 2004. 459 f. Doctoral dissertation, Université du Québec à Montréal, Montreal, QC, Canadá, 2004.

RAGNEDDA, M.; MUSCHERT, G. (Eds.). The digital divide: The Internet and social inequality in international perspective. London, UK: Routledge, 2013.

RAMOS, J.; Avaliação e Qualidade de Recursos Educativos Digitais. GEPE/Ministério da Educação, 2012. Disponível em: http://erte.dgidc.minedu.pt/files/@crie/1262962176_CadernosSACAUSEF_V_JLR_pag11a17_PT.pdf Acesso em 02 de agosto de 2017.

REIS, E. Estatística aplicada. Lisboa : Edições Sílabo, 1997

RECKER, M. et al. Teaching, designing, and sharing: a context for learning objects. Interdisciplinary Journal of Knowledge and Learning Objects, v.1, 2005.

ROSSINI, C. Green-Paper: The State and Challenges of OER in Brazil: From Readers to Writers? Berkman Center Research Publication n. 1 2010. Disponível em: https://ssrn.com/abstract=1549922. Acesso em 18 de setembro de 2017.

RYAN, R; DECI, E. Intrinsic and Extrinsic Motivations: Classic Definitions and New Directions. Contemporary Educational Psychology, v 25, 54-67, 2000. Disponível em https://www.sciencedirect.com/journal/contemporary-educationalpsychology/vol/25/issue/1. Acesso em 18 de novembro de 2018

ROSSINI, T. Pesquisa-design formação: uma proposta metodológica para produção de Recursos Educacionais Abertos na cibercultura. Tese (Doutorado) Faculdade de Educação, Universidade do Estado do Rio de Janeiro, 2015.

SACRISTÁN, G. Consciência e acção sobre a prática como libertação profissional dos professores. In Nóvoa, A. Profissão Professor. Porto Editora: Porto, 1995.

SALES, M. A arquitetura do desejo de aprender: autoria docente em debate. Tese (Doutorado em Educação) - Faculdade de Educação, Universidade Federal da Bahia, Salvador, 2009.

SANTANA, B. Materiais didáticos digitais e recursos educacionais abertos. In SANTANA, B.; ROSSINI, C.; PRETTO, N. (orgs.) Recursos Educacionais Abertos: práticas colaborativas política pública. Salvador: Edufba; São Paulo: Casa da Cultura Digital.

SANTOS, A. Educação Aberta: histórico, práticas e o contexto dos recursos educacionais abertos. In SANTANA, B.; ROSSINI, C.; PRETTO, N. (orgs.) 
Recursos Educacionais Abertos: práticas colaborativas política pública. Salvador: Edufba; São Paulo: Casa da Cultura Digital, 2012.

SAPIRE, I; REED, Y. Collaborative design and use of open educational resources: a case study of a mathematics teacher education project in South Africa. Distance Education, 32:2, 2011. DOI: 10.1080/01587919.2011.584847. Acesso em 12 de abril de 2019.

SCHON, D. Educando o Profissional Reflexivo: um novo design para o ensino e aprendizagem. Porto Alegre: Artmed, 2000.

SELWYN, N. Technology and education - why it's crucial to be critical? In Bulfin, S., Johnson, N. \& Bigum, C. (eds.). Critical perspectives on technology and education. New York, Palgrave Macmillan, 2015.

SELWYN, N.; FERREIRA, G. Educação e Tecnologia: questões críticas. In FERREIRA, G.; ROSADO, A.; CARVALHO, J. (Orgs.) Educação e tecnologia: abordagens críticas. Rio de Janeiro: SESES, 2017.

SHIMAZAKI, N. O uso de REA para o ensino de Libras nos cursos de graduação. O Ensino Superior. Tese (Doutorado em EDUCAÇÃO) Departamento de Educação, Pontifícia Universidade Católica do Paraná, Curitiba, 2017.

SILVA. C. Can I Borrow your Proper Name? Remixing Signatures and the Contemporary Author. In Navas, E., Gallagher, O., burrough, x. The Routledge Companion to Remix Studies. New York: Routledge, 2015.

SILVA, E.; LOUREIRO, M. J.; PISCHETOLA, M. Competências digitais de professores do estado do Paraná (Brasil). EDUSER: Revista de Educação, v. 11, 2019. Acesso em 20 de novembro de 2019.

SOARES, C.; SANTOS, E. Artefatos tecnoculturais nos processos pedagógicos: usos e implicações para os currículos. In: ALVES, Nilda. Libâneo, José Carlos. Temas de Pedagogia: diálogos entre didática e currículo. São Paulo: Editora Cortez, 2012.

SOUZA, M. et al. Autoria na web 2.0 no contexto da educação e a ética dos hackers. Rev. ETD - Educação Temática Digital: Campinas, v. 12, n. esp., p. mar, 2011. Disponível em: https://doi.org/10.20396/etd.v12i0.1208. Acesso em 29 de setembro de 2018.

SPANTE, M. Digital competence and digital literacy in higher education research: Systematic review of concept use. Cogent Education, 2018. https://doi.org/10.1080/2331186X.2018.1519143. Acesso em 28 de abril de 2019.

STAKE, R. Investigación com estúdio de casos. Madrid: ediciones Morata, 2005.

STAGG, A. La adopción de los recursos educativos abiertos: un continuo de práctica abierta. Revista del Universidad y Sociedad del Conocimiento, v. 11, n. 3, 2014.2 Disponível em: http://rusc.uoc.edu/rusc/es/index.php/rusc/article/view/v11n3-stagg.html. Acesso em 03 de fevereiro de 2018.

STERNBERG, R.; LUBART, T. Investing in creativity. American Psychologist. Washington, n. 51, 1996. Disponível em https://psycnet.apa.org/record/199604968-001. Acesso em 02 de agosto de 2018. 
TARDIF, M.; LESSARD, C. O trabalho docente. Elementos para uma teoria da docência como profissão de interações humanas. Petrópolis, RJ: Vozes, 2014

TARDIF, M. Saberes profissionais dos professores e conhecimentos universitários. Elementos para uma epistemologia da prática profissional dos professores e suas conseqüências em relação à formação para o magistério. Revista Brasileira de Educação. ANPED, São Paulo, n. 13, p. 5-24, jan./abr. 2000. Disponível

em: http://www.anped.org.br/rbe/rbedigital/RBDE13/RBDE13_05_MAURICE_TAR DIF.pdf >. Acesso em: 15 de novembro de 2019.

TARDIF, M.; LESSARD, C. e LAHAYE, L. Os professores face ao saber: Esboço de uma problemática do saber docente. In: "Dossiê: Interpretando o trabalho docente". Teoria \& Educação n 4, Porto Alegre: Pannônica, 1991, p. 215-233. Disponível em encurtador.com.br/psMQ4. Acesso em 01 de outubro de 2019.

TERUYA, L. Visualização no Ensino de Química: Apontamentos para a pesquisa e desenvolvimento de recursos educacionais. Rev. Química Nova, v. 36, n.4, 2013. Disponível em: http://quimicanova.sbq.org.br/detalhe_artigo.asp?id=2943. Acesso em 16 de março de 2018.

TUCKMAN, B. W. Manual de Investigação em Educação. Como conceber e realizar o processo de investigação em Educação. (2.a ed.). Lisboa: FCG, 2002

UEHARA, F. et al. O uso de objetos de aprendizagem no ensino fundamental: um estudo bibliométrico. Revista Ibero-americana de estudos em educação, v. 12, n. 2, 2017. https://doi.org/10.21723/riaee.v12.n.esp.2.10308. Acesso em 03 de março de 2018.

UGARTE, D. O poder das redes. Porto Alegre: EdiPUCRS, 2008

WELLER, M. Et al. The Impact of OER on Teaching and Learning Practice. Open Praxis, 2015. Disponível em: https://openpraxis.org/index.php/OpenPraxis/article/view/227. Acesso em 19 de agosto de 2018.

UNESCO. Tecnologias para a transformação da educação: experiências de sucesso e expectativas. Organização das Nações Unidas para a Educação, a Ciência e a Cultura (UNESCO), 2014. Disponível em: http://fundacaosantillana.org.br/seminario-tecnologia/pdf/tecnologias-para-atransformacao-da-educacao.pdf. Acesso em 20 de setembro de 2016.

UNESCO. Padrões de Competências em TIC para professores - diretrizes de implementação. Organização das Nações Unidas para a Educação, a Ciência e a Cultura (UNESCO), 2014. Disponível em: http://unesdoc.unesco.org/images/0015/001562/156209por.pdf. Acesso em 20 de setembro de 2016.

VAGULA, E. Recursos Educacionais Abertos: formação de alunos e professores de uma escola pública. Tese (Doutorado) - Departamento de Educação - Pontifícia Universidade Católica do Paraná, Curitiba, 2014.

VAN ACKER, F. Et al. The role of knowledge sharing self-efficacy in sharing Open Educational Resources. Computer in Human Behavior, vol. 39, 2014. https://doi.org/10.1016/j.chb.2014.07.006. Acesso em 15 de outubro de 2019. 
VÁZQUEZ-CANO, E.; MARTÍN-MONJE, E.; LARRETA - AZELAIN, M. Analysis of PLEs' implementation under OER design as a productive teaching-learning strategy in Higher Education. A case study at Universidad Nacional de Educación a Distancia. Digital Educaction Review, n. 29, p. 62-85, 2016. Disponível em: http://revistes.ub.edu/index.php/der/article/view/15443. Acesso em 15 de outubro de 2019.

VEIGA, I. Repensando a Didática. São Paulo: Papirus, 1996. Disponível em http://didaticageraluece.blogspot.com.br/2011/10/texto-06-planejamento-doensino-numa.html. Acesso em 23 de agosto de 2019.

VELOSO, M; BONILLA, M. O professor e a autoria em tempos de cibercultura: a rede da criação dos atos de currículo. Rev. Brasileira de Educação, v. 23, 2018. Doi://dx.doi.org/10.1590/S1413-24782018230026. Acesso em 21 de outubro de 2019

VELOSO, M. O professor e a autoria no contexto da cibercultura: redes da criação no cotidiano da escola. Tese (Doutorado em Educação) - Faculdade de Educação, Universidade Federal da Bahia, 2014.

VERAS, R., FERREIRA, S. A afetividade na relação professor-aluno e suas implicações na aprendizagem em contexto universitário. Educ. rev., 38(1), 2010. Disponíbel em: https://bit.ly/2ut2HDi. Acesso em 20 de dezembro de 2019.

WECHSLER, Solange. Criatividade e Inovação. O impacto de uma educação estimuladora. S/D. Disponível em: http://www.criabrasilis.org.br/arquivos/pdfs/100_criatividade.pdf. Acesso em 22 de outubro de 2019.

WESSELS, B. Autentication, Status, and Power in a Digitally Organized Society. International Journal of Communication 9: 2015.

WILEY, D. The access compromise and the 5R. Iterating toward openness, 2014. Acessado de http://opencontent.org/blog/archives/3221. Acesso em $12 \mathrm{de}$ outubro de 2018.

WOODMANSEE, M. The Genius and the Copyright: Economic and Legal Conditions of the Emergence of the 'Author'. Eighteenth-Century Studies, vol. 17, no. 4, 1984, pp. 425-448. JSTOR, JSTOR. Disponível em: https://www.jstor.org/stable/2738129?seq=1\#page_scan_tab_contents. Acesso em 15 de outubro de 2018.

YIN, R. Estudo de Caso: planejamento e métodos. Porto Alegre: Bookman, 2001. 


\section{APÊNDICES}

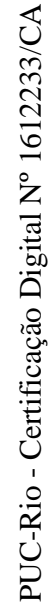




\title{
Apêndice I - Termo de Consentimento Livre e Esclarecido
}

\author{
Pontifícia Universidade Católica $_{\text {a }}$ \\ DO RIO DE JANEIRO
}

TERMO DE CONSENTIMENTO LIVRE E ESCLARECIDO

Convido você a participar voluntariamente da pesquisa para o doutorado que realizo na Pontifícia Universidade Católica do Rio de Janeiro, PUC-Rio. A pesquisa intitula-se, provisoriamente:

"RECURSOS EDUCACIONAIS: usos e autoria na dinâmica da Rede"

O objetivo é descrever e compreender os usos que os professores fazem dos recursos educacionais digitais em suas práticas pedagógicas e os diferentes graus de autoria associados a esses usos, considerando a experiência em rede e os contextos sociais.

Estamos utilizando o questionário on-line para coletar os dados. Agradeço a você antecipadamente pela colaboração na pesquisa.

Abaixo seguem meus dados, caso você deseje falar comigo.

Pesquisadora Responsável:

Doutoranda em Educação: Eunice de Castro e Silva | nicepeda@gmail.com | Tel. (21) 991992667.

Orientadora da Pesquisa:

Profa. Dra. Magda Pischetola | magda@puc-rio.br.

Possíveis riscos:

A participação nesta pesquisa não traz complicações legais. Contudo, existe a possibilidade do participante se sentir desconfortável ou constrangido devido a alguma pergunta. Em caso como esses fica assegurado ao participante o direito de não responder. Nenhum dos procedimentos usados oferece riscos à sua dignidade. Ao participar desta pesquisa você não terá nenhum benefício direto. 
Entretanto, esperamos que este estudo contribua com informações importantes sobre as práticas docentes com os usos de recursos educacionais digitais. Se necessário, o participante pode clicar em "Sair", no botão que se encontra no canto superior direito do formulário a qualquer momento.

Para participar da pesquisa, marque o aceite de participação e indique o seu email, que será mantido em sigilo.

1. De maneira voluntária, livre e esclarecida, concordo em participar da pesquisa acima identificada. Estou ciente dos objetivos do estudo, dos procedimentos metodológicos, das garantias de confidencialidade e da possibilidade de esclarecimentos permanentes sobre os mesmos. Está claro que minha participação é isenta de despesas e que meu e-mail não será publicado sem minha prévia autorização por escrito. Estou ciente de que, em qualquer fase da pesquisa, tenho a liberdade de recusar a minha participação ou retirar meu consentimento.

( ) Aceito

( ) Não aceito 


\section{Apêndice II - QUESTIONÁRIO - RECURSOS EDUCACIONAIS: usos e autoria na dinâmica da rede}

\section{Bloco 1: Perfil dos Respondentes}

3) Sexo

4) Nível socio-econômico (Salários Mínimos)

a) até $2 \mathrm{SM}$; b) de 2 a $3 \mathrm{SM}$; c)de 3 a $5 \mathrm{SM}$ d) de 5 a $10 \mathrm{SM}$ e) mais de $10 \mathrm{SM}$

5) Idade

a) Até 30 anos; b) Mais de 30 e até 45 anos; c) Mais de 45 anos

6) Estado

(Opções com os estados brasileiros)

7) Tempo de Docência

a) Ate 3 anos b) De 3 a 10 anos c) Mais de 10 anos

8) Selecione a(s) dependências administrativas em que atua.

a) Particular; b) pública federal; c) pública estadual; d) pública municipal e) outro

9) Selecione o(s) segmento(s) de atuação em que trabalha

a) Educação infantil; b) $1^{\circ}$ Segmento do Fundamental; c) $2^{\circ}$ Segmento do Fundamental; d) Ensino Médio e) Ensino Superior 
10) Área(s) do conhecimento em que sou docente

a) Linguagens b) Ciências da Natureza c) Matemática d)Ciências Humanas e) Áreas Integradas.

11) Maior titulação de formação

a) Ensino Médio (Formação de Professores); b) Licenciatura; c) Especialização; d) Mestrado e) Doutorado

12) Participou de formação continuada sobre educação e tecnologia nos últimos dois anos?

a) Sim - presencial; b) Sim - a distância c) Sim - presencial e a distância d)Não

13) Caso tenha participado da formação continuada, indique sua forma de acesso.

a) Pago pelo professor b) Oferecido pela escola c) Oferecido pelo governo d)Oferecido por uma empresa, ONG, associação ou outra entidade e) Oferecido por uma Universidade f) Outros.

\section{Bloco 2 - Contexto Profissional e Tecnológico}

14) Selecione as tecnologias que são acessíveis para os professores e estão funcionando na(s) instituição(ções) em que você atua: ( ) Laboratório de informática.

( ) Computador fixo em sala de aula.

( ) Laptop

( ) Projetor fixo em sala de aula.

( ) Projetor portátil.

( ) Tablets.

( ) Internet banda larga. 
( ) Lousa interativa.

( ) Televisão e Vídeo.

( ) Outros, quais?

15) Selecione a frequência aproximada em que você utiliza cada tecnologia em seu cotidiano

\begin{tabular}{|c|c|c|c|c|c|}
\hline & Não uso & $\begin{array}{l}\text { Uma vez por } \\
\text { semana }\end{array}$ & $\begin{array}{c}\text { Duas a três vezes } \\
\text { por semana }\end{array}$ & $\begin{array}{c}\text { Quatro a cinco vezes } \\
\text { na semana }\end{array}$ & Todos os dias \\
\hline \multicolumn{6}{|l|}{ Celular } \\
\hline \multicolumn{6}{|l|}{ Tablets } \\
\hline \multicolumn{6}{|c|}{$\begin{array}{l}\text { Computador para fins } \\
\text { pessoais. }\end{array}$} \\
\hline \multicolumn{6}{|c|}{$\begin{array}{l}\text { Computador para fins } \\
\text { pedagógicos }\end{array}$} \\
\hline \multicolumn{6}{|c|}{ Console de Gamers } \\
\hline \multicolumn{6}{|l|}{ Lousa interativa } \\
\hline \multicolumn{6}{|l|}{ Projetor } \\
\hline Televisão e vídeo & & & & & \\
\hline
\end{tabular}


16) Considerando suas habilidades tecnológicas, julgue as práticas a seguir.

\begin{tabular}{|l|l|l|l|}
\hline & Pouco & Às vezes & Muito \\
\hline $\begin{array}{l}\text { Desenvolvo atividades no computador que requerem noções de } \\
\text { programação . }\end{array}$ & & & \\
\hline $\begin{array}{l}\text { Utilizo o ambiente virtual de aprendizagem (Moodle, Google } \\
\text { Classroom) para criar atividades com os alunos }\end{array}$ & & & \\
\hline Modifico conteúdos disponibilizados na internet. & & & \\
\hline Realizo downloads e instalo programas ou aplicativos. & & & \\
\hline $\begin{array}{l}\text { Compartilho na internet conteúdos (imagens, vídeos, textos) de } \\
\text { autoria própria. }\end{array}$ & & & \\
\hline Realizo edição de imagem. & & & \\
\hline Realizo edição de vídeo. & & & \\
\hline Desenvolvo trabalhos de produções midiáticas com os alunos. & & & \\
\hline Planejo atividades em que preciso utilizar o computador. & & & \\
\hline Realizo atividades de criação/ edição de vídeo com os alunos. & & & \\
\hline Utilizo a internet para aprender novas metodologias de ensino. & & & \\
\hline Supervisiono as pesquisas que os alunos fazem na internet. & & & \\
\hline Planejo atividades que permitem aos alunos trabalharem & & & \\
\hline
\end{tabular}




\begin{tabular}{|l|l|l|l|}
\hline colaborativamente com o uso de tecnologias. & & & \\
\hline $\begin{array}{l}\text { Adoto formas de avaliação em que o aluno possa apresentar } \\
\text { uma produção por meio de tecnologias }\end{array}$ & & & \\
\hline
\end{tabular}

17) Considerando a relação entre seu contexto de trabalho e as tecnologias, avalie

\begin{tabular}{|l|l|l|l|}
\hline & Pouco & Às vezes & Muito \\
\hline $\begin{array}{l}\text { As tecnologias estão presentes no Projeto Político } \\
\text { Pedagógico da instituição em que atuo. }\end{array}$ & & & \\
\hline Surgem como temática nas reuniões de professores. & & & \\
\hline $\begin{array}{l}\text { São incentivadas no planejamento pela gestão } \\
\text { pedagógica. }\end{array}$ & & & \\
\hline Estão integradas no currículo da instituição. & & & \\
\hline $\begin{array}{l}\text { São compartilhadas e o uso pedagógico é incentivado } \\
\text { pelos professores. }\end{array}$ & & & \\
\hline
\end{tabular}

\section{Bloco 3 - Recursos Educacionais Digitais}

18) Classifique em ordem de importância os Recursos Educacionais Digitais (RED) que você mais utiliza. Enumere as caixas de seleção na primeira coluna, considerando 1 como o que você mais utiliza e 10 como o que você menos utiliza 
Vídeos

Textos

Jogos

Apresentações

Simulações

Podcast

Imagens/ llustrações

Objetos multimídia

Planos de Aula

Conteúdo para avaliação de alunos

19) Indique o seu grau de concordância sobre práticas de utilização de RED a partir dos itens a seguir.

\begin{tabular}{|l|l|l|l|}
\hline & Discordo & $\begin{array}{c}\text { Não concordo/ } \\
\text { Nem discordo }\end{array}$ & Concordo \\
\hline $\begin{array}{l}\text { As atividades pedagógicas com os recursos } \\
\text { influenciam o professor a adotar novos métodos } \\
\text { pedagógicos. }\end{array}$ & & & \\
\hline $\begin{array}{l}\text { Consigo inserir os RED no meu planejamento de } \\
\text { ensino. }\end{array}$ & & & \\
\hline $\begin{array}{l}\text { As práticas com RED dependem da experiência } \\
\text { prévia com o uso das tecnologias. }\end{array}$ & & & \\
\hline
\end{tabular}




\begin{tabular}{|l|l|l|l|}
\hline Aumentam a motivação dos alunos para aprender & & & \\
\hline $\begin{array}{l}\text { Promovem novas oportunidades para os alunos } \\
\text { que não aprendem com métodos tradicionais. }\end{array}$ & & & \\
\hline $\begin{array}{l}\text { Os alunos ficam mais interessados nas aulas em } \\
\text { que há atividades com RED. }\end{array}$ & & & \\
\hline $\begin{array}{l}\text { As práticas com RED dependem da formação do } \\
\text { professor. }\end{array}$ & & & \\
\hline $\begin{array}{l}\text { O uso dos RED motiva os professores a } \\
\text { repensarem as suas práticas pedagógicas. }\end{array}$ & & & \\
\hline Utilizo RED porque os alunos solicitam & & & \\
\hline $\begin{array}{l}\text { Minhas aulas ficaram mais interessantes quando } \\
\text { passei a utilizar os RED. }\end{array}$ & & & \\
\hline $\begin{array}{l}\text { As práticas com os RED dependem do tempo de } \\
\text { experiência do professor. }\end{array}$ & & & \\
\hline
\end{tabular}

20) Aponte sua relação com os Recursos Educacionais Digitais (RED):

\begin{tabular}{|l|l|l|l|}
\hline & Pouco & Às vezes & Muito \\
\hline $\begin{array}{l}\text { Recomendo recursos educacionais para outros } \\
\text { professores na minha instituição. }\end{array}$ & & & \\
\hline
\end{tabular}




\begin{tabular}{|l|l|l|l|}
\hline $\begin{array}{l}\text { Participo de fórum de discussão ou de redes } \\
\text { sociais sobre práticas pedagógicas com RED. }\end{array}$ & & & \\
\hline $\begin{array}{l}\text { Utilizo RED recomendados por outros professores } \\
\text { ou pela coordenação pedagógica. }\end{array}$ & & & \\
\hline $\begin{array}{l}\text { Já participei de alguma formação que tenha } \\
\text { abordado o tema dos recursos educacionais }\end{array}$ & & & \\
\hline $\begin{array}{l}\text { Mantenho um blog/canal ou página em que divulgo } \\
\text { minhas práticas com os RED. }\end{array}$ & & & \\
\hline $\begin{array}{l}\text { Costumo acessar aos RED por meio de } \\
\text { repositórios. (Portal do professor; Educopédia, } \\
\text { Edumatec). }\end{array}$ & & & \\
\hline $\begin{array}{l}\text { Costumo acessar RED por meio motores de } \\
\text { busca como o Google. }\end{array}$ & & & \\
\hline
\end{tabular}

21) Analise as práticas com os recursos educacionais digitais (RED), tendo como base aquilo que você costuma realizar.

\begin{tabular}{|l|l|l|l|l|l|}
\hline & Nunca & Raramente & Às vezes & $\begin{array}{c}\text { Quase } \\
\text { sempre }\end{array}$ & Sempre \\
\hline Produzo RED para serem usados em sala de aula & & & & & \\
\hline $\begin{array}{l}\text { Realizo adaptações de RED encontrados em } \\
\text { repositórios }\end{array}$ & & & & & \\
\hline
\end{tabular}




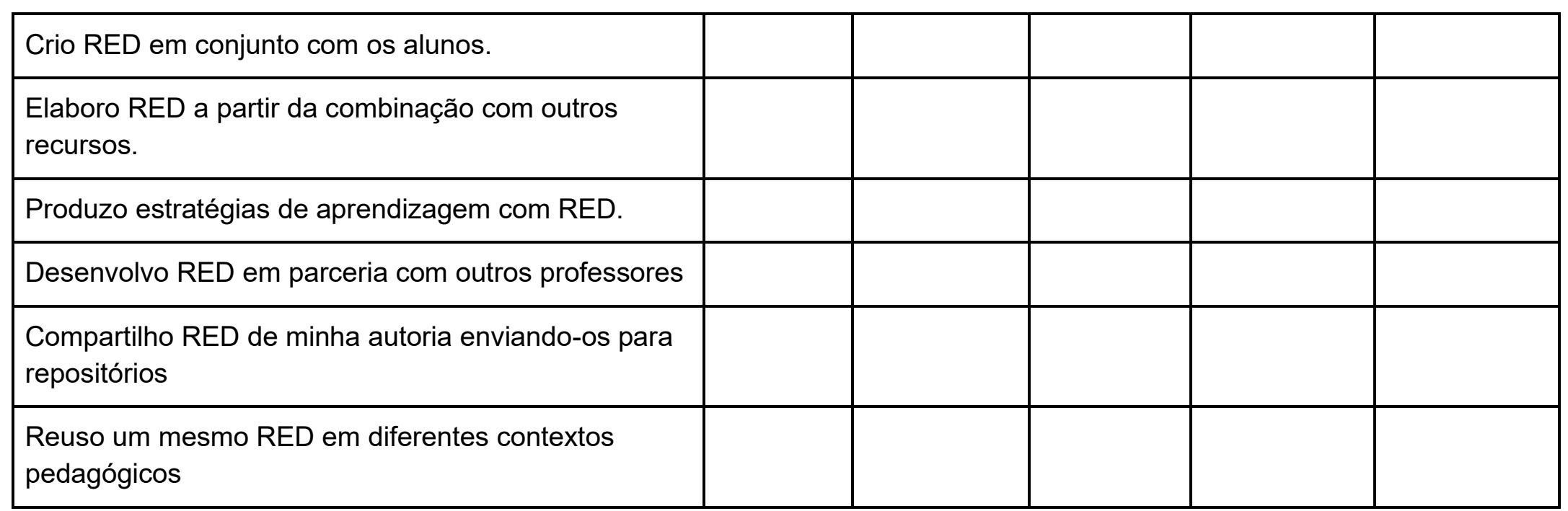

21) Questão aberta: Por que você utiliza os recursos educacionais digitais?

22) Teria disponibilidade em participar de uma entrevista ou grupo focal on-line sobre o tema abordado neste questionário? a) Sim, b) Não. 


\section{Apêndice III - Estatística descritiva}

Questão 03: Sexo

\begin{tabular}{l|c|c}
\multicolumn{1}{c|}{ Sexo } & N & $\%$ \\
\hline Feminino & 484 & 74,0 \\
\hline Masculino & 170 & 26,0 \\
\hline Total & 654 & 100,0 \\
\hline
\end{tabular}

Casos válidos: 654 (91,9\%). Missing: 58 (8,1\%)

Questão 04: Faixa salarial

\begin{tabular}{l|c|c}
\multicolumn{1}{c|}{ Faixa salarial } & $\mathbf{N}$ & \% \\
\hline Até 2 salários mínimos & 49 & 7,4 \\
\hline De 2 a 3 salários mínimos & 111 & 16,9 \\
\hline De 3 a 5 salários mínimos & 252 & 38,3 \\
\hline De 5 a 10 salários mínimos & 208 & 31,6 \\
\hline Mais de 10 salários mínimos & 38 & 5,8 \\
\hline Total & 658 & 100,0
\end{tabular}

Casos válidos: 658 (92,4\%). Missing: 54 (7,6\%)

Questão 05: Faixa Etária

\begin{tabular}{l|c|c}
\hline \multicolumn{1}{c|}{ Faixa etária } & N & $\%$ \\
\hline Até 30 anos. & 42 & 6,4 \\
\hline Mais de 30 até 45 anos. & 280 & 42,9 \\
\hline Mais de 45 anos. & 330 & 50,6 \\
\hline Total & 652 & 100,0 \\
\hline
\end{tabular}

Casos válidos: 652 (91,6\%). Missing: 60 (8,4\%)

Questão 06: Estado em que reside

\begin{tabular}{l|c|c}
\hline \multicolumn{1}{c|}{ Estado em que reside } & $\mathbf{N}$ & \% \\
\hline Espirito Santo & 2 & 0,3 \\
\hline Paraná & 643 & 97,9 \\
\hline Pernambuco & 1 & 0,2 \\
\hline
\end{tabular}




\begin{tabular}{l|c|c}
\hline Santa Catarina & 4 & 0,6 \\
\hline São Paulo & 6 & 0,9 \\
\hline Tocantins & 1 & 0,2 \\
\hline Total & 657 & 100,0 \\
\hline
\end{tabular}

Casos válidos: 657 (92,3\%). Missing: 55 (7,7\%)

Questão 07: Tempo de docência

\begin{tabular}{l|c|c}
\hline \multicolumn{1}{c|}{ Tempo de docência } & $\mathbf{N}$ & $\%$ \\
\hline Até três anos & 43 & 6,6 \\
\hline De três a dez anos & 134 & 20,6 \\
\hline Mais de dez anos & 474 & 72,8 \\
\hline Total & 651 & 100,0 \\
\hline
\end{tabular}

Casos válidos: 651 (91,4\%). Missing: 61 (8,6\%)

Questão 08: Dependências administrativas em que atua

\begin{tabular}{|c|c|c|c|}
\hline \multirow{2}{*}{ Dependências administrativas em que atua } & \multicolumn{2}{|c|}{ Respostas } & \multirow{2}{*}{$\%$ de casos } \\
\hline & $\mathbf{N}$ & $\%$ & \\
\hline Particular & 56 & $7,4 \%$ & $8,6 \%$ \\
\hline Pública Federal & 3 & $0,4 \%$ & $0,5 \%$ \\
\hline Pública Estadual & 632 & $83,7 \%$ & $96,8 \%$ \\
\hline Pública Municipal & 53 & $7,0 \%$ & $8,1 \%$ \\
\hline Outro & 11 & $1,5 \%$ & $1,7 \%$ \\
\hline Total & 755 & $100,0 \%$ & $115,6 \%$ \\
\hline
\end{tabular}

Questão 09: Segmento(s) de atuação em que trabalha

\begin{tabular}{l|c|c|c}
\hline \multirow{2}{*}{ Segmento(s) de atuação em que trabalha } & \multicolumn{2}{|c|}{ Respostas } & \multirow{2}{*}{$\%$ de casos } \\
\cline { 2 - 4 } & $\mathbf{N}$ & $\%$ & \\
\hline Educação Infantil & 36 & $3,2 \%$ & $5,5 \%$ \\
\hline $1^{\circ}$ Segmento do Ensino Fundamental & 95 & $8,5 \%$ & $14,6 \%$ \\
\hline $2^{\circ}$ Segmento do Ensino Fundamental & 434 & $39,0 \%$ & $66,6 \%$ \\
\hline Ensino Médio & 507 & $45,5 \%$ & $77,8 \%$ \\
\hline Ensino Superior & 42 & $3,8 \%$ & $6,4 \%$ \\
\hline Total & 1114 & $100,0 \%$ & $170,9 \%$ \\
\hline
\end{tabular}


Questão 10: Área(s) do conhecimento em que é docente

\begin{tabular}{l|c|c|c}
\hline \multirow{2}{*}{ Área(s) do conhecimento em que é docente } & \multicolumn{2}{|c|}{ Respostas } & \multirow{2}{*}{$\%$ de casos } \\
\cline { 2 - 3 } & $\mathbf{N}$ & $\%$ & \\
\hline Linguagens & 171 & $23,0 \%$ & $27,2 \%$ \\
\hline Ciências da Natureza & 101 & $13,6 \%$ & $16,1 \%$ \\
\hline Matemática & 82 & $11,1 \%$ & $13,0 \%$ \\
\hline Ciências Humanas & 233 & $31,4 \%$ & $37,0 \%$ \\
\hline Áreas integradas & 155 & $20,9 \%$ & $24,6 \%$ \\
\hline Total & 742 & $100,0 \%$ & $118,0 \%$ \\
\hline
\end{tabular}

Questão 11: Maior titulação de formação

\begin{tabular}{l|c|c|c}
\hline \multirow{2}{*}{\multicolumn{1}{c|}{ Maior titulação de formação }} & \multicolumn{2}{c|}{ Respostas } & \multirow{2}{*}{$\%$ de casos } \\
\cline { 2 - 3 } & $\mathbf{N}$ & $\%$ & \\
\hline Ensino Médio & 9 & $1,3 \%$ & $1,4 \%$ \\
\hline Licenciatura/ Bacharelado & 52 & $7,5 \%$ & $8,0 \%$ \\
\hline Especialização & 496 & $71,9 \%$ & $76,0 \%$ \\
\hline Mestrado & 121 & $17,5 \%$ & $18,5 \%$ \\
\hline Doutorado & 12 & $1,7 \%$ & $1,8 \%$ \\
\hline Total & 690 & $100,0 \%$ & $105,7 \%$ \\
\hline
\end{tabular}

Questão 12: Participou de formação continuada sobre educação e tecnologia nos últimos dois anos?

\begin{tabular}{l|c|c}
\hline $\begin{array}{c}\text { Formação continuada sobre } \\
\text { educação e tecnologia nos } \\
\text { últimos dois anos }\end{array}$ & $\mathbf{N}$ & $\%$ \\
\hline Sim & 499 & 77,5 \\
\hline Não & 145 & 22,5 \\
\hline Total & 651 & 100,0 \\
\hline
\end{tabular}

Casos válidos: 644 (90,4\%). Missing: 68 (9,6\%) 
Questão 13: Caso tenha participado da formação continuada, indique sua forma de acesso

\begin{tabular}{l|c|c}
\hline Acesso à formação continuada & $\mathbf{N}$ & $\%$ \\
\hline Pago pelo professor. & 25 & 4,9 \\
\hline Oferecido pela Escola. & 35 & 6,8 \\
\hline Oferecido pelo Governo. & 389 & 75,5 \\
\hline $\begin{array}{l}\text { Oferecido por uma empresa, } \\
\text { ONG, associação ou outra } \\
\text { entidade. }\end{array}$ & 9 & 1,7 \\
\hline Oferecido por uma Universidade. & 36 & 7,0 \\
\hline Outro. & 21 & 4,1 \\
\hline Total & 515 & 100,0 \\
\hline
\end{tabular}

Casos válidos: 515 (72,3\%). Missing: 197 (27,7\%)

Questão 14: Selecione as tecnologias que são acessíveis para os professores e estão funcionando na(s) instituição(ções) em que você atua:

\begin{tabular}{l|c|c|c}
\hline \multirow{2}{*}{$\begin{array}{c}\text { Tecnologias acessíveis para os } \\
\text { professores e estão funcionando na(s) } \\
\text { instituição(ções) em que atua }\end{array}$} & $\mathbf{2}$ & $\%$ & \multirow{2}{*}{ Respostas de casos } \\
\cline { 2 - 3 } & 451 & $20,6 \%$ & $75,5 \%$ \\
\hline Laboratório de Informática & 69 & $3,2 \%$ & $11,6 \%$ \\
\hline Computador fixo em sala de aula & 136 & $6,2 \%$ & $22,8 \%$ \\
\hline Laptop & 132 & $6,0 \%$ & $22,1 \%$ \\
\hline Projetor fixo em sala de aula & 376 & $17,2 \%$ & $63,0 \%$ \\
\hline Projetor portátil & 123 & $5,6 \%$ & $20,6 \%$ \\
\hline Tablets & 323 & $14,7 \%$ & $54,1 \%$ \\
\hline Internet Banda Larga & 91 & $4,2 \%$ & $15,2 \%$ \\
\hline Lousa Interativa & 489 & $22,3 \%$ & $81,9 \%$ \\
\hline Televisão e vídeo & 2190 & $100,0 \%$ & $366,8 \%$ \\
\hline Total & & & \\
\hline
\end{tabular}


Questão 15: Selecione a frequência aproximada em que você utiliza cada tecnologia em seu cotidiano

\begin{tabular}{l|c|c|c|c|c|c}
\hline $\begin{array}{c}\text { Frequência de } \\
\text { utilização das } \\
\text { tecnologias no } \\
\text { cotidiano }\end{array}$ & Não uso & $\begin{array}{c}\text { Uma vez } \\
\text { por } \\
\text { semana }\end{array}$ & $\begin{array}{c}\text { Duas a } \\
\text { três } \\
\text { vezes por } \\
\text { semana }\end{array}$ & $\begin{array}{c}\text { Quatro a } \\
\text { cinco } \\
\text { vezes por } \\
\text { semana }\end{array}$ & $\begin{array}{c}\text { Todos os } \\
\text { dias }\end{array}$ & Total \\
\hline Celular & $23(3,9 \%)$ & $37(6,3 \%)$ & $21(3,6 \%)$ & $12(2,1 \%)$ & $492(84,1 \%)$ & $585(100 \%)$ \\
\hline Tablets & $359(74,5 \%)$ & $41(8,5 \%)$ & $19(3,9 \%)$ & $21(4,4 \%)$ & $42(8,7 \%)$ & $482(100 \%)$ \\
\hline $\begin{array}{l}\text { Computador para } \\
\text { fins pessoais }\end{array}$ & $25(4,4 \%)$ & $39(6,8 \%)$ & $59(10,3 \%)$ & $76(13,3 \%)$ & $374(65,3 \%)$ & $573(100 \%)$ \\
\hline $\begin{array}{l}\text { Computador para } \\
\text { fins pedagógicos }\end{array}$ & $10(1,7 \%)$ & $34(5,8 \%)$ & $70(12 \%)$ & $109(18,7 \%)$ & $361(61,8 \%)$ & $584(100 \%)$ \\
\hline Lousa Interativa & $419(90,3 \%)$ & $27(5,8 \%)$ & $11(2,4 \%)$ & $2(0,4 \%)$ & $5(1,1 \%)$ & $464(100 \%)$ \\
\hline Projetor & $171(32,1 \%)$ & $187(35,2 \%)$ & $113(21,2 \%)$ & $34(6,4 \%)$ & $27(5,1 \%)$ & $532(100 \%)$ \\
\hline Televisão e vídeo & $141(25,9 \%)$ & $202(37,1 \%)$ & $99(18,2 \%)$ & $36(6,6 \%)$ & $66(12,1 \%)$ & $544(100 \%)$ \\
\hline
\end{tabular}

\begin{tabular}{l|c|c|c|c|c|c}
\hline \multirow{2}{*}{$\begin{array}{l}\text { Frequência de utilização das } \\
\text { tecnologias no cotidiano }\end{array}$} & \multicolumn{2}{|c|}{ Missing } & Casos válidos & \multicolumn{2}{c}{ Total } \\
\cline { 2 - 7 } & $\mathbf{N}$ & $\%$ & $\mathbf{N}$ & $\%$ & $\mathbf{N}$ & $\%$ \\
\hline Celular & 127 & $17,8 \%$ & 585 & $82,2 \%$ & 712 & $100,0 \%$ \\
\hline Tablets & 230 & $32,3 \%$ & 482 & $67,7 \%$ & 712 & $100,0 \%$ \\
\hline $\begin{array}{l}\text { Computador para fins } \\
\text { pessoais }\end{array}$ & 139 & $19,5 \%$ & 573 & $80,5 \%$ & 712 & $100,0 \%$ \\
\hline $\begin{array}{l}\text { Computador para fins } \\
\text { pedagógicos }\end{array}$ & 128 & $18,0 \%$ & 584 & $82,0 \%$ & 712 & $100,0 \%$ \\
\hline Lousa Interativa & 248 & $34,8 \%$ & 464 & $65,2 \%$ & 712 & $100,0 \%$ \\
\hline Projetor & 180 & $25,3 \%$ & 532 & $74,7 \%$ & 712 & $100,0 \%$ \\
\hline Televisão e vídeo & 168 & $23,6 \%$ & 544 & $76,4 \%$ & 712 & $100,0 \%$ \\
\hline
\end{tabular}

Questão 16: Considerando suas habilidades tecnológicas, julgue as práticas a seguir.

\begin{tabular}{c|c|c|c|c}
\hline Práticas e habilidades tecnológicas & Pouco & Às vezes & Muito & Total \\
\hline $\begin{array}{l}\text { Desenvolvo atividades no computador } \\
\text { que requerem noções de programação. }\end{array}$ & $331(58 \%)$ & $177(31 \%)$ & $63(11 \%)$ & $571(100 \%)$ \\
\hline
\end{tabular}




\begin{tabular}{|c|c|c|c|c|}
\hline $\begin{array}{l}\text { Utilizo o ambiente virtual de } \\
\text { aprendizagem (Moodle, Google } \\
\text { Classroom) para criar atividades com os } \\
\text { alunos (wikis, fóruns, tarefas). }\end{array}$ & $281(49,3 \%)$ & $167(29,3 \%)$ & $122(21,4 \%)$ & $570(100 \%)$ \\
\hline $\begin{array}{l}\text { Modifico conteúdos disponibilizados na } \\
\text { internet. }\end{array}$ & $141(24,8 \%)$ & $230(40,4 \%)$ & $198(34,8 \%)$ & $569(100 \%)$ \\
\hline $\begin{array}{l}\text { Realizo downloads e instalo programas } \\
\text { ou aplicativos. }\end{array}$ & $114(20 \%)$ & $224(39,4 \%)$ & $231(40,6 \%)$ & $569(100 \%)$ \\
\hline $\begin{array}{l}\text { Compartilho na internet conteúdos } \\
\text { (imagens, vídeos, textos) de autoria } \\
\text { própria. }\end{array}$ & $268(48 \%)$ & $167(29,9 \%)$ & $123(22 \%)$ & $558(100 \%)$ \\
\hline Realizo edição de imagem. & $221(39,8 \%)$ & $210(37,8 \%)$ & $124(22,3 \%)$ & $555(100 \%)$ \\
\hline Realizo edição de vídeo. & $291(54,1 \%)$ & $178(33,1 \%)$ & $69(12,8 \%)$ & $538(100 \%)$ \\
\hline $\begin{array}{l}\text { Desenvolvo trabalhos de produção } \\
\text { midiática com os alunos. }\end{array}$ & $296(53,8 \%)$ & $203(36,9 \%)$ & $51(9,3 \%)$ & $550(100 \%)$ \\
\hline $\begin{array}{l}\text { Planejo atividades em que preciso utilizar } \\
\text { o computador. }\end{array}$ & $84(14,7 \%)$ & $184(32,1 \%)$ & $305(53,2 \%)$ & $573(100 \%)$ \\
\hline $\begin{array}{l}\text { Realizo atividades de criação/edição de } \\
\text { vídeo com os alunos. }\end{array}$ & $344(62,9 \%)$ & $161(29,4 \%)$ & $42(7,7 \%)$ & $547(100 \%)$ \\
\hline $\begin{array}{l}\text { Utilizo a internet para aprender novas } \\
\text { metodologias de ensino. }\end{array}$ & $36(6,3 \%)$ & $178(31 \%)$ & $361(62,8 \%)$ & $575(100 \%)$ \\
\hline $\begin{array}{l}\text { Supervisiono as pesquisas que os alunos } \\
\text { fazem na internet. }\end{array}$ & $189(34,1 \%)$ & $149(26,8 \%)$ & $217(39,1 \%)$ & $555(100 \%)$ \\
\hline $\begin{array}{l}\text { Planejo atividades que permitem aos } \\
\text { alunos trabalharem colaborativamente } \\
\text { com o uso de tecnologias. }\end{array}$ & $170(30,4 \%)$ & $229(41 \%)$ & $160(28,6 \%)$ & $559(100 \%)$ \\
\hline $\begin{array}{l}\text { Adoto formas de avaliação em que o } \\
\text { aluno possa apresentar uma produção } \\
\text { por meio de tecnologias. }\end{array}$ & $197(35,6 \%)$ & $229(41,3 \%)$ & $128(23,1 \%)$ & $554(100 \%)$ \\
\hline
\end{tabular}

\begin{tabular}{l|c|c|c|c|c|c}
\hline \multirow{2}{*}{ Práticas e habilidades tecnológicas } & \multicolumn{2}{|c|}{ Missing } & \multicolumn{2}{c|}{$\begin{array}{c}\text { Casos } \\
\text { válidos }\end{array}$} & \multicolumn{2}{c}{ Total } \\
\cline { 2 - 7 } & $\mathbf{N}$ & $\%$ & $\mathbf{N}$ & $\%$ & $\mathbf{N}$ & $\%$ \\
\hline $\begin{array}{l}\text { Desenvolvo atividades no computador que } \\
\text { requerem noções de programação. }\end{array}$ & 141 & $\begin{array}{c}19,8 \\
\%\end{array}$ & 571 & $\begin{array}{c}80,2 \\
\%\end{array}$ & 712 & $100,0 \%$ \\
\hline $\begin{array}{l}\text { Utilizo o ambiente virtual de aprendizagem } \\
\text { (Moodle, Google Classroom) para criar } \\
\text { atividades com os alunos (wikis, fóruns, tarefas). }\end{array}$ & 142 & $\begin{array}{c}19,9 \\
\%\end{array}$ & 570 & $\begin{array}{c}80,1 \\
\%\end{array}$ & 712 & $100,0 \%$ \\
\hline
\end{tabular}




\begin{tabular}{|c|c|c|c|c|c|c|}
\hline Modifico conteúdos disponibilizados na internet. & 143 & $\begin{array}{c}20,1 \\
\%\end{array}$ & 569 & $\begin{array}{c}79,9 \\
\%\end{array}$ & 712 & $100,0 \%$ \\
\hline $\begin{array}{l}\text { Realizo downloads e instalo programas ou } \\
\text { aplicativos. }\end{array}$ & 143 & $\begin{array}{c}20,1 \\
\%\end{array}$ & 569 & $\begin{array}{c}79,9 \\
\%\end{array}$ & 712 & $100,0 \%$ \\
\hline $\begin{array}{l}\text { Compartilho na internet conteúdos (imagens, } \\
\text { vídeos, textos) de autoria própria. }\end{array}$ & 154 & $\begin{array}{c}21,6 \\
\%\end{array}$ & 558 & $\begin{array}{c}78,4 \\
\%\end{array}$ & 712 & $100,0 \%$ \\
\hline Realizo edição de imagem. & 157 & $\begin{array}{c}22,1 \\
\%\end{array}$ & 555 & $\begin{array}{c}77,9 \\
\%\end{array}$ & 712 & $100,0 \%$ \\
\hline Realizo edição de vídeo. & 174 & $\begin{array}{c}24,4 \\
\%\end{array}$ & 538 & $\begin{array}{c}75,6 \\
\%\end{array}$ & 712 & $100,0 \%$ \\
\hline $\begin{array}{l}\text { Desenvolvo trabalhos de produção midiática } \\
\text { com os alunos. }\end{array}$ & 162 & $\begin{array}{c}22,8 \\
\%\end{array}$ & 550 & $\begin{array}{c}77,2 \\
\%\end{array}$ & 712 & $100,0 \%$ \\
\hline $\begin{array}{l}\text { Planejo atividades em que preciso utilizar o } \\
\text { computador. }\end{array}$ & 139 & $\begin{array}{c}19,5 \\
\%\end{array}$ & 573 & $\begin{array}{c}80,5 \\
\%\end{array}$ & 712 & $100,0 \%$ \\
\hline $\begin{array}{l}\text { Realizo atividades de criação/edição de vídeo } \\
\text { com os alunos. }\end{array}$ & 165 & $\begin{array}{c}23,2 \\
\%\end{array}$ & 547 & $\begin{array}{c}76,8 \\
\%\end{array}$ & 712 & $100,0 \%$ \\
\hline $\begin{array}{l}\text { Utilizo a internet para aprender novas } \\
\text { metodologias de ensino. }\end{array}$ & 137 & $\begin{array}{c}19,2 \\
\%\end{array}$ & 575 & $\begin{array}{c}80,8 \\
\%\end{array}$ & 712 & $100,0 \%$ \\
\hline $\begin{array}{l}\text { Supervisiono as pesquisas que os alunos fazem } \\
\text { na internet. }\end{array}$ & 157 & $\begin{array}{c}22,1 \\
\%\end{array}$ & 555 & $\begin{array}{c}77,9 \\
\%\end{array}$ & 712 & $100,0 \%$ \\
\hline $\begin{array}{l}\text { Planejo atividades que permitem aos alunos } \\
\text { trabalharem colaborativamente com o uso de } \\
\text { tecnologias. }\end{array}$ & 153 & $\begin{array}{c}21,5 \\
\%\end{array}$ & 559 & $\begin{array}{c}78,5 \\
\%\end{array}$ & 712 & $100,0 \%$ \\
\hline $\begin{array}{l}\text { Adoto formas de avaliação em que o aluno } \\
\text { possa apresentar uma produção por meio de } \\
\text { tecnologias. }\end{array}$ & 158 & $\begin{array}{c}22,2 \\
\%\end{array}$ & 554 & $\begin{array}{c}77,8 \\
\%\end{array}$ & 712 & $100,0 \%$ \\
\hline
\end{tabular}

Questão 17: Considerando a relação entre seu contexto de trabalho e as tecnologias, avalie.

\begin{tabular}{l|c|c|c|c}
\hline \multicolumn{1}{c|}{$\begin{array}{c}\text { Relação entre seu contexto de } \\
\text { trabalho e as tecnologias }\end{array}$} & Pouco & Às vezes & Muito & Total \\
\hline $\begin{array}{l}\text { As tecnologias estão presentes no Projeto } \\
\text { Político Pedagógico da instituição em que } \\
\text { atuo. }\end{array}$ & $144(24,9 \%)$ & $216(37,4 \%)$ & $218(37,7 \%)$ & $578(100 \%)$ \\
\hline $\begin{array}{l}\text { Surgem como temática nas reuniões de } \\
\text { professores. }\end{array}$ & $92(16 \%)$ & $250(43,6 \%)$ & $232(40,4 \%)$ & $574(100 \%)$ \\
\hline $\begin{array}{l}\text { São incentivadas no planejamento pela } \\
\text { gestão pedagógica. }\end{array}$ & $121(21,2 \%)$ & $201(35,1 \%)$ & $250(43,7 \%)$ & $572(100 \%)$ \\
\hline $\begin{array}{l}\text { Estão integradas no currículo da } \\
\text { instituição. }\end{array}$ & $158(28 \%)$ & $215(38,1 \%)$ & $192(34 \%)$ & $565(100 \%)$ \\
\hline
\end{tabular}




\begin{tabular}{l|l|l|l|l}
\hline $\begin{array}{l}\text { São compartilhadas e têm seu uso } \\
\text { pedagógico incentivados pelos } \\
\text { professores. }\end{array}$ & $139(24,5 \%)$ & $247(43,5 \%)$ & $182(32 \%)$ & $568(100 \%)$ \\
\hline $\begin{array}{l}\text { Promovo formação para o uso das } \\
\text { tecnologias na minha instituição }\end{array}$ & $258(46,7 \%)$ & $189(34,2 \%)$ & $106(19,2 \%)$ & $553(100 \%)$ \\
\hline
\end{tabular}

\begin{tabular}{|c|c|c|c|c|c|c|}
\hline \multirow{2}{*}{$\begin{array}{l}\text { Relação entre seu contexto de trabalho e as } \\
\text { tecnologias }\end{array}$} & \multicolumn{2}{|c|}{ Missing } & \multicolumn{2}{|c|}{$\begin{array}{l}\text { Casos } \\
\text { válidos }\end{array}$} & \multicolumn{2}{|c|}{ Total } \\
\hline & $\mathbf{N}$ & $\%$ & $\mathbf{N}$ & $\%$ & $\mathbf{N}$ & $\%$ \\
\hline $\begin{array}{l}\text { As tecnologias estão presentes no Projeto } \\
\text { Político Pedagógico da instituição em que atuo. }\end{array}$ & 134 & $\begin{array}{c}18,8 \\
\%\end{array}$ & 578 & $\begin{array}{c}81,2 \\
\%\end{array}$ & 712 & $100,0 \%$ \\
\hline $\begin{array}{l}\text { Surgem como temática nas reuniões de } \\
\text { professores. }\end{array}$ & 138 & $\begin{array}{c}19,4 \\
\%\end{array}$ & 574 & $\begin{array}{c}80,6 \\
\%\end{array}$ & 712 & $100,0 \%$ \\
\hline $\begin{array}{l}\text { São incentivadas no planejamento pela gestão } \\
\text { pedagógica. }\end{array}$ & 140 & $\begin{array}{c}19,7 \\
\%\end{array}$ & 572 & $\begin{array}{c}80,3 \\
\%\end{array}$ & 712 & $100,0 \%$ \\
\hline Estão integradas no currículo da instituição. & 147 & $\begin{array}{c}20,6 \\
\%\end{array}$ & 565 & $\begin{array}{c}79,4 \\
\%\end{array}$ & 712 & $100,0 \%$ \\
\hline $\begin{array}{l}\text { São compartilhadas e têm seu uso pedagógico } \\
\text { incentivados pelos professores. }\end{array}$ & 144 & $\begin{array}{c}20,2 \\
\%\end{array}$ & 568 & $\begin{array}{c}79,8 \\
\%\end{array}$ & 712 & $100,0 \%$ \\
\hline $\begin{array}{l}\text { Promovo formação para o uso das tecnologias } \\
\text { na minha instituição }\end{array}$ & 159 & $\begin{array}{c}22,3 \\
\%\end{array}$ & 553 & $\begin{array}{l}77,7 \\
\%\end{array}$ & 712 & $100,0 \%$ \\
\hline
\end{tabular}


Questão 18: Classifique em ordem de importância os Recursos Educacionais Digitais (RED) que você mais utiliza. Enumere as caixas de seleção na primeira coluna, considerando 1 como o que você mais utiliza e 10 como o que você menos utiliza.

\begin{tabular}{|c|c|c|c|c|c|c|c|c|c|c|c|c|c|c|c|c|c|c|c|c|}
\hline & \multicolumn{2}{|c|}{ Vídeos } & \multicolumn{2}{|c|}{ Textos } & \multicolumn{2}{|c|}{ Jogos } & \multicolumn{2}{|c|}{$\begin{array}{c}\text { Apresentaçõ } \\
\text { es }\end{array}$} & \multicolumn{2}{|c|}{$\begin{array}{c}\text { Simulaçõe } \\
\mathbf{s}\end{array}$} & \multicolumn{2}{|c|}{ Podcast } & \multicolumn{2}{|c|}{$\begin{array}{l}\text { Imagens/ } \\
\text { ilustrações }\end{array}$} & \multicolumn{2}{|c|}{$\begin{array}{c}\text { Objetos } \\
\text { multimídias }\end{array}$} & \multicolumn{2}{|c|}{$\begin{array}{c}\text { Planos de } \\
\text { aula }\end{array}$} & \multicolumn{2}{|c|}{$\begin{array}{c}\text { Conteúdo } \\
\text { para } \\
\text { avaliação } \\
\text { do aluno }\end{array}$} \\
\hline & $\mathbf{N}$ & $\%$ & $\mathbf{N}$ & $\%$ & $\mathbf{N}$ & $\%$ & $\mathbf{N}$ & $\%$ & $\mathbf{N}$ & $\%$ & $\mathbf{N}$ & $\%$ & $\mathbf{N}$ & $\%$ & $\mathbf{N}$ & $\%$ & $\mathbf{N}$ & $\%$ & $\mathbf{N}$ & $\%$ \\
\hline $1^{\circ}$ & 59 & 15,4 & 64 & 17,0 & 64 & 17,0 & 37 & 9,8 & 20 & 5,3 & 45 & 11,3 & 51 & 14,0 & 26 & 6,7 & 81 & 21,5 & 34 & 9,0 \\
\hline $2^{\circ}$ & 71 & 18,6 & 54 & 14,3 & 54 & 14,3 & 43 & 11,4 & 29 & 7,7 & 17 & 4,3 & 55 & 15,2 & 25 & 6,5 & 34 & 9,0 & 30 & 7,9 \\
\hline $3^{\circ}$ & 48 & 12,6 & 47 & 12,5 & 47 & 12,5 & 55 & 14,6 & 29 & 7,7 & 13 & 3,3 & 54 & 14,9 & 38 & 9,8 & 27 & 7,2 & 47 & 12,4 \\
\hline $4^{\circ}$ & 41 & 10,7 & 37 & 9,8 & 37 & 9,8 & 39 & 10,4 & 21 & 5,6 & 17 & 4,3 & 48 & 13,2 & 54 & 14,0 & 31 & 8,2 & 46 & 12,2 \\
\hline $5^{\circ}$ & 31 & 8,1 & 35 & 9,3 & 35 & 9,3 & 46 & 12,2 & 35 & 9,3 & 22 & 5,5 & 42 & 11,6 & 51 & 13,2 & 45 & 11,9 & 56 & 14,8 \\
\hline $6^{\circ}$ & 21 & 5,5 & 47 & 12,5 & 47 & 12,5 & 50 & 13,3 & 33 & 8,7 & 15 & 3,8 & 31 & 8,5 & 38 & 9,8 & 38 & 10,1 & 42 & 11,1 \\
\hline $7^{\circ}$ & 26 & 6,8 & 29 & 7,7 & 29 & 7,7 & 40 & 10,6 & 41 & 10,8 & 9 & 2,3 & 22 & 6,1 & 54 & 14,0 & 43 & 11,4 & 39 & 10,3 \\
\hline $8^{\circ}$ & 34 & 8,9 & 23 & 6,1 & 23 & 6,1 & 28 & 7,4 & 49 & 13,0 & 39 & 9,8 & 24 & 6,6 & 49 & 12,7 & 26 & 6,9 & 38 & 10,1 \\
\hline $9^{\circ}$ & 28 & 7,3 & 20 & 5,3 & 20 & 5,3 & 21 & 5,6 & 71 & 18,8 & 60 & 15,1 & 13 & 3,6 & 35 & 9,1 & 31 & 8,2 & 24 & 6,3 \\
\hline $10^{\circ}$ & 23 & 6,0 & 21 & 5,6 & 21 & 5,6 & 17 & 4,5 & 50 & 13,2 & 161 & 40,5 & 23 & 6,3 & 16 & 4,1 & 21 & 5,6 & 22 & 5,8 \\
\hline Total & 382 & $\begin{array}{c}100, \\
0\end{array}$ & 377 & $\begin{array}{c}100 \\
0\end{array}$ & 377 & $\begin{array}{c}100, \\
0\end{array}$ & 376 & 100,0 & 378 & $\begin{array}{c}100, \\
0\end{array}$ & 398 & $\begin{array}{c}100 \\
0\end{array}$ & 363 & $\begin{array}{c}100, \\
0\end{array}$ & 386 & $\begin{array}{c}100 \\
0\end{array}$ & $\begin{array}{c}37 \\
7 \\
\end{array}$ & $\begin{array}{c}100 \\
0\end{array}$ & 378 & $\begin{array}{c}100 \\
0\end{array}$ \\
\hline $\begin{array}{c}\text { Missin } \\
g\end{array}$ & 330 & 46,3 & 335 & 47,1 & 335 & 47,1 & 336 & 47,2 & 334 & 46,9 & 314 & 44,1 & 349 & 49,0 & 326 & 45,8 & $\begin{array}{c}33 \\
5\end{array}$ & 47,1 & 334 & 46,9 \\
\hline
\end{tabular}


Questão 18: Recursos Educacionais Digitais (RED) por ordem de importância.

\begin{tabular}{|c|c|c|}
\hline & $\mathbf{N}$ & $\%$ \\
\hline $1^{\circ}$ - Planos de aula & 81 & 21,5 \\
\hline $2^{\circ}$ - Vídeos & 71 & 18,6 \\
\hline $3^{\circ}$ - Imagens / ilustrações & 54 & 14,9 \\
\hline $4^{\circ}$ - Objetos multimídias & 54 & 14,0 \\
\hline $\begin{array}{l}5^{\circ} \text { - Conteúdo para } \\
\text { avaliação do aluno }\end{array}$ & 56 & 14,8 \\
\hline $6^{\circ}$ - Apresentações & 50 & 13,3 \\
\hline $7^{\circ}$ - Objetos multimídias & 54 & 14,0 \\
\hline $8^{\circ}$ - Simulações & 49 & 13,0 \\
\hline $9^{\circ}$ - Simulações & 71 & 18,8 \\
\hline $10^{\circ}$ - Podcast & 161 & 40,5 \\
\hline Total & & \\
\hline
\end{tabular}

Questão 19: Indique seu grau de concordância com os Recursos Educacionais Digitais (RED) a partir dos itens a seguir:

\begin{tabular}{|c|c|c|c|c|}
\hline $\begin{array}{l}\text { Grau de concordância com os } \\
\text { Recursos Educacionais Digitais (RED) }\end{array}$ & Discordo & $\begin{array}{l}\text { Nem } \\
\text { discordol } \\
\text { Nem } \\
\text { concordo }\end{array}$ & Concordo & Total \\
\hline $\begin{array}{l}\text { As atividades pedagógicas com os } \\
\text { recursos influenciam o professor a adotar } \\
\text { novos métodos pedagógicos. }\end{array}$ & $6(1,2 \%)$ & $59(11,9 \%)$ & $\begin{array}{c}432 \\
(86,9 \%)\end{array}$ & $497(100 \%)$ \\
\hline $\begin{array}{l}\text { Consigo inserir os RED no meu } \\
\text { planejamento de ensino. }\end{array}$ & $17(3,4 \%)$ & $111(22,3 \%)$ & $\begin{array}{c}369 \\
(74,2 \%)\end{array}$ & $497(100 \%)$ \\
\hline $\begin{array}{l}\text { As práticas com os RED dependem da } \\
\text { experiência prévia com o uso das } \\
\text { tecnologias. }\end{array}$ & $21(4,2 \%)$ & $98(19,7 \%)$ & $\begin{array}{c}378 \\
(76,1 \%)\end{array}$ & $497(100 \%)$ \\
\hline $\begin{array}{l}\text { Aumentam a motivação dos alunos para } \\
\text { aprender. }\end{array}$ & $8(1,6 \%)$ & $102(20,6 \%)$ & $\begin{array}{c}386 \\
(77,8 \%)\end{array}$ & $496(100 \%)$ \\
\hline $\begin{array}{l}\text { Promovem novas oportunidades para os } \\
\text { alunos que não aprendem com métodos } \\
\text { tradicionais. }\end{array}$ & $5(1 \%)$ & $77(15,4 \%)$ & $\begin{array}{c}417 \\
(83,6 \%)\end{array}$ & $499(100 \%)$ \\
\hline $\begin{array}{l}\text { Os alunos ficam mais interessados nas } \\
\text { aulas em que há atividades com RED. }\end{array}$ & $9(1,8 \%)$ & $89(17,9 \%)$ & $\begin{array}{c}398 \\
(80,2 \%)\end{array}$ & $496(100 \%)$ \\
\hline $\begin{array}{l}\text { As práticas com os RED dependem da } \\
\text { formação do professor. }\end{array}$ & $84(16,8 \%)$ & $129(25,7 \%)$ & $\begin{array}{c}288 \\
(57,5 \%)\end{array}$ & $501(100 \%)$ \\
\hline
\end{tabular}




\begin{tabular}{l|c|c|c|c}
\hline $\begin{array}{l}\text { O uso dos RED motiva os professores a } \\
\text { repensarem sua prática pedagógica. }\end{array}$ & $13(2,6 \%)$ & $96(19,2 \%)$ & $\begin{array}{c}391 \\
(78,2 \%)\end{array}$ & $500(100 \%)$ \\
\hline Utilizo RED porque os alunos solicitam. & $\begin{array}{c}174 \\
(35,1 \%)\end{array}$ & $230(46,4 \%)$ & $92(18,5 \%)$ & $496(100 \%)$ \\
\hline $\begin{array}{l}\text { Minhas aulas ficaram mais interessantes } \\
\text { quando passei a utilizar os RED. }\end{array}$ & $11(2,2 \%)$ & $109(21,9 \%)$ & $\begin{array}{c}378 \\
(75,9 \%)\end{array}$ & $498(100 \%)$ \\
\hline $\begin{array}{l}\text { As práticas com os RED dependem do } \\
\text { tempo de experiência com o professor. }\end{array}$ & $104(21 \%)$ & $193(39 \%)$ & $198(40 \%)$ & $495(100 \%)$ \\
\hline
\end{tabular}

\begin{tabular}{l|c|c|c|c|c|c}
\hline \multicolumn{1}{c}{$\begin{array}{c}\text { Grau de concordância com os Recursos } \\
\text { Educacionais Digitais (RED) }\end{array}$} & \multicolumn{2}{|c|}{ Missing } & \multicolumn{2}{|c}{$\begin{array}{c}\text { Casos } \\
\text { válidos }\end{array}$} & \multicolumn{2}{c}{ Total } \\
\cline { 2 - 7 } & $\mathbf{N}$ & $\%$ & $\mathbf{N}$ & $\%$ & $\mathbf{N}$ & $\%$ \\
\hline $\begin{array}{l}\text { As atividades pedagógicas com os recursos } \\
\text { influenciam o professor a adotar novos métodos } \\
\text { pedagógicos. }\end{array}$ & 215 & $\begin{array}{c}30,2 \\
\%\end{array}$ & 497 & $\begin{array}{c}69,8 \\
\%\end{array}$ & 712 & $100,0 \%$ \\
\hline $\begin{array}{l}\text { Consigo inserir os RED no meu planejamento } \\
\text { de ensino. }\end{array}$ & 215 & $\begin{array}{c}30,2 \\
\%\end{array}$ & 497 & $\begin{array}{c}69,8 \\
\%\end{array}$ & 712 & $100,0 \%$ \\
\hline $\begin{array}{l}\text { As práticas com os RED dependem da } \\
\text { experiência prévia com o uso das tecnologias. }\end{array}$ & 215 & $\begin{array}{c}30,2 \\
\%\end{array}$ & 497 & $\begin{array}{c}69,8 \\
\%\end{array}$ & 712 & $100,0 \%$ \\
\hline $\begin{array}{l}\text { Aumentam a motivação dos alunos para } \\
\text { aprender. }\end{array}$ & 216 & $\begin{array}{c}30,3 \\
\%\end{array}$ & 496 & $\begin{array}{c}69,7 \\
\%\end{array}$ & 712 & $100,0 \%$ \\
\hline $\begin{array}{l}\text { Promovem novas oportunidades para os alunos } \\
\text { que não aprendem com métodos tradicionais. }\end{array}$ & 213 & $\begin{array}{c}29,9 \\
\%\end{array}$ & 499 & $\begin{array}{c}70,1 \\
\%\end{array}$ & 712 & $100,0 \%$ \\
\hline $\begin{array}{l}\text { Os alunos ficam mais interessados nas aulas } \\
\text { em que há atividades com RED. }\end{array}$ & 216 & $\begin{array}{c}30,3 \\
\%\end{array}$ & 496 & $\begin{array}{c}69,7 \\
\%\end{array}$ & 712 & $100,0 \%$ \\
\hline $\begin{array}{l}\text { As práticas com os RED dependem da } \\
\text { formação do professor. }\end{array}$ & 211 & $\begin{array}{c}29,6 \\
\%\end{array}$ & 501 & $\begin{array}{c}70,4 \\
\%\end{array}$ & 712 & $100,0 \%$ \\
\hline $\begin{array}{l}\text { O uso dos RED motiva os professores a } \\
\text { repensarem sua prática pedagógica. }\end{array}$ & 212 & $\begin{array}{c}29,8 \\
\%\end{array}$ & 500 & $\begin{array}{c}70,2 \\
\%\end{array}$ & 712 & $100,0 \%$ \\
\hline Utilizo RED porque os alunos solicitam. & 216 & $\begin{array}{c}30,3 \\
\%\end{array}$ & 496 & $\begin{array}{c}69,7 \\
\%\end{array}$ & 712 & $100,0 \%$ \\
\hline $\begin{array}{l}\text { Minhas aulas ficaram mais interessantes } \\
\text { quando passei a utilizar os RED. }\end{array}$ & $\begin{array}{c}30,1 \\
\%\end{array}$ & $\begin{array}{c}69,9 \\
\%\end{array}$ & 712 & $100,0 \%$ \\
\hline $\begin{array}{l}\text { As práticas com os RED dependem do tempo } \\
\text { de experiência com o professor. }\end{array}$ & 217 & 712 & $100,0 \%$ \\
\hline
\end{tabular}


Questão 20: Aponte sua relação com os Recursos Educacionais Digitais (RED)

\begin{tabular}{l|c|c|c|c}
\hline \multicolumn{1}{c|}{\begin{tabular}{c}
\multicolumn{1}{c|}{ Relação com os Recursos } \\
Educacionais Digitais (RED)
\end{tabular}} & Pouco & Às vezes & Muito & Total \\
\hline $\begin{array}{l}\text { Recomendo RED para outros professores } \\
\text { na minha instituição. }\end{array}$ & $48(9,8 \%)$ & $185(37,8 \%)$ & $\begin{array}{c}257 \\
(52,4 \%)\end{array}$ & $490(100 \%)$ \\
\hline $\begin{array}{l}\text { Participo de fórum ou de redes sociais } \\
\text { sobre práticas pedagógicas com RED. }\end{array}$ & $\begin{array}{c}148 \\
(30,4 \%)\end{array}$ & $217(44,6 \%)$ & $\begin{array}{c}122 \\
(25,1 \%)\end{array}$ & $487(100 \%)$ \\
\hline $\begin{array}{l}\text { Utilizo RED recomendados por outros } \\
\text { professores ou pela coordenação } \\
\text { pedagógica. }\end{array}$ & $62(12,8 \%)$ & $208(43,1 \%)$ & $\begin{array}{c}213 \\
(44,1 \%)\end{array}$ & $483(100 \%)$ \\
\hline $\begin{array}{l}\text { Já participei de alguma formação que } \\
\text { tenha abordado o tema dos recursos } \\
\text { educacionais. }\end{array}$ & $78(16,1 \%)$ & $155(32 \%)$ & $\begin{array}{c}251 \\
(51,9 \%)\end{array}$ & $484(100 \%)$ \\
\hline $\begin{array}{l}\text { Mantenho algum blog, canal ou página } \\
\text { em que divulgo minhas praticas com }\end{array}$ & $\begin{array}{c}370 \\
\text { RED. }\end{array}$ & $65(14 \%)$ & $30(6,5 \%)$ & $465(100 \%)$ \\
\hline $\begin{array}{l}\text { Costumo acessar os RED por meio de } \\
\text { repositórios (Portal do Professor, }\end{array}$ & $\begin{array}{l}121 \\
\text { Educopédia, Edumatec). }\end{array}$ & $190(39,4 \%)$ & $\begin{array}{c}171 \\
(35,5 \%)\end{array}$ & $482(100 \%)$ \\
\hline $\begin{array}{l}\text { Costumo acessar RED por meio de sites } \\
\text { de busca como o Google. }\end{array}$ & $43(8,8 \%)$ & $125(25,6 \%)$ & $\begin{array}{c}320 \\
(65,6 \%)\end{array}$ & $488(100 \%)$ \\
\hline
\end{tabular}

\begin{tabular}{l|c|c|c|c|c|c}
\hline \multicolumn{1}{|c|}{$\begin{array}{l}\text { Relação com os Recursos Educacionais } \\
\text { Digitais (RED) }\end{array}$} & \multicolumn{2}{|c|}{ Missing } & \multicolumn{2}{c|}{$\begin{array}{c}\text { Casos } \\
\text { válidos }\end{array}$} & \multicolumn{2}{c}{ Total } \\
\cline { 2 - 7 } & $\mathbf{N}$ & $\%$ & $\mathbf{N}$ & $\%$ & $\mathbf{N}$ & $\%$ \\
\hline $\begin{array}{l}\text { Recomendo RED para outros professores na } \\
\text { minha instituição. }\end{array}$ & 222 & $\begin{array}{c}31,2 \\
\%\end{array}$ & 490 & $\begin{array}{c}68,8 \\
\%\end{array}$ & 712 & $100,0 \%$ \\
\hline $\begin{array}{l}\text { Participo de fórum ou de redes sociais sobre } \\
\text { práticas pedagógicas com RED. }\end{array}$ & 225 & $\begin{array}{c}31,6 \\
\%\end{array}$ & 487 & $\begin{array}{c}68,4 \\
\%\end{array}$ & 712 & $100,0 \%$ \\
\hline $\begin{array}{l}\text { Utilizo RED recomendados por outros } \\
\text { professores ou pela coordenação pedagógica. }\end{array}$ & 229 & $\begin{array}{c}32,2 \\
\%\end{array}$ & 483 & $\begin{array}{c}67,8 \\
\%\end{array}$ & 712 & $100,0 \%$ \\
\hline $\begin{array}{l}\text { Já participei de alguma formação que tenha } \\
\text { abordado o tema dos recursos educacionais. }\end{array}$ & 228 & $\begin{array}{c}32,0 \\
\%\end{array}$ & 484 & $\begin{array}{c}68,0 \\
\%\end{array}$ & 712 & $100,0 \%$ \\
\hline $\begin{array}{l}\text { Mantenho algum blog, canal ou página em que } \\
\text { divulgo minhas praticas com RED. }\end{array}$ & 247 & $\begin{array}{c}34,7 \\
\%\end{array}$ & 465 & $\begin{array}{c}65,3 \\
\%\end{array}$ & 712 & $100,0 \%$ \\
\hline $\begin{array}{l}\text { Costumo acessar os RED por meio de } \\
\text { repositórios (Portal do Professor, Educopédia, }\end{array}$ & 230 & $\begin{array}{c}32,3 \\
\text { Edumatec). }\end{array}$ & 482 & $\begin{array}{c}67,7 \\
\%\end{array}$ & 712 & $100,0 \%$ \\
\hline $\begin{array}{l}\text { Costumo acessar RED por meio de sites de } \\
\text { busca como o Google. }\end{array}$ & 224 & $\begin{array}{c}31,5 \\
\%\end{array}$ & 488 & $\begin{array}{c}68,5 \\
\%\end{array}$ & 712 & $100,0 \%$ \\
\hline
\end{tabular}


Questão 21: Analise suas práticas com os Recursos Educacionais Digitais (RED)

\begin{tabular}{l|c|c|c|c}
\hline \multicolumn{1}{c|}{$\begin{array}{c}\text { Práticas com os Recursos } \\
\text { Educacionais Digitais (RED) }\end{array}$} & Pouco & Às vezes & Muito & Total \\
\hline $\begin{array}{l}\text { Produzo RED para serem usados em sala } \\
\text { de aula. }\end{array}$ & $158(33 \%)$ & $213(44,5 \%)$ & $\begin{array}{c}108 \\
(22,5 \%)\end{array}$ & $479(100 \%)$ \\
\hline $\begin{array}{l}\text { Realizo adaptações de RED encontrados } \\
\text { em repositórios. }\end{array}$ & $\begin{array}{c}127 \\
(26,4 \%)\end{array}$ & $241(50,1 \%)$ & $\begin{array}{c}113 \\
(23,5 \%)\end{array}$ & $481(100 \%)$ \\
\hline Crio RED em conjunto com os alunos. & $304(64 \%)$ & $136(28,6 \%)$ & $35(7,4 \%)$ & $475(100 \%)$ \\
\hline $\begin{array}{l}\text { Elaboro RED a partir da combinação com } \\
\text { outros recursos. }\end{array}$ & $\begin{array}{c}164 \\
(34,2 \%)\end{array}$ & $228(47,5 \%)$ & $88(18,3 \%)$ & $480(100 \%)$ \\
\hline $\begin{array}{l}\text { Produzo estratégias de aprendizagem } \\
\text { com RED. }\end{array}$ & $\begin{array}{c}117 \\
(24,3 \%)\end{array}$ & $224(46,5 \%)$ & $\begin{array}{c}141 \\
(29,3 \%)\end{array}$ & $482(100 \%)$ \\
\hline $\begin{array}{l}\text { Desenvolvo RED em parceria com outros } \\
\text { professores. }\end{array}$ & $\begin{array}{c}257 \\
(54,3 \%)\end{array}$ & $168(35,5 \%)$ & $48(10,1 \%)$ & $473(100 \%)$ \\
\hline $\begin{array}{l}\text { Compartilho RED de minha autoria } \\
\text { enviando-os para repositórios. }\end{array}$ & $\begin{array}{c}337 \\
(72,9 \%)\end{array}$ & $103(22,3 \%)$ & $22(4,8 \%)$ & $462(100 \%)$ \\
\hline $\begin{array}{l}\text { Reuso um mesmo RED em diferentes } \\
\text { contextos pedagógicos. }\end{array}$ & $\begin{array}{c}117 \\
(24,4 \%)\end{array}$ & $250(52,2 \%)$ & $\begin{array}{c}112 \\
(23,4 \%)\end{array}$ & $479(100 \%)$ \\
\hline
\end{tabular}

\begin{tabular}{|c|c|c|c|c|c|c|}
\hline \multirow{2}{*}{$\begin{array}{c}\text { Práticas com os Recursos Educacionais } \\
\text { Digitais (RED) }\end{array}$} & \multicolumn{2}{|c|}{ Missing } & \multicolumn{2}{|c|}{$\begin{array}{l}\text { Casos } \\
\text { válidos }\end{array}$} & \multicolumn{2}{|c|}{ Total } \\
\hline & $\mathbf{N}$ & $\%$ & $\mathbf{N}$ & $\%$ & $\mathbf{N}$ & $\%$ \\
\hline $\begin{array}{l}\text { Produzo RED para serem usados em sala de } \\
\text { aula. }\end{array}$ & 233 & $\begin{array}{c}32,7 \\
\%\end{array}$ & 479 & $\begin{array}{c}67,3 \\
\%\end{array}$ & 712 & $100,0 \%$ \\
\hline $\begin{array}{l}\text { Realizo adaptações de RED encontrados em } \\
\text { repositórios. }\end{array}$ & 231 & $\begin{array}{c}32,4 \\
\%\end{array}$ & 481 & $\begin{array}{c}67,6 \\
\%\end{array}$ & 712 & $100,0 \%$ \\
\hline Crio RED em conjunto com os alunos. & 237 & $\begin{array}{c}33,3 \\
\%\end{array}$ & 475 & $\begin{array}{c}66,7 \\
\%\end{array}$ & 712 & $100,0 \%$ \\
\hline $\begin{array}{l}\text { Elaboro RED a partir da combinação com outros } \\
\text { recursos. }\end{array}$ & 232 & $\begin{array}{c}32,6 \\
\%\end{array}$ & 480 & $\begin{array}{c}67,4 \\
\%\end{array}$ & 712 & $100,0 \%$ \\
\hline $\begin{array}{l}\text { Produzo estratégias de aprendizagem com } \\
\text { RED. }\end{array}$ & 230 & $\begin{array}{c}32,3 \\
\%\end{array}$ & 482 & $\begin{array}{c}67,7 \\
\%\end{array}$ & 712 & $100,0 \%$ \\
\hline $\begin{array}{l}\text { Desenvolvo RED em parceria com outros } \\
\text { professores. }\end{array}$ & 239 & $\begin{array}{c}33,6 \\
\%\end{array}$ & 473 & $\begin{array}{c}66,4 \\
\%\end{array}$ & 712 & $100,0 \%$ \\
\hline $\begin{array}{l}\text { Compartilho RED de minha autoria enviando-os } \\
\text { para repositórios. }\end{array}$ & 250 & $\begin{array}{c}35,1 \\
\%\end{array}$ & 462 & $\begin{array}{c}64,9 \\
\%\end{array}$ & 712 & $100,0 \%$ \\
\hline $\begin{array}{l}\text { Reuso um mesmo RED em diferentes contextos } \\
\text { pedagógicos. }\end{array}$ & 233 & $\begin{array}{c}32,7 \\
\%\end{array}$ & 479 & $\begin{array}{c}67,3 \\
\%\end{array}$ & 712 & $100,0 \%$ \\
\hline
\end{tabular}




\section{Apêndice IV - Análises Bivariadas}

\section{Questões de investigação para a análise de correlação:}

Que níveis de correlação existe entre as dimensões 1 a 6 e a A?

Que níveis de correlação existe entre as dimensões 1 a 6 e a B?

\section{Procedimentos:}

1) Criação dos construtos

2) Cálculo da média de cada respondente

\section{3) Análise Bivariada de correlação}

\section{- Criação dos construtos de por agrupamento dos itens/indicadores}

Para formação de cada construto foram selecionados um conjunto de indicadores. Após a formação dos construtos seguimos para a recodificação das respostas de cada inquirido. Nesse sentido, recodificamos as respostas seguindo o padrão: respostas nominais de "pouco" ou "não concordo" foram substituídas pelo numeral 1; respostas nominais de "às vezes" ou "não concordo/ nem discordo" foram substituídas pelo numeral 2; respostas nominais de "muito" ou "concordo" foram substituídas pelo numeral 3 . A tabela 5 demonstra o processo na formação do construto.

1) Uso pessoal das TIC (Questão 16)

Desenvolvo atividades no computador que requerem noções de programação.

Modifico conteúdos disponibilizados na internet

Realizo downloads e instalo programas ou aplicativos.

Compartilho na internet conteúdos (imagens, vídeos, textos) de autoria própria

Realizo edição de imagem.

Realizo edição de vídeo.

2) Uso das TIC na prática pedagógica (Questão 16)

Utilizo o ambiente virtual de aprendizagem (Moodle, Google Classroom) para criar atividades com os alunos (wikis, fóruns, tarefas).

Desenvolvo trabalhos de produção midiática com os alunos

Planejo atividades em que preciso utilizar o computador

Realizo atividades de criação/edição de vídeo com os alunos.

Utilizo a internet para aprender novas metodologias de ensino. 
Supervisiono as pesquisas que os alunos fazem na internet.

Planejo atividades que permitem aos alunos trabalharem colaborativamente com o uso de tecnologias.

Adoto formas de avaliação em que o aluno possa apresentar uma produção por meio de tecnologias.

3) Uso das TIC na gestão pedagógica (Questão 17)

As tecnologias estão presentes no Projeto Político Pedagógico da instituição em que atuo.

Surgem como temática nas reuniões de professores.

São incentivadas no planejamento pela gestão pedagógica.

Estão integradas no currículo da instituição.

São compartilhadas e têm seu uso pedagógico incentivados pelos professores.

Promovo formação para o uso das tecnologias na minha instituição.

4) Atitude sobre os Recursos educacionais digitais (Questão 19)

As atividades pedagógicas com os recursos influenciam o professor a adotar novos métodos pedagógicos.

As práticas com os RED dependem da experiência prévia com o uso das tecnologias. Aumentam a motivação dos alunos para aprender.

Promovem novas oportunidades para os alunos que não aprendem com métodos tradicionais.

Os alunos ficam mais interessados nas aulas em que há atividades com RED.

O uso dos RED motiva os professores a repensarem sua prática pedagógica.

Minhas aulas ficaram mais interessantes quando passei a utilizar os RED.

5) Contexto Tecnológico (Questão 14)

Para a dimensão contexto tecnológico, em função das respostas de cada professor atribuiu-se um nível de acordo com as tecnologias disponibilizadas por diferentes iniciativas nacionais relacionadas com o uso das TIC em contexto educativo abaixo indicadas, onde:

- Televisão e vídeo (Prolnfo) atribuiu-se o valor 1

- As tecnologias anteriores mais Laboratório de informática, projetor portátil (computador e projetor integrados) e internet banda larga (Prolnfo integrado) atribuiu-se o valor 2 As tecnologias anteriores mais o Laptop (UCA) atribuiu-se o valor 3 
A) Práticas de autoria de Recursos Educacionais Digitais (Questão 21)

Produzo RED para serem usados em sala de aula.

Realizo adaptações de RED encontrados em repositórios.

Crio RED em conjunto com os alunos.

Elaboro RED a partir da combinação com outros recursos.

Produzo estratégias de aprendizagem com RED.

Desenvolvo RED em parceria com outros professores.

Compartilho RED de minha autoria enviando-os para repositórios

Reuso um mesmo RED em diferentes contextos pedagógicos.

B) Prática de compartilhamento de RED (Questão 20)

Recomendo RED para outros professores na minha instituição.

Participo de fórum ou de redes sociais sobre práticas pedagógicas com RED

Utilizo RED recomendados por outros professores ou pela coordenação pedagógica

Mantenho algum blog, canal ou página em que divulgo minhas práticas com RED.

Costumo acessar os RED por meio de repositórios (Portal do Professor, Educopédia, Edumatec).

Costumo acessar RED por meio de sites de busca como o Google

\section{- Cálculo da média de cada respondente}

Procedimento realizado no software excel (acesso ao arquivo) em que se calculou a média dos itens que formaram cada dimensão de análise. Com os resultados de cada dimensão e por respondente foi possível realizar as análises bivariadas $d$ a média dos indicadores origina os dados do construto e posteriormente foi utilizada para o cálculo de coeficiente de correlação. Após a criação de cada construto seguido das médias de cada respondente foram realizados os cálculos do coeficiente de correlação de Pearson seguindo as questões de investigação para a análise de correlação.

\section{- Resultados da análise da correlação:}

Foram realizadas análise de correlação dos construtos das variáveis dependentes (Práticas de autoria de Recursos Educacionais Digitais; Práticas de compartilhamento de RED) com as variáveis independentes (Uso pessoal das TIC; Uso 
das TIC na prática pedagógica; Uso das TIC na gestão pedagógica; Atitude relativa aos Recursos educacionais digitais; Contexto tecnológico) e obtivemos os seguintes resultados:

\begin{tabular}{|l|l|l|}
\hline & $\begin{array}{l}\text { Práticas de autoria de } \\
\text { Recursos Educacionais } \\
\text { Digitais }\end{array}$ & $\begin{array}{c}\text { Práticas de } \\
\text { compartilhamento } \\
\text { de RED }\end{array}$ \\
\hline Uso pessoal das TIC & $\begin{array}{l}0,4950965 \\
\text { Moderada }\end{array}$ & $\begin{array}{l}0,14215431 \\
\text { Muito baixa }\end{array}$ \\
\hline $\begin{array}{l}\text { Uso das TIC na prática } \\
\text { pedagógica }\end{array}$ & $\begin{array}{l}0,54991995 \\
\text { Moderada }\end{array}$ & $\begin{array}{l}0,23234395 \\
\text { Baixa }\end{array}$ \\
\hline $\begin{array}{l}\text { Uso das TIC na gestão } \\
\text { pedagógica }\end{array}$ & 0,32552468 & 0,22565455 \\
Baixa & Muito baixa \\
\hline $\begin{array}{l}\text { Atitude relativa aos } \\
\text { Recursos educacionais } \\
\text { digitais }\end{array}$ & 0,263717 & 0,9648877 \\
\hline Contexto tecnológico & 0,16317232 & Muito alta \\
\hline & Muito baixa & 0,10021166 \\
Muito baixa
\end{tabular}




\section{Apêndice V - Protocolo para o Grupo Focal On-line}

\section{Questões de estudo:}

Como são utilizados os recursos educacionais digitais por professores nos seus contextos profissionais?

Em que medida o uso de recursos educacionais digitais contribui para o desenvolvimento de práticas autorais do professor?

\begin{tabular}{|c|c|}
\hline \multicolumn{2}{|c|}{ Bloco A - Apresentação e introdução ao grupo focal } \\
\hline Objetivo & Perguntas Norteadoras \\
\hline Iniciar a interação & $\begin{array}{l}\text { Apresentação da pesquisadora e da observadora; } \\
\text { Solicitar que os participantes se apresentem e fale } \\
\text { rapidamente sobre o seu percurso profissional e } \\
\text { formação. }\end{array}$ \\
\hline $\begin{array}{l}\text { Esclarecer } \\
\text { questões éticas e } \\
\text { obter autorização }\end{array}$ & $\begin{array}{l}\text { Explicar que o grupo focal será gravado e que a } \\
\text { observadora tomará notas. } \\
\text { Esclarecer questões de anonimato da pesquisa }\end{array}$ \\
\hline $\begin{array}{lr}\text { Explicar } & \text { os } \\
\text { objetivos } & \text { da } \\
\text { pesquisa e do } \\
\text { grupo focal. } \\
-\quad \text { Incentivar os } \\
\text { participantes à uma } \\
\text { comunicação } \\
\text { sincera } \\
\text { espontânea. }\end{array}$ & $\begin{array}{l}\text { - Relembrar os objetivos da pesquisa } \\
\text { - solicitar que os participantes tomem nota das suas } \\
\text { respostas, tendo em vista a validação da entrevista no } \\
\text { final. } \\
\text { - Explicar o tratamento dos dados provenientes do } \\
\text { questionário inicial e como ocorreu a triagem para a } \\
\text { escolha dos participantes. }\end{array}$ \\
\hline \multicolumn{2}{|c|}{ Bloco B - Exploração do tema autoria docente e RED } \\
\hline 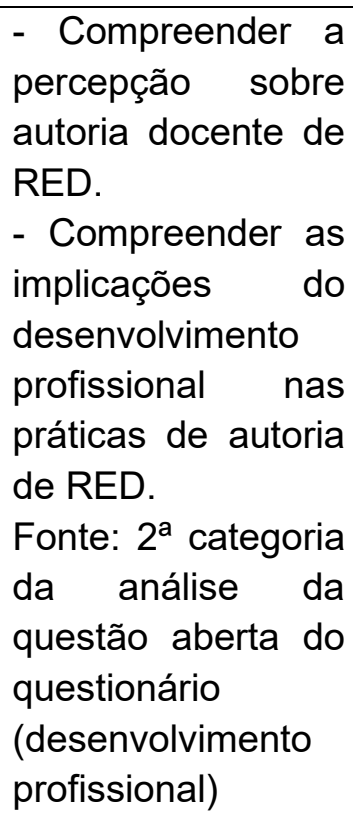 & $\begin{array}{l}\text { 1) O que considera ser autoria de RED? } \\
\text { 2) Você se considera um professor autor? } \\
\text { - Concepção de autoria. } \\
\text { - Motivações/razões que o levam a ser autor } \\
\text { 2) Que implicações tem o seu desenvolvimento } \\
\text { profissional para a autoria docente? } \\
\text { - Caminho percorrido (formação, incentivos externos, } \\
\text { trabalho colaborativo, necessidade de inovar/alterar } \\
\text { práticas de ensino... }\end{array}$ \\
\hline
\end{tabular}




\begin{tabular}{|c|c|}
\hline $\begin{array}{l}- \text { Conhecer as } \\
\text { práticas autorais de } \\
\text { RED realizadas } \\
\text { pelos professores. } \\
\text { Fonte: } 1^{\circ} \text { e } 3^{\text {a }} \\
\text { categorias da } \\
\text { análise da questão } \\
\text { aberta do } \\
\text { questionário } \\
\text { (aprendizagem, } \\
\text { inserção na cultura } \\
\text { digital) }\end{array}$ & $\begin{array}{l}\text { 3) Quais são as suas práticas autorais de RED? } \\
\text { Quais tipos de recursos são criados? Quando, porquê e } \\
\text { para quê? } \\
\text { (fatores e motivos para a criação de RED) } \\
\text { Quais tipos modificação vocês costumam realizar com } \\
\text { os recursos educacionais? } \\
\text { Tipos de mídias utilizadas para a criação de recursos. } \\
\text { Graus de autoria (adaptação, recurso novo, remix) os } \\
\text { processos de autoria se manifestam em sua prática } \\
\text { pedagógica }\end{array}$ \\
\hline $\begin{array}{l}- \text { Conhecer as } \\
\text { competências } \\
\text { digitais dos } \\
\text { professores e sua } \\
\text { possível relação } \\
\text { com a autoria de } \\
\text { RED. } \\
\text { Fonte: } 2^{\text {a }} \text { categoria } \\
\text { da análise da } \\
\text { questão aberta do } \\
\text { questionário } \\
\text { (desenvolvimento } \\
\text { profissional) }\end{array}$ & $\begin{array}{l}\text { 4) Como você classificaria as suas competências } \\
\text { digitais? } \\
\text { Faça a sua reflexão tendo em conta o referêncial } \\
\text { DigCompEdu } \\
\text { (dar oportunidade aos professores de contactarem com o } \\
\text { referêncial) } \\
\text { 5) Que competências digitais mobiliza na criação ou } \\
\text { adaptação de RED? Quais e como? } \\
\text { - Relação entre competência digital e autoria de recursos. }\end{array}$ \\
\hline $\begin{array}{l}\text { Explorar as } \\
\text { possíveis relações } \\
\text { entre criatividade e } \\
\text { autoria. } \\
\text { Fonte: Item 2.3.3. - } \\
\text { Origens da Autoria } \\
\text { Docente }\end{array}$ & $\begin{array}{l}\text { 6) Que implicações tem a criatividade docente nas } \\
\text { práticas de autoria de RED? }\end{array}$ \\
\hline \multicolumn{2}{|c|}{ Bloco C - Aprofundamento dos dados do questionário } \\
\hline $\begin{array}{l}\text { - Aprofundar a } \\
\text { relação entre o } \\
\text { desenvolvimento } \\
\text { profissional e o uso } \\
\text { de RED. }\end{array}$ & $\begin{array}{l}\text { 7) Houve alterações nas suas práticas pedagógicas } \\
\text { depois de ter passado a utilizar os RED? } \\
\text { - Uso de recursos e possíveis mudanças da prática } \\
\text { profissional. } \\
\text { - Reflexão sobre a atividades educacionais com os } \\
\text { recurso-reflexão sobre os appeis que os alunos } \\
\text { assumem }\end{array}$ \\
\hline $\begin{array}{l}\text { - Compreender as } \\
\text { práticas } \\
\text { colaborativas e de }\end{array}$ & $\begin{array}{l}\text { 8) Compartilha RED? Onde? Porquê? } \\
\text { - Público com qual os recursos são compartilhados. } \\
\text { - Meios de compartilhamento (repositórios ou partilha }\end{array}$ \\
\hline
\end{tabular}




\begin{tabular}{|c|c|}
\hline $\begin{array}{l}\text { compartilhamento } \\
\text { de um recurso }\end{array}$ & $\begin{array}{l}\text { pessoal - email, FaceBook...) } \\
\text { 9) Que práticas de autoria colaborativa desenvolve? Com } \\
\text { quem? } \\
\text { - Motivações para adotar essa metodologia no processo } \\
\text { de autoria. Colaboração com pares, alunos, empresas... }\end{array}$ \\
\hline $\begin{array}{l}\text { - Perceber se as } \\
\text { práticas realizadas } \\
\text { por outros } \\
\text { professores } \\
\text { influenciam a } \\
\text { autoria docente } \\
\text { com os recursos }\end{array}$ & $\begin{array}{l}\text { 10) Que impactos a autoria de recursos pelos seus pares } \\
\text { tem nas práticas de autoria de RED? } \\
\text { (fatores que fomenta a autoria) }\end{array}$ \\
\hline $\begin{array}{l}\text { Verificar se a } \\
\text { utilização de RED } \\
\text { tem alguma } \\
\text { implicação ao nível } \\
\text { da inovação das } \\
\text { práticas } \\
\text { pedagógicas }\end{array}$ & $\begin{array}{l}\text { 11) Em que medida o uso dos RED estimula inovação das } \\
\text { suas práticas metodológicas? } \\
\text { - Relação entre a utilização de RED e a inovação } \\
\text { pedagógica. }\end{array}$ \\
\hline \multicolumn{2}{|c|}{ Bloco D - Validação da entrevista } \\
\hline $\begin{array}{l}\text { - Verificar se } \\
\text { existem sugestões } \\
\text { dos participantes } \\
\text { acerca do tema } \\
\text { e/ou questões } \\
\text { discutidos na } \\
\text { entrevista }\end{array}$ & $\begin{array}{l}\text { 12) Há ainda alguma aspecto que queiram acrescentar? } \\
\text { Houve algum assunto que não foi abordado e gostariam } \\
\text { de discutir? } \\
\text { - Sugestões sobre o grupo focal ou informações que não } \\
\text { foram abordadas }\end{array}$ \\
\hline $\begin{array}{ll}\text { Validação } & \text { da } \\
\text { entrevista } & \end{array}$ & $\begin{array}{l}\text { - Coadjuvante lê as notas que foi registando de maneira } \\
\text { a que os entrevistados possam indicar que o expresso } \\
\text { reflete o discutido e acrescentar outros aspetos, se } \\
\text { considerarem relevante. } \\
\text { - Finalizar o grupo focal. }\end{array}$ \\
\hline
\end{tabular}




\section{Apêndice VI - Roteiro para o Grupo Focal On-line após avaliação}

1) Apresentação da mediadora, observadora e do GFO. Explicar que o grupo focal será gravado e que a observadora tomará notas. Esclarecer questões de anonimato da pesquisa

2) Pedir para que os participantes façam uma breve apresentação

3) Apresentar as imagens e vídeo e solicitar que o participante escolha a situação que mais se aproxima de sua concepção de autoria e pedir que justifique.

4) Pedir para que os participantes escrevam uma definição de autoria a partir da situação escolhida.

5) Existe alguma relação entre o conceito de autoria com a criação de RED?

6) Em qual atividade com RED você foi mais criativo? Qual atividade com RED você cria com mais frequência? (essa criação é sozinha, com outros professores, com alunos?) (as criações são compartilhadas? Como?)

7) Ter competências digitais ajuda na autoria de RED? Quais competências tecnológicas são mais utilizadas na criação dos recursos?

8) O que te levou a criar RED? (desenvolvimento profissional ou motivação)

9) Leitura das notas de observação e validação do grupo focal pelos participantes. 


\section{Apêndice VII - Adaptação do Roteiro para Entrevista}

1. Apresentação da entrevistadora e explicação de que a entrevista será gravada com garantia de anonimato.

2. Apresentar as imagens e solicitar que o participante escolha a situação que mais se aproxima da concepção de autoria e pedir para que justifique.

3. Pedir para que o participante defina autoria a partir da imagem escolhida

4. Você percebe essa autoria em sua prática docente? Quando você é um professor autor?

(caminho profissional ou pessoal para se tornar um professor autor)

5. Existem relação dessa concepção de autoria com a criação de recursos educacionais digitais?

6. Que tipo de atividade com recursos digitais você mais cria no seu contexto de trabalho?

Qual atividade com RED você foi mais criativo?

(essa criação é sozinha ou com outros professores? Já criou RED com os alunos? Como foi a experiência de aprendizado ao utilizar esses RED? (infraestrutura de sala de aula para o trabalho com os RED)

7. As criações de RED são compartilhadas de alguma forma? Por que você compartilha? Como?

8. Ter competências digitais ajuda na autoria de RED? Quais competências são mais utilizadas por você na criação dos recursos?

9. O que te levou a criar RED?

(desenvolvimento profissional ou motivação)

(Gestão da escola)

(apoio de outros professores)

(Já utilizava alguma tecnologia em sua docência?)

10. Houve algum tipo de mudança em sua prática pedagógica ou na dinâmica da sala de aula após a utilização de RED em seu contexto profissional? (houve algum tipo de inovação?)

11. Existe algum aspecto que queira acrescentar entre os assuntos que foram abordados? 